\title{
Ground-Water Contribution to Dose From Past Hanford Operations
}

\author{
M. D. Freshley \\ P. D. Thorne
}

August 1992
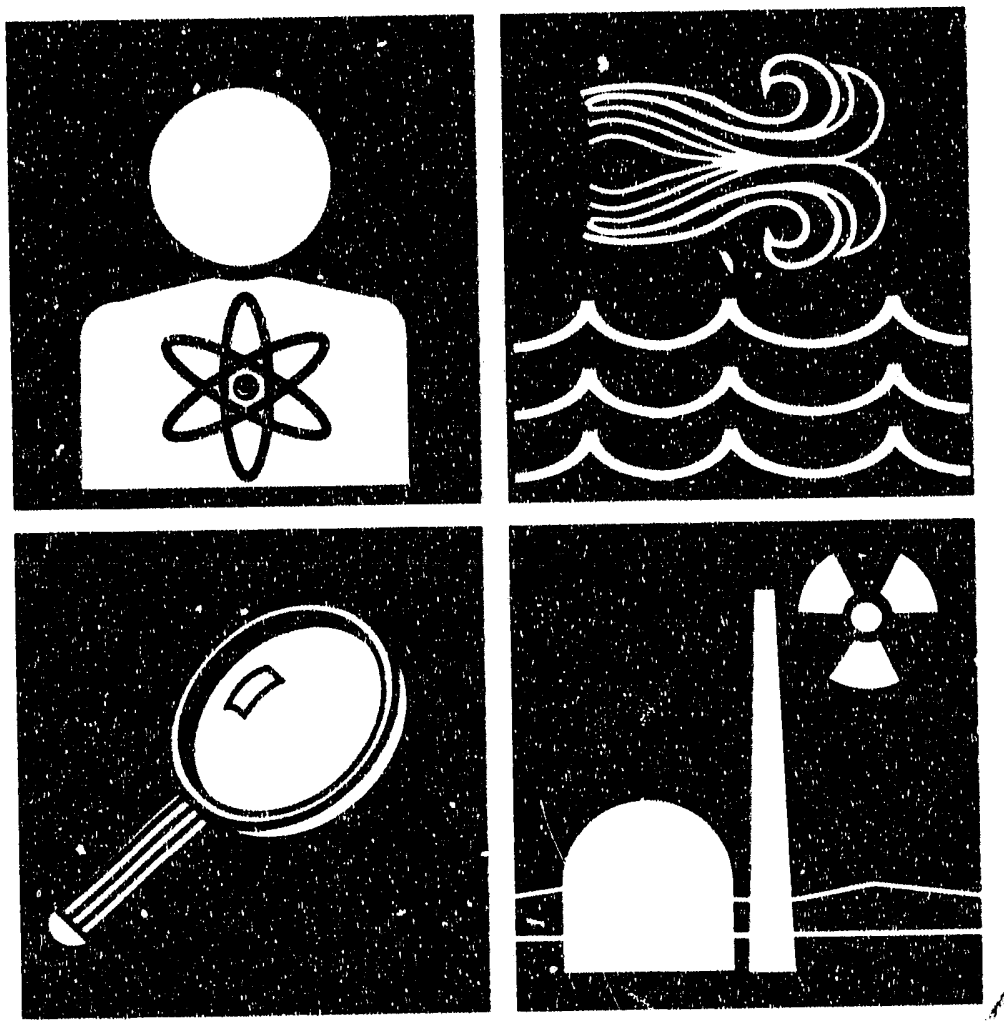

Prepared for the Technical Steering Panel and the Centers for Disease Control under Contract Number 18620 


\section{LEGAL NOTICE}

This report was prepared by Battelle as an account of sponsored research activities. Neither Sponsor nor Battelle nor any person acting on behalf of either:

MAKES ANY WARRANTY OR REPRESENTATION, EXPRESS OR IMPLIED, with respect to the accuracy, completeness, or usefulness of the intormation contained in this report, or that the use of any information, apparatus, process, or composition disclosed in this repon may nor infringe privately owned rights; or

Assumes any liabilities with respect to the use of, or damages resulting from the use of, any information, apparatus " process, or composition disclosed in this report.

Reference herein to any specific commercial product, process, or service by trade name, trademark, manufacturer, or otherwise, does not necessarily constitute or imply endorsoment, recommendation, or favoring by Sponsor or Battelle.

Printed in the United States of America

Availuble to DOE and DOE contractors from the

Office of Scientific and rechnical Information, P.O. Box 62, Oak Ridge, TN 37831; prices available from (615) 576-8401. FTS 626-6401

Available to the public from the National Technical Information Service,

U.S. Department of Commerce, 5285 Port Royal Rd., Springrield, VA 22161. 
PNWD-1974-HEDR

DE92 019889

GROUND-WATER CONTRIBUTION TO DOSE

FROM PAST HANFORD OPERATIONS

Hanford Environmental Dose

Reconstruction Project

M. D. Freshley

P. D. Thorne

August 1992

Prepared for

the Technical Steering Pane1

and the Centers for Disease Control

under Contract Number 18620

Battelle

Pacific Northwest Laboratories

Richland, Washington 99352
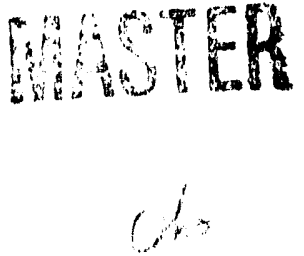

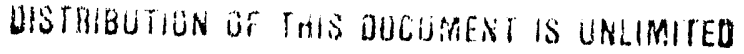


GROUND-WATER CONTRIBUTION TO DOSE

FROM PAST HANFORD OPERATIONS

This document has been reviewed and approved by the Technical Steering Pane 1
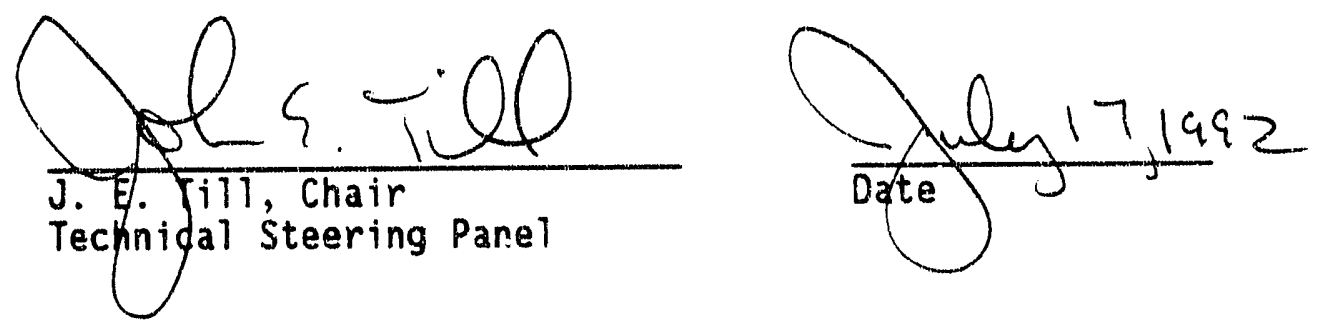


\section{PREFACE}

The Hanford Environmental Dose Reconstruction (HEDR) Project was undertaken in 1987 at the recommendation of the Hanford Health Effects Review (HHER) Panel. The HHER Panel had been formed to consider the potential health implications of historic releases of radioactive materials from the Hanford Site.

The Centers for Disease Control (CDC) provides funding for the project; Battelle, Pacific Northwest Laboratories (Battelle) performs the research. The HEDR research is directed by an independent Technical Steering Panel (TSP). The 18-member panel consists of experts in the various technical fields of importance to project work and representatives of the states of Washington, Oregon, and Idaho; Native American tribes; and the public.

The project objective is to estimate radiation cioses to individuals and population groups from exposure to historical radioactive emissions from the Hanford Site. This document summarizes the contribution to dose of radionuclides discharged to the ground water at the Hanford Site. Ground water is one of the transport pathways through which radionuclide emissions at the Hanford site reached the public at offsite locations. The other transport pathways include the atmosphere, where iodine-131 and other radionuclides were released from chemical separations at the Site, and the Columbia River, where effluent from the reactors was discharged.

This document is an updated version of the previous version dated March 1992. Changes from the March 1992 version are shown in italics. The document number for the March 1992 version was PNL-7870 HEDR; the current (August 1992) version is numbered PNWD-1974 HEDR. The report numbering system changed from the "PNL" designator (when Battelle's HEDR work was under contract to the U.S. Department of Energy) to the "PNWD" designator in June 1992 (when the work came under contract to the Centers for Disease Control). Appendix $E$ is a record of the Technical Steering Panel's (TSP) corments and Battelle's responses. In the report text, the comment number(s) appears in the left margin next to the paragraph in which the corresponding TSP comment( $s)$ is 
A. Release estimates

3. Monitoring ciata

C. Models

1. Milk model

2. Exposed fruits/vegetables model

3. Columbia River model

4. Air, environmental dose models

5. Sensitivity/uncertainty analysis, verification validation

D. Dose estimates

1. HTDS doses

2. Individual doses

3. Native American doses

Ba - Planned work

- Contiruing work

- - Wort contingent on TSP decision

7 - Milestone

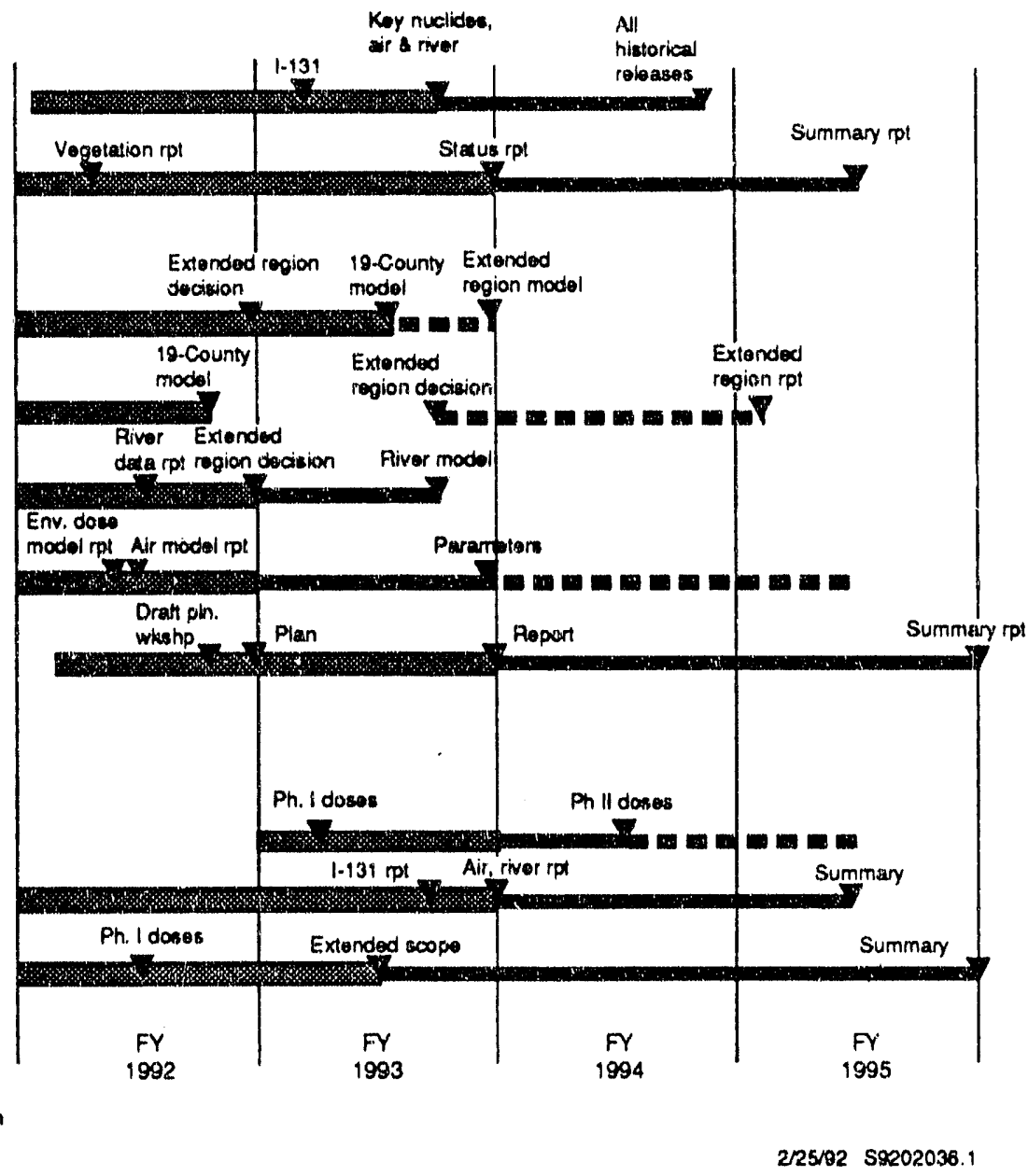

EIGURE P.1. HEDR Schedule Overview, FY 1992 - 1995

addressed. Any text that has been changed is shown in italics. Also, some text has been changed to correct errors or to clarify.

The TSP has reviewed and approved this document, thus, evaluation of the ground-water transport pathway is considered complete. As shown in Figure P.1, however, the HEDR Project is scheduled to continue through FY 1995. The technical work required to develop models and databases to estimate radiation doses to individuals and special population groups for key radionuclides and major exposure pathways will be completed by the end of FY 1993. For the air-transport pathway, these models and databases will be concentrated on a 19-county area around the Hanford Site from 1944 through 1991. Radiation doses from the atmospheric pathway will be used in the 
Hanford Thyroid Disease Study (HTDS) being conducted by the Fred Hutchinson Cancer Research Center to determine whether thyroid disease increased as a result of Hanford radiation exposures. Models and databases are also being developed for the Columbia River transport and exposure pathway. Radiation doses for the river pathway will be based on monitoring data, modeling results, or a combination of the two. Source-term data; demographics; and food production, distribution, and consumption estimates will be developed to support dose estimates for both the atmospheric and Columbia River transport pathways.

Two points about the ground-water pathway study need to be emphasized: 1) it is retrospective and 2 ) it is concerned only with radiological contamination. This study is retrospective in that HEDR staff reviewed existing literature to estimate radiation doses that populations or individuals could have received in the past from radionuclides in contaminated ground water migrating off the Hanford Site. A considerable amount of contamination that may result in future radiation doses currently exists in the ground water and the unsaturated zone (between the ground surface and ground water) at the site. With respect to the second point, the concern is with impacts only from radionuclides in ground water at the Hanford Site. A considerable amount of chemical contamination is also documented to be present in the ground water and the unsaturated zone at the Hanford Site (Jaquish and Bryce 1990).

There is a distinction between the work conducted on the HEDR Project to address ground water and the monitoring and characterization work currently being conducted to address compliance with the Resource Conservation and Recovery Act (RCRA); the Comprehensive Environmental Response, Compensation, and Liability Act (CERCLA); the Superfund Amendments and Reauthorization Act (SARA); and DOE orders. These compliance activities are being conducted to assess the risks of future exposures to radionuclides and hazardous chemicals currently in the soil and ground water at the Hanford Site. On the other hand, the HEDR Project is concerned only with exposure from radionuclides and with exposures that may have already occurred. 


\section{ABSTRACT}

The Hanford Environmental Dose Reconstruction (HEDR) Project is being conducted to estimate radiation doses that populations and individuals could have received from Hanford Site operations from 1944 to the present. Four possible pathways by which radionuclides migrating in ground water on the Hanford Site could have reached the public have been identified: 1) through contaminated ground water migrating to the Columbia River; 2) through wells on or adjacent to the Hanford Site; 3 ) through wells next to the Columbia River downstream of Hanford that draw some or all of their water from the river (riparian wells); and 4) through atmosp'eric deposition resulting in contamination of a small watershed that, in turn, results in contamination of a shallow well or spring by transport in the ground water. These four pathways make up the "ground-water pathway," which is the subject of this study.

Assessment of the ground-water pathway was performed by 1) reviewing the existing extensive literature on ground water and ground-water monitoring at Hanford and 2) performing calculations to estimate radionuclide concentrations where no monitoring data were collected. Radiation doses that would result from exposure to these radionuclides were calculated.

This study is retrospective in that only radiation doses that populations or individuals may have received were considered. The question addressed is to what extent the ground-water pathway might have contributed to past radiation doses. Potential future radiation doses are being addressed by other studies at the Hanford Site.

11-13 Estimated doses for the ground-water pathway are sma17: 0.02 milliram per year (mrem/y) from discharge of contaminated ground water to the Columbia River; $1 \mathrm{mrem} / \mathrm{y}$ effective dose equivalent from Hanford Site wells; $11 \mathrm{mrem} / \mathrm{y}$ effective dose equivalent from riparian wells; and $15 \mathrm{mrem} / \mathrm{y}$ effective dose equivalent from a hypothetical calculation for the watershed pathway. These estimated doses are small compared to the TSP dose decision levels of $100 \mathrm{mrem} / \mathrm{y}$ effective dose equivalent for an adult and $50 \mathrm{mrem} / \mathrm{y}$ effective dose 
equivalent for an infant. (a) Therefore, the recommendation is that no further work on the ground-water pathway be performed, other than tracking ongoing studies related to ground water at the Hanford Site.

(a) Shleien, B. 1992. "Scoping Document for Determination of Temporal and Geographic Domains for the HEDR Project." Prepared for the Technical Steering Panel, approved by the Panel in April 1992. Washington State Department of Ecology, 1-800-545-5581. 


\section{SUMMARY}

Staff on the Hanford Environmental Dose Reconstruction (HEDR) Project are studying releases of radionuclides to the air, to the Columbia River, and to ground water, as well as transport of these radionuclides to locations where populations and/or individuals could have been exposed. The Technical Steering Panel (TSP) that directs the HEDR Project has identified four possible pathways by which radionuclides originating in ground water on the Hanford Site could have reached the public during the time period 1944 to the present:

1. drinking water contaminated with radionuclides that migrated offsite either by ground-water flow into the Columbia River or, possibly, by ground-water flow to wells on the Franklin County side of the river

2. drinking water from wells on or adjacent to the Hanford Site contaminated by radionuclides that migrated away from disposal sources at the Site

3. drinking water from riparian wells (those next to the river) contaminated with radionuclides from Hanford operations

4. drinking ground water from a shallow well or spring contaminated by radionuclides transported through the atmosphere and deposited on a small watershed (stream drainage).

These four pathways were investigated in the ground-water transport subtask of the Environmental Transport Task. Specifically, the objective of the subtask was to assess the extent to which the ground-water pathway contributed to radiation doses that populations or individuals may have received from past operations at the Hanford Site.

\section{APPROACH}

The technical approach to addressing the ground-water pathway was to review and summarize literature pertaining to ground water and ground-water monitoring both on and off the Hanford Site. Where no monitoring data were available, calculations were used to estimate concentrations of radionuclides in ground water. The monitoring data and calculation results were used to estimate radiation doses from exposure to ground-water contamination. 
The first ground-water pathway, offsite migration, was addressed by reviewing and summarizing results of ground-water monitoring both on and off the Hanford Site. In addition, calculations were performed to estimate radionuclide concentrations in the Columbia River resulting from ground-water discharge near the Hanford townsite where the main part of the tritium plume discharges to the river. As part of this pathway evaluation, the extensive ground-water monitoring data reported for the Hanford Site were summarized. All ground-water monitoring data were considered, but more information exists for gross beta, tritium, and iodine-129 than for other specific radionuclides. Therefore, more emphasis is placed on gross beta, tritium, and iodine-129 than on other radionuclides. The changes in interpretations of the monitoring results are described and related to improvements in monitoring technologies.

The second ground-water pathway, Hanford Site wells supplying drinking water, was addressed by reviewing monitoring documents published by the Hanford Environmental Health Foundation and other Hanford Site contractors, as well as publications by the Washington State Department of Ecology and the Washington State Department of Social and Health Services. The third pathway, riparian wells, was addressed by identifying the factors that impact radionuclide concentrations in riparian wells and extrapolating radiation doses from previous estimates for Richland and Kennewick water supplies. The radiation doses for Richland are based on direct use of Columbia River water. The fourth pathway, atmospheric deposition resulting in contamination of a small watershed that, in turn, results in contamination of a shallow' well or spring by transport in the ground water, was addressed by hypothetical calculations.

Dose estimates for representative radionuclide concentrations in the ground water are provided in this report. Dose estimates were either taken from published literature or were calculated where published estimates were not available. To place the dose estimates in perspective, they are compared with the TSP dose decision levels specified in Shleien 1992. (a)

(a) Shleien, B. 1992. "Scoping Document for Determination of Temporal and Geographic Domains for the HEDR Project." Prepared for the Technical Steering Panel, approved by the Panel in ApriT 1992. Washington State Department of Ecology, 1-800-545-5581. 


\section{RESULTS}

The review of literature pertaining to the offsite migration pathway revealed that a considerable amount of information has been generated on the distribution of radionuclides in ground water at the Hanford Site. Changes in monitoring technologies have improved the quality of information available and have changed interpretations of the ground-water contamination data. For example, during the early 1960s when tritium was found to be a product of Hanford Site operations, initial sampling and analysis of ground water in the unconfined aquifer demonstrated that tritium had reached the Columbia River in detectable quantities (Brown and Haney 1964). However, additional monitoring wells and improved analytical techniques suggested that the earlier analyses and interpretations of the data were not correct. Therefore, a smaller plume of tritium was interpreted to be in the ground water, leading to the conclusion that the contamination had not jec reached the river (Essig 1968).

A conceptual diagram of the primary exposure routes for the ground-water pathway is illustrated in Figure 5.1. Dose estimates for. the four groundwater pathways are summarized in Table S.1. A range in dose is presented for each pathway along with the radionuclides that contributed to the dose calculation and the years for which the estimates apply. Radiation dose estimated for the offsite migration pathway was $0.02 \mathrm{millirem}$ per year (mrem/y) effective dose equivalent (at the Richland pumphouse during 1989 and 1990) from discharge of contaminated Hanford Site ground water to the Columbia River (Jaquish and Bryce 1990; Woodruff et al. 1991). The dose from migration of contaminated ground water offsite to wells in Franklin County on the east side of the river was negligible (WDSHS 1988). The dose estimate of $0.02 \mathrm{mrem} / \mathrm{y}$ includes contributions from tritium, technetium-99, and iodine-129. The year 1989 was used to estimate the river concentrations resulting from the groundwater discharge because that is when the highest concentrations of tritium in ground water had reached the river; the contributions during previous years would be less. 


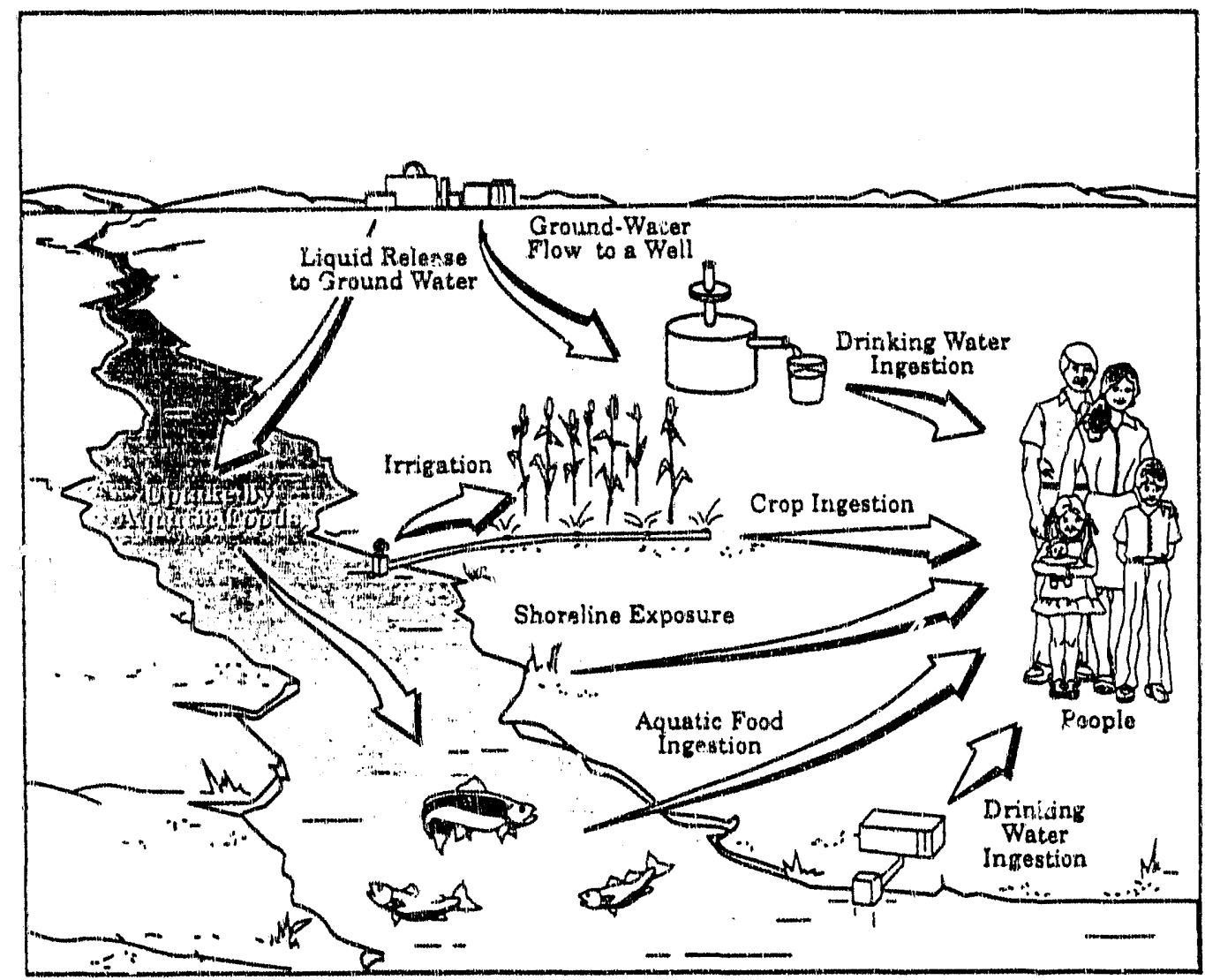

EIGURE S.d Primary Ground-Water Exposure Pathways

IABLE S.1. Summary of Dose Estimates for the Four Ground-Water Pathways

Pathway Description

17-20 Ofisite Migration to Columbia Aiver

Offsite Migration to Wells in Franklin County

Hantord Site Drinking-Weter Wolls

Riparian Wells Downstream from Hanford

Armospheric Transport, Deposition, and Shallow Ground-Water Transport to a Wall or Spring
Effective Dose

Equivalont (mrem/v)

0.02

$\sim 0$

$0.0006 \cdot 1$

$2-14$

$1-15$

Radionuclides

Tritlum,

Technetium-99,

lodine-129

Uranium, lodine-129

lodino-129, Tritium 1977

Phosphorous-32, 1964

Zinc-65, Arsenic-76, through 1966

Neptunium-239,

Sodlum-24,

Manganese-56

Ruthenium-126
All years

Year

1989,1990

1945 
The expected average concentration of tritium in the Columbia River during 1989 from ground-water discharge was estimated with calculations to be 6 oicocuries per liter ( $\mathrm{pCi} / \mathrm{L}$ ), with a range of $1-11 \mathrm{pCi} / \mathrm{L}$. This calculated ioncentration was compared with $66 \mathrm{pCi} / \mathrm{L}$, the measured difference between average roncentrations upstream of the Hanford Site (at Priest Rapids Dam) and downstream (at the Richland pumphouse) during 1989. The effluent discharge from the 100-N Area during 1990 was estimated to be 38 curies (Ci) of tritium and approximately $2 \mathrm{Ci}$ of strontium-90 (Woodruff et al. 1991). Similar estimates were not published in the 1989 annual report by Jaquish and Bryce (1990). Assuming that discharge of these radionuclides to the river was the same during 1989, the resulting tritium concentration in the river from this discharge was less than $1 \mathrm{pCi} / \mathrm{L}$. "Whis cuntribution does not significantily improve the comparison between the calculated and the measured concentrations in the river from ground-water discharge. However, both the calculations and the measurements have uncertainties that have not been quantified, and these uncertainices affect this comparison. Quantifying some of the uncertainties due to the assumptions: such as the representativeness of river concentration measurements at the Richland pumphouse, is outside the scope of the HEDR Project.

Monitoring results for wells in Frankl in County show that concentrations of iodine-129 provide doses in the range of $2 \times 10^{-7}$ to $2 \times 10^{-5} \mathrm{mrem} / \mathrm{yr}$ effective dose equivalent $\left(7 \times 10^{-4}\right.$ to $7 \times 10^{-6} \mathrm{mrem} / \mathrm{y}$ to the thyroid), well below the $100 \mathrm{mrem} / \mathrm{y}$ effective dose equivalent for an adult and $50 \mathrm{mrem} / \mathrm{y}$ effective dose equivalent for an infant specified by the TSP. (a) Uranium found in Franklin County wells has been determined to bo of natural origin and not from the Hanford Site (WDSHS 1988). Therefore, the dose from offsite migration of Hanford Site radionuclides to wells in Franklin County can be considered negligible.

(a) Shleien, 8. 1992. "Scoping Document for Determination of Temporal and Geographic Domains for the HEDR rroject." Prepared for the Technical Steering Panel, approved by the Panel in Apri7 1992. Washington State Department of Ecology, 1-800-545-5581. 
The radiation dose for the Hanford Site well pathway was estimated based on the dose from tritium and iodine-129 in the well water wsed by people at the Fast Flux Test Facility (FFTF) Visitor Center, which is open to the public. The dose from tritium at the FFTF, highest during 1977, resulted in 1 mrem annual dose to workers based on drinking water during a 40-hour work week (Maas 1978). The impacts to occasional visitors would be far less than the calculated impacts to workers. As an exampie, Woodruff et al. (1991) reported that, based on monitoring data during 1990, the potential dose received by a member or the public from drinking 1 liter ( $L$ ) of water during a visit to the FFTF Visitor Center was $0.0006 \mathrm{mrem} / \mathrm{y}$ effective dose equivalent. The maximum organ dose (thyroid) was calculated to be $0.0007 \mathrm{mrem} / \mathrm{y}$.

The potential radiation doses received from using contaminated ground water from riparian wells were difficult to quantify besause only limited monitoring data are available. The possible dose from riparian wells during 1964 through 1966 was estimaiced from Phase I of the HEDR Project (PNL 1991b) to be 2-14 $\mathrm{mrem} / \mathrm{y}$ effective dose equivalent, based on the dose from direct use of water from the Columbia River at Richland. Kennewick is the nearest municipality downstream of the Hanford Sit': that is supplied by riparian wells and has the only water supply from a riparian well known to have been monitored for radionuclides. The average radiation dose from drinking water from the Kennewick water supply was $3 \mathrm{mrem} / \mathrm{y}$ effective dose equivalent, estimated for 1964 through 1966.

The dose estimated with calculations for the watershed pathway was 1-15 mrem/y effective dose equivalent (during 1945) for a range of passible parameters used. Ruthenium-106 was the only radionuclide predicted to reach the hypothetical well or spring through the shallow ground-water sys:?m in concentrations close to its drinking-water limit (30 pCi/L [EPA 1976]), which was used to screen the list of radionuclides.

\section{CONCLUSIONS AND RECOMMENDATION}

Analyses of the ground-water pathways led to the conclusions that ground water did not make a significant contribution to dose during the study period, 1944 to the present. The dose estimates are small compared with the TSP dose 
decision level of $100 \mathrm{mrem} / \mathrm{y}$ effective dose equivalent for an adult and $50 \mathrm{mrem} / \mathrm{y}$ effective dose equivalent for an infant. ${ }^{\text {(a) }}$ The population affected by discharge of ground-water contamination to the Columbia River was primarily residents of Richland, Kennewick, and Pasco. These communities accounted for $80 \%$ of the use of treated Columbia River water between Hanford and the river mouth during 1964 through 1966.

24,25 Dose estimates from published literature and calculations performed to address the overall ground-water pathway contain uncertaintias, not all of which have been quantified. However, ground water made only a small contribution to radiation dose.

The TSP has reviewed and approved this document, thus, evaluation of the ground-water transport pathway is considered complete. The recommendation from the results of this study is that further work on the ground-water pathway be 1 imited to tracking the resu:ts of ongoing studies related to ground water at the Hanford Site.

(a) Shieien, B. 1992. "Scoping Document for Determination of Temporal and Geographic Domains for the HEDR Project." Prepared for the Technical steering Panel, approved by the Pariel in Apri7 1992. Washington State Department of Ecology, 1-800-545-5581. 
PREFACE ...............................

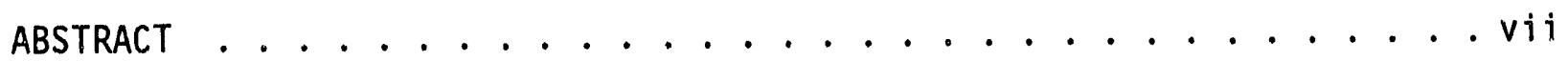
SUMMARY ........................... ix

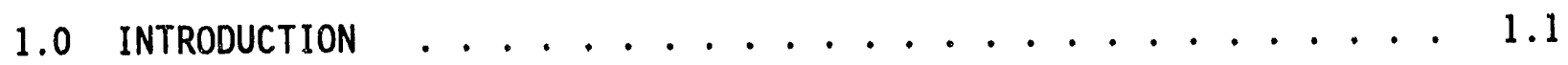

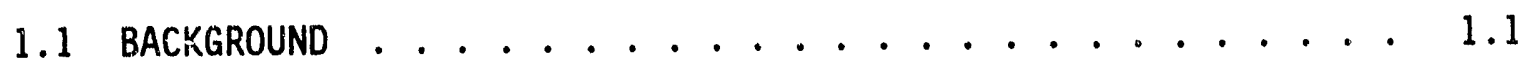

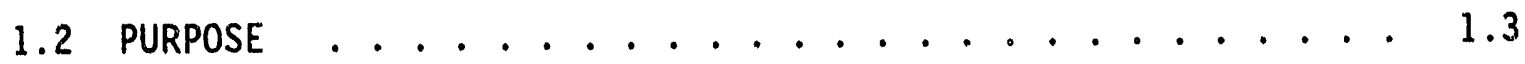

1.3 SCUPE $\ldots \ldots \ldots \ldots \ldots \ldots$

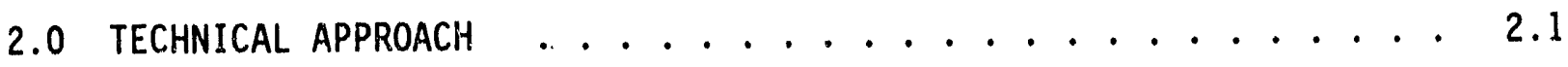

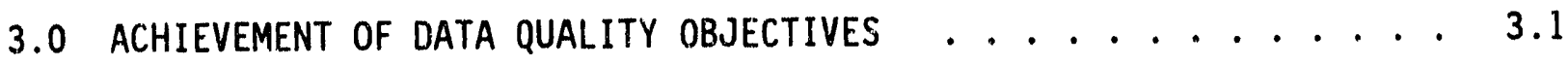

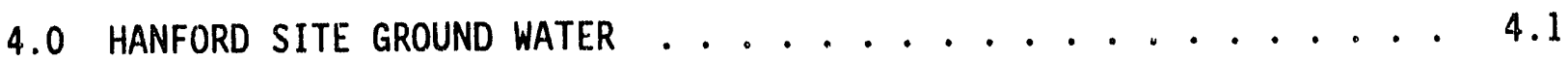

4.1 MOVEMENT OF GROUND WATER AT THE HANFORD SITE $\ldots \ldots \ldots$

4.2 SOURCES OF RADIOliUCLIDES IN HANFORD SITE GROUND WATER $\ldots 4.7$

4.2 .1 Contamination from Solid-Waste Disposal . . . . 4.8

4.2.2 Contamination from Liquid-Waste Disposal . . . . 4.8

4.3 CLASSIFICATIONS OF RADIOACTIVE WASTE . . . . . . 4.13

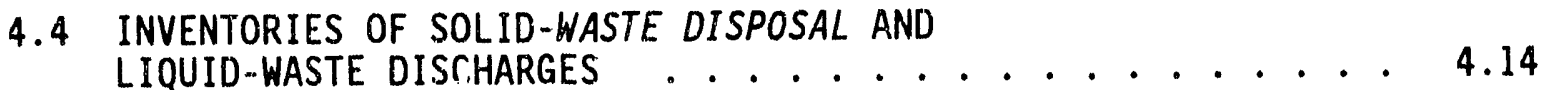

4.5 TFSTS FOR GROUND DISPOSAL OF WASTES . . . . . . . 4.16

4.6 INFLUENCES ON RADIONUCLIDE MOVEMENT AT HANFORD . . . . 4.18

4.6.1 Natural Recharge ............ 4.18

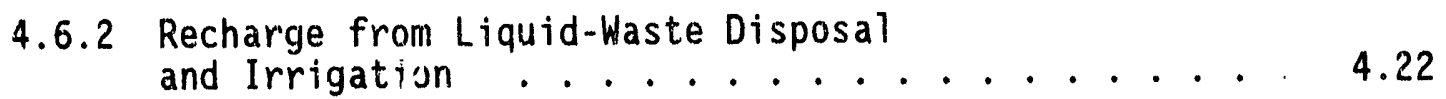

4.6.3 Distribution of Aquifer Properties ...... 4.24

4.6 .4 Flori-Path Variation ............ 4.27

4.6.5 Geochemical Properties . . . . . . . . 4.29 
5.0 GROUND-WATER MONITORING ON AND UFF THE HANFORD SITE $\ldots \ldots \ldots$

5.1 SCOPE OF MONITORING PROGRAM ................. 5.1

5.2 DESCRIPTION OF MONITORING TECHNOLOGY ......... 5.2

5.2 .1 Monitoring Wells ............ 5.2

5.2 .2 Sample Collection .............. 5.5

5.2.3 Sample Analysis . . . . . . . . . . 5.6

5.2 .4 Other Measurement Devices . . . . . . . 5.11

5.2.5 Interpretation of Results and . . . . . . . . . 5.14
Supporting Studies ...

6.0 OFFSITE GROUND-WATER MIGRATION PATHWAY .............. 6.1

6.1 RADIONUCLIDE MOVEMENT ON AND OFF THE HANFORD SITE $\ldots \ldots .6 .3$

6.1.1 Radionuclide Movement from the 200 Areas . . . . 6.4

6.1.2 Radionuclide Movement from the 100 Areas . . . . 6.64

6.1.3 Radionuclide Movement from the 300 Area . . . . . 6.66

6.2 RIVER CONCENTRATIONS RESULTING FROM GROUND-WATER

DISCHARGE ....................... 6.67

6.3 RIVER BANK SPRING MONITORING . . . . . . . . . . 6.72

6.3.1 Description of River Bank Spring Monitoring . . . 6 6.73

6.3 .2 Summary of Results ............. 6.73

6.4 COLUMBIA RIVER MONITORING . . . . . . . . . . . . 6.74

6.4.1 Description of River Monitoring . . . . . . 6.74

6.4 .2 Summary of Results . . . . . . . . . 6.75

6.5 GROUND WATER IN FRANKLIN COUNTY . . . . . . . . 6.77

6.5.1 Effects of Irrigation ........... 6.78

6.5 .2 Monitoring Results ............ 6.79

6.6 RADIATION DOSES FROM OFFSITE MIGRATION . . . . . . 6.82 
7.0 HANFORD SITE DRINKING-WATER WELL PATHWAY . . . . . . . 7.1

7.1 DRINKING-WATER SYSTEMS ON AND ADJACENT TO THE HANFORD SITE

7.2 SAMPLING AND ANALYSIS . . . . . . . . 7.3

7.3 MONITORING RESULTS . . . . . . . . . . . 7.5

8.0 RIPARIAN WELL PATHWAY . . . . . . . . . . . 8.1

8.1 FACTORS AFFECTING IMPACT FROM RIPARIAN WELLS . . . . . 8.1

8.1.1 Concentration of Radionuclides in River Water . . 8 8.2

8.1.2 Percentage of River Water from a Riparian Wel1 . . 8.3

8.1.3 Effects of Filtration, Sorption, and Radioactive
Decay . . . . . . . . . 8.4

8.1.4 Use of Water from Riparian Wells . . . . . 8.5

8.2 RADIATION DOSES FROM USE OF RIPARIAN WELLS . . . . . 8.6

9.0 WATERSHED PATHWAY . . . . . . . . . . . . . . . . 9.1

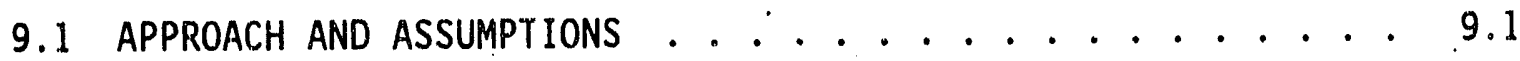

9.2 WATERSHED DEPOSITION CALCULATIONS $\ldots \ldots . \ldots . \ldots . . . \ldots$

9.3 RADIATION DOSES FROM WATERSHED DEPOSITION CALCULATIONS • . 9.5 10.0 CONCLUSIONS AND RECOMMENDATION ................ 10.1

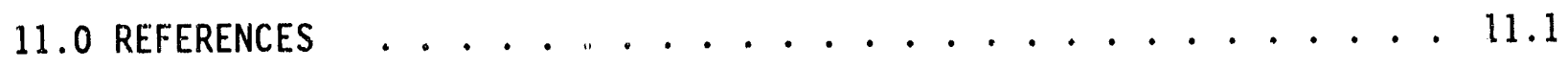
APPENDIX A - TSP DIRECTIVE 88-4 . . . . . . . . . . . A.. APPENDIX B - SUMMARY OF SANITARY-WATER SYSTEMS AT THE HANFORD $\ldots \ldots$. . . . . . . . . . . . . . . . APPENDIX $C$ - COMMUNITIES WHOSE DRINKING WATER MAY HAVE COME FROM
PIPARIAN WELLS DOWNSTREAM OF HANFORD $\ldots \ldots \ldots$ APPENDIX D - GLOSSARY . . . . . . . . . . . . . . D. . . APPENDIX E - SUMMARY OF THE TECHNICAL STFERING PANEL'S COMMENTS AND BATTELLE'S RESPONSES 


\section{FIGURES}

P.1 HEDR Schedule Uverview, FY 1992-1995 ........... iv

S.1 Primary Ground-Water Exposure Pathways . . . . . . . . . . . xii

1.1 Location of the Hanford Site in Washington State . . . . . 1.2

4.1 Schematic Geologic Cross Section for the Hanford Site . . . . 4 4.2

4.2 Water Table Elevations at the Hanford Site for June 1989 . . . 4.3

4.3 Water Table Elevations at the Hanford Site for 1944 . . . . . . 4.4

4.4 Hydraulic-Head Map of the Rattlesnake Ridge Confired Aquifer Within the Hanford Site ............... 4.6

4.5 Schematic Cross Section of a Typical Solid-Waste Trench . . . . 4.8

4.6 Schematic Cross Section of a Typical Disposal Pond . . . . . 4.10

4.7 Schematic Diagram of a Typical "Timbered-Box" Crib . . . . . 4.11

4.8 Distribution of Areal Recharge to the Unconfined Aquifer . . . 4.21

4.9 Water-Leve1 History (Hydrograph) for Well 699-45-42 . . . . 4.23

4.10 Hydraulic-Head Distribution in the Uppermost Confined Aquifer in $1966 \ldots . . . . . . . . . .24 .25$

4.11 Water-Level Distributions for the Unconfined Aquifer in Benton and Frankl in Counties During 1989 . . . . . 4 4.26

4.12 Distribution of Transmissivity in the Unconfined Aquifer Resulting from the Inverse Calibration ........ 4.28

5.1 Distribution of Ground-Water Monitoring Wells During 1989 . . . 5.7

5.2 Ground Water Temperatures in the Unconfined Aquifer During 1962................... . 5.14

6.1 Concentration History for Tritium Measured in Well 699-40-1 . . 6.3

6.2 Ground-Water and Surface-Water Sampling Locations During 1949... . . . . . . . . . . 6.8

6.3 Approximate Extent of Known Ground-Water Contamination from the 200-East Area During January 1956 . . . . . . . . . 6.11 
6.4 Approximate Extent of Known Ground-Water Contamination from the 200-West Area During January 1956... . . . . . . . 6.12

6.5 Approximate Extent of Known Ground-Water Contamination from the 200-East Area During April 1956............ . . 6.13

6.6 Approximate Extent of Known Ground-Water Contamination from the 200-West Area During April 1956........... . 6.14

6.7 Approximate Extent of Known Ground-Water Contamination from the 200-East and 200-West Areas During July, August, and September 1956

6.8 Approximate Extent of Known Ground-Water Contamination from che 200-East and 200-West Areas During January, February, and March 1957

6.9 Approximate Extent of Known Ground-Water Contamination from the 200-East Area During April, May, and June 1957 . . . . . . 6.17

6.10 Approximate Extent of Known Ground-Water Contamination from the 200-West Area During Apri1, May, and June 1957 . . . . 6.18

6.11 Approximate Extent of Known Ground-Water Contamination from the 200-East and 200-West Areas During October, November, and December 1957 .................... 6. . . . . . . . . . . .

6.12 Approximate Extent of Known Ground-Water Contamination from the 200-East and 200-West Areas During January, February, and March 1958 . . . . . . . . . . . . . . . . . 6.21

6.13 Approximate Extent of Known Ground-Water Contamination from the 200-East and 200-West Areas During Octobel", November, and December 1958 . . . . . . . . . . . . . . . . 6.22

6.14 Distribution of Kriown Ground-Water Contamination Based on Gross Beta Measurements for September 1959 . . . . . . . 6.23

6.15 Distribution of Known Ground-Water Contamination Based on Gross Beta Measurements for October, November, and December 1959 ..................... 6.24

6.16 Distribution of Average Gross Beta Concentrations in the Unconfined Aquifer During July Through December 1962 . . . . . 6.26

6.17 Distribution of Average Gross Beta Concentrations in the Unconfined Aquifer During January Through June 1963 . . . . . . 6.27

6.18 Distribution of Average Gross Beta Concentrations in the Unconfined Aquifer During July Through December 1963 . . . . 6.28

6.19 Distribution of Average Gross Beta Concentrations in the 
Unconfined Aquifer During January Through December 1964 . . . . 6.29

6.20 Distribution of Average Gross Beta Concentrations in the Unconfined Aquifer During July Through December 1965 ..... 6.30

6.21 Response of Downgradient Monitoring Wells to Gross Beta Emitters Discharged to the 216-A-10 Crib ......... 6.31

6.22 Distribution of Average Gross Beta Concentrations in the Unconfined Aquifer During 1974 ............ 6.32

6.23 Distribution of Average Tritium Concentrations in the Unconfined Aquifer During 1989 . . . . . . . . 6.35

6.24 Distribution of Average Tritium Concentrations in the Unconfined Aquifer During January Through June 1962 . . . . 6.37

6.25 Distribution of Average Tritium Concentrations in the Unconfined Aquifer During July Through December 1962 . . . . . 6.38

6.26 Distribution of Average Tritium Concentrations in the Unconfined Aquifer During January Through June 1963 . . . . . 6.39

6.27 Distribution of Average Tritium Concentrations in the Unconfined Aquifer During July Through December 1963 . . . . . 6.40

6.28 Estimated Distribution of Trave1 Time for Tritium and Ruthenium-106 Between PUREX Discharges (in the 200-East Area) and the Columbia River .............. 6.41

6.29 Distribution of Average Tritium Concentrations in the Unconfined Aquifer During July through December 1965 . . . . 6.42

6.30 Distribution of Average Tritium Concentrations in the Unconfined Aquifer During July Through December 1966 . . . . . 6.43

6.31 Distribution of Average Tritium Concentrations in the Unconfined Aquifer During July Through December 1967 . . . . . 6.44

6.32 Distribution of Average Tritium Concentrations in the Unconfined Aquifer During January Through June 1973 . . . . . 6.45

6.33 Distribution of Average Tritium Concentrations in the Unconfined Aquifer During January through December $1977 \ldots$. . 6.47

6.34 Distribution of Average Tritium Concentrations in the Unconfined Aquifer During 1979 . . . . . . . . . 6.48

6.35 Distribution of Average Tritium Concentrations in the Unconfined Aquifer During $1985 \ldots . . . . . .6 .50$ 
6.36 Distribution of Average Tritium Concentrations in the Unconfined Aquifer During $1986 \ldots . . . . . . .6 .51$

6.37 Distribution of Average Tritium Concentrations in the Unconfined Aquifer During $1988 \ldots \ldots . . . . . .6 .52$

6.38 Average Travel Times for Tritium and Nitrate from the 200-East Area to the Columbia River, Estimated by the USGS . . 6.54

6.39 Distribution of Monitoring Wells Used to Sample for Iodine-129 During 1979 . . . . . . . . . . . 6.57

6.40 Location of Offsite Wells Sampled for Iodine-129 . . . . . 6.59

6.41 Iodine-129 Monitoring Results for Offsite Wells . . . . . . 6.60

6.42 Comparison of Iodine-129 Concentrations in We11s in Confined Aquifers at the Hanford Site . . . . . . . 6.62

6.43 Distribution of Uranium in Ground Water Beneath the 300 Area During 1987 ............... . 6.68

6.44 Average Annual Tritium Concentrations Measured in Columbia River Water at Upstream and Downstream Locations, from 1974 Through 1989 ........................ 6.76

6.45 Average Annual Iodine-129 Concentrations Measured in Columbia River Water at Upstream and Downstream Locations, from 1977

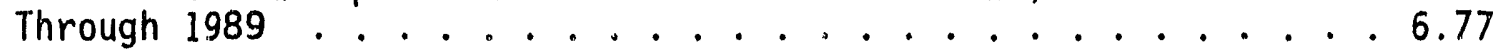

6.46 Offsite We11-Sampling Locations During 1988 and 1989 . . . . 6.81

7.1 Locations of Water Systems Used to Provide Sanitary Water at the Hanford Site During $1987 \ldots . . . . . . . .7 .2$

7.2 Concentration History of Tritium in Drinking Water at FFTF . . 7.7

7.3 Location of Ground-Water Monitoring Wells Near the North Richland Well Field.............. . 7.10 


\section{TABLES}

S.1 Summary of Dose Estimates for the Four Ground-Water Pathways . . xii

4.1 Total Radionuclide Inventories Present as Solid Wastes Placed in the Ground at the Hanford Site as of 1989 . . . . . . . 4.15

4.2 Total Radionuclide Inventorias Present in the Ground from Liquid-Waste Disposal at he Hanford Site as of 1989 . . . . . . 4.16

5.1 Effects of Well Remediation from 1974 to 1977 . . . . . . . . . . 5.4

5.2 Analytical Detection Limits for Radionuclides as of September 22, 1959 . . . . . . . . . . . . . . . . . 5.9

5.3 Routine Analytical Detection Limits for Radionuclides in 1962 . . 5.10

5.4 Analytical Detection Limits for Radionuclides Monitored in Ground Water at the Hanford Site During 1976 . . . . . . . . . 5.11

5.5 Analytical Detection Limits for Ravionuclides Monitored in Ground Water at the Hanford Site During 1989 . . . . . . . . .

6.1 Major Radiological Contaminants in the Ground Water and Their Link to Site Operations

6.2 Chronology of "Firsts" for Ground-Water Monitoring at the Hanford Site .. . . . . . . . . . . . . . . . . .

6.3 Ratio of Ruthenium-106 to Cobalt-60 for Selected Wells Southeast of the 200 -East Area During 1974 . . . . . . . . . . .

6.4 Iodine-129 Concentrations in Selected Wells Monitoring the Unconfined Aquifer During 1976 . . . . . . . . . . . . .

7.1 Summary of Monitoring Results for the Water Supply at the FFTF .......................

7.2 Concentrations of Iodine 129 Reported in Drinking Water at the FFTF

7.3 Radionuclide Concentrations in Orinking Water at the WNP-2 Construction Site During 1976 .................

9.1 Summary of Radionuclide Screening for Watershed Pathway Calculation (Assuming No Sorption of Radionuclides) 
9.2 Summary of Parameter Variations for the Watershed Sensitivits

Analysis .................... . . 9.6

9.3 Summary of Predicted Concentrations of Ruthenium-106 for

the Watershed Sensitivity Calculation . . . . . . . . . . 9.6

9.4 Summary of Dose Calculations for the Watershed Sensitivity

Calculation ..................... . . . 9.7 


\subsection{INTRODUCTION}

One of the possible pathways for radionuclides from Hanfoid Site operations to have reached the public is through ground-water transport. The contribution to dose by contamination transported through the ground-water pathway was investigated and is summarized in this report.

Following the introduction (Siction 1), the technical approach of this study and the data quality objectives are described in Sections 2 and 3 , respectively. In Section 4, a general description of ground water at the Hanford Site and a summary of the impact of Hanford operations on Site ground water are provided. Monitoring technologies used at the Site are described in Section 5. In Section 6, the movement of contaminated Hanford Site ground water is discussed, with emphasis on offsite migration. In Section 7, possible radiation doses from drinking water from wells on and adjacent to the Hanford Sits are described. In Section 8, potential doses from radionuclides in riparian wells downstream from the Hanford Site are summarized. In Section 9, a summary of possibie doses from atmospheric deposition on a small watershed and transport through a shallow ground-water system is provided. Finally, conclusions and a recommendation are provided in Section 10.

The report has four appendixes. Appendix A is TSP Directive 88-4, which directs Battelle to investigate the ground-water pathway. Appendix $B$ ontains a summary of sanitary-water systems (for drinking and other uses) at the Hanford Site. Appendix $C$ is a list of communities whose water might have come from riparian wells downstream of Hanford. Appendix $D$ is a glossary of some of the technical terms used in this report. Appendix $E$ is a compilation of the Techrical Steering Panel's comments and Battelle's responses.

\subsection{BACKGROUND}

The Hanford Environmental Dose Reconstruction (HEDR) Project was

prompted by concern about possible health effects to the public from more than 45 years of nuclear operations at the Hanford Site (Figure 1.1). Battelle, Pacific Northwest Laboratories (Battelle) staff perform the research on the 


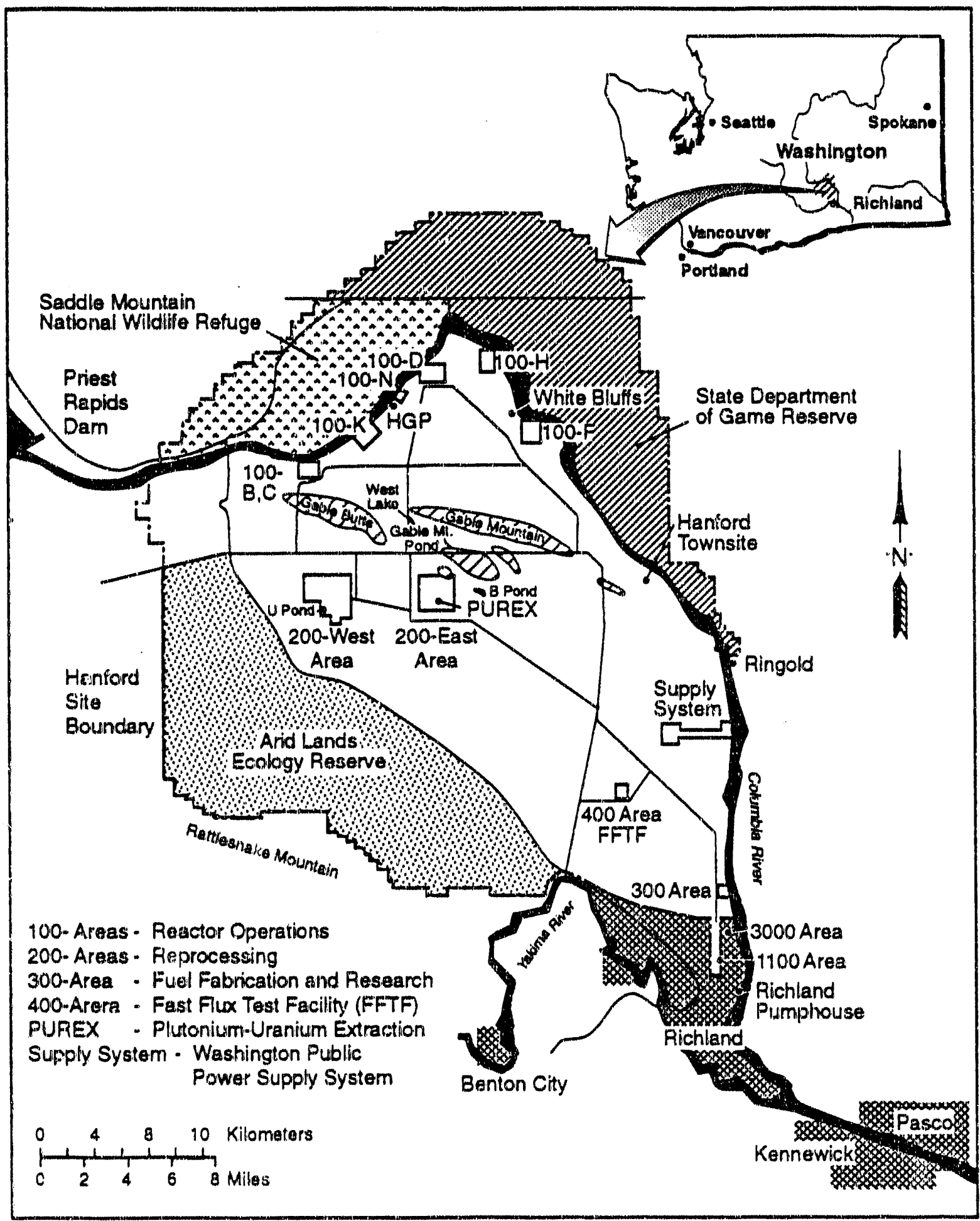

S9112077.36

EIGURE 1.1. Location of the Hanford Site in Washington State (after Jaquish and Bryce 1990) 
HEDR Project under the direction of an independent Technical Steering Panel (TSP). The TSP makes decisions on technical direction and reviews and approves all HEDR repurts. One mechanism by which the TSP communicates with and provides direction to Battelle staff is by directives. The TSP issued Directive 88-4, Ground-Water Contamination Data, (see Appendix A) in 1988 to provide direction for investigation of the general ground-water pathway. A preliminary response to the directive was generated by Freshley (1989). This report expands the original response to cover the other two ground-water pathways and provides additional detail.

Since 1944, large quantities of liquids (primarily water) containing radionuclides have been discharged to the ground surface or subsurface at the Hanford Site. (a) A total volume of 444 billion gallons of liquids has been discharged to the ground from $19 / 4$ through 1989. The total quantity (or inventory; of radionuclides discharged to the ground has been reduced iy radioactive decay; as of 1989, the quantity of radionuclides in the unsaturated zone and the ground water was approximately 678,000 curies ( $\mathrm{C} i$ ). Because of these discharges and their impact on ground water at the Hanford site, the ground-water pathway was of interest to the HEDR Project.

\subsection{PURPOSE}

The purpose of this investigation was to determine the extent to which radioactivity in ground water within and near the Hanford Site contributed to radiation doses received by representative offsite individuals and populations from 1944 to the present.

\subsection{SCOPE}

The scope of this report is to describe the potential contribution to dose of radionuclides in the ground water on and adjacent to the Hanford Site from 1944 to the present. A summary is provided for the movement of

(a) From an Aprit 1991 presentation by Westinghouse Hanford Company, "Historical Perspective of Radioactively Contaminated Liquid and Solid Wastes Discharged or Buried in the Ground at Hanford. "Available in the Public Reading Room, Federal Building, Richland, Washington. 
radionuclides that contaminated ground water in all of the Hanford Site operational areas, including the 300 Area where fuel was fabricated, the 100 Areas where the reactors are, and the 200 Areas where spent fue 1 from the reactors was reprocessed. All radionuclides monitored in the ground water were considered, but the greatest amount of information exists for gross beta, tritium, and iodine-129. Populations and individuals that may have been affected by ground water contaminated with radionuclides are 1) visitors to the Hanford Site and 2) those living adjacent to the Hanford Site and downstream along the Columbia River, which was impacted by Hanford Site ground water and direct discharges to the river from the reactors. 


\subsection{IECHNICAL APPROACH}

The potential radiation dose from the ground-water pathway was addressed by reviewing and summarizing literature published on Hanford Site ground water and by performing calculations to evaluate impacts where monitoring results were not available.

Weekly, monthly, and annual monitoring reports, as well as ground-water reports published by both Hanford Site and offsite sources were reviewed and summarized. A general summary of ground water at the Hanford Site is provided in Section 4. Changes in the monitoring technologies over time are described in Section 5. The results of the review of documents on offsite migration are summarized in section 6 . In this report, radionuclide concentrations are reported in the units used in the original references. Where necessary, they have been converted to consistent units (picocuries per liter $[p C i / L]$ ), which are shown in parentheses. In addition, other parameters (length) are reported in the original units used in the references where the information was extended.

The average radionuclide (tritium) concentrations in the Columbia River were estimated with calculations of contaminated ground-water discharge to the river. Tritium concentrations measured in ground-water wells near the river were scaled (multiplied) by the ratio of the ground-water discharge to the average annual flow rate of the Columbia River to estimate the concentration in the river. The results of these calculations, discussion of assumptions, and comparison with previous calculations and river monitoring results are summarized in Section 6 .

The drinking-water well pathway was addressed by reviewing drinkingwater monitoring reports published by the Hanford Environmental Health Foundation (HEHF) and other Hanford Site contractors. Reports for offsite water supply wells by the Washington State Department of Ecology and the Washington State Jepartment of Social and Health Services were also reviewed and summarized (Section 7). The riparian-well pathway was addressed by identifying factors that affect radionuclide concentrations in riparian wells 
and extrapolating impacts from previous estimates (PNL 1991b) of dose for the Columbia River pathway (Section 8).

The vatershed pathway was addressed by hypothetical calculations of shallow ground-water transport in a small watershed. Transport of radionuclides released to the atmosphere was estimated based on atmospheric modeling conducted during Phase I of the HEDR Project (PNL 1991c). Assumptions of recharge to the shallow ground-water system and a 1-year travel time in the ground water were used to estimate concentrations at a well or spring (Section 9).

Radiation doses for the ground-water pathways were either extracted from published literature or calculated by hand. Doses for the offsite migration and drinking-water pathways were obtained from published literature. Various monitoring reports have been published by contractors at the Hanford Site and offsite to address the offsite migration and drinking-water pathways. Radiation doses associated with the riparian-well pathway were estimated based on a limited amount of available information. The doses for drinking columbia River water are an upper limit for the riparian-well pathway because the source of radionuclides for the dose calculations is the river. The Phase I results for the Columbia River pathway (PNL 1991b) were used to estimate maximum potential doses for the riparian-well pathway. Radiation doses for the watershed pathway were calculated based on hypothetical radionuclide concentrations predicted to reach a well or spring in the small watershed and on the assumption that an individual drank the water.

The results of dose calculations or previously published estimates for the ground-water pathway were compared with the TSP dose decision level of $100 \mathrm{mrem} / \mathrm{y}$ effective dose equivalent for an adult. (a) This comparison was made to place dose estimates for the ground-water pathway into perspective and determine their importance relative to the other major pathways, atmospheric and surface-water transport.

(a) Shleien, B. 1992. "Scoping Document for Determination of Temporal and Geographic Domains for the HEDR Project." Prepared for the Technical Steering Panel, approved by the Panel in April 1992. Washington State Department of Ecology, 1-800-545-5581. 


\subsection{ACHIEVEMENT OF DATA QUALITY OBJECTIVES}

Data quality objectives were established in the FY 1992 task plans for ground-water transport (PNL 1991d) to address accuracy, precision, completeness, representativeness, and comparability. Each of these objectives was to be addressed in completing the investigation for the ground-water transport task.

In most cases, no new data were generated for the ground-water pathway. Because most of the data were from existing monitoring reports, accuracy was ensured by checking the data in this report against the original sources for transcription errors. For the simple calculations of ground-water discharge, the estimates of tritium discharge to the Columbia River were compared with calculations made by other researchers (Prater et al. 1984) and with the results of monitoring tritium concentrations in the river (Jaquish and Bryce 1990). For the calculations performed to estimate the impacts of atmospheric deposition on a watershed and shallow ground-water flow to a well or spring, no monitoring data were available for comparison of results.

Precision was include: as part of the data quality objectives to quantify uncertainties in reported and calculated radionuclide concentrations and doses. Most of the ground-water monitoring results presented in this report are summarized in maps showing the extent and/or distributions of contamination. Because these maps were taken from published weekly, monthly, annual, and topical Hanford Site reports, they are interpretations of the data by the researchers who reported it. Where the information is available, analytical detection limits and monitoring technologies such as well construction and sampling and analysis methods are included in the discussion of the map interpretations. Uncertainty of the existing monitoring data was difficult to assess because not all of the monitoring reports include information on the analyses that were used to generate results or even on the detection limits during the early years. Reporting of analyses used and detection limits improved with time, as did reporting the results of multiple samples as 
ranges. One part of the ground-water transport task was to demonstrate how interpretations of the monitoring data changed with time and with improvements in the monitoring technology.

Uncertainties were included in the calculations performed for the ground-water pathway. Ranges of radionuclide concentrations and doses are presented where possible. This approach was used to ensure that the calculations account for variability (uncertainty) in the input parameters.

Completeness was included as a data quality objective to ensure that discovery of any additional ground-water concentration data would not change the conclusions of the investigation (PNL. 1991d). Completeness of the review of ground-water data for the Hanford Site was ensured by reviewing all weekly, monthly, quarterly, and annual monitoring reports published since operations began in 1944 and summarizing the results of the review in this report. An annotated bibliography was developed for the documents that were reviewed and is available as a project recorc. (a) In addition to the published monitoring reports, topical reports describing various studies of ground water at the Hanford Site and reports from the Basalt Waste Isolation Project (BWIP) were reviewed. Outside publications by state agencies (Washington State Department of Ecology and Washington State Department of Social and Health Services), independent consulting firms (SEARCH Technical Services, Inc.), and the U.S. Geological Survey (USGS) were also reviewed.

All of the ground-water monitoring results for the Hanford Site are not included in this report; there are far too many data to include them all. These data are included in the Hanford Site Ground-Water Data Base implemented on a computer system at the site. Interpretations of the monitoring data and how the interpretations changed with time are presented. Where insufficient data were available for previous researchers at the Hanford Site to provide map interpretations ( $p l u m e s)$, the data are included in this report as tables. Data listings are provided only where changes from previous reporting periods were noted by the researchers.

(a) Available at the Public Reading Room, Federal Building, Richland, Washington. 
The data quality objective on representativeness was included to ensure that results of the investigation were representative of the conditions existing at or near the Hanford Site during the past 45 years. The data quality objective on comparability was included to ensure that results presented in this report were comparable to the existing reports. Because the results presented were extracted from the published monitoring and topical reports, they are representative of conditions exi:sing at the time of the reports. However, it is important to recognize that the results are based on interpretations of the available monitoring data. Individua?s with considerable ground-water monitoring experience peer reviewed this report to ensure that the results were representative of monitoring data on Hanford Site ground water. 


\subsection{HANFORD SITE GROUND WATER}

Ground water at the Hanford Site (see Figure 1.1) has been investigated since before Site operations began in 1944. Parker and Piper (1949) summarized early investigations of Hanford Site geology and hydrology by the USGS. The USGS followed the early investigations with other reports on the Hanford Site: 1) Newcomb and Strand (1953), which is a modification of Parker and Piper (1949); 2) Newcomb, Strand and Frank (1972); and 3) more recently, USGS (1987). In addition to the USGS investigations, geologic and hydrologic characteristics at the Site have been summarized in a number of reports by Hanford contractors (duPont de Nemours, General Electric Company, Atlantic Richfield Hanford Company, Rockwell Hanford Operations, Westinghouse Hanford Company, and Pacific Northwest Laboratory) and in DOE publications such as the Site Characterization Plan (DOE 1988) for the BWIP.

Both confined and unconfined aquifers are present beneath the Hanford Site (Jaquish and Bryce 1990). The unconfined, or water-table, aquifer is in lake-deposited and glacially deposited sediments overlying the basalts (Figure 4.1). This relatively shallow unconfined aquifer has been affected by waste-water disposal resulting from operations at the Site (Graham et al. 1981). The confined aquifers are found primarily between layers of the Columbia River basalts. Each of these aquifers is confined by less permeable geologic layers above and below. Ground water in these aquifers is under pressure greater than that of the atmosphere.

\subsection{MOVEMEN: OF GROUND WATER AT THE HANFORD SITE}

The general flow pattern within the unconfined aquifer at the Hanford Site is from recharge areas in the west to discharge areas (Columbia River) in the east, as illustrated by the water-table map for June 1989 (Figure 4.2). As the unconfined aquifer has been recharged from waste-water disposal in the 200 Areas of the Site, the ground-water level has risen, altering the local flow pattern for the aquifer. The water table in 1944, before Hanford Site 


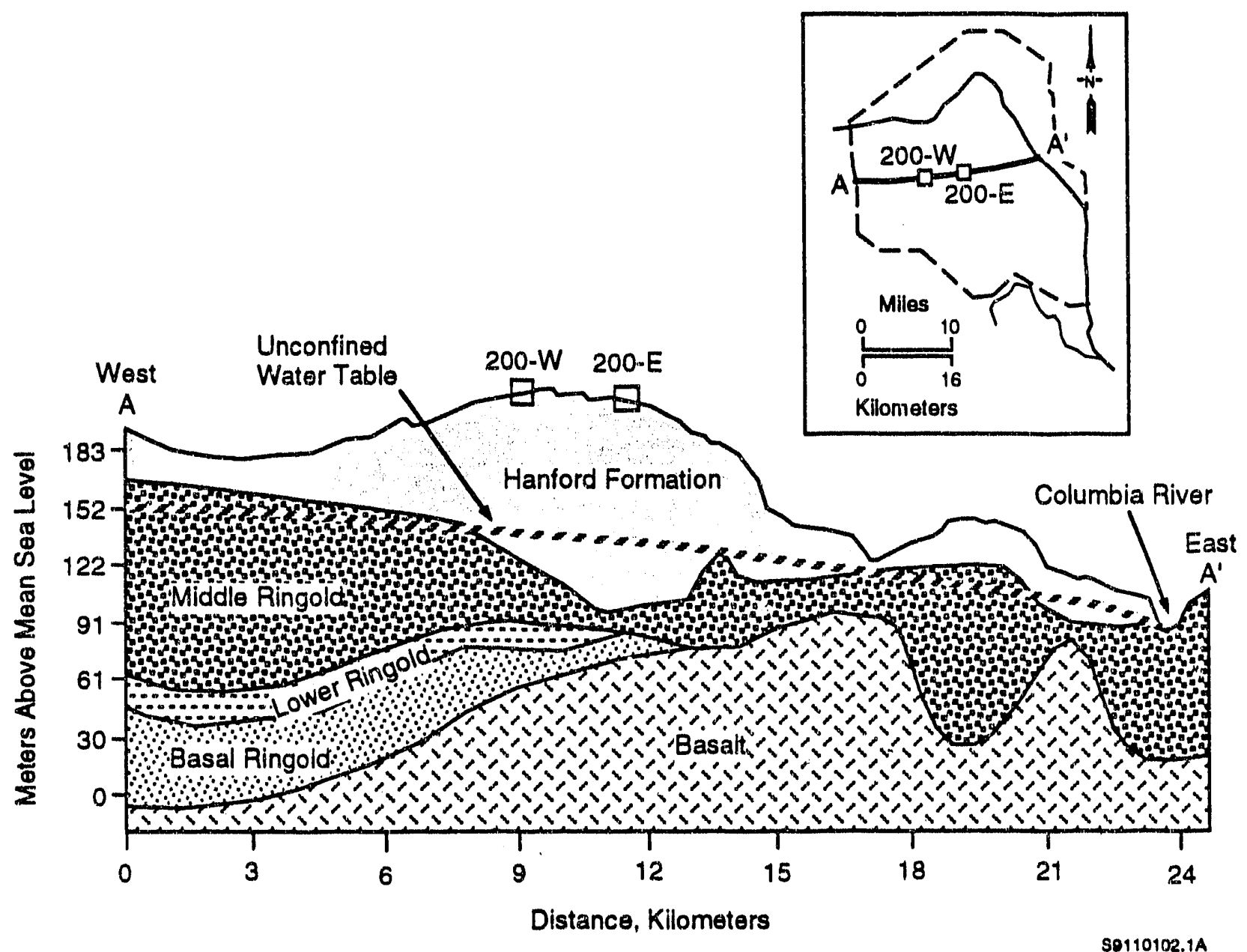

33.53 FIGURE 4.1. Schematic Geologic Cross Section for the Hanford Site (after Tallman et al. 1979)

operations began, is illustrated in Figure 4.3. Water levels in the unconfined aquifer have changed continuously during Site operations because of variations in the volume of waste water discharged to the ground (Zimmerman et a1. 1986; Newcomer 1990). As a result of these water-level variations and other influences, both the movement of ground water and contaminants in the ground water have changed with time.

Ground water in the confined aquifers within the Columbia River basalts originates primarily as precipitation that infiltrates in elevated recharge 


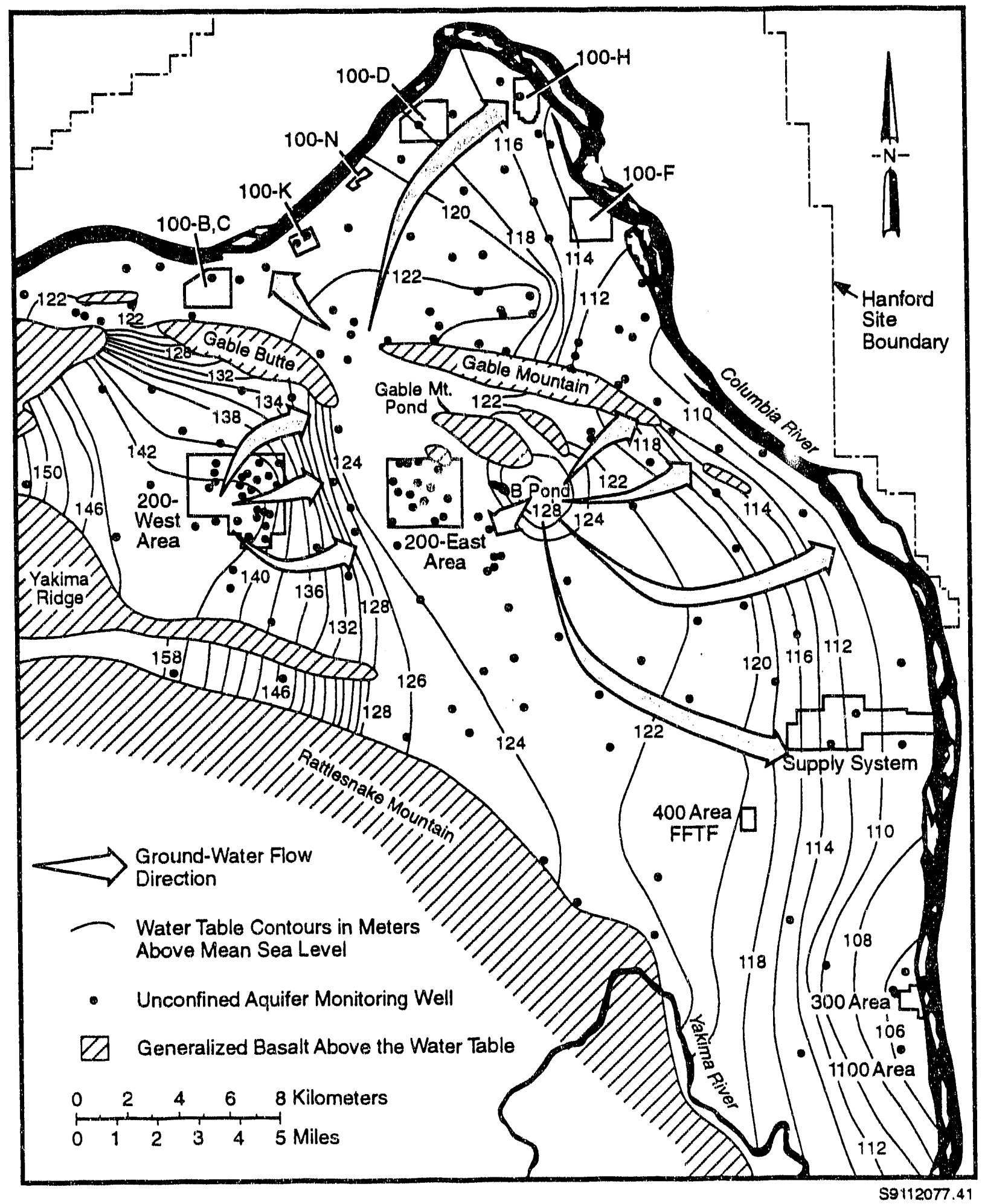

34.51 FIGURE 4.2. Water Table Elevations at the Hanford Site for June 1989 (after Jaquish and Bryce 1990) 


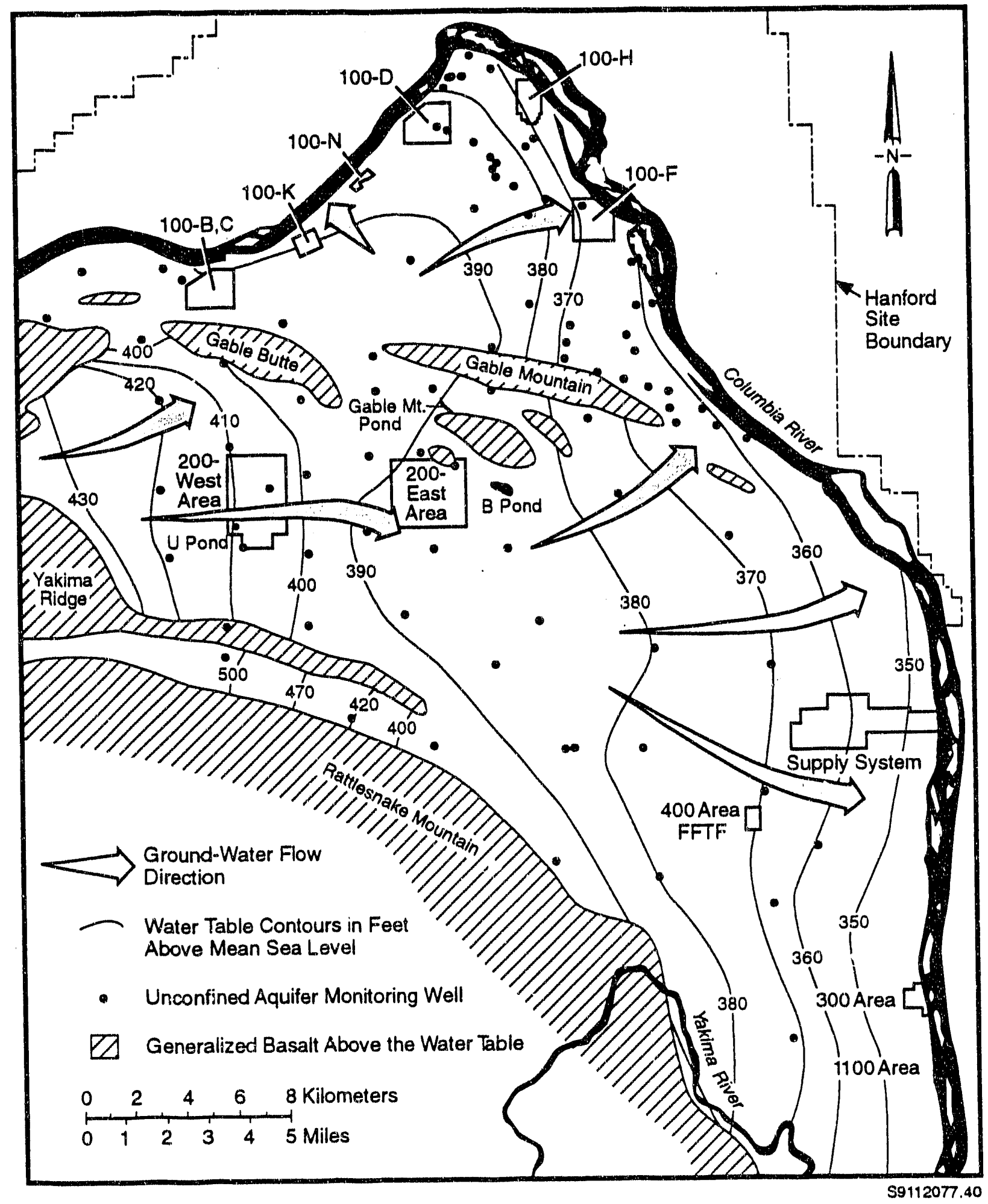

EIGURE 4.3. Water Table Elevations at the Hanford Site for 1944 (after Kipp and Mudd 1974) 
areas surrounding the Columbia Basin (DOE 1988). The Columbia Basin is defined by the areal extent of the Columbia River basalts, which were restricted during their eruptions by the Cascade Mountains to the west, the Blue Mountains to the east, and highlands to the north and south. The upper confined aquifers are artificially recharged by irrigation, mainly in the eastern and northeastern portions of the Pasco Basin (a subbasin of the Columbia Basin), where the basalt formations are at or near the land surface (Gephart et a1. 1979).

On the Hanford Site, ground water in the uppermost confined aquifer flows primarily from the west to the east toward the Columbia River (Figure 4.4). Hydraulic-head measurements made in wells on both sides of the Columbia River show that ground water in the confined aquifer flows toward the river (Bauer, Vaccaro and Lane 1984). Ground water in the uppermost confined aquifers eventually discharges to the Columbia River (DOE 1988). However, the river is not a line marking the exact point of discharge from the confined aquifers, as it is for the unconfined aquifer. Ground water in the confined aquifers likely discharges first to the unconfined aquifer and then to the river.

Vertical flow of ground water between confined aquifers in the Columbia Basin is impeded by the low hydraulic conductivity of the basalt confining units. The dense interior sections of the basalt flows have vertical hydraulic conductivities that are about five orders of magnitude lower than the moderately conductive tops of the flows and sedimentary interbeds (DOE 1988). Therefore, because they are closest to the surface, the uppermost confined aquifers, the Saddle Mountains Basalt flow top, and the Rattlesnake Ridge Interbed have the greatest potential for contamination by radionuclides that have entered the unconfined aquifer from Hanford Site operations.

A comparison of measured hydraulic heads (water levels) for the unconfined aquifer (Figure 4.2) and hydraulic heads in the upper confined aquifers (Figure 4.4) at the Hanford Site (DOE 1988) shows that in the western half of the Site, hydraulic heads are higher in the unconfined aquifer than in the confined aquifer; in the eastern half of the Site, they are higher in the confined than in the unconfined aquifer. Therefore, over the western half of 


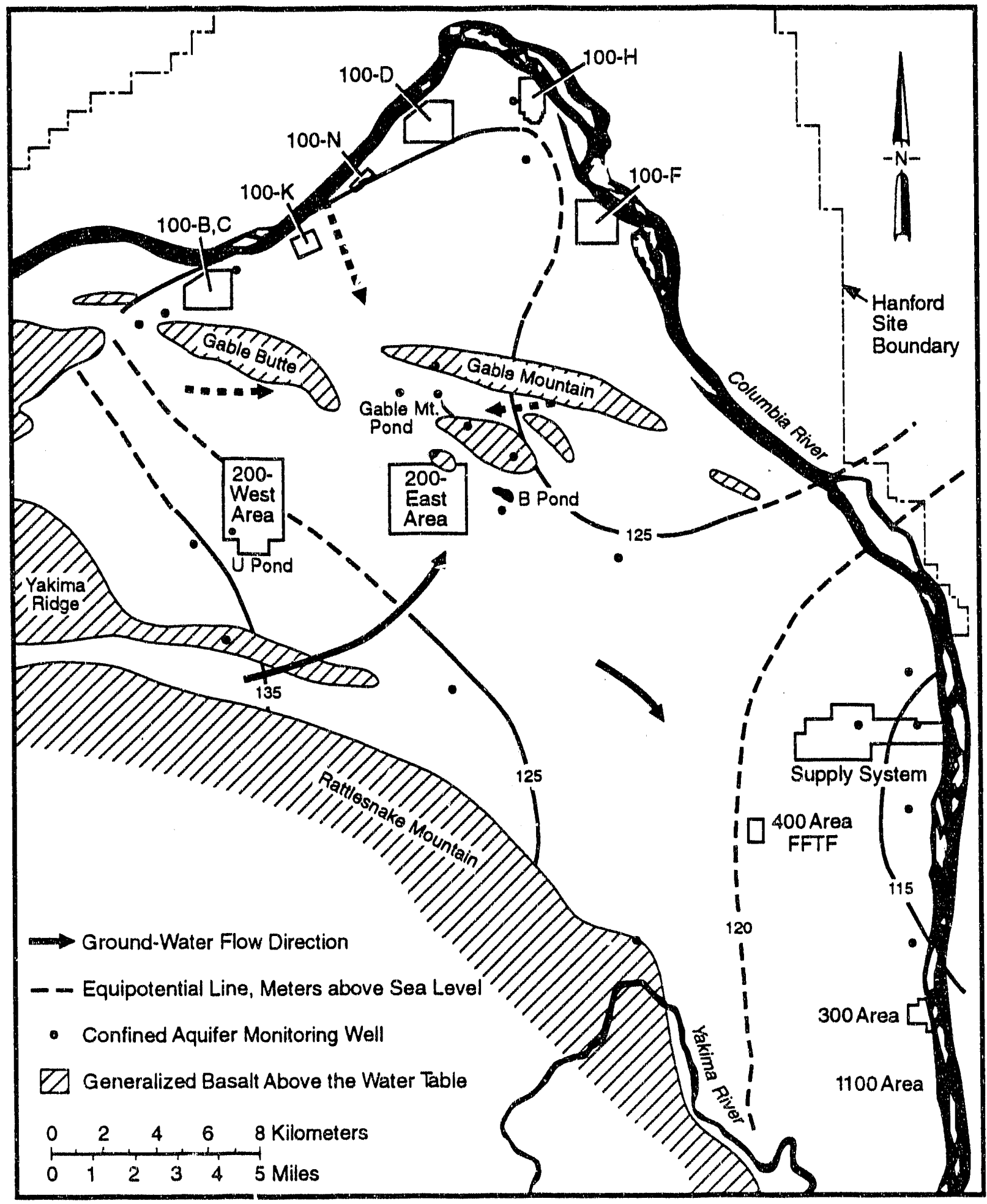

\$9112077.22

FIGURE 4.4. Hydraulic-Head Map of the Rattlesnake Ridge Confined Aquifer Within the Hanford Site (after Graham, Last and Fecht 1984) 
the site, ground water can move downward from the unconfined to the confined aquifer. Over the eastern half of the site, ground water can move upward from the confined to the unconfined aquifer.

The Gable Gap area southwest of Gable Mountain has been shown to be an area of increased vertical movement of water between the unconfined aquifer and the uppermost confined aquifers (Graham, Last and Fecht 1984; Early, Hall and Johnson 1988). According to Graham, Last and Fecht (1984), this increased vertical movement results from hydraulic gradients created by waste-water disposal in the 200 Areas, deformation from formation of Gable Mountain and Gable Butte, and localized erosion of the upper confining layers.

\subsection{SOURCES OF RADIONUCLIDES IN HANFORD SITE GROUND WATER}

The Hanford Site was established in 1943 as the location for facilities needed to produce plutonium for atomic weapons used in World War II; operations at the Site began in 1944. Radionuclides in ground water at the Hanford Site are from operations in the 100, 200, and 300 Areas of the Site. Fuel for the reactors was fabricated in the 300 Area; reactor operations to irradiate uranium fuel to create plutonium occurred in the 100 Areas; and chemical separation of plutonium from uranium and fission products present in the irradiated fuel was done in the 200 Areas. Research and development activities were also conducted in the 300 Area.

The waste products from operations were discharged to underground disposal facilities designed to receive the wastes. As previously described in Section 1.1 , about 444 billion gallons (1.7 billion cubic meters $\left[\mathrm{m}^{3}\right]$ ) of liquids were discharged to the ground, and approximately $678,000 \mathrm{Ci}$ of radionuclides were present in the unsaturated zone and ground water as of 1989. (a) The waste-disposal facilities at the Hanford Site are described in Parker (1954), Energy Research and Development Administration (ERDA) (1975), and Stenner et al. (1988) and are summarized in this section of the report.

(a) From an April 1991 presentation by Westinghouse Hanford Company, "Historical Perspective of Radioactively Contaminated Liquid and Solid Wastes Discharged or Buried in the Ground at Hanford." Available in the Public Reading Rooin, Federal Building, Richland, Washington.

\section{7}




\subsubsection{Contamination from Solid-Waste Disposal}

Contaminated solid wastes have been disposed to the ground at the Hanford Site since 1944 (Stenner et al. 1988). These wastes have been disposed underground in trenches, caissons, and tunnels and on retrievable storage pads. Most of these solid-waste facilities were backfilled trenches of different sizes and shapes. A cross section of a typical solid-waste trench is illustrated in Figure 4.5. Contaminated materials placed in the trenches consisted primarily of failed equipment placed in concrete, wooden, or metal boxes. Dry wastes consisted of contaminated rags, paper, filters, disposable supplies, soil, small pieces of equipment, as well as other small disposable items packaged in 4.5-cubic-foot $\left(\mathrm{ft}^{3}\right)$ cardboard boxes.

Solid-waste disposal facilities are present in all of the operating areas, but have not contaminated the ground water (Stenner et al. 1988). Contaminants are released slowly from the solid wastes; radionuclides associated with the solid wastes have not migrated far from the waste sites because of the dry climate at Hanford and the low recharge rate (Gee and Heller 1985).

\subsubsection{Contamination from Liquid-Waste Disposal}

As with solid wastes, radioactive liquid wastes have been generated at the Hanford Site since 1944 (Stenner et al. 198E). These wastes have been discharged to ponds and swamps, ditches, trenches, cribs, caverns, french

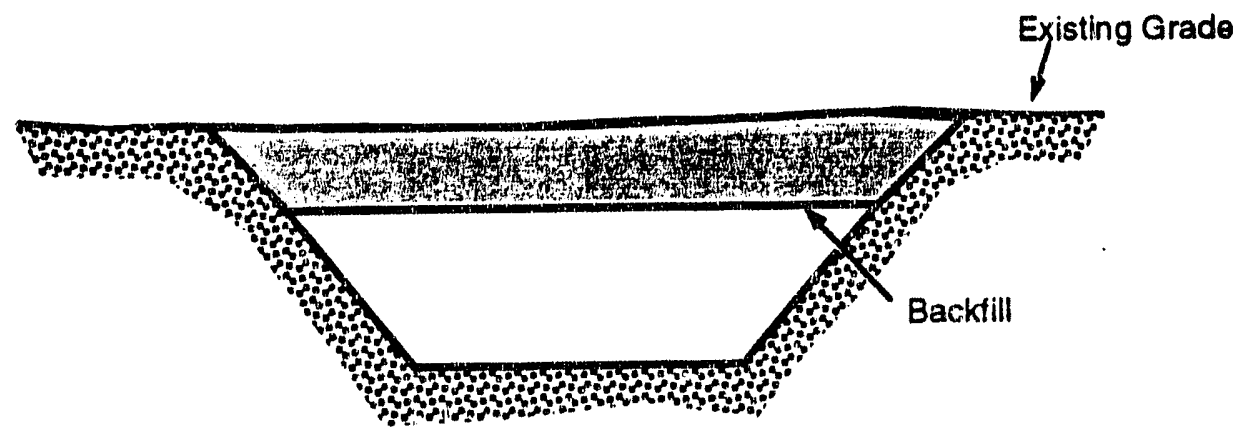

S9112086.5

FIGURE 4.5. Schematic Cross Section of a Typical Solid-Waste Trench (after Stenner et al. 1988) 
drains, sumps, and reverse wells. The liquid wastes discharged to the ground include uncontaminated water, water contaminated with low-level radioactive wastes, and some water contaminated with high-level radioactive wastes.

The locations of many of the early radioactive liquid-waste disposal facilities were documented in Clukey (1954a and 1956). The name, type of structure, location in Hanford coordinates, surface and bottom elevations, waste source, and drawing numbers of eariy facilities were all identified by clukey (1954a and 1956). The locations of facilities constructed after 1956 were summarized by Stenner et a1. (1988).

Discharge of liquids containing radionuclides to the waste-disposal facilities was the primary inechanism for contamination of the ground water at the Hanford Site. The different types of disposal facilities and the waste each received are described below.

Ponds and swamps at the site are bodies of water in natural or manmade surface depressions. The ponds were used for disposal of large volumes of nonradioactive liquid effluent from cooling and process operations and other streams such as laundry wastes. Some radioactivity was introduced to these effluent streams from failure of process vessels and piping. As the effluent seeped into the ground, many of the radionuclides such as strontium-90 were adsorbed by the soil. To prevent the contaminated soil from spreading by atmospheric transport, clean water was routinely discharged to the ponds to maintain the surface area of the pond and prevent drying.

A cross section of the unsaturated zone beneath a typical pond is illustrated in Figure 4.6. Major ponds used at the Hanford Site were $U$ Pond in the 200-West Area and Gable Mountain Pond and B Pond in the 200-East Area. These ponds received most of the process cooling water that was discharged to the ground in the 200 Areas. U Pond was decommissioned (shut down and covered with backfill) in 1984, and Gable Mountain Pond was decommissioned in 1987 (Freshley and Graham 1988).

Ditches are long, narrow, unlined excavations used for conveying to the ponds large volumes of process cooling water containing low levels of radioactivity. The ditches, therefore, had the same levels of contamination as the 


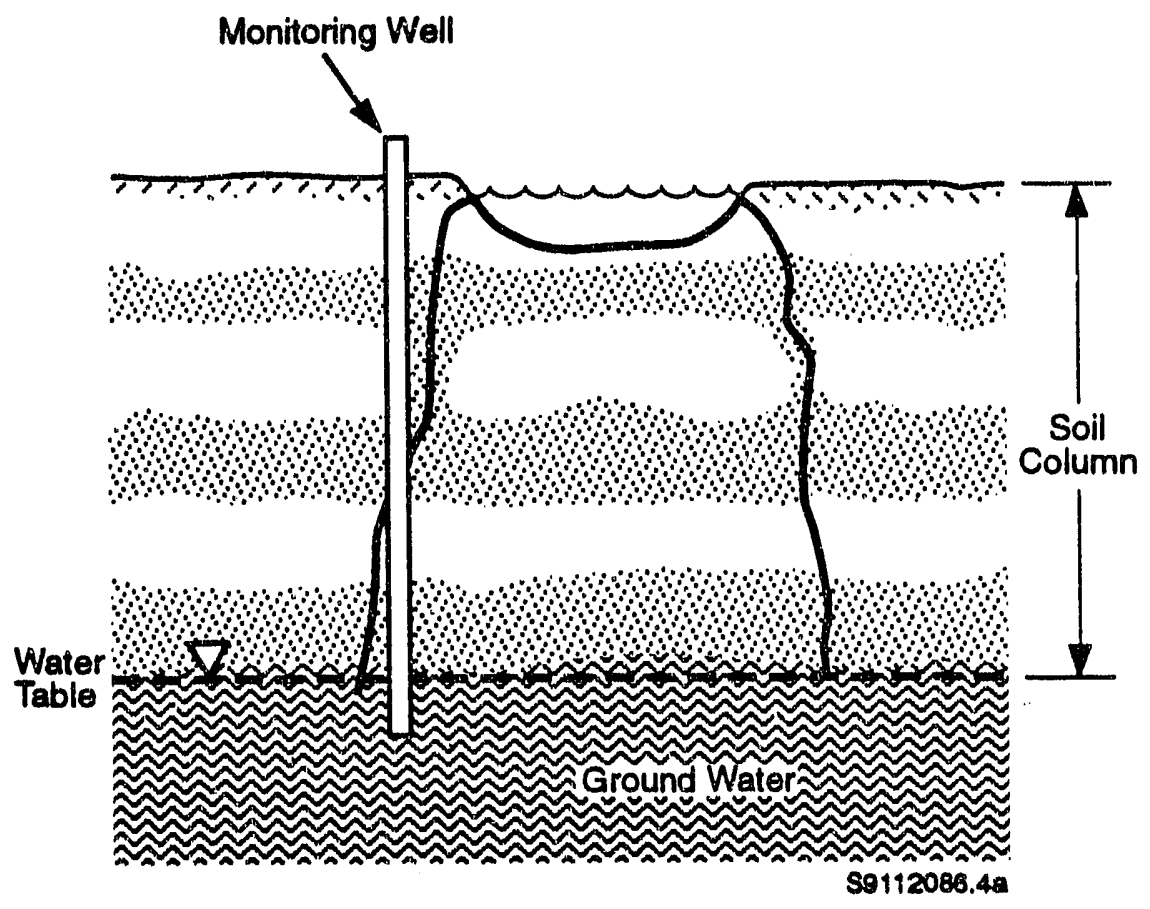

EJGURE 4.6. Schematic Cross Section of a Typical Disposal Pond (after Stenner et a1. 1988)

ponds. Ditches were also kept full to prevent contaminated soil from drying out and spreading by atmospheric transport.

Liquid-waste trenches are long, narrow, unlined excavations used for disposal of process cooling water containing low levels of radioactivity. Trenches in the 100 Areas were used over long periods of time for disposal of batches of reactor coolant water that contained radionuclides from failed fuel. The 200-Area trenches were generally used over short periods of time for disposal of limited quantities of radioactive effluent. Some of these liquid-waste trenches were covered; others were not.

The principle behind use of the liquid-waste trenches was for the radionuclides to remain close to the discharge point and the low-level radioactive waste to move vertically down toward the ground water (Parker 1954). Without continuous discharge of liquid to the trenches, radionuclides such as strontium-90 and cesium-137 were not expected to move downward very far toward the ground water. 
Cribs are soil-covered, liquid-waste disposal facilities usually filled with rocks and timbers. Different crib designs were used. The early designs consisted of timbered boxes that were open only at the bottom (see Figure 4.7). The liquid waste was discharged into the ground inside the box, which was also equipped with a vent line. Some cribs had either a second cavity or tile fields for spreading the discharge over a larger area.

Cribs constructed in later years were built by partially filling an excavation with sorted rock or gravel with a distribution pipe placed in the rock or gravel to provide uniform flow of liquid over the crib bottom. The gravel was topped by an impermeable membrane or layer of asphalt and the entire crib covered with soil to provide radiation protection and prevent dispersal of potentially contaminated soil.

Some cribs, known as caverns, consisted of covered gravel pits of different sizes designed to receive a variety of low-level wastes, primarily

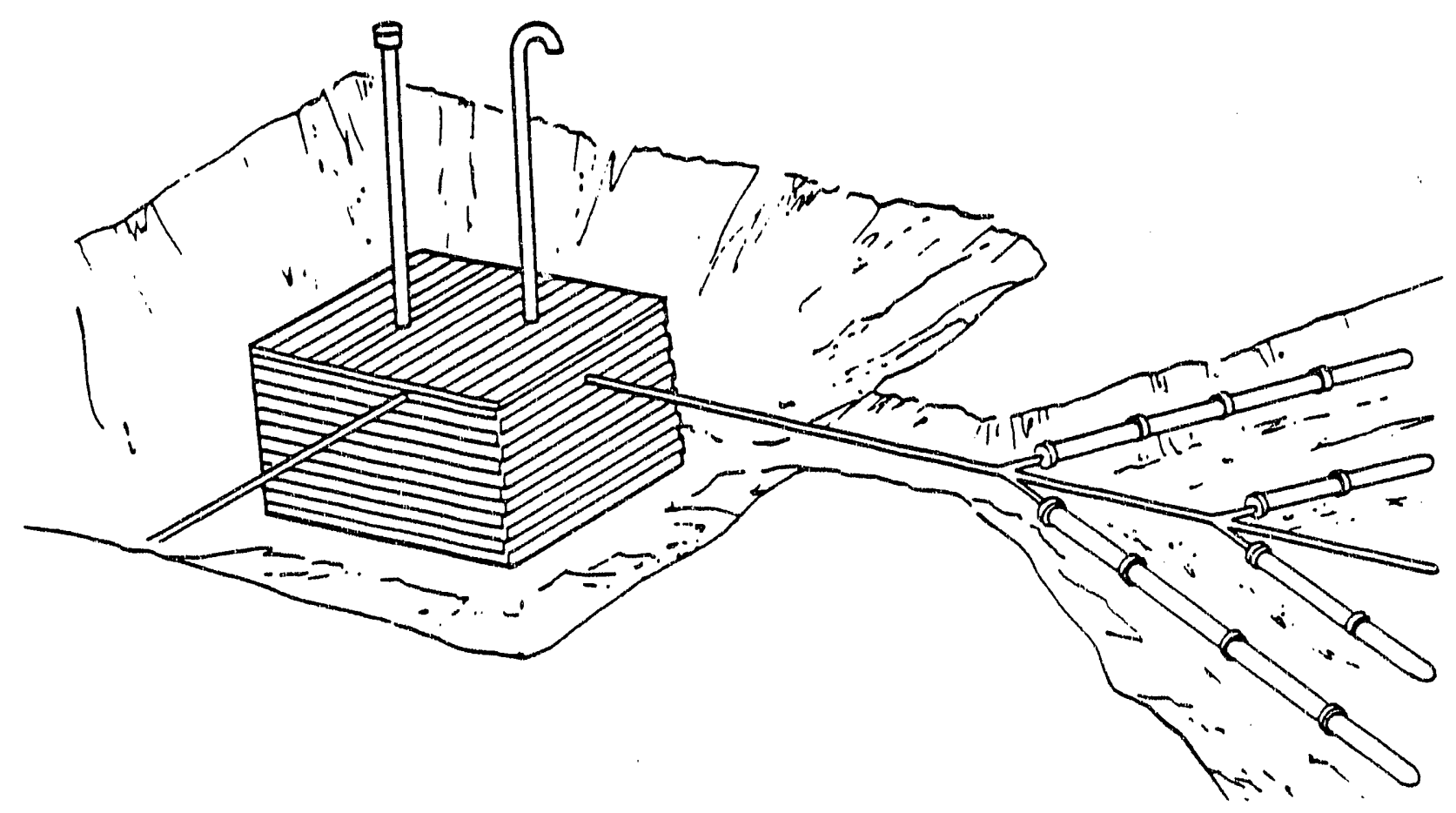

FIGURE 4.7. Schematic Diagram of a Typical "Timbered-Box" Crib (Stenner et al. 1988) 
process condensates and cooling water. During the early years of operations (the exact length of time was not specified), open trenches served the same function as cribs and were covered with wood, canvas, or plastic sheets to prevent airborne spread of contamination (Parker 1954).

Sumps are the same as liquid-waste disposal trenches, but are essentially square or round, rather than rectangular. Sumps were intended to receive only intermittent, low-volume waste discharges.

French drains are covered or buried rock-filled structures with an open bottom to allow liquid to drain into a gravel-filled excavation. French drains are similar to cribs, but are much smaller. They were used primarily for disposal of intermittent, low-volume waste streams.

Reverse wells are drilled holes or wells that were buried or covered. The lower end of the casing is perforated or open to allow liquid to drain into the soil or unsaturated zone. These wells were drilled to within several tens of feet of the water table. Early in Hanford Site operations, reverse wells were used to a limited extent for low-level wastes, but proved unsatisfactory because they plugged easily and introduced the wastes close to the ground water. According to Parker (1954), use of a reverse well early in Hanford Site operations resulted in a small amount of radioactive contamination in the ground water.

Other types of liquid storage facilities were used at the Hanford Site to store radioactive liquid wastes. Tanks and vaults were constructed to contain radioactive liquid wastes to prevent entry into the soil and unsaturated zone. Documented leaks in a number of the waste storage tanks have introduced contaminants into the unsaturated zone (DOE 1987). Smoot and Sagar (1990) summarized monitoring data and the results of computer simulations for the 241-T-106 single-shell tank leak. Results of the simulations demonstrated that under certain recharge and soil conditions, ruthenium-106 in the soil column (vadose zone) will reach the water table. 


\subsection{CLASSIFICATIONS OF RADIOACTIVE WASTE}

Liquid radioactive wastes at the Hanford Site were classified as highlevel, internediate-level, or low-7evel wastes (Brown and Raymond 1962b). This classification was used to determine whether the wastes were to be stored in tanks or discharged to the ground.

High-level wastes were those that contained most of the fission products from reprocessing operations in concentrations greater than 100 microcuries per milliliter $(\mu \mathrm{Ci} / \mathrm{ml})\left(10^{11} \mathrm{pCi} / \mathrm{L}\right)$. These wastes are stored in steel tanks buried beneath the ground at the Hanford site. The policy for operating the waste tanks was that no high-level wastes would be intentionally discharged to the ground (Brown and Raymond 1962b). However, leaks from the waste tanks have occurred (DOE 1987).

39,40,41 Intermediate-level wastes were those that had been separated from the high-level wastes and generally had radionuclide concentrations in the range of $10^{-5}$ to $100 \mu \mathrm{Ci} / \mathrm{ml}\left(10,000\right.$ to $\left.10^{11} \mathrm{pCi} / \mathrm{L}\right)$. Most intermediate-level wastes at the Hanford Site are stored underground in the high-level waste tanks. Some of the intermediate-level wastes, however, were discharged to trenches when evaluation of the particular waste showed that the soil column would effectively retain radionuclides contained in the waste.

$42,43,44$ Low-level wastes consisted of process cooling water and steam condensate that occasionally became contaminated from leaks in portions of the separations processes for recovering plutonium from spent fuel. The level of radioactive contamination in low-level wastes was not intended to exceed $10^{-5} \mu \mathrm{Ci} / \mathrm{ml}(10,000 \mathrm{pCi} / \mathrm{L})$. However, periodic difficulties with processing operations allowed small quantities of intermediate- and high-level wastes to enter these waste streams (Paas and Heid 1955). The large-volume, low-level radioactive waste streams were discharged to open swamps or ponds. Relatively low levels of radionuclides were discharged to the ground in swamps and ponds; these discharges had the greatest impact on the direction of flow in the unconfined aquifer because of the large volumes (see Figures 4.2 and 4.3). The smaller volume low- and intermediate-level radioactive waste streams discharged to cribs and trenches contributed the most to ground-water contamination at the Hanford Site. 


\subsection{INVENTORIES OF SOLID-WASTE DISPOSAL AND LIOUID-WASTE DISCHARGES}

Inventories of solid-waste disposal and liquid-waste discharges to the ground are summarized in Hanford Site documents provided by the various Hanford Site operating contractors. The amount of detail reported about the numbers of specific radionuclides in the waste streams and when discharges occurred increased with time. Seymour (1946) provided an early summary in total curies of radionuclides released to the environment through 1946 . Ruppert and Heid (1954) summarized the inventories of radionuclides in liquid process wastes discharged to the ground in the 200 Areas for the period July 1952 through June 1954. The document also provides a summary of discharges to the ground in the 200 Areas from the beginning of Hanford Site operations in 1944 to July 1954. The data are summarized for waste stream volume and concentrations of uranium, plutonium, beta emitters, cesium-137, and strontium90, with special analyses for antimony-125 and ruthenium-106. Paas and Heid (1955) provided a monthly summary of the amounts of radionuclides discharged to the ground at separations facilities in the 200-East and 200-West Areas from July 1954 through June 1955.

Clukey (1954b) summarized the inventories of radioactive liquid wastes discharged to the ground in the 300 Area during 1954. All of these wastes were associated with fuel fabrication activities; the dominant radionuclide present was uranium. Two of the waste streams were discharged to the ground; the third was accumulated in storage tanks inside a 300-Area building and trucked to a crib in the 200-East Area. Process wastes consisting primarily of unirradiated uranium were discharged in two diked surface ponds between the 300 -Area fence and the Columbia River.

The inventories of radionuclides stored in the greatest amounts as solid wastes in the ground at the Hanford Site are listed in Table 4.1. The inventories of radionuclides are decayed to 1989 (1isted as the inventories present during 1989, taking into account inventory reductions because of radioactive decay). Radionuclides other than those listed are present in solid wastes, but in much smaller quantities. The total volume of solid waste in the ground at the Hanford Site is approximately $625,000 \mathrm{~m}^{3}$. Additional solid-waste inventories are stored in strontium-90 and cesium-137 capsules $(173,500,000 \mathrm{Ci})$ in the 200 Areas; irradiated fuel storage $(62,870,000 \mathrm{Ci})$ in 
IABLE 4.1. Total Radionuclide Inventories Present as Solid Wastes Placed in the Ground at the Hanford Site as of $1989^{(a)}$

\begin{tabular}{lrr} 
Radionuclide & Inventory (Ci) & Disposal Location \\
\cline { 2 - 3 } Tritium & 266,800 & 100,200 Areas \\
Strontium-90 & $2,030,600$ & $100,200,300$ Ar \\
Cesium-137 & $2,541,200$ & $100,200,300$ Area \\
Carbon-14 & 6,300 & 100,200 Areas \\
Uranium & 560 & 200,300 Areas \\
Americium-241 & 1,100 & 200,300 Areas \\
Plutonium & 27,500 & 200,300 Areas \\
Total (curies) & $4,875,100$ & $100,200,300$ Area \\
& & \\
\hline & (a) From an April 1991 presentation by Westinghouse Hanford \\
Company, "Historical Perspective of Radioactively Con- \\
taminated Liquid and Solid Wastes Discharged or Buried \\
in the Ground at Hanford." Available in the Public \\
Reading Room, Federal Building, Richland, Washington.
\end{tabular}

the 100, 200, and 400 (Fast Flux Test Facility [FFTF]) Areas; and solids in above-ground storage facilities $(651,000 \mathrm{Ci})$. More than $99 \%$ of the solidwaste inventory is stored in the 200 Areas.

The inventories of radionuclides discharged to the ground in liquid effluent are 1 isted in Table 4.2. The inventories of radionuclides are also decayed to 1989 (11isted as the inventories present during 1989, taking into account inventory reductions because of radioactive decay). Some of the radionuclides described in Section 6 (such as ruthenium-106 and coba7t-60) were discharged to the ground but were decayed as of 1989 because of their relatively short half-lives. Other radionuclides were discharged to the ground, but in much smaller quantities. The total volume of liquids discharged to the ground at the Hanford Site is approximately $1,680,000,000 \mathrm{~m}^{3}$ $\left(1.7\right.$ billion $\left.\mathrm{m}^{3}\right)$. Additional liquid wastes $\left(245,000 \mathrm{~m}^{3}\right.$ and $\left.208,700,000 \mathrm{Ci}\right)$ are stored in the high-level waste tanks located in the 200 Areas. As with the solid wastes stored in the ground, more than $99 \%$ of the liquid effluent radionuclide inventory was disposed to the ground in the 200 Areas. 
IABLE 4.2. Total Radionucl ide Inventories Present in the Ground from Liquid-Waste Disposal at the Hanford Site as of $1989^{(a)}$

(a) From an Apri1 1991 presentation by Westinghouse Hanford Company, "Historical Perspective of Radioactively Contaminated Liquid and Solid Wastes Discharged or Buried in the Ground at Hanford." Available in the Public Reading Room, Federal Building, Richland, Washington.

\subsection{IESTS FOR GROUND DISPOSAL OF WASTES}

Tests were conducted before waste discharge facilities were used at the Hanford Site. Parker (1954) reported on laboratory studies to determine the capacity of Hanford Site soils to retain or sorb radionuclides contained in the liquid-waste streams discharged to the ground. Laboratory analyses were also performed to cietermine the behavior of long-lived radionuclides in the soil. The tests were conducted for plutonium-239, as well as for ruthenium-106, cesium-137, strontium-90, yttrium-90, and other fission products. Experiments were either conducted in batch mode, where the waste stream and soil were allowed to reach equilibrium, or in columns, where the process waste streams were passed through fixed volumes of soil. The experiments demonstrated that sorption or retention of radionuclides in Hanford Site soils depended on the initial radionuclide crncentrations in the waste stream; 
acidity $(\mathrm{pH})$ of the waste stream and soils; and the chemical characteristics of each radionuclide, namely whether the radionuclide is present as an anion or cation.

The different liquid wastes discharged to the ground at the Hanford Site had widely varying inventories and $\mathrm{pH}$ conditions (Parker 1954). The chemical form of the radionuclide influenced its behavior in the subsurface; cationic forms of radionuclides are more easily retained by soils. Of the radionuclides tested, plutonium-239 and cerium-144 were almost completely sorbed over a wide range of $\mathrm{pH}$ conditions. Cesium-137, strontium-90, and yttrium-90 were sorbed to different degrees, depending on the waste stream chemistry. Ruthenium-106 mixed with distilled water was sorbed under high pH conditions, but was mobile under acidic (low pH) conditions. Ruthenium-106 in waste streams from Hanford operations was found to be highly mobile and not sorbed by sediments. Based on field observations (ground-water monitoring), Parker (1954) noted that uranium forms complexes with other chemicals and is mobile. This observation was confirmed later near the 216-U-1 and U-2 cribs in the 200-West Area where uranium was found to be complexed (combined) with carbonate and was observed to be highly mobile (Delegard et al. 1986).

Brown (1957a) reported that laboratory experiments were performed with wastes from the process operations to determine volumes of wastes that could be discharged to the ground before contaminants in the soil column (unsaturated zone) would break through to the ground water. The laboratory researchers reported the results of soil-column experiments designed to evaluate breakthrough of cobalt-60.

Other tests performed before ground disposal of wastes included a 4-month field test designed to determine the infiltration rate of reactor coolant effluent disposed to the ground in an existing trench at the 100-D Area (Eliason and Hajek 1967). The field test included measurements of water elevations, temperature, and radionuclide concentrations in ground-water monitoring wells and river bank springs near the crib. The study demonstrated that large volumes of reactor coolant effluent could be disposed to the ground near the river without raising the water table to the ground surface. of the radionuclides investigated, phosphorous -32 and zinc-65 were retained by the 
sediments. Iodine-131 and chromium-51 were relatively unaffected by sediments and moved without being retained by the sediments between the crib and the river.

\subsection{INFLUENCES ON RADIONUCLIDE MOVEMENT AT HANFORD}

The movement of radionuclides in the unconfined aquifer at the Hanford Site is influenced by the pattern of natural recharge; the locations and volumes of artificial recharge resulting from waste-water discharges, which have changed with time; the distribution of aquifer properties, primarily hydraulic conductivity, within the aquifer; the starting and ending locations for contaminant flow paths; the chemical composition of liquid effluents; and the geochemical behavior of contaminants in Hanford ground water (Freshley and Graham 1988). While one or more of these factors can control the velocity of ground water or a contaminant at a specific location along a flow path, all may interact over the entire length of the particular flow path.

\subsubsection{Natural Recharge}

The pattern of natural recharge to the unconfined aquifer at the Hanford Site affects contaminant movement by changing the elevation of the water table. Natural recharge to the unconfined aquifer occurs as surface runoff from Rattlesnake Mountain and Umtanum Ridge to the south and west of the Site (Newcomb, Strand and Frank 1972), upward leakage from the lower basalt aquifers (Graham 1983), and direct recharge from precipitation.

Newcomb, Strand and Frank (1972) estimated that the surface runoff from uplands in and west of the Hanford Site is small. They observe that, for most years, flow in the upper Cold Creek and Dry Creek valleys is small and is measurable only during brief periods. The surface runoff in these highlands was thought to either evaporate or recharge the shallow aquifer in the valleys. Surface runoff that recharges the Cold Creek and Dry Creek valleys from irrigation of wine grapes and orchards in the Cold Creek Valley enters the Hanford Site as ground-water flow. Although this amount of recharge has not been measured directly, it has been estimated with numerical models of ground-water flow; specifically, Jacobsen and Freshley (1990) attempted to calibrate a two-dimensional model of ground-water flow in the unconfined 
aquifer at the Site. They estimate that the inflow boundary representing the Cold Creek Valley is contributing $311,000 \mathrm{ft}^{3} /$ day to the unconfined aquifer.

An upward hydraulic gradient between the confined and unconfined aquifers exists over much of the Hanford Site. Thus, recharge may occur as upward leakage from the confined aquifers to the unconfined aquifer (Dove et al. 1982). However, there is evidence that the hydraulic gradients have been reversed, and downward leakage has occurred around B Pond and Gable Mountain Pond near the 200-East Area as a result of increased hydraulic heads in the unconfined aquifer from discharge of waste water to the ground (Graham, Last and Fecht 1984; Jensen 1987; Early, Hall and Johnson 1988).

Recharge from precipitation drives contaminants downward through the unsaturated zone. Recharge to the unsaturated zone from precipitation has been the subject of a number of investigations at the Hanford Site. Gee and Heller (1985) examined past studies of unsaturated water flow done primarily by Hanford contractors (Atlantic Richfield Hanford Company, Rockwell Hanford Operations, and PNL) to determine whether there was a consensus on the mechanism of recharge to the unconfined aquifer by precipitation and to quantify the amounts.

Gee and Heller (1985) analyzed the results from deep (59 feet) lysimeter investigations in the 200 Areas and concluded that recharge is occurring and water is draining at the lysimeter site, although the drainage is slow. They calculated possible downward recharge rates of 0.1 to 1 inches per year $(\mathrm{in} . / \mathrm{y})$. At the same site as the lysimeter in the 200 Areas, an uncased well (drilled to 309 feet) was used to determine recharge. Gee and Heller (1985) calculated a range of possible recharge $2 i$ this well of 0.01 to $2 \mathrm{in} . / \mathrm{y}$, based on estimates of hydraulic conductivities.

Gee and Heller (1985) also attempted to estimate recharge in the unsaturated zone based on the movement of tritium from atmospheric fallout of offsite atomic weapons testing. Results from sampling unsaturated sediments near the 200-East Area during 1969 demonstrated that tritium attributable to offsite atomic weapons testing was found to depths of 16 feet. The investigators interpret these data as corresponding to the depth of maximum penetration of recharge since the early 1950s when thermo-nuclear devices were first 
tested with direct release of tritium to the atmosphere. Gee and Heller (1985) suggested that these data could also be consistent with steady-state recharge (calculated to be $0.8 \mathrm{in./y}$ ) for a period of 20 years.

Results from shallow lysimeter studies near the 300 Area between 1974 and 1984 have shown that precipitation is infiltrating below the root zone of vegetation established on top of the lysimeters (Gee and Heller 1985). Recharge has been estimated to range from 1 to $3 \mathrm{in./y}$ at a grass-covered site and has exceeded $2 \mathrm{in./y}$ at a bare soil site. A combination of coarse-textured soils, shallow-rooted plants, and above-normal precipitation during the time period have been identified as causes for recharge rates that are high, compared with other study locations on the Hanford Site.

Modeling studies at the Hanford Site have been helpful in estimating the effective recharge (Kirkham and Gee 1983). However, according to Gee and Heller (1985), recharge cannoi be accurately predicted with numerical models because key parameters, such as soil hydraulic properties and actual evapotranspiration, have not been measured in sufficient detail. Results of modeling studies have shown that for the expected climate, topography, and soils at the Hanford Site, recharge is in the range of 0 to $2 \mathrm{in./y}$. Jacobson and Freshley (1990) included areal recharge in the calibration of a twodimensional model of ground-water flow in the unconfined aquifer. Their estimate of the areal distribution of recharge from natural sources (precipitation and snow melt) is illustrated in Figure 4.8 .

Bierschenk (1957) identified sources of natural recharge to the unconfined aquifer other than ground disposal of waste water and recharge by precipitation. Natural recharge to the aquifer also occurs by subsurface inflow from the west (Cold Creek and Dry Creek valleys). Other natural recharge occurs at the base of Rattlesnake Mountain from several creeks that flow intermittently following heavy rain or melting snow. In addition, Bierschenk (1957) identified a zone of ground water near the Columbia River that is recharged by bank storage from the river during periods of high river flow. During more recent studies of the 100-N Area, Jensen (1987) and Gilmore, 


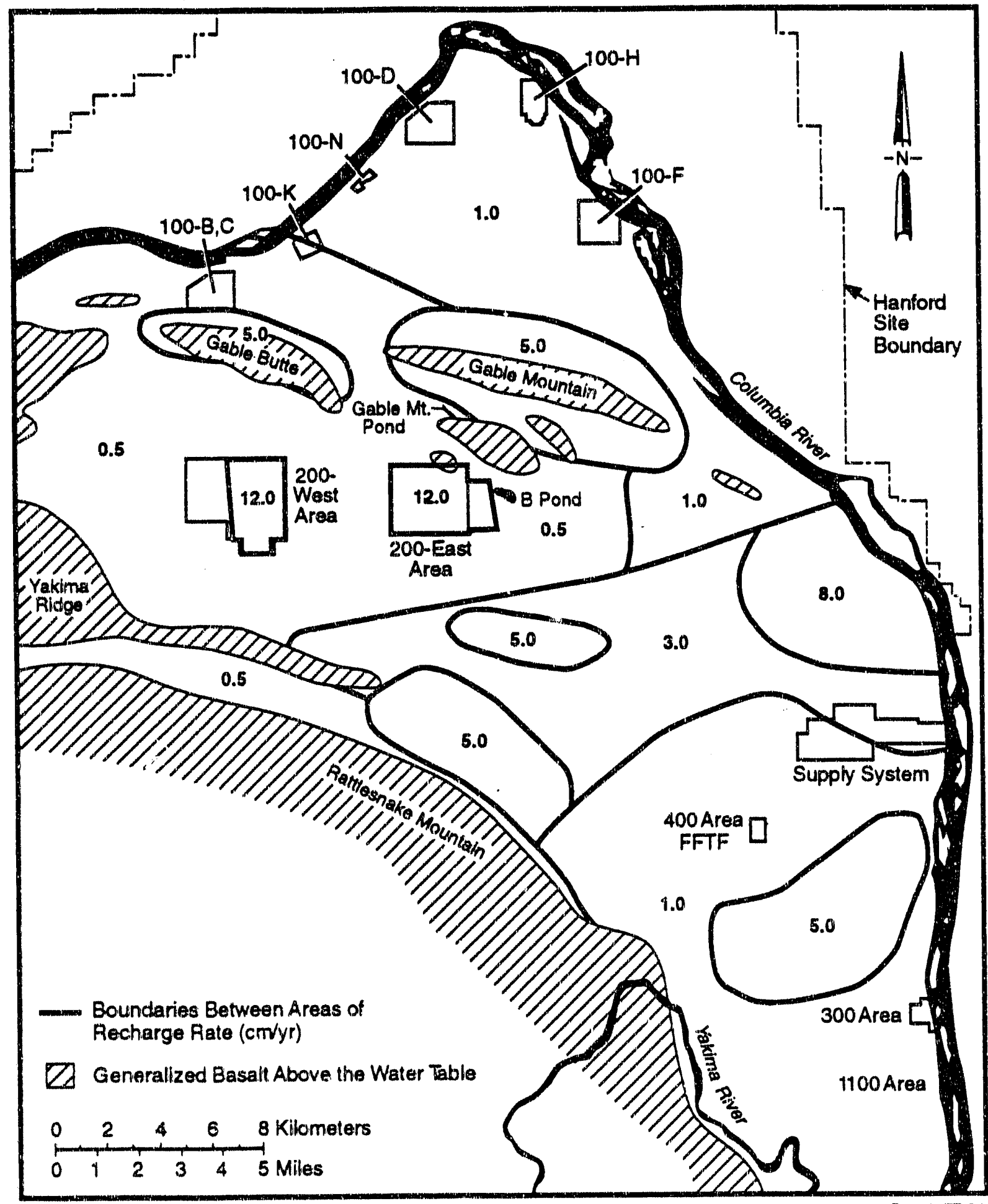

50192077.24

EIGURE 4.8. Distribution of Areal Recharge to the Unconfined Aquifer (after Jacobson and Freshley 1990) 
Borghese and Newcomer (1991) noted that fluctuation of the Columbia River had a significant impact on water levels in wells next to the river.

\subsubsection{Recharge from Liquid-Waste Disposal and Irrigation}

Artificial recharge to the unconfined aquifer occurs from large volumes of effluent discharged to surface ponds, cribs, and ditches in the 200 Areas (Graham et al. 1981). The major disposal ponds were $U$ Pond, B Pond, and Gable Mountain Pond (Figure 1.1). The effluent discharged to these facilities has artificially recharged the unconfined aquifer and created ground-water mounds (elevated areas of the water table) beneath both the 200-East and 200-West Areas (Graham et a1. 1981). This artificial recharge is estimated to exceed by an order of magnitude the natural recharge entering the Hanford Site as ground-water flow from the west (Graham et al. 1981). The flow direction, which was predominantly from west to east under pre-Hanford conditions (Newcomb, Strand and Frank 1972), is now highly variable within the 200 Areas (Figure 4.2).

Bierschenk (1957) summarized impacts to water levels in the unconfined aquifer from waste disposal operations. From 1944, when operations began, to June 1957, approximately 3 billion gallons of low-level radioactive waste water and 27 billion gallons of relatively uncontaminated cooling water were discharged to the ground. As of 1989, the total amount of liquids discharged to the ground had increased to 444 billion gallons (1.7 billion $\left.\mathrm{m}^{3}\right)$. (a) Changes in the water table were observed more than 15 miles away from the disposal areas; Bierschenk (1957) observed a net water-level increase in all wells on the Hanford Site from 1944 to 1957. Bierschenk (1957) observed more than an 80-foot rise in the water table beneath the 200-West Area and approximately a 20-foot rise in the water table beneath the 200-East Area.

The locations and volumes of effluent waste water discharged to the ground at the Site have changed with time (Graham et al. 1981). As a result,

(a) From an April 1991 presentation by Westinghouse Hanford Company, "Historical Perspective of Radioactively Contaminated Liquid and Solid Wastes Discharged or Buried in the Ground at Hanford." Available in the Public Reading Room, Federal Building, Richland, Washirgton. 
water levels in wells at the Site also have changed. Figure 4.9 illustrates the water-level history for a well near B Pond that responded to changing discharges to the pond.

The water-table changes for the period from 1944 to 1973 are documented by Kipp and Mudd (1974). Zimmerman et a1. (1986) documented historical changes of the water table between 1950 and 1980. Zimmerman et a1. (1986) found that the water-table changes migrated outward from the sources in the 200 Areas with time, reaching the Columbia River in the southeastern portion of the Hanford Site during the period 1965 to 1970. These water-table changes imply that the flow paths contaminants followed from sources in the 200 Areas al so changed with time. Water-table changes from 1980 to 1990, which show declining water levels in response to decreased discharges, were documented by Newcomer (1990).

Several facilities ana projects near Hanford have affected ground water at the site. Brown (1966) discussed impacts to unconfined and confined aquifers resulting from irrigation in the Columbia Basin Irrigation Project. beginning in 1950 and from construction and operation of the Priest Rapids and

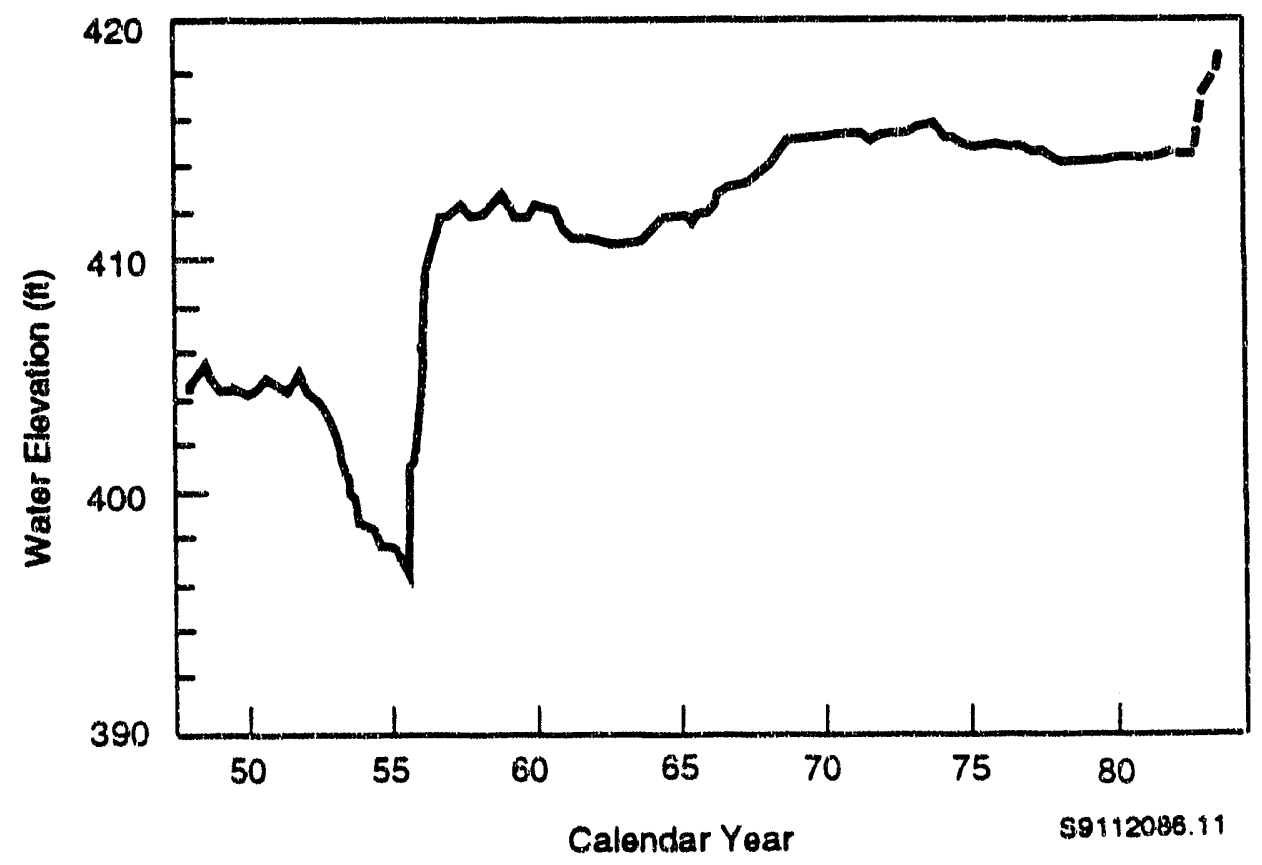

FIGURE 4.9. Water-Level History (Hydrograph) for We11 699-45-42 (Freshley and Graham 1988) 
Wanapum dams on the Columbia River upstream of the Hanford Site. The net effect from construction and operation of these facilities was to raise water levels in the unconfined aquifers in the Columbia Basin.

Hydraulic heads in the uppermost confined aquifers beneath the Hanford Site also increased in response to the irrigation and waste-water discharges. On the north side of the Columbia River opposite the Hanford Site (Wahluke Slope), water levels in the unconfined aquifer rose in response to the Columbia Basin Irrigation Project operations to the east and in response to the Priest Rapids Dam to the west. Figure 4.10 from Brown (1966) illustrates that, in the uppermost confined aquifer, the hydraulic gradients and resulting ground-water flow directions were radially inward toward the Hanford Site from irrigation to the east and Priest Rapids Dam to the west, then in a southeast direction toward Wallula Gap in response to impacts from Hanford operations and recharge from Rattlesnake Mountain.

More recent measurements of water levels in the unconfined aquifer on the west side of the Columbia River show a steep hydraulic gradient toward the river (Figure 4.11). The hydraulic gradient is also toward the river on the Benton County (Hanford) side. Thus ground water in the unconfined aquifer on both sides discharges to the river.

\subsubsection{Distribution of Aquifer Properties}

The distributions of aquifer properties, primarily hydraulic conductivity and aquifer thickness, influence ground-water flow and contaminant movement in the unconfined aquifer. The upper surface of the unconfined aquifer, the water table, is the Ringold Formation, which consists of sediments ranging in size from clay to gravel, and the Haniord formation, which consists of glaciofluvial sands and gravels ove'lying the Ringold Formation (Figure 4.1). The hydraulic conductivity, which describes the ability of the aquifer to transmit water, is more than an ordir of magnitude higher for the Hanford sediments than for the Ringold Formation (Graham et al. 1981).

The distributions of hydraulic conductivity and transmissivity (which is hydraulic conductivity multiplied by asuifer thickness) vary across the Hanford Site. Hydraulic characteristics of the unconfined aquifer have been determined by aquifer tests. These tests are generally conducted by pumping 


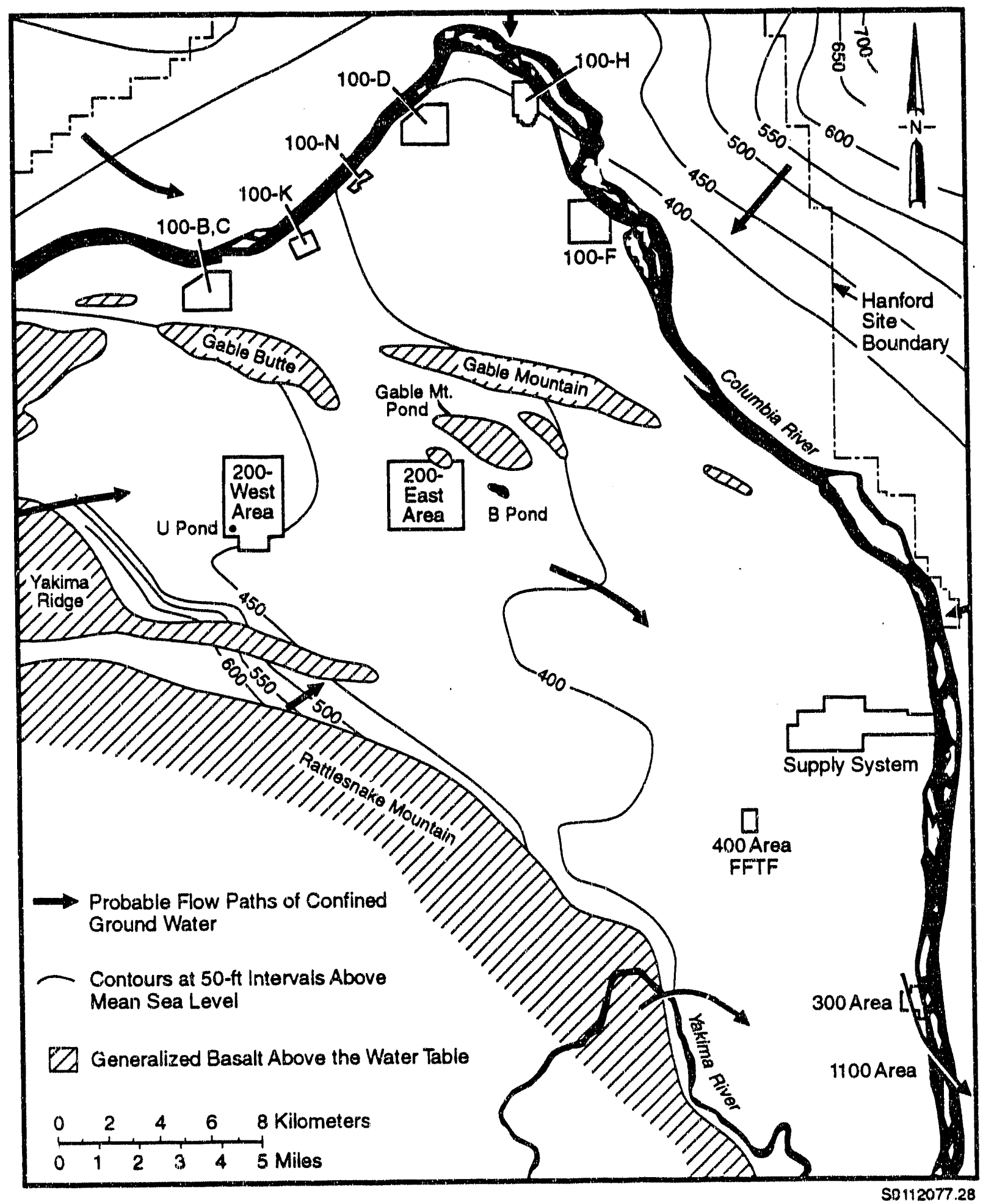

EIGURE 4,10. Hydraulic-Head Distribution in the Uppermost Confined Aquifer in 1966 (after Brown 1966) 


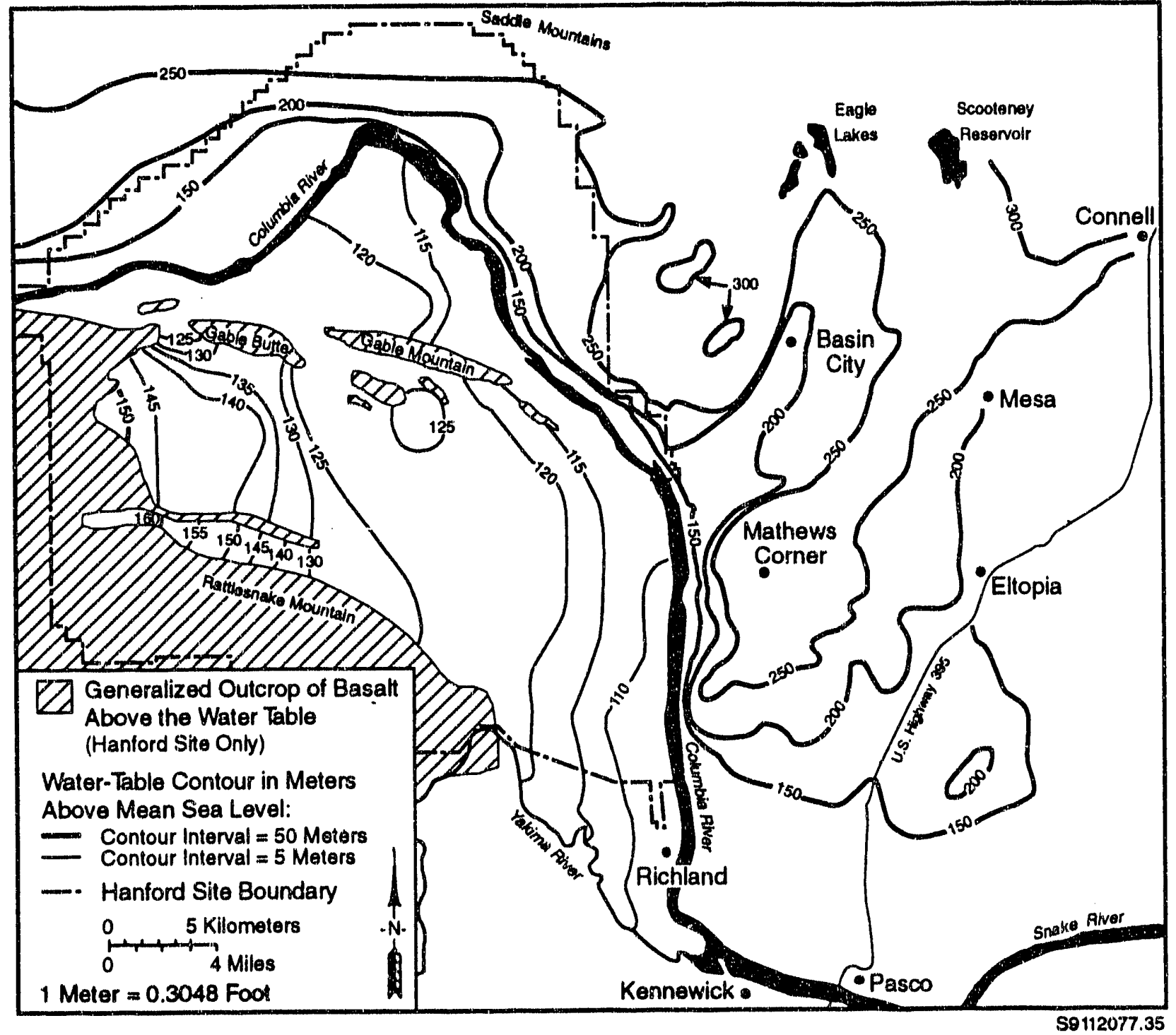

FIGURE 4.11. Water-Level Distributions for the Unconfined Aquifer in Benton and Franki in Counties During 1989 (Bryce et al. 1991)

ground water from the aquifer and observing the response in other nearby wells. Bierschenk (1957 and 1959b) and Kipp and Mudd (1974) summarized the results of aquifer tests conducted at the Site. The distribution of hydraulic conductivity in the unconfined aquifer was first estimated from point measurements (aquifer tests) by calibrating a two-dimensional model of ground-water flow (Cearlock, Kipp and Friedrichs 1975). This distribution was modified with a more recent calibration of a different two-dimensional model of the aquifer by Jacobson and Freshley (1990). Jacobson and Freshley (1990) applied 
an inverse calibration method to estimate the distribution of transmissivity in the unconfined aquifer. The results of the inverse calibration are illustrated in Figure 4.12.

The difference in aquifer properties between the Hanford and the Ringold formations is reflected in the ground-water mounds (circular pattern near the 200-East Area and "bowed" contour in the 200-West Area in Figure 4.1) beneath the 200-East and 200-West Areas (Graham et a1. 1981). By 1979, the water table beneath $U$ Pond had risen more than 85 feet as a result of waste-water disposal operations in the 200-West Area, which began in 1944. At the same time, the mound beneath B Pond near the 200-East Area had risen only 30 feet. Although receiving about the same total volume of waste water, the B-Pond mound is less than one half the height of the U-Pond mound. The heights of the two mounds differ because of the relative distribution of the Ringold and Hanford formations. In the 200-West Area, the unconfined aquifer is mainly in the Ringold Formation, but between the 200-East Area and the Columbia River, its upper part is in the Hanford formation.

The aquifer thickness and distribution of various units that compose the unconfined aquifer have a strong influence on contaminant movement at the Site. For example, the tritium plume originating in the 200-West Area has moved less than 4 miles from its sources, while the tritium plume originating in the 200-East Area has moved more than 16 miles from its sources and is discharging to the Columbia River (Jaquish and Bryce 1990; Woodruff et al. 1991). This difference in extent between the two contaminant plumes is the result of differences in the distributions of the Ringold and Hanford formations.

\subsubsection{Flow-Path Variation}

The large volumes of waste water discharged to the ground influence flow paths in the unconfined aquifer. Flow from the southeastern portion of the 200-East Area originally followed an easterly path and entered the Columbia River near the Hanford townsite. Because of changes in the pattern of the water table, mainly resulting from increased discharge to $B$ Pond, those flow paths now follow a more southerly pattern and discharge to the river south of the Supply System (Freshley and Graham 1988). However, tritium in the ground 


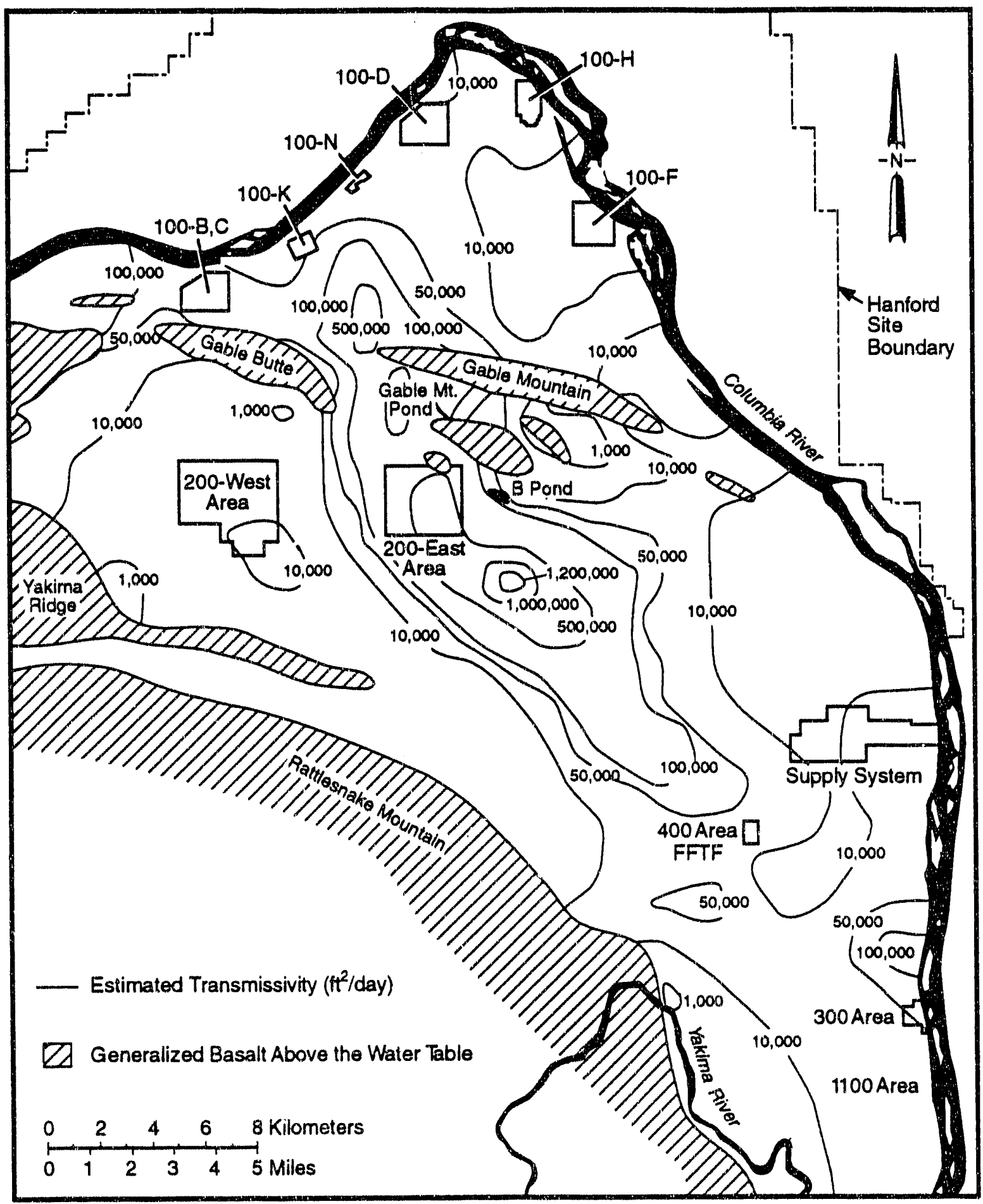

S9112077.25

EIGURE 4.12. Distribution of Transmissivity in the Unconfined Aquifer Resulting from the Inverse Calibration (after Jacobson and Freshley 1990) 
water is discharging to the river from between the Hanford townsite and the Supply system. The highest tritium concentrations are entering the river near the Hanford townsite (Jaquish and Bryce 1990; Woodruff et a1. 1991).

The flow paths that ground water and radionuclides from the 200 Areas will follow depends on where, with respect to the ground-water mounds beneath the 200-East and 200-West Areas (Figure 4.1), the water or radionuclides enter the unconfined aquifer. For example, the waste-water discharges to $B$ Pond have created a ground-water divide within the 200-East Area. Effluent discharged to the aquifer north of this ground-water divide will follow a flow path north through the gap between Gable Mountain and Gable Butte. Effluent discharged to the aquifer south of the ground-water divide will follow the southeasterly flow path previously described.

\subsubsection{Geochemical Properties}

The geochemical behavior of radionuclides also influences their movement in ground water at the Hanford Site. Tritium, which is present in high-volume liquid effluent, has a widespread distribution in the unconfined aquifer because it is not sorbed by the sediments composing the aquifer (Jaquish and Bryce 1990). Radionuclides such as strontium-90, cesium-137, and plutonium239,240 are attenuated or retained by sediments in the unsaturated zone through adsorption, chemical precipitation, and ion exchange (Routson 1973; Ames and $\operatorname{Rai}$ 1978). In addition, radionuclides such as strontium-90, cesium137, and plutonium-239,240 were concentrated in low-volume liquid effluent waste streams and typically do not have a widespread distribution at the Site, compared with the distribution of tritium. 


\subsection{GROUND-WATER MONITORING ON AND OFF THE HANFORD SITE}

Ground water at the Hanford Site has been monitored extensively for radionuclides since 1944 (Brown and Raymond 1962a). Ground water off the Hanford Site has also been monitored periodically to determine whether radionuclides have moved offsite.

\subsection{SCOPE OF MONITORING PROGRAM}

Most of the early ground-water monitoring data were collected from drilled test wells and farm wells that existed before the Hanford Site was established (Parker and Gamertsfelder 1945a). Gradual1y, the number of test wells that were sampled increased and evolved into the current monitoring program (Woodruff et al. 1991).

Haney (1961a) described the scope of the monitoring function performed by staff in the Chemical Effluents Technology Operation of the General Electric Company. The scope of the program was to monitor and investigate the impacts of waste disposal, from both past and future operations at the Hanford Site. Field investigations were conducted to determine the impacts from past operations, and iaboratory investigations were conducted to predict future behavior of contaminants that were introduced into the environment by waste-disposal operations. The intent of monitoring was to provide assistance and guidance to the operators of the reactors and reprocessing plants.

In addition to providing information to operators of Hanford Site facilities, the purpose of monitoring activities expanded to include determination of the distribution of mobile radionuclides and nitrate from 200-Area wastedisposal sites and to relate the distributions of these constituents to Site operations (Woodruff et a1. 1991). The unconfined aquifer at the Hanford Site was monitored much more extensively than the confined aquifers because it was affected more by Site operations and because it had the greatest potential for causing human exposures by use of wells or by ground-water discharge to the river. However, the confined aquifers were also monitored because they represented potential pathways for offsite migration of radionuclides.

\section{1}




\subsection{DESCRIPTION OF MONITORIMG TECHNOLOGY}

The technologies for ground-water monitoring at the Hanford Site included construction of wells, sample collection and analysis, and use of other measurement devices such as flow meters. As the technologies evolved and improved, the quality of data generated by the ground-water monitoring activities improved. To evaluate the potential for contamination and for detecting ground-water contamination, the early monitoring data are acceptable. However, more recent data are better for delineating plumes of specific radionuclides.

\subsubsection{Monit.oring Wells}

Monitoring welis were the primary means of collecting ground-water samples; very few (less than 130) springs exist on the Hanford Site, most of them on Rattlesnake Mountain (Schwab, Colpitts and Schwab 1979) and along the shoreline of the Columbia River (McCormack and Carlile 1985). More than 200 wells existed before the Hanford Site was established. Most were hand-dug farm wells (McGhan 1989). Including the pre-Hanford wells, over 3500 wells have been constructed at the Hanford Site. Some have been destroyed; as of January 1989, over 2900 wells existed at the Hanford Site (McGhan 1989). Approximately 1990 of these were drilled to ground water in the unconfined and confined aquifers. The remaining wells were used to monitor waste-disposal facilities in the unsaturated zone in the 200 Areas and were not drilled to the ground water.

Brown and Raymond (1962a, 1962b) provided general descriptions of the monitoring methods and concepts of ground-water flow that provided the basis for the monitoring program for the unconfined aquifer during the first 16 years of Hanford Site operations. Brown and Raymond (1962a) stated that some of the monitoring wells were drilled to the basalt bedrock, others to the first semi-impervious layer below the water table (generally a "blue clay" member of the Ringold Formation), and others to only a few tens of feet below the water table. Most of the wells were 6 or 8 inches in diameter, although some had diameters of 10 inches or more (McGhan, Mitchell and Argo 1985). Because the unconsolidated sediments the wells penetrated could not remain intact without support, most of the wells were constructed with carbon-steel 
casing (Raymond 1958). The casing was punctured with a mills knife perforator; generally, four or five perforations around the entire diameter of the casing and one round of perforations per foot were used. Some of the wells were perforated with a shaped charge system (barrel with steel-piercing bullets) because it was faster and less labor-intensive than the original mills knife method. Some of the wells were constructed with piezometers, which were smaller diameter tubes sealed at different depths below the water table (Essig 1971).

Wells constructed in the unconfined aquifer before the mid-1970s were perforated over the entire depth of the we11, although the possibility that contamination might stratify within the aquifer was recognized. Brown (1957c) described an investigation to determine the effects of geologic layering and density of waste discharged to the ground on the vertical distribution of radionuclides in the ground water. A "delayed-action depth-sampling device," designed to collect undisturbed water samples from different depths was used. The results of the investigation demonstrated that the contamination was stratified, with the highest concentrations near the bottom of the well.

Haney $(1960 c)$ described a second effort to determine the vertical variation of radionuclide concentrations within open wells in the unconfined aquifer. The results of this investigation, near the 216-BY cribs, also demonstrated that most of the wells showed higher concentrations near the bottom of the well than near the top. However, a later investigation by Eddy, Myers and Raymond (1978) demonstrated that maximum concentrations of radionuclides are near the top of the aquifer. Brown's (1957c) and Haney's (1960b) earlier observations of high contaminant concentrations at the bottom of wells probabiy resulted from differences in contaminant density within open well casings.

The locations, construction, and status of wells are summarized in reports that are periodically updated. Brown and Ibatuan (1958) summarized data on exploratory and monitoring wells constructed at the Hanford Site as of 1958. This document was updated by McGhan, Mitchell and Argo (1985) and 1ater by McGhan (1989) in summaries of "Hanford Wells." 
In January 1974, a plan was generated to upgrade the existing groundwater monitoring program on the Hanford Site (McGhan 1978). The program upgrade included lowering specially designed television cameras into the wells to inspect conditions, performing step-drawdown tests to evaluate aquifer response in the well, cleaning out all sampling wells, perforating well casings to eliminate stagnant water columns in wells, reducing long water columns in some wells with plugs to sample the upper portion of the unconfined aquifer, and installing well screens and submersible sample pumps where needed.

Cleanout of the wells consisted of removing silt and sand from the bottom of the casing and brushing rust and scale from the side of the casing. Steel casing walls were punctured with a mills knife where perforations were limited or nonexistent. Some wells were shortened or plugged by installing wooden plugs (approximately. 18 inches long), which were lowered with well-drilling tools; these plugs were left to swell overnight and bridge the casing. Cement grout was then placed on top of the wooden plug to provide a permanent seal. The lengths of wells were reduced because the study by Eddy, Myers and Raymond (1978) demonstrated that most of the contamination was found in the upper portion of the aquifer.

Between Apri1 1974 and December 1977, extensive remedial work (as described above) was done on 222 wells used for monitoring the unconfined aquifer. The results of the well remediation program are summarized in Table 5.1 (McGhan 1978). The changes indicated in the table refer to differences in concentrations of radionuclides measured in samples from the wells.

TABLE 5.1. Effects of Well Remediation from 1974 to 1977 (after McGhan 1978)

\begin{tabular}{|c|c|c|c|c|c|}
\hline \multirow{2}{*}{$\begin{array}{l}\text { Effect on } \\
\text { Measured } \\
\text { Concentration }\end{array}$} & \multirow[b]{2}{*}{$\begin{array}{l}\text { No. of } \\
\text { Weils }\end{array}$} & \multicolumn{4}{|c|}{ Action Taken } \\
\hline & & Plugged & Perforated & Developed & $\begin{array}{c}\text { Pump } \\
\text { Installe } \\
\end{array}$ \\
\hline efinite Change & 59 & 21 & 24 & 50 & 43 \\
\hline No Change & 91 & 40 & 21 & 81 & 78 \\
\hline Insufficient Data & 72 & 17 & 17 & 62 & 38 \\
\hline
\end{tabular}


In the table, "plugged" refers to shortening the water column by inserting a cement plug; "perforated" refers to puncturing the casing with a mills knife; and "developed" refers to pumping the wells to develop a clean filter of gravel near the openings in the well. More than one action was taken for some of the wells, so the numbers in the well remediation column do not equal the number of wells. Well remediation work has been included as part of Site-wide ground-water monitoring activities since 1977.

\subsubsection{Sample Collection}

Samples were collected at varying frequencies throughout the history of Hanford operations. Parker (1945) stated that water samples were collected from every available well at the Hanford Site during 1945 and analyzed for radionuclides. In the monthly report for March, Parker (1945) siated that 64 wells were sampled and analyzed weekly, and 15 wells were sampled monthiy during 1945.

Haney (1960a) indicated that the monitoring well sampling and analysis program was revised and a new sampling schedule put into effect in November 1959. The primary change was less frequent sampling of wells that were not in zones of existing contamination. Wells in contamination zones were also sampled less frequently, but the number of wells sampled and analyzed for specific radionuclides was increased. While the changes were made to reduce sampling and analysis costs, they were designed to maintain the integrity of the monitoring program.

Samples were collected by different methods. According to Brown and Raymond (1962a), most ground-water samples were collected at or just below the water table by lowering an unstoppered glass bottle in a stainless steel cage into the water. The sampling method was considered to be relatively fast and eliminated the problem of possible cross contamination from ground water at greater depths. Piezometers were sampled with a smaller diameter collection device or by airlifting, where compressed air was injected into the tube near the bottom, forcing water out the top. 
Special sampling equipment was developed at the Hanford Site to obtain water samples at depths below the water table. A depth sampler was developed specifically to collect samples from different depths (Brown and Raymond 1962a). The depin sampler consisted of an evacuated (pressure less than atmospheric) glass bottle fitted with a solenoid valve attached to a length of conduit. The device was lowered into the ground water to a predetermined depth until water inside the well casing, perturbed by intrusion of the sampling device, reestablished equilibrium with water in the aquifer. An electrical current then opened the solenoid valve, allowing the water to enter the bottle. The valve was then closed and the sample raised to the surface.

Currently, ground-water samples are collected according to documented sampling procedures (Jaquish and Bryce 1990). Most wells are fitted with submersible pumps and are sampled after sufficient time to allow temperature, $\mathrm{pH}$, and specific conductance to equilibrate. These parameters are easily measured physical and chemical characteristics of the water. This procedure is used to eliminate stagnant water in the wells and ensure that a sample representative of ground water near the well is collected.

The number of ground-water monitoring wells sampled at the Hanford Site continues to change with time in response to changing regulatory requirements (RCRA, CERCLA), to needs of the environmental surveillance program at the Site, and to movement of contamination in the ground water. Figure 5.1 illustrates the distribution of ground-water monitoring wells during 1989; this illustration is from Jaquish and Bryce (1990). The distribution reported in the most recentiy published environmental monitoring report (Woodruff et al. 1991) is similar.

\subsubsection{Sample Analysis}

Healy and Gamertsfelder (1945) described in detail the sample analysis procedure used in early monitoring activities. A 500-milliliter sample of water was evaporated and subjected to spectrographic analysis. Samples were also run through resins to collect radionuclides for analysis. The samples were measured for radioactivity over several days to detect changes in beta and gamma activities and to determine half-lives so that the radionuclides could be identified. 


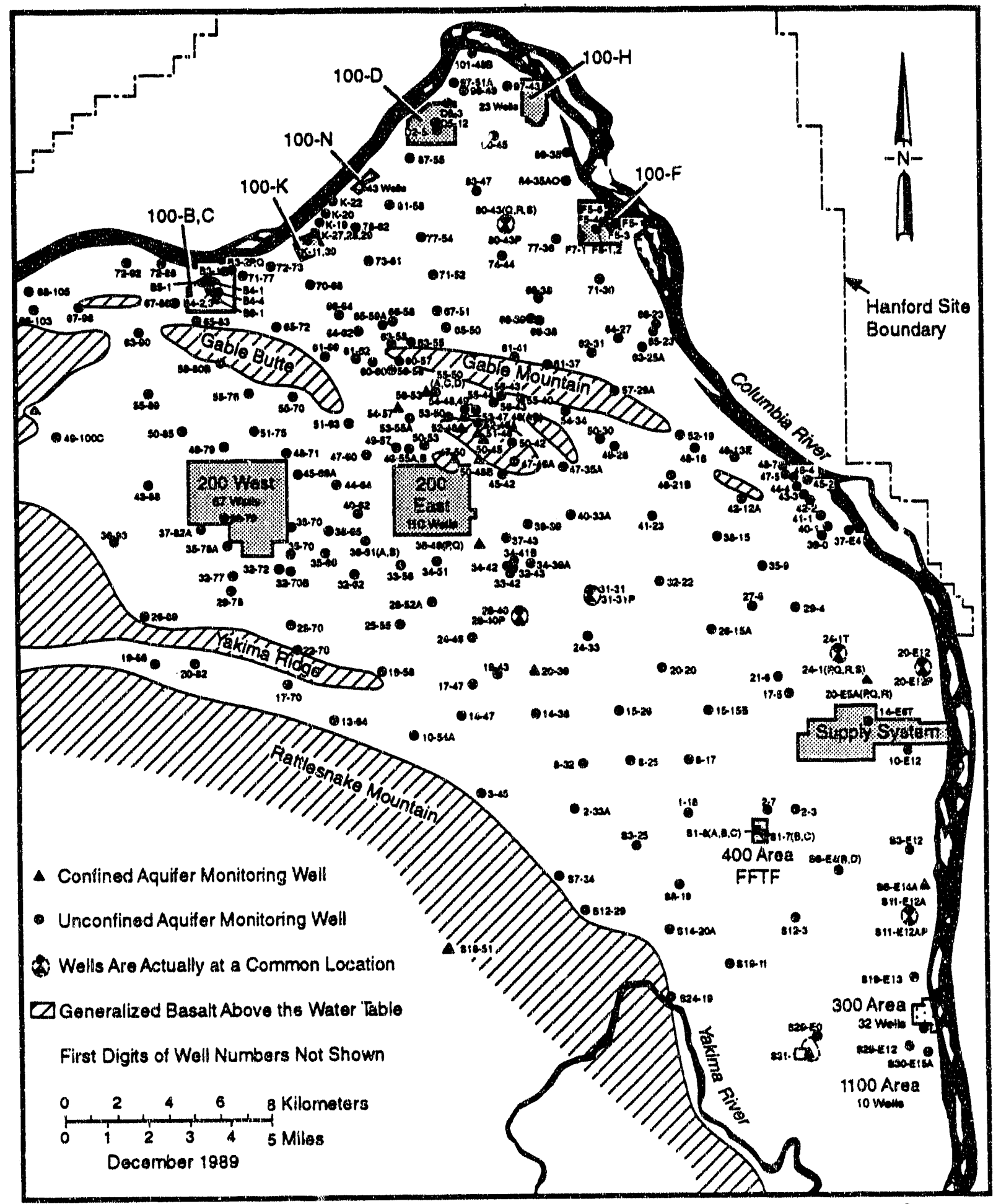

S9112002.1

LIGURE 5.1. Distribution of Ground-Water Monitoring Wells During 1989 (Jaquish and Bryce 1990) 
In 1945, the analysis procedure was to evaporate a 100 -milliliter sample and count the radioactivity for 5 minutes (Parker 1945). This procedure allowed detection of concentrations as low as $3 \times 10^{-4} \mu \mathrm{Ci} / \mathrm{L}(300 \mathrm{pCi} / \mathrm{L})$ for identified gross beta emitters.

Dupont (1945) also described methods and equipment used to collect and analyze water samples and other environmental samples during early operations of the Hanford Site. The original equipment for measuring radioactivity in water samples was determined to be unsatisfactory in 1945, and a considerable effort was initiated to improve it. A method for measuring gross beta activity by placing a small dish of exposed liquid below a mica window GeigerMueller tube was researched and developed.

Dupont (1945) noted that cross contamination between measurement of different samples was a persistent problem that was solved with only moderate success. The problems with early water sample collection and analysis methods resulted in sporadic measurement results during the 1940s and early 1950 s. However, the monitoring results described in Section 6 are still useful for interpreting the extent of ground-water contamination.

The method of analyzing ground-water samples changed between October and December of 1945. Instead of evaporating a 100-milliliter (0.1-1iter) sample, analysts evaporated a 500-milliliter (0.5-1iter) sample directly into a beaker and used acid washes to transfer the residue to a counting glass. This change in methods led to greater sensitivity (lower detection limit) in the measurements. Samples were collected from effluent discharges to nonitor contaminants discharged to the ground, from drinking-water supplies, and from wells intended to monitor the unconfined aquifer in general. By 1950, the detection limit for gross beta concentrations (Paas and Singlevich 1950d) was lowered to $1.0 \times 10^{-8} \mu \mathrm{Ci} / \mathrm{ml}(10 \mathrm{pCi} / \mathrm{L})$. Paas $(1951 \mathrm{~b})$ referenced a "Standard Procedures Manual of the Control Functions Analytical Group" containing descriptions of procedures for analyzing samples.

Parker (1946a) reported that transfer of the "water counting program" from the Cold Semi-Works Building to laboratories in the contaminated "Technical Building" exposed the system to potential contamination. Parker (1946a) stated that this situation would be investigated further and, if necessary, a 
special laboratory would be constructed to perform this work. Parker (1946d) reports that the Health Instruments Section laboratories were being moved to the U Plant Control Laboratory and two quonset huts in the 300 Area. However, he states that the U Plant laboratories had previously been contaminated with plutonium and a special laboratory for analysis of low-levels of radionuclides might be necessary.

Bierschenk (1959d) indicated that when gross beta activities in a wellwater sample exceeded $1 \times 10^{-4} \mu \mathrm{Ci} / \mathrm{ml}(100,000 \mathrm{pCi} / \mathrm{L})$, the sample was analyzed for cobalt-60, strontium-90, and cesium-137. The anaiytical detection limits for these isotopes were $4 \times 10^{-7}, 7 \times 10^{-8}$, and $5 \times 10^{-7}{ }_{\mu \mathrm{Ci}} / \mathrm{ml},(400,70$, and $500 \mathrm{pCi} / \mathrm{L}$.), respectively.

Haney (1959) listed analytical detection limits for different radionuclides, gross beta, and gross alpha (see Table 5.2). No explanation was provided for the different detection 1 imits for cobalt-60 reported by Bierschenk (1959d) and Haney (1959). The analytical detection limit for gross beta concentrations was lowered from $1.5 \times 10^{-7}$ to $8 \times 10^{-8} \mu \mathrm{Ci} / \mathrm{ml}$ (150 to $80 \mathrm{pCi} / \mathrm{L}$ ), effective September 22, 1959 (Haney 1959).

Brown and Raymond (1962b) reported that, as of 1962, gross-beta activity was deternined by evaporating 100 milliliter $(0.1$ liter) of the sample on a

IABLE 5.2. Analytical Detection Limits for Radionuclides as of September 22, 1959 (Haney 1959)

\begin{tabular}{|c|c|c|c|}
\hline \multirow{2}{*}{$\frac{\text { Radionuclide/Analysis }}{\text { Strontium-90 }}$} & \multirow{2}{*}{$\begin{array}{l}\text { Sample Volume } \\
\frac{\text { in ml (L) }}{300(0.3)}\end{array}$} & \multicolumn{2}{|c|}{$\begin{array}{l}\text { Detection Limit in } \\
\mu \mathrm{Ci} / \mathrm{ml}(\mathrm{pCi} / L)\end{array}$} \\
\hline & & $7 \times 10^{-8}$ & $(70)$ \\
\hline Cesium-137 & $50(0.05)$ & $5 \times 10^{-7}$ & $(500)$ \\
\hline Plutonium & $10(0.01)$ & $1 \times 10^{-7}$ & $(100)$ \\
\hline Cobalt-60 & $100(0.1)$ & $6 \times 10^{-7}$ & $(600)$ \\
\hline Uranium & $\ldots$ & $6 \times 10^{-9}$ & (6) \\
\hline Gross Beta & $100(0.1)$ & $8 \times 10^{-8}$ & (80) \\
\hline Gross Beta & $10(0.01)$ & $8 \times 10^{-7}$ & $(800)$ \\
\hline Gross Beta & $1(0.001)$ & $8 \times 10^{-6}$ & $(8000)$ \\
\hline Gross Alpha & $100(0.1)$ & $7 \times 10^{-9}$ & (7) \\
\hline
\end{tabular}


small stainless steel dish and counting the beta particles with a myiar endwindow, gas-flow, proportional counter. Medium to high concentrations of gamma-emitting isotopes such as cesium-137 and cobalt-60 were determined directly by gamma scintillation spectrometry using a 9 -inch sodium iodide crystal with a 3-inch well for a 500-milliliter (0.5-1iter) sample. For low concentrations of gamma-emitters, the samples were concentrated and chemically separated. All samples were analyzed routinely for gross-beta emitters; in addition, many samples were analyzed for uranium, cobalt-60, strontium-90, cesium-137, tritium, and ruthenium-106.

The routine detection limits for these radionuclides in 1962, along with required sample volumes, are listed in Table 5.3. In their report, Brown and Raymond (1962b) stated that the detection limits could be lowered, if necessary, by applying other, more expensive analytical methods.

Myers, Fix and Raymond (1977) described a program for quality control measures that was initiated in 1974. The purpose of the program was to ensure that the results of sample analyses were representative of the ground-water system beneath the Hanford Site. In addition to the well maintenance program previously described, PNL began sending blind and duplicate samples to an analytical laboratory for quality control. As of 1976, the analytical detection limits summarized in Table 5.4 were reduced.

IABLE 5.3. Routine Analytical Detection Limits for Radionuclides in 1962 (Brown and Raymond 1962b)

Radionuclide/Analysis
Gross Beta
Uranium
Cobalt-60
Strontium-90
Cesium-137
Tritium
Ruthenium- 106

\begin{tabular}{l}
$\begin{array}{c}\text { Sample Volume } \\
\text { in m }(L)\end{array}$ \\
\hline $100(0.1)$ \\
$0.1\left(1 \times 10^{-4}\right)$ \\
$100(0.1)$ \\
$375(0.4)$ \\
$50(0.05)$ \\
$1(0.001)$ \\
$100(0.1)$
\end{tabular}

\begin{tabular}{rr}
\multicolumn{2}{c}{$\begin{array}{c}\text { Detection Limit in } \\
\mu C i / m] \\
(\mathrm{pC} i / L)\end{array}$} \\
\hline $8 \times 10^{-8}$ & $(80)$ \\
$6 \times 10^{-9}$ & $(6)$ \\
$2 \times 10^{-6}$ & $(2000)$ \\
$6 \times 10^{-8}$ & $(60)$ \\
$5 \times 10^{-7}$ & $(500)$ \\
$1 \times 10^{-5}$ & $(10,000)$ \\
$2 \times 10^{-7}$ & $(20)$
\end{tabular}


IABLE 5.4. Analytical Detection Limits for Radionuclides Monitored in Ground Water at the Hanford Site During 1976 (after Myers, Fix and Raymond 1977)

\begin{tabular}{|c|c|c|}
\hline Radionuclide & \multicolumn{2}{|c|}{$\begin{array}{l}\text { Detection Limit } \\
\text { in } \mathrm{LCi} / \mathrm{ml}(\mathrm{pCi} / \mathrm{L})\end{array}$} \\
\hline $\begin{array}{l}\text { Gross Beta } \\
\text { (as Ruthenium-106) }\end{array}$ & 0.08 & (80) \\
\hline $\begin{array}{l}\text { Gross Alpha } \\
\text { (as Plutonium-239) }\end{array}$ & 0.017 & (17) \\
\hline Tritium & 1 & $(1,000)$ \\
\hline Coba7t-60 & 0.02 & (20) \\
\hline Strontium-90 & 0.03 & (30) \\
\hline Ruthenium- 106 & 0.06 & $(60)$ \\
\hline Antimony-125 & 0.06 & (60) \\
\hline Iodine-129 & $1 \times 1$ & $\left(1 \times 10^{-5}\right)$ \\
\hline Iodine-131 & 0.01 & $(10)$ \\
\hline Cesium-137 & 0.02 & $(20)$ \\
\hline
\end{tabular}

The methods currently used for sample analysis are listed in Appendix D of Jaquish and Bryce (1990). The detection limits for radionuclides monitored during 1989 are listed in Table 5.5.

\subsubsection{Other Measurement Devices}

Other measurement devices and methods were used to collect and analyze additional monitoring data. Raymond (1960) summarized field equipment and methods used to characterize ground water at the Hanford Site. Methods and equipment for aquifer tests, recorders for continuous water-level measurements, ground-water velocity measuring equipment, and tracer tests are described.

As wells were constructed, tests were performed to determine the hydraulic characteristics of the aquifer. Bierschenk (1959b) and Kipp and Mudd (1974) summarized the methods used and the results of aquifer tests conducted at the Hanford Site from 1944 to 1973. Stevens recorders were used 
TABLE 5.5. Analytical Detection Limits for Radionuclides Monitored in Ground Water at the Hanford Site During 1989 (Jaquish and Bryce 1990)

\begin{tabular}{|c|c|}
\hline Radionuclide & $\begin{array}{l}\text { Detection Limi } \\
\text { in } \mathrm{pCi} / \mathrm{L} \\
\end{array}$ \\
\hline $\begin{array}{l}\text { Gross Beta } \\
\text { (as Ruthenium-106) }\end{array}$ & 16 \\
\hline $\begin{array}{l}\text { Gross Alpha } \\
\text { (as Plutonium-239) }\end{array}$ & 4 \\
\hline Tritium & 300 \\
\hline Strontium-90 & 0.6 \\
\hline Iodine- 129 & $1 \times 10^{-6}$ \\
\hline Plutonium-239, 240 & 0.10 \\
\hline Uranium (natural) & 0.5 \\
\hline Technetium-99 & 15 \\
\hline Nickel-63 & 10 \\
\hline Carbon-14 & 20 \\
\hline
\end{tabular}

to collect information on continuous water-level variations in some wells (Raymond 1960). Water-level variations were most important in wells near the Columbia River and near effluent disposal facilities such as the 100-N Area (Eliason 1967a).

The movement of radioactive wastes through the unsaturated zone in the 200 Areas was monitored with gamma logging equipment (Raymond and McGhan 1964). Gamna logging was a predecessor to the borehole geophysical equipment currently used at the Site and consisted of a well probe, wire line with a surface winch, and recording equipment. The probe was cylindrical and consisted of a sodium-iodide crystal and associated electronics. The output from the probe was transmitted to a linear amplifier and then to an analyzer for recording data. The readings from the probe were recorded by a count rate meter and recorder. The sensitivity of the instrument was given as $5 \times 10^{-6} \mu \mathrm{Ci} / \mathrm{m} 1(5000 \mathrm{pCi} / \mathrm{L})$.

Based on gross gamma well logs, Raymond and McGhan (1964) provided a qualitative evaluation of radioactive contamination beneath waste sites. The method was used to estimate the magnitude and extent of contamination in the 
ground beneath the waste sites. Wells were logged periodically to obtain an indication of the rate of downward contaminant movement. During a 5-year period ending in 1964, well logging showed that wastes in the 200 Areas spread laterally and gamma emitters moved downward in the unsaturated zone at a rate of 1 to $2 \mathrm{ft} / \mathrm{y}$.

A vertical flow meter was developed for measuring vertical flow between different zones in wells (McCormack 1961). The flow meter was lowered into a well and sealed with packers (inflatable bladders) against the inside of the well casing. Vertical flow within the well, if any, was channeled through an orifice in the meter. A signal transmitted to the ground surface provided measurements of vertical flow with a sensitivity of about \pm 30 milliliters per minute. Measurements with the vertical flow meter were used to assist with interpretation of ground-water monitoring data from individual wells.

Raymond (1955) described an electrical conductivity method for estimating the in situ velocity in a well. The method was based on dilution and/or displacement of an electrolyte. Electrical current flow between two electrodes in a well was correlated with displacement of the electrolyte by fresh water entering the well and was related to ground-water velocity through an equation. Because effective porosity was not well characterized at that time, the velocity estimates were relative, rather than absolute.

The temperature of the ground water in the unconfined aquifer at the Hanford Site was also measured routinely (Brown and Raymond 1962b). Temperature me surement equipment consisted of a thermistor sensor, electrical wire line, measuring circuitry, and recorder. The instrument was lowered into the ground water in the unconfined aquifer. The temperature range that could be measured was about $10^{\circ} \mathrm{C}$ to $80^{\circ} \mathrm{C}$. Day-to-day accuracy of the instrument was $\pm 0.2^{\circ} \mathrm{C}$, and the instrument sensitivity was $0.1^{\circ} \mathrm{C}$. The average temperature of natural ground water in the unconfined aquifer is about $17^{\circ} \mathrm{C}$, while most of the cooling water and steam condensate discharged to surface ponds and cribs ranged from $50^{\circ} \mathrm{C}$ to $100^{\circ} \mathrm{C}$. The temperatures in individual wells were plotted on maps and contour lines drawn. An example from measurements in 1962 (Brown 1962b) is provided in Figure 5.2. The spread in temperature made thermal mapping a good method for determining the extent of impacts from ground 


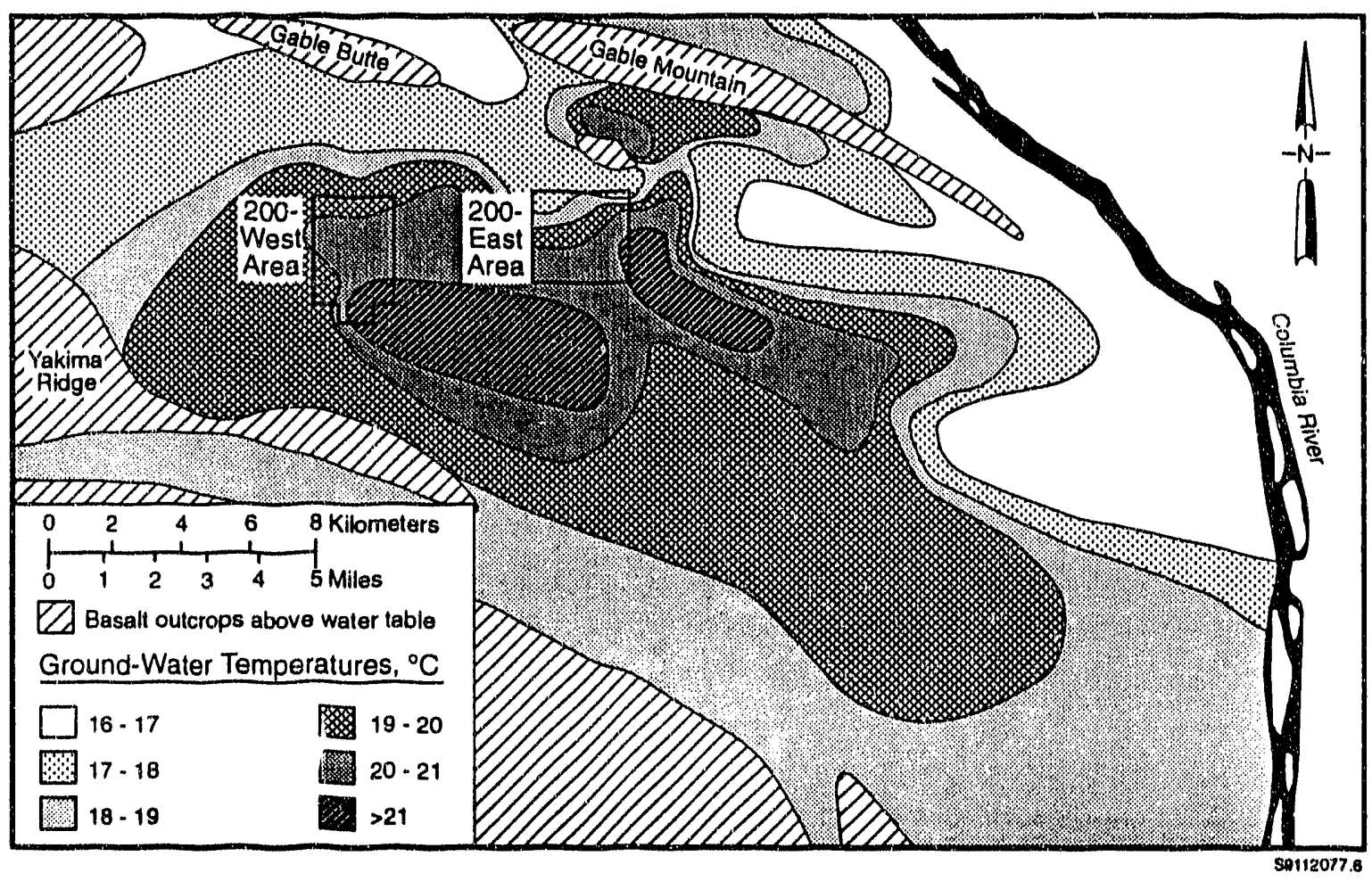

FIGURE 5.2. Ground-Water Temperatures in the Unconfined Aquifer During 1962 (after Brown 1962b)

disposal of wastes, although thermal contamination was associated with highervolume discharges than was most of the radioactive contamination. Large volumes of relatively uncontaminated process cooling water were discharged to ponds and swamps, while most of the radionuclides were discharged to cribs in low-volume waste streams. The ground-water temperature did not vary much from year to year, so temperature measurements were discontinued in 1978.

\subsubsection{Interpretation of Results and Supporting Studies}

Monitoring results were interpreted by first studying the analytical results for the water samples to determine which wells had contamination above the radionuclide detection limits (Brown and Raymond 1962a). The results were checked for mathematical errors or possible cross contamination that could have occurred during the analyses. Brown and Raymond (1962a) did not specify how the checks were performed or what criteria were used. If problems were 
identified, the sample was reanalyzed or the well was resampled. The monitoring results were compared with the contamination history of the well to establish whether the radionuclide concentrations were increasing or decreasing and to determine if the results were consistent with recent trends. After the results for individual wells were checked, the information was plotted on maps and used to draw contours.

Raymond et al. (1976) reported a change in the format of the annual monitoring reports. Quarterly and semi-annual maps that had previously shown contaminant concentrations (tritium, total beta, and nitrates) in the unconfined aquifer became annual maps illustrating average annual concentrations. The reporting format was changed because, after 1976, only minor changes in concentrations were typically observed each year, making annual reporting sufficient.

\section{Special studies to characterize ground-water flow were performed} periodically during Hanford Site operations. Brown (1957b) described results from 70 borehole dilution velocity tests and reported more than 200 measurements. These tests were conducted as part of an effort to characterize the hydrologic characteristics of the unconfined aquifer beneath the Hanford Site. Nearly $53 \%$ of the reported measurements were considered invalid because 1) well casings were improperly or inadequately perforated; 2) perforations were plugged; 3 ) the electrolytes were improperly mixed with well water, or 4 ) the volume of electrolyte resulted in density effects in the wel1. Brown (1957b) reported that laboratory studies were directed toward determining the usefulness of the borehole dilution method for determining aquifer characteristics. The borehole dilution method was later dropped in favor of other methods such as aquifer tests.

Brown (1957c) discussed development of a method for tracer testing with fluorescein dye. Using the dye, researchers measured velocities up to $770 \mathrm{ft} /$ day southeast of the 200-East Area. Later interpretations of the data were that the field tests had problems with cross-contamination between wells and that the velocities might have been artificially high.

Through tracer tests with fluorescein dye, Bierschenk (1959b) documented a velocity for ruthenium-106 from the 200-East Area to downgradient monitoring 
wells of about $160 \mathrm{ft} /$ day and 170 to $195 \mathrm{ft} /$ day. These velocities are very high, and Bierschenk cautioned that "precise determinations" of travel time could not be made at that time for Hanford because all of the influences on monitoring data at the Site were not quantified.

Bierschenk (1959c) included a summary on ground-water hydrology where an average "travel time" of 180 years for contaminants in the 200-East Area to reach the Columbia River is discussed. The calculation of travel time was based on field measurements of hydraulic conductivity from aquifer tests and construction of a water-table map with directions, rates, and volumes of ground-water flow. The "mean lateral path" was determined to be a broad arc trending south and east from the Separations Areas to the Columbia River.

Eddy, Prater and Rieger (1983) reported on the results of several supporting studies to the ground-water monitoring program. In the first of these studies, staff investigated the influence of variations in the level of the Columbia River on contaminant concentrations in the ground water. The results of this investigation indicated that concentrations in wells near the river were influenced by head changes in the ground water, changes that were induced by river-level variations. The other special studies described in this report consisted of investigation of the bottom of the unconfined aquifer near the Hanford townsite where part of the tritium plume discharges to the river, survey of wells with geophysical logging equipment, and update of the numerical model of the unconfined aquifer based on the Variable Thickness Transient (VIT) ground-water flow code (Kipp et al. 1976). 


\subsection{OFFSITE GROUND-WATER MIGRATION PATHWAY}

Assessment of the offsite ground-water migration pathway is separated into 1) a detailed evaluation of monitoring data for ground water both on and off the Hanford Site (Section 6.1); 2) a "bounding" estimate of the radionuclide discharge to the Columbia River for comparison with the results of river monitoring (Section 6.2); 3) a summary of river bank spring monitoring (Section 6.3$)$; 4) a brief evaluation of Columbia River monitoring because that is likely where radionuclides in the unconfined aquifer were discharged (Section 6.4); 5) a review of ground-water monitoring in Franklin County (Section 6.5); and 6) an assessment of potential radiation doses for the different components of the offsite migration pathway (Section 6.6). The evaluation of ground-water monitoring data in Section 6.1 is detailed because this is the first published comprehensive summary of historical monitoring results covering the more than 45 years of Site operations.

A considerable amount of ground-water contamination has resulted from the discharge of radioactive wastes to the ground at the Hanford Site iStenner et a1. 1988). This contamination has been monitored and reported in weekly, monthly, quarterly, and/or annual reports since Site operations began in 1944. The monitoring results indicate that many of the radionuclides are not mobile in Hanford ground water and have not moved very far from the source.

Radionuclide monitoring near the sources is conducted by the operating contractor at the Hanford Site; the most recent report, Serkowski and Jordan (1989), was published by the Westinghouse Hanford Company. Radiological moni-

toring for the entire Hanford Site was performed to protect drinking-water supplies and to determine the impacts of Site operations on the ground water. Table 6.1 relates radionuclides currently found in the ground water with site operations and waste management practices (Jaquish and Bryce 1990).

For the HEDR Project, the concern for the ground-water transport pa hway is with radionuclides that are mobile. Therefore, the ground-water monitoring data were reviewed for information on radionuclides that are mobile in ground water at the Hanford Site. The monitoring results indicate that tritium, ruthenium-106 (reported as gross beta during early years), technetium-99, and 
IABLE 6.1. Major Radiological Contaminants in the Ground Water and Their Link to Site Operations (after Jaquish and Bryce 1990; Woodruff et al. 1991)

Area

100

200

300
Facility Type

Reactor Operations

Irradiated Fuel Processing

Fuel Fabrication
Radionuclides

Tritium, cobalt-60, strontium-90

Tritium, ruthenium-106, cobalt-60, iodine-129, cesium-137, strontium-90, technetium-99, uranium, and plutonium Uranium and technetium-99

iodine-129 are mobile and have widespread distributions in ground water at the Site (Jaquish and Bryce 1990; Woodruff et al. 1991). In addition, these are the radionuclides for which the greatest amount of monitoring data are published.

One issue that has been raised at the Hanford Site is concerned with travel time for contaminants to migrate from waste sites in the 200-East Area to the Columbia River, specifically when the tritium plume from the 200-East Area reached the river. Travel time is the time required for ground water or specific concentrations of radionuclides to migrate from one location to another. The USGS (1987) summarized different interpretations of the groundwater monitoring data by Hanford Site researchers and by staff from an outside consulting firm, SEARCH Technical Services, Inc. The USGS estimated that the average travel time for tritium to migrate from the PUREX cribs in the 200-East Area to the Columbia River was slightly longer than 13 years. However, they determined that, because of uncertainties in interpreting some of the data, the travel lime for tritium to reach the river actually ranged from 10 to 20 years.

The travel time that is reported depends on the definition being used. The average travel time for contamination to reach a point in an aquifer such as a well is generally defined by arrival of half the maximum concentration in the well from a continuous cource (USGS 1987; Freshley and Graham 1988). The maximum concentration of tritium in wel1 699-40-1, which is near the river at the Hanford townsite, is approximately $225,000 \mathrm{pCi} / \mathrm{L}$ (Figure 6.1); half of the maximum concentration in this well is $112,000 \mathrm{pCi} / \mathrm{L}$. Therefore, the 


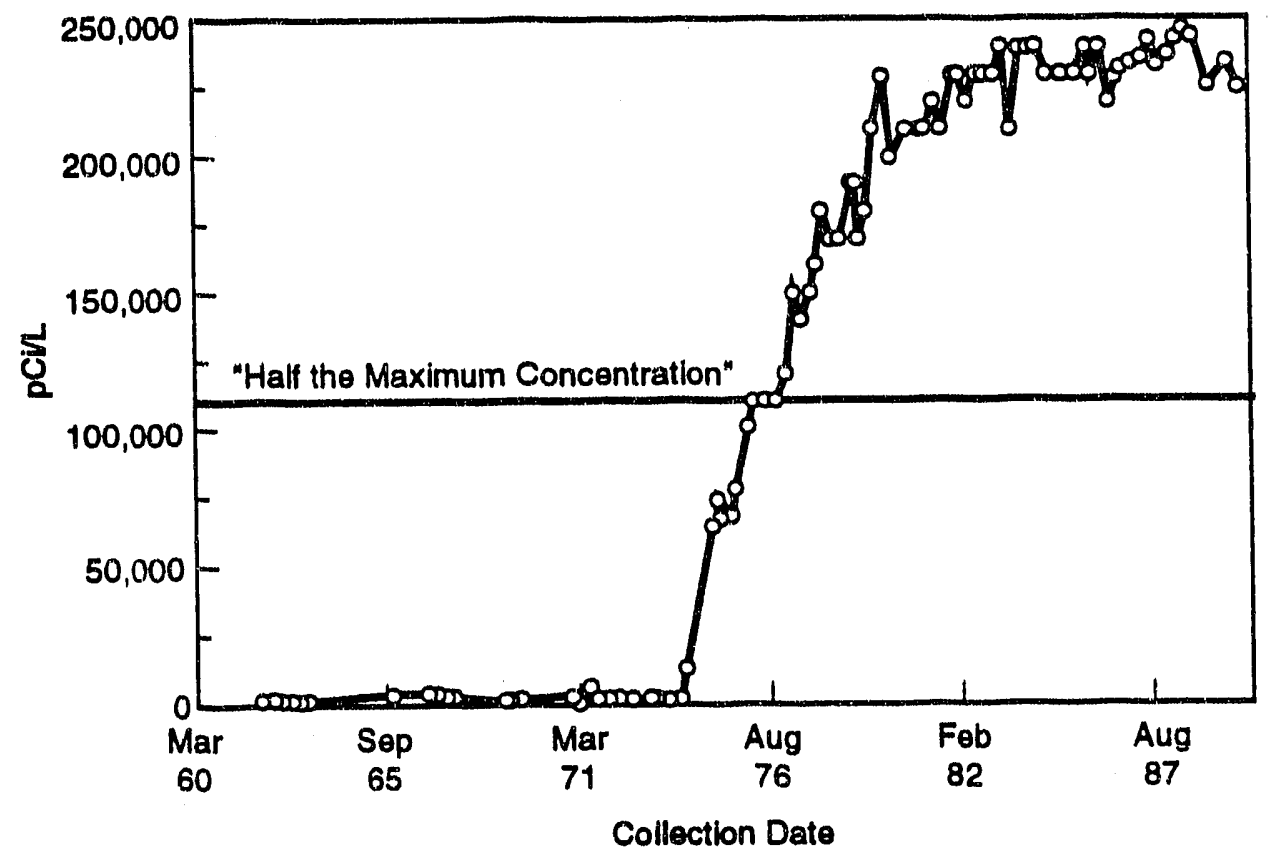

S8111080.14A

FIGURE 6.1. Concentration History for Tritium Measured in Well 699-40-1 (Woodruff et al. 1991)

concentration representing the average travel time for the tritium plume reached well 699-40-1 in 1976. The tritium plume probably reached the river within a year or two after that.

A key assumption made by the USGS for their travel-time estimate was that most of the tritium was discharged to the aquifer at the PUREX cribs after 1963 (USGS 1987). However, PUREX operations began in 1956, and arrival of the tritium plume at the river in 1976 to 1979 gives an average travel time of 20 to 23 years (Freshley and Graham 1988). Freshley and Graham (1988) summarize other travel-time estimates that have been made for the Hanford Site.

\subsection{RADIONUCLIDE MOVEMENT ON AND OFF THE HANFORD SITE}

This section is a summary of information on offsite migration that is contained in the monitoring reports as well as in other Hanford Site documents. Detailed summaries of the monitoring data and descriptions of the distributions of radioactive contaminants in the unconfined and confined 
aquifers at the Site are included in the monthly, quarterly, semiannual, and annual monitoring reports that were reviewed. This review was focused on determining how interpretations of the data changed with time and with changes in monitoring technologies. During review of the ground-water reports for the Hanford Site, a number of key "firsts" were identified. These and other significant activities are summarized in chronoiugical order in Table 6.2.

Radionuclide movement within and away from the 200 Areas is described in Section 6.1.1. Contaminant movement in the 100 Areas and the 300 Area is described in Sections 6.1 .2 and 6.1.3, respectively.

\subsubsection{Radionuclide Movement from the 200 Areas}

Discharge of processing wastes to the ground in the 200-East and 200-West Areas has contributed to the widespread contamination plumes observed in the unconfined aquifer. Radionuclides commonly found in the ground water from waste discharges in the 200 Areas were tritium, technetium-99, ruthenium-106, iodine-129, cesium-137, strontium-90, coba7t-60, antimony-125, uranium, plutonium, thorium-234, and protactinium-234 (Jaquish and Bryce 1990). The gross beta concentrations reported for over 30 years primarily reflect ruthenium-106 and cobalt-60 concentrations. Of the radionuclides 1 isted, tritium, technetium-99, ruthenium-106, cobalt-60, and iodine-129 have migrated outside the 200-Area boundaries. The occurrence and movement of gross beta, ruthenium-106, tritium, iodine-129, and other key radionuclides in ground water at the site are described in the following subsections of this report.

Gross Alpha, Gross Beta, and Ruthenium-106

Gross beta and gross alpha activities were reported early in the monitoring efforts at the Hanford Site because methods for determining the concentrations of specific radionuclides either were not developed or were too complex to be used for routine monitoring. In addition, during most of the early ground-watir monitoring accivities at the Site, grounc-water contamination either was not detected or concentrations vere close to the detection limit and the distibution varied from week to week. 


\section{TABLE 6.2. Chronology of "Firsts" for Ground-Water Monitoring at the Hanford Site}

Dccurrence/Event

Hanford Site Operations Began

First Report of Ground-Water Monitoring Acthities

Development of Improved Gross Radioactivity

Messurement Methods

First Reference to Ground-Water Contamination (Gross

Bota) Detectod in a Woll Samplo

Firat Known (Confirmed) Contamination of Ground Water

(361-B Roverse Woll in 200-Eaut Area)

First Discussion of Contaminated Ground-Water Movement

First Detertion of Ground-Water Contemination Outside

the 200-East and 200-West Aress

Firet Maps Showing Interpretod Extent of Known Ground-

Water Contamination (Based on Grose Beta Measuroments)

PUREX Operations Began

First Contoup Map of Contanination (Gross Bota)

Tritium Identified as a Byproduct of

Uranium Fission at the Hanford Site

Tritium Identified in Hantord Ground Water

Firet Arrival of Gross Beta Emitters at Well 699-24-23

(Approximatoly 4 Milos Southonet of the 2001-East Area)

First Summary of Grousnd-Water Temporatures

Measured in the Uncontined Aquiter

First Ruported Monltoring Results for Tritium in the

Unconfined Aquifer

First Map Showing Distribution of Tritium Corrtamination

in the Uncontined Aquiter

Firat Interpreted Arrival of Tritium at the Columbia River

PUREX Shut Down

Monttoring Wells Remodiatod to Shorten Water Column for Sampling

Firot Cooperativo Sampling with the USGS

USGS-Interpreted Arrival of Tritium at the Columbin River

Trittum Plume (Definad by 30,000 pCill. Trtium

Concentration Contourt Reached the Columbia River

PUAEX Restarted

First Arrival of Tritium fiom PUAEX at Downgradient Monitoring Wollis (NaAr Woll 689-24-23)

\begin{tabular}{|c|c|}
\hline Yoar & Reference \\
\hline 1944 & PNL (1991a) \\
\hline 1945 & $\begin{array}{l}\text { Parker and Gamertsfolder } \\
\text { (1945a) }\end{array}$ \\
\hline 1945 & duPont (1945) \\
\hline 1945 & $\begin{array}{l}\text { Parker and Gamertsfolder } \\
\text { (1945a) }\end{array}$ \\
\hline 1947 & $\begin{array}{l}\text { Earth Sciences Personnel } \\
\text { (1956a) }\end{array}$ \\
\hline 1958 & Parker (1956) \\
\hline 1956 & $\begin{array}{l}\text { Earth Sciences Personnel } \\
\text { (1956a) }\end{array}$ \\
\hline 1956 & $\begin{array}{l}\text { Earth Scionces Personnol } \\
\text { (1956a) }\end{array}$ \\
\hline 1956 & (a) \\
\hline 1958 & Elerechenk (1959a) \\
\hline 1962 & $\begin{array}{l}\text { Haney, Brown and } \\
\text { Rolsenauer (1962) }\end{array}$ \\
\hline 1858 & Albanesius 1950 \\
\hline 1861 & Hanoy (1961b) \\
\hline 1962 & Brown (1962b) \\
\hline 1952 & Brown (1962a) \\
\hline 1962 & Brown (1962b) \\
\hline 1982 & Brown and Haney (1964) \\
\hline 1972 & PNL (1987) \\
\hline 1974 & McGhan (1978) \\
\hline 1975 & $\begin{array}{l}\text { Myors, Fix and Raymond } \\
(19 \mathrm{~m})\end{array}$ \\
\hline 1976 & JSGS (1887) \\
\hline 1977 & Myors (1978) \\
\hline 1983 & PNL (1987) \\
\hline 1985 & PNL (1987) \\
\hline
\end{tabular}

(a) From an April 1981 presentation by Westinghowse Manford Company, Hilotorical Porspective of Radioectively Containinated Liquid and Solid Waster Diacharged or Buriod in the Ground at Hantord." Availuble in the Pubillc Reading Room, Federal Building, Richland, Washington. 
Most of the early ground-water monitoring activities at the Hanford Site were conducted to detect radionuclides in drinking-water supplies. A few of the pre-Hanford farm wells and test wells at the Site that were not used for drinking water were, however, monitored for radionuclides.

During 1945, sporadic concentrations of gross beta emitters were detected in wells at the Hanford Site (Parker and Gamertsfelder 1945a). The first report of ground-water monitoring activities at the Site was for the week ending February 23, 1945. The weekly report includes mention of result.s from a site survey reporting loss of liquids from the 241-T retention basin to a circular depression approximately 200 feet across. Measurable levels of radiation (1.1 millirem per hour [mrem/hr] gamma) were reported. According to the report, no contamination was found in the ground water which means ground-water samples had been collected and analyzed.

The next discussion in Parker and Gamertsfelder (1945a) regarding groundwater monitoring activities was for the week ending Apri1 6, 1945. The site survey group reported that sampling of wells had been "placed on a more vigorous basis," although no specifics were provided for either the new or previous schedules. No ground-water contamination was reported during that week.

The report for the week ending April 20, 1945, includes separate listings of survey results: 1) water and waste monitoring, 2) air monitoring, and 3) grcund contamination. No radioactivity was reported in the well monitoring the 241-T retention basin contamination. The report includes a statement that no contamination had been found in any source of potable water at the Site, which likely included both ground-water and surface-water sources.

The first reference to contamination potelitially found in ground water is in the report for the week ending July 27, 1945 (Parker and Gamertsfelder 1945a). Gross beta contamination in ground water was detected at $1.3 \times 10^{-4} \mu \mathrm{Ci} / \mathrm{L}(130 \mathrm{pCi} / \mathrm{L})$ in a well at "Ranch 13," which was located between the 200 Areas and the 100-B Area. The weekly report includes a statement that it was not known whether this measurement represented true ground-water contamination or resulted from cross-contamination of the water sample with surface contamination. 
During the remainder of 1945, ground-water sampling focused on detecting radionuclides in drinking water at the Hanford Site. Sporadic measurable concentrations of gross alpha and gross beta emitters were reported in Parker and Gamertsfelder (1945a, 1945b). Measurable concentrations of gross beta emitters were reported in the B-Y well and in wells at Ranch 13, White Bluffs, Columbia Camp, the Hanford townsite, Richland, and Benton City (Figure 6.2). However, a11 of the reported concentrations were only slightly above the detection limits achievable during 1945.

Detectable concentrations of gross beta emitters were observed in different wells during this reporting period. No one well consistently had concenirations above the detection limit. The maximum reported gross beta concentration during 1945 was $8.7 \times 10^{-4} \mu \mathrm{Ci} / \mathrm{L}(870 \mathrm{pCi} / \mathrm{L})$ at the Ranch 13 well during the week ending November 7, 1945 (Parker and Gamertsfelder 1945a, 1945b).

Most of the monthly reports for 1945 (Parker 1945) included a statement that no pollution of well water by radioactive wastes was evident. Because radioactivity observed in well water at Ranch 13 was attributed to airborne sources and cross-contamination of the water samples, all of the sporadic detections of contamination described in the weekly reports during 1945 were interpreted to be the result of these sources of contamination.

The same trend of sporadic measurement of detectable concentrations of gross beta emitters continued during 1946 (Gamertsfelder 1346a-j; Parker 1946a-c, 1947a-c). Detectable concentrations of gross beta emitters were observed in the B-Y well and wells in Richland, Kennewick, the Hanford townsite, White Bluffs, Ranch 13, the Benson Ranch, and the 300 and 3000 Areas north of Richland. During 1946, an average of 187 samples was collected each month from surface-water and ground-water sources used to supply drinking water. The minimum number of samples collected in a month during 1946 was 107 and the maximum was 391 .

During 1948, the number of samples collected from surface-water and ground-water sources used to supply drinking water each month averaged 326, with a minimum of 241 and a maximum of 375 (Singlevich 1948a-i; Healy 1948). In addition, the reports for 1948 include results of sampling 11 to 15 test 


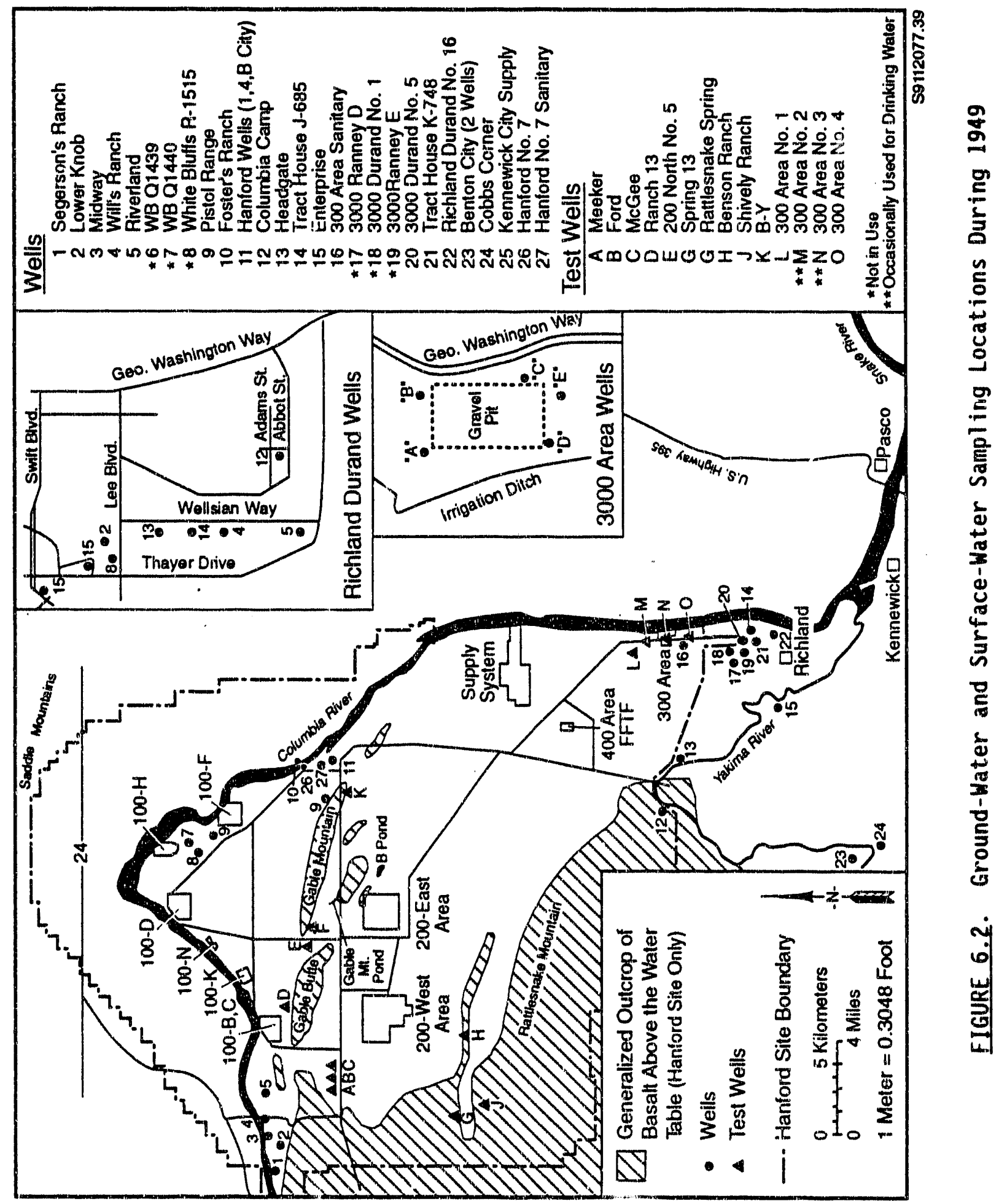


wells not used to supply drinking water. With one exception, gross beta concentrations were below the detection limits in both the drinking-water sources and test wells. One sample from a well in the 300 Area had a gross beta concentration of $5.8 \times 10^{-5} \mu \mathrm{Ci} / \mathrm{L}(58 \mathrm{pCi} / \mathrm{L})$, only slightly above the $5 \times 10^{-5} \mu \mathrm{Ci} / \mathrm{L}(50 \mathrm{pCi} / \mathrm{L})$ detection limit.

During the last quarter of 1948,1011 samples were collected from drinking water originating from surface-water and ground-water sources at the Hanford Site and analyzed for radioactive contamination (Singlevich and Paas 1949a). Ninety-nine samples were collected from test wells at the Site. Approximately $1 / 5$ of the samples were 12 liters, rather than the 500-mi11iliter (0.5-1iter) samples normally collected. The number of samples from each source varied from 5 per week to 1 per month, depending on the location of the source, the probability of that source being contaminated, and the concentration trends observed in previous analytical results.

During 1949 and 1950, the number of samples collected from test wells and analyzed for radionuclides increased (Singlevich and Paas 1949b; Paas and Singlevich 1950a-d; Paas 1951a). The detection limit for gross beta emitters was lowered to $10 \mathrm{pCi} / \mathrm{L}$. Concentrations of gross beta emitters were reported above the detection limit (up to $117 \mathrm{pCi} / L$ ) in wells monitoring the unconfined aquifer in north Richland during this time. Uranium concentrations were above the detection limit in wells at Richland, Benton City, and the 300 Area.

In addition to the Hanford Site and Richland wells, 25 samples were collected from irrigation wells located northeast of the Site during the first quarter of 1950 (Paas and Singlevich 1950c). All of the samples collected had gross beta concentrations less than the detection limit of $10 \mathrm{pCi} / \mathrm{L}$.

During 1951, zones of contamination in the 200-East and 200-West Areas were identified and monitored by analyses for radioactivity and nitrates (Mickelson 1952). These measurements were made to determine the rate of movement, diffusion (dispersion), and behavior of contaminants in the ground water. No specifics were provided in the report for the type or extent of contamination observed, although it was most likely gross beta activity. 
During 1951, the number of drinking-water and test-well samples collected each month continued to increase. The average number of drinking-water samples collected each month during 1951 was 1005, and the average number of test-well samples collected was 250 (Paas 1951b, 1951c; Paas 1952a). Detectable concentrations of alpha emitters (natural uranium) were observed in wells at Benton City and Richland. During the fourth quarter of 1951, an additional 48 wells drilled by staff in the Geology Group were added to the sampling network (Paas 1952a).

During 1952 and 1953, the patterns of gross alpha and gross beta concentrations remained similar to those observed in previous reporting periods (Paas 1952b, 1952c; Paas 1953a-e). Most of the gross beta concentrations were below the $5 \times 10^{-8}{ }_{\mu} \mathrm{Ci} / \mathrm{ml}(50 \mathrm{pCi} / \mathrm{L})$ detection 1 imit during this reporting period. During the third quarter of 1953, trace amounts of contamination by gross beta emitters were observed in we11 699-32-77, with an average concentration of $9 \times 10^{-8} \mu \mathrm{Ci} / \mathrm{ml}(90 \mathrm{pCi} / \mathrm{L})$ and a maximum concentration of $1.9 \times 10^{-7} \mu \mathrm{Ci} / \mathrm{ml}(190 \mathrm{pCi} / \mathrm{L})$ (Paas 1953e).

The first discussion of the movement of contaminated ground water was in 1956. Parker (1956) discussed movement of contaminated ground water southeastward from cribs receiving scavenged waste. The contamination probably consisted of gross beta emitters. A velocity associated with this contamination was estimated to be an average of $36 \mathrm{ft} /$ day. These measurements were compared with borehole dilution velocity measurements conducted in the same general area and were found to be in agreement.

Parker (1956) estimated that the travel time for contamination to move 13 miles from the 200-East Area to the Columbia River was 5 years. Parker (1956) stated:

"The local measurements of actual rate of ground-water movement are higher than one would have believed possible under the older methods of study. They have been amply verified now by alternative methods. In brief, we can be sure that some radioactive wastes can trave? 13 miles underground to the Columbia River in less than 5 years. Five years ago, it was believed that the realistic traveltime was about 1000 years; an operational philosophy was built around the apparently safe assumption that 50 years was the minimum time." 
The Earth Sciences Unit monthly report for January 1956 recorded the first measurement of ground-water contamination outside the 200-East and 200-West Areas (Earth Sciences Personnel 1956a). Earth Sciences Personnel (1956a) identified the period between 1947 and 1948 as the time when the first known contamination of the ground water occurred in the Separations Area at the 361-B reverse well site, which received wastes from B Plant. The extent of contamination in the 200-East and 200-West Areas during January 1956 is illustrated in Figures 6.3 and 6.4 , respectively. The extent of contamination illustrated in these figures is presumably based on gross beta measurements, but the specific radionuclide was not listed. In addition, the concentration limit used to specify the extent of contamination was not listed.

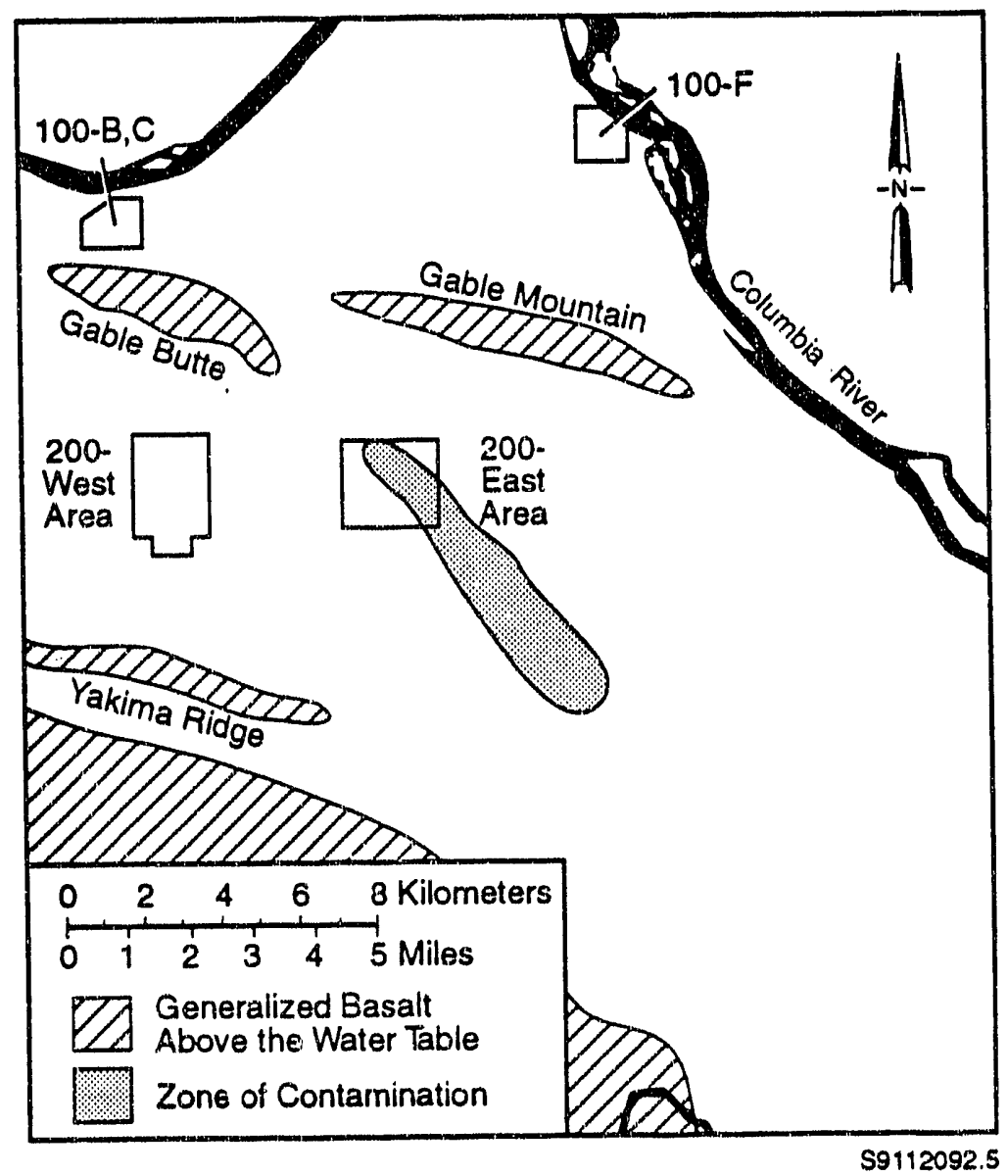

FIGURE 6.3. Approximate Extent of Known Ground-Water Contamination from the 200-East Area During January 1956 (after Earth Sciences Personnel 1956a) 


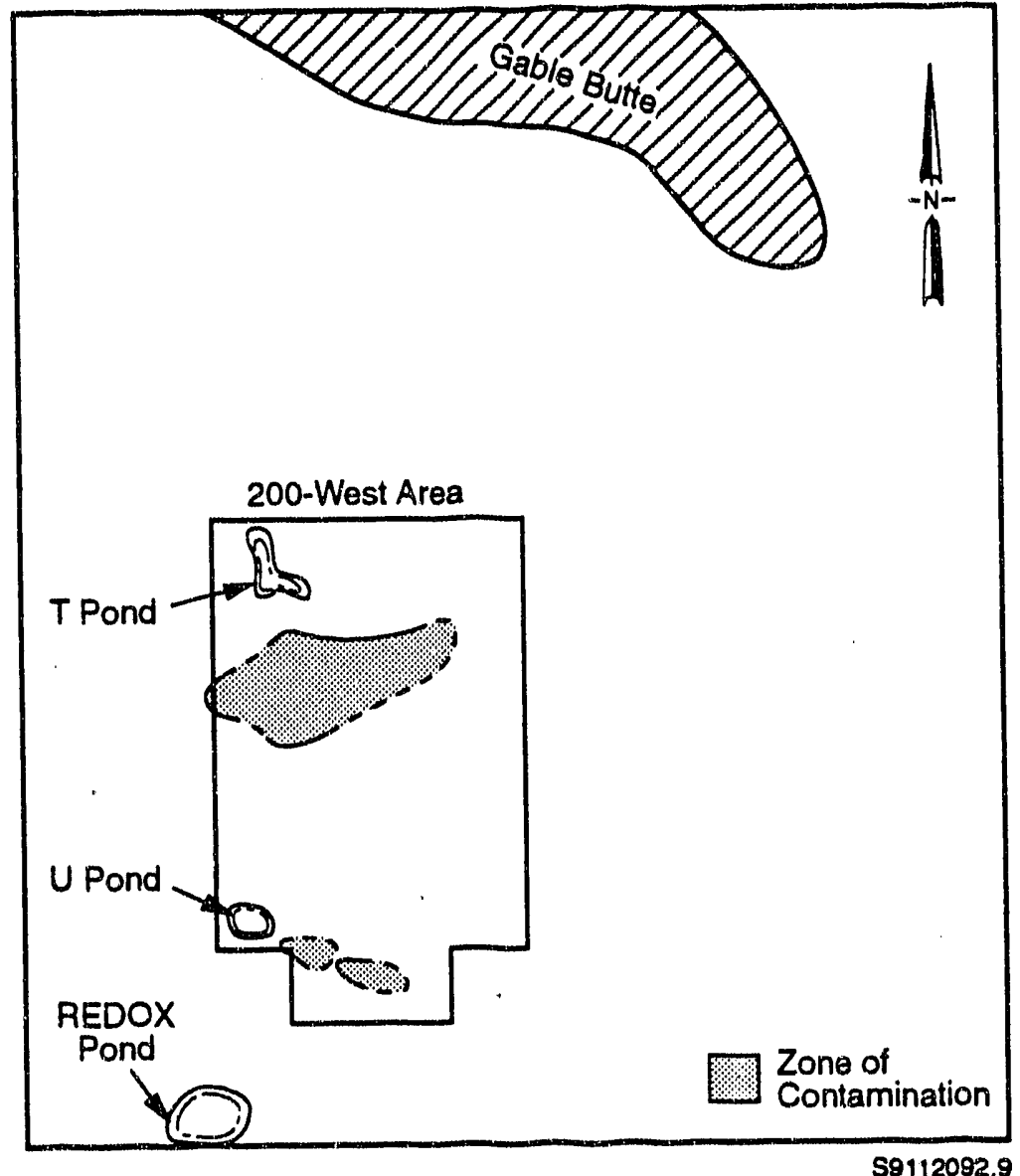

FIGURE 6.4. Approximate Extent of Known Ground-Water Contamination from the $=00$-West Area During January 1956 (after Earth Sciences Personnel 1956a)

The Earth Sciences Unit monthly report for April 1956 (Earth Sciences Personnel 1956b) documented that contamination southeast of the 200-East Area had spread extensively from the previous month. The sampling and analysis results were interpreted to indicate that radioactive contamination had moved as far away as 13 miles southeast from sources in the 200-East Area (Figure 6.5). This interpretation was based on gross beta measurements, as we 11 as measurements of sodium and nitrate that were discharged to the ground along with the radioactive contamination. Interpretation of the distribution of contamination in ground water beneath the 200-West Area (Figure 6.6) changed significantly from the previous reporting period, but it still did not 


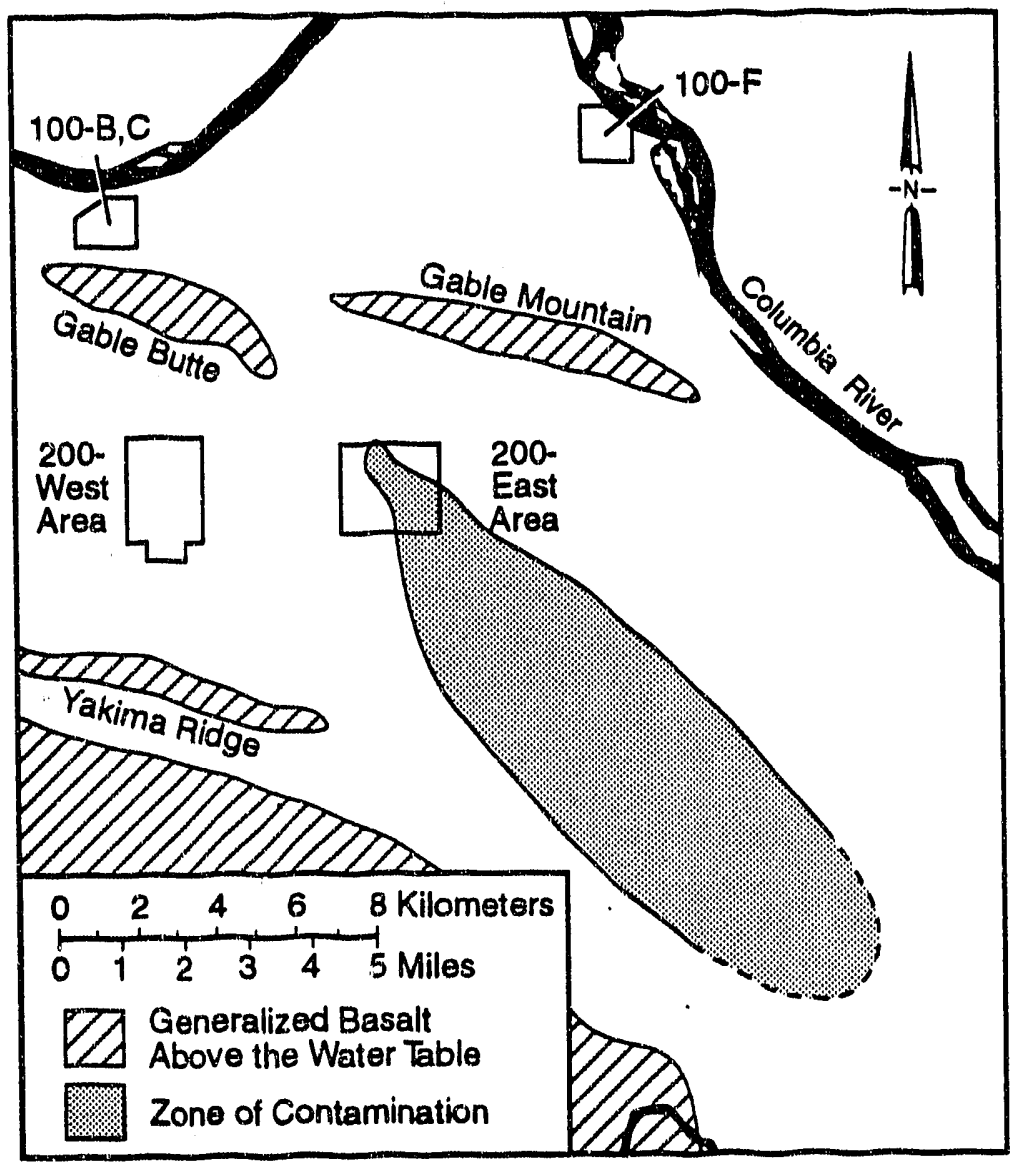

59112092.6

FIGURE 6.5. Approximate Extent of Known Ground-Water Contamination from the 200-East Area During Apri1 1956 (after Earth Sciences Personnel 1956b)

illustrate that contamination had migrated significantly downgradient. No indication was provided of the concentration limit or contaminant used to define the extent of contaminatior.

Brown (1957a) replaced the earlier Earth Sciences Personnel monthly waste disposal monitoring reports. A different interpretation of the water-table configuration in the 200-East Area resulted in a finding that the extent of ground-water contamination during July, August, and September 1956 (Figure 6.7) was smaller than previously reported (Brown 1957a). The distribution of ground-water contamination beneath the 200-West. Area had not changed 


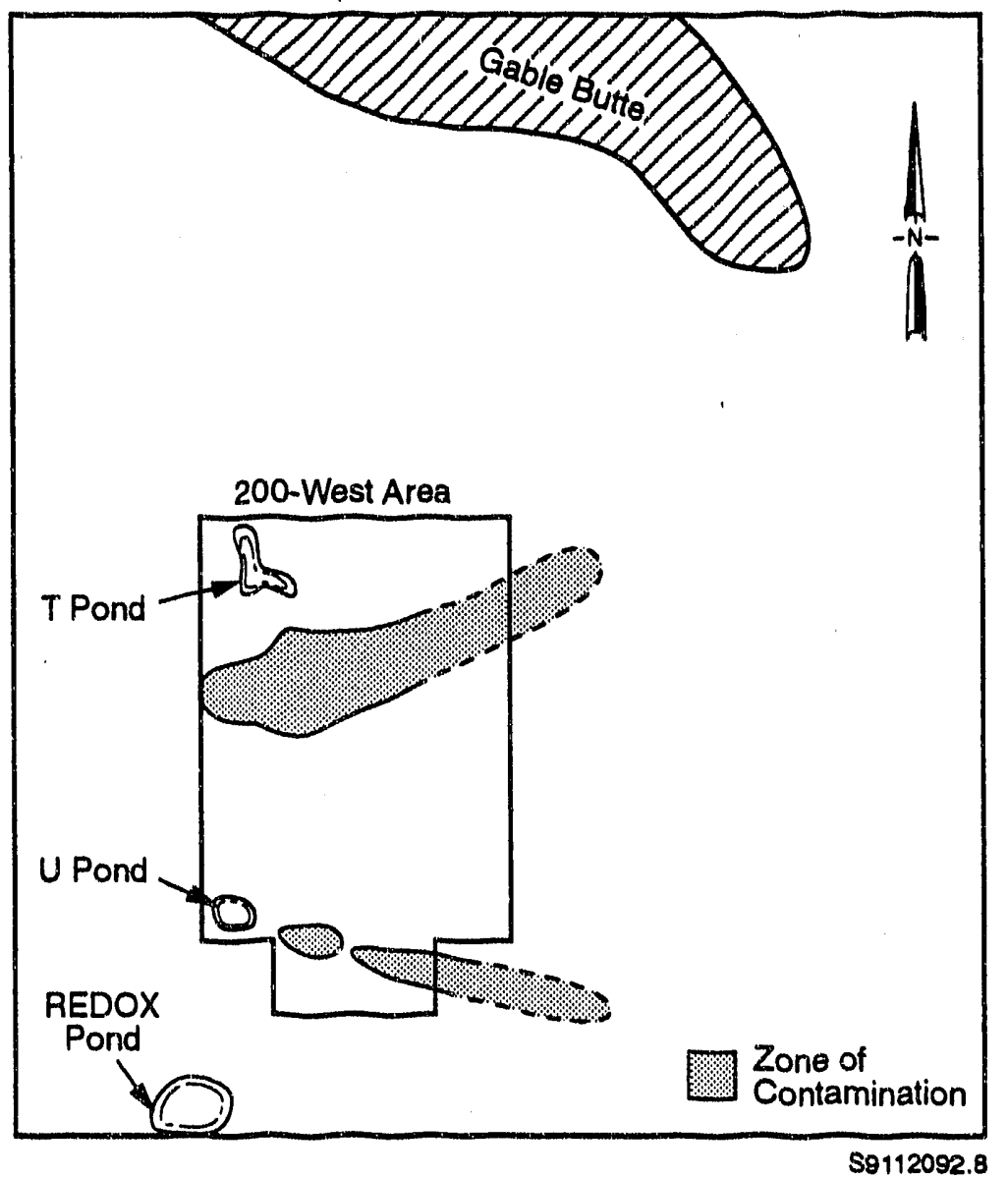

FIGURE 6.6. Approximate Extent of Known Ground-Water Contamination from ihe 200-West Area During April 1956 (after Earth Sciences Personnel 1956b)

significantly from the previous reporting period. The report did not indicate the radionuclide used to define the extent of contamination.

Brown (1957b) described westward movement of ground water and contaminants beneath the 200-East Area disposal sites. This change in direction was attributed to the ground-water mound resulting from operation of PUREX. The extent of ground-water contamination during October, November, and December 1956 (Brown 1957b) was the same as the previous reporting period, but was stated to be based on the $1.5 \times 10^{-7} \mu \mathrm{Ci} / \mathrm{ml}(150 \mathrm{pCi} / \mathrm{L})$ concentration contour. The radionuclide used to delineate the extent of contamination was not specified, but presumably was ruthenium-106 represented as gross beta. The 


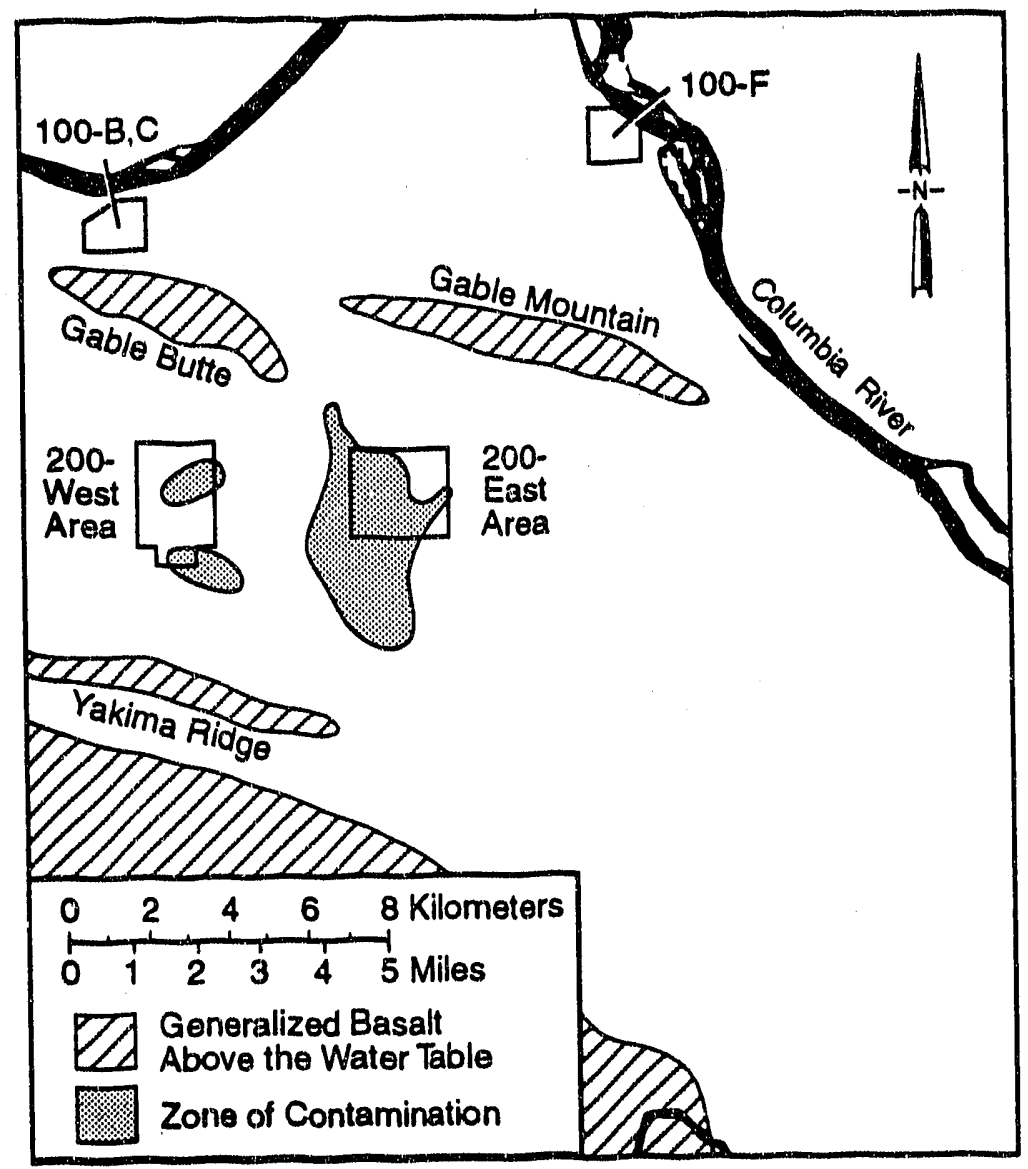

S9112092.4

FIGURE 6.7. Approximate Extent of Known Ground-Water Contamination from the 200-East and 200-West Areas During July, August, and September 1956 (after Brown 1957a)

approximate extent of ground-water contamination beneath the 200-West Area is illustrated in a like manner; no significant change from the previous quarter was noted for contamination in the 200-West Area.

Brown (1957c) reported that ground-water contamination beneath the 200 -East Area, defined by the $1.5 \times 10^{-7} \mu \mathrm{Ci} / \mathrm{ml}(150 \mathrm{pCi} / \mathrm{L})$ concentration contour (Figure 6.8), continued to move to the northwest and southeast in response to the hydraulic gradient resulting from operation of PUREX. No significant changes in the extent and distribution of contamination in ground water beneath the 200-West Area were reported during the January, February, and March 1957 reporting period. 


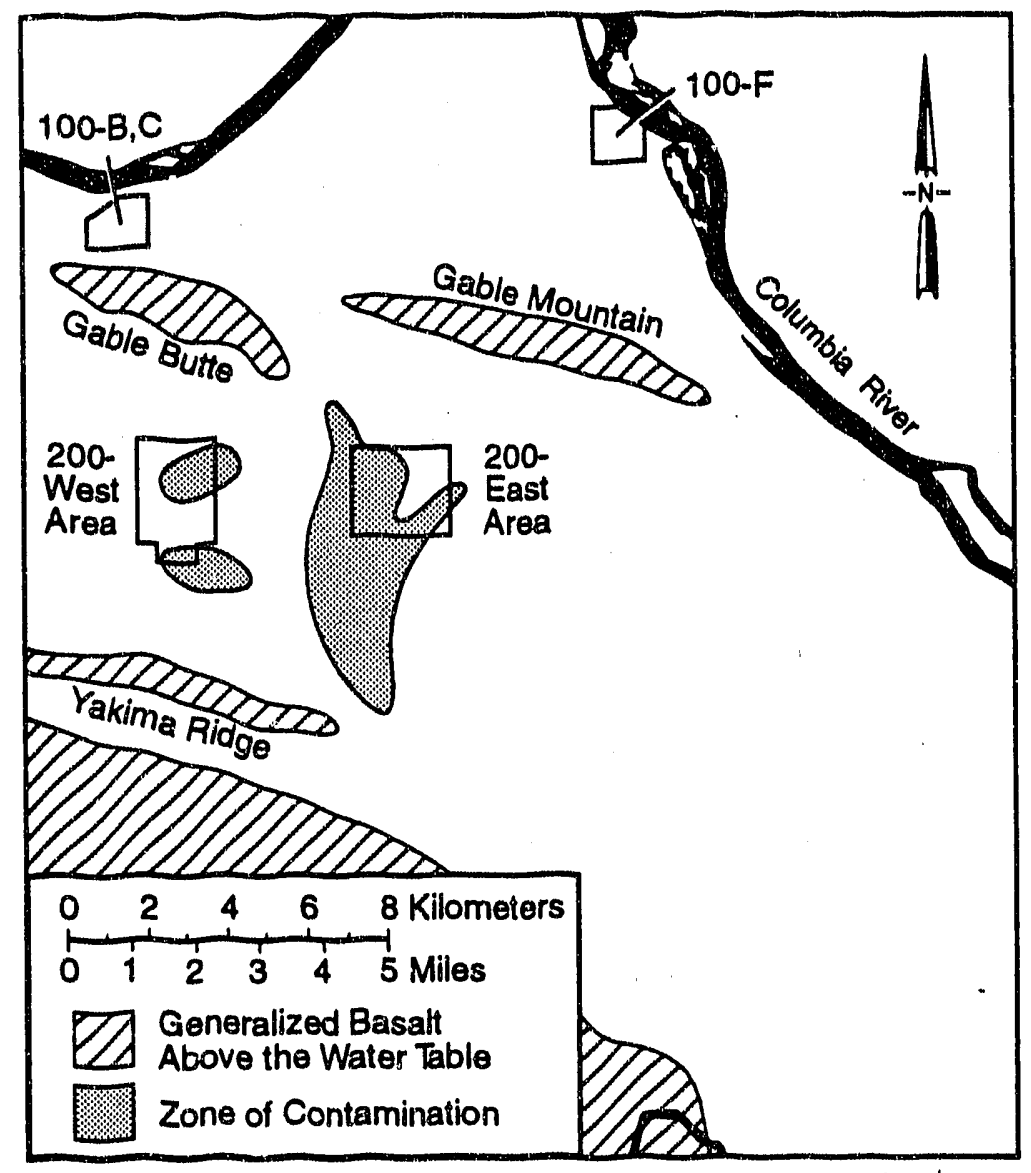

S9112092.3

FIGURE 6.8. Approximate Extent of Known Ground-Water Contamination from the 200-East and 200-West Areas During January, February, and March 1957 (after Brown 1957c)

Brown (1957d) reported that radioactive contamination beneath the 200-East Area, defined by the $1.5 \times 10^{-7} \mu \mathrm{Ci} / \mathrm{ml}(150 \mathrm{pCi} / \mathrm{L})$ gross beta concentration contour, continued to move westward and spread to the north and south during Apri1, May, and June 1957 (Figure 6.9). Wastes discharged to the ground from PUREX operations were interpreted to form a second plume in the southeast corner of the 200-East Area. In the 200-West Area, contaminants discharged to the 216-S-1 and S-2 cribs reached the water table. An additional ground-water contamination plume is shown emanating from the 216-WR cribs (Figure 6.10). The area of ground-water contamination from T-Plant 


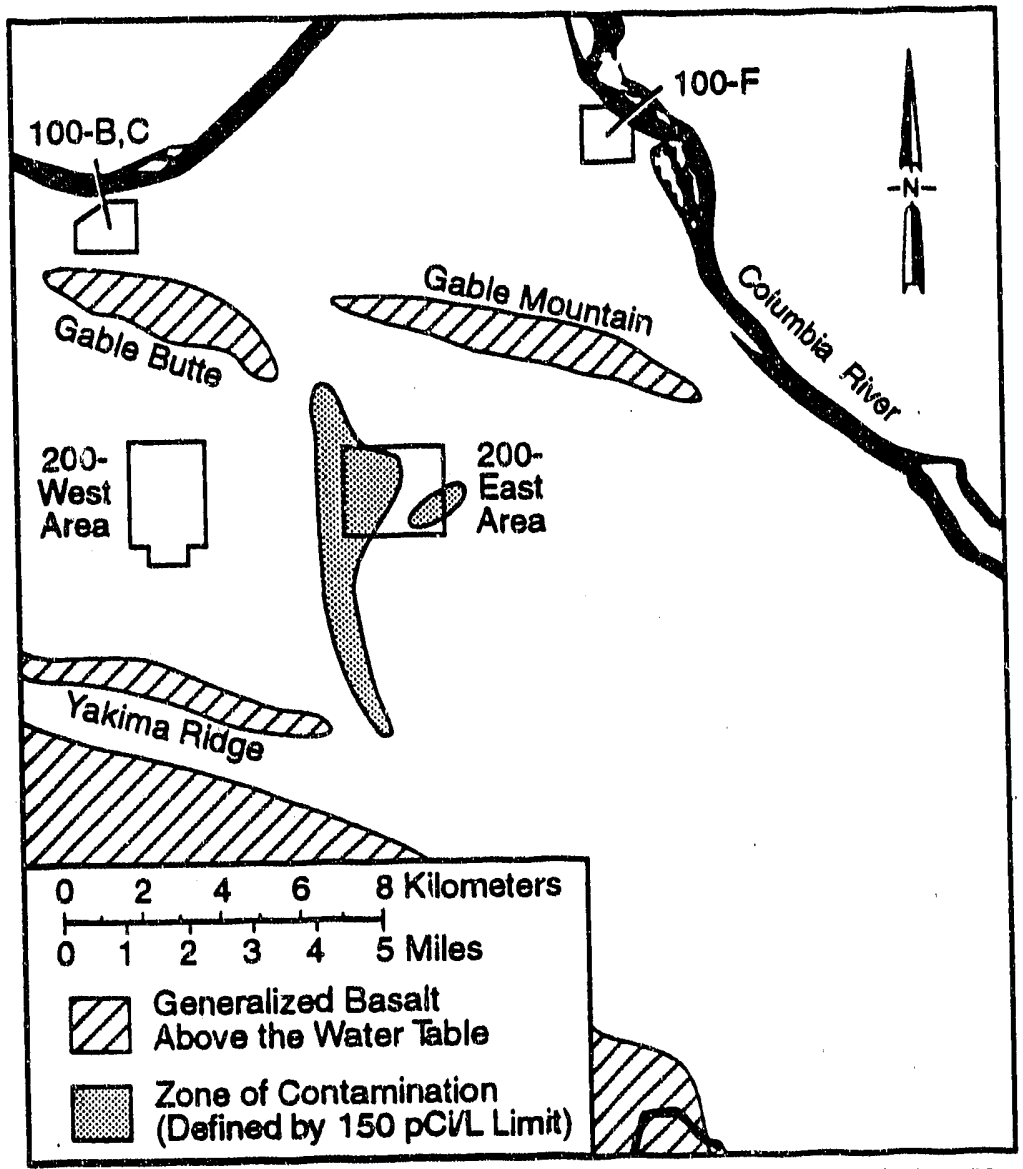

$\$ 9112092.2$

EIGURE 6.9. Approximate Extent of Known Ground-Water Contamination from the 200-East Area During Apri1, May, and June 1957 (after Brown 1957d)

operations in the northern portion of the 200-West Area was interpreted to show no change from the previous reporting period.

Brown (1957e) reported that the extent of ground-water contamination indicated by the $1.5 \times 10^{-7} \mu \mathrm{Ci} / \mathrm{ml}(150 \mathrm{pCi} / \mathrm{L})$ contour of gross beta concentrations did not change significantly during the July, August, and September 1957 reporting period. The addition of another well resulted in a larger area of contamination from the 216-WR cribs and changed the interpretation of the monitoring results for the 200-West Area.

Bierschenk (1958a) illustrated the ground-water contamination plumes beneath the 200-East and 200-West Areas for October, November, and December 


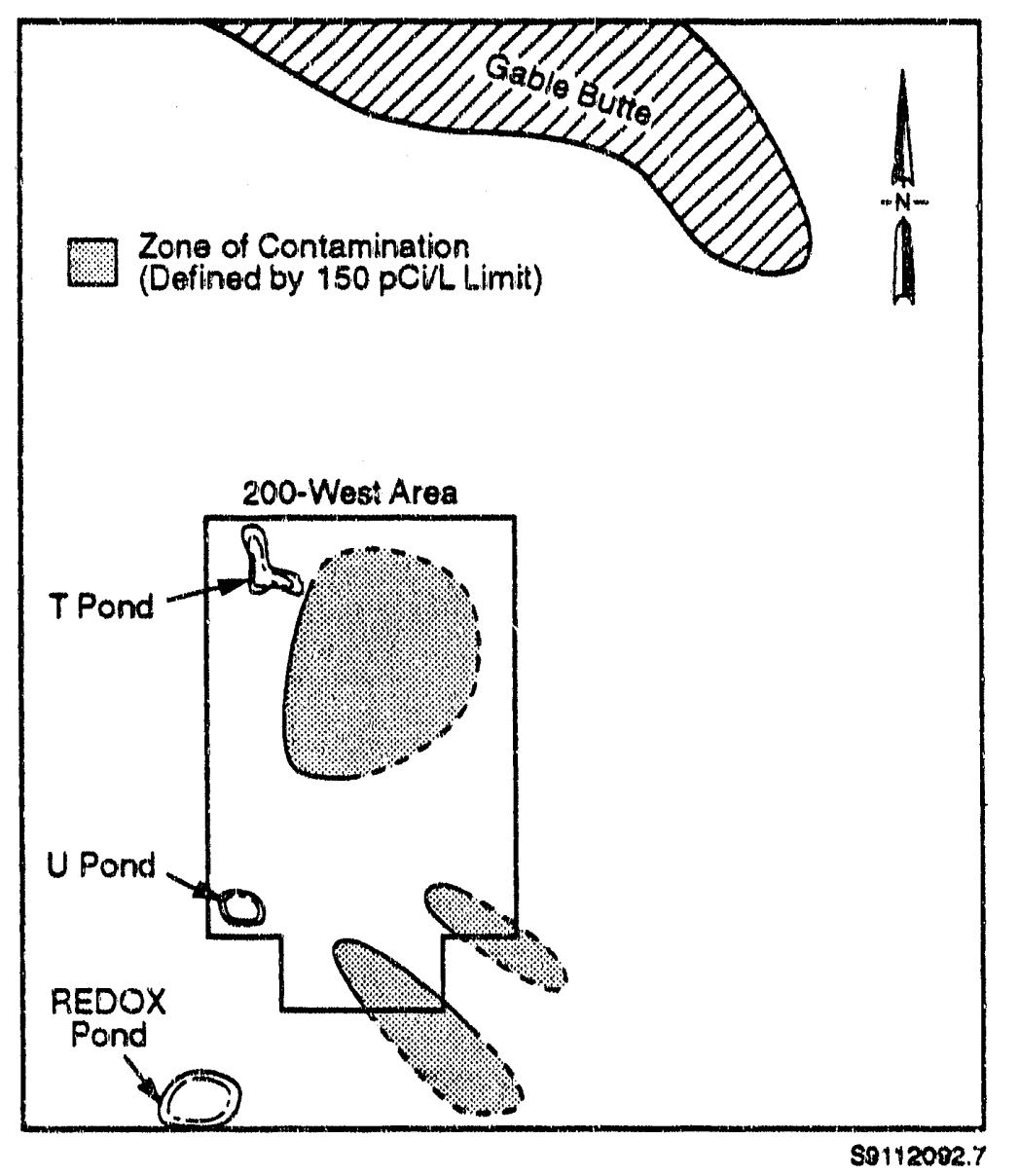

EIGURE 6.10. Approximate Extent of Known Ground-Water Contamination from the 200-West Area During Apri1, May, and June 1957 (after Brown 1957d)

1957 in a single map (Figure 6.11). As noted, the extent of contamination was defined by the $1.5 \times 10^{-7} \mu \mathrm{Ci} / \mathrm{ml}(150 \mathrm{pCi} / \mathrm{L})$ contour of gross beta concentrations. In the interpretation provided by Bierschenk (1958a), the plume from thr 216-B and 216-BY cribs in the 200-East Area coalesced with the plume from the 216-WR cribs in the 200-West Area. An additional plume in the southwest corner of the 200-West Area was the result of discharges to the 215-5-5 and S- 6 cribs associated with operation of the REDOX plant.

Bierschenk (1958b) illustrated groundwater contamination plumes beneath the 200-East and 200-West. Areas for January, February, and March 1958, defined 


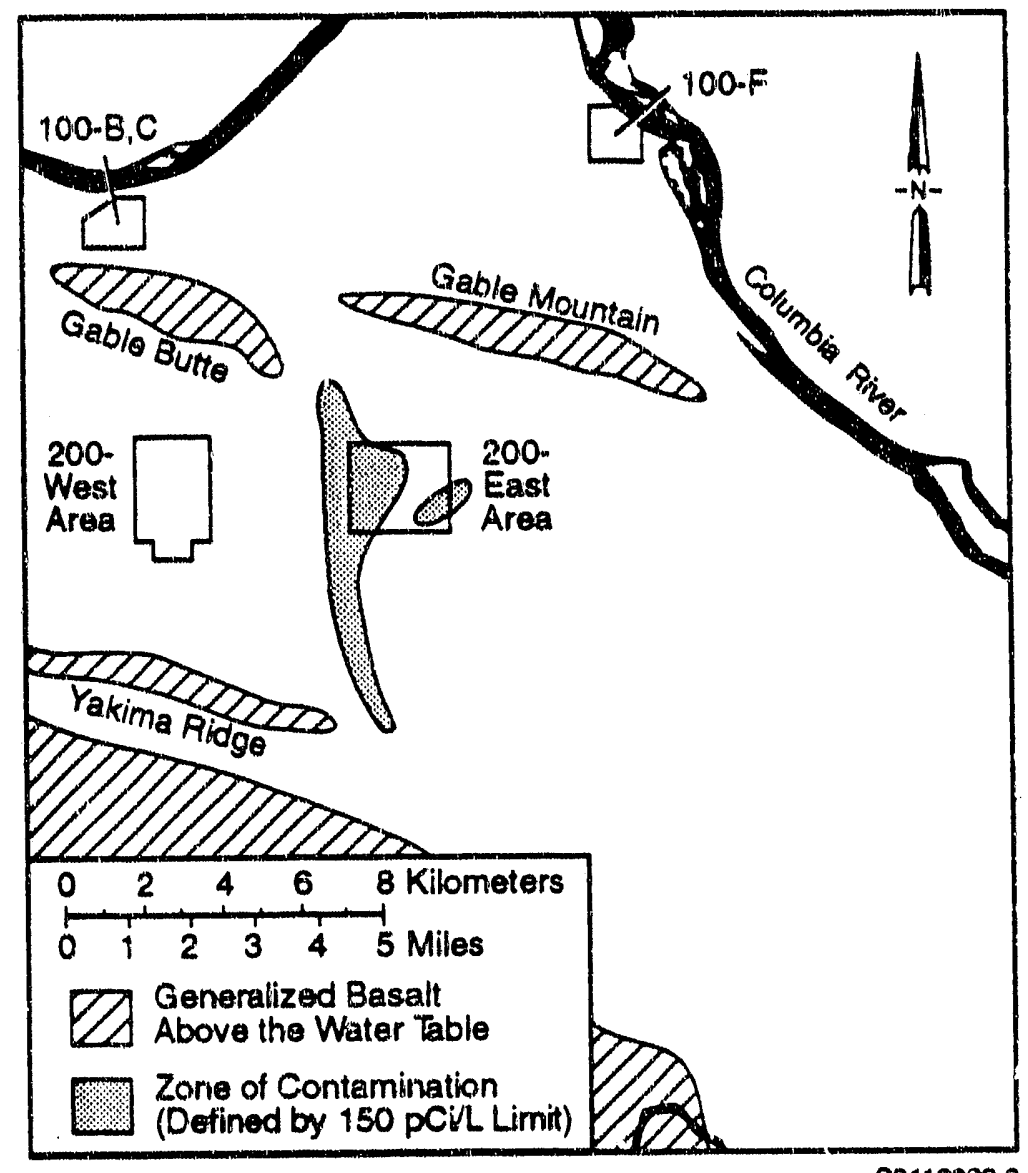

59112002.2

FIGURE 6.9. Approximate Extent of Known Ground-Water Contamination from the 200-East Area During April, May, and June 1957 (after Brown 1957d)

operations in the northern portion of the 200-West Area was interpreted to show no change from the previous reporting ceriod.

Brown (1957e) reported that the extent of ground-water contamination indicated by the $1.5 \times 10^{-7} \mu \mathrm{Ci} / \mathrm{ml}(150 \mathrm{pC} / \mathrm{A}$ ) contour of gross beta concentraitions did not change significantly during the luly, August, and September 1957 raporting period. The addition of another well resulted in a largor area of contamination from the 216-WR cribs and changed the interpretation of the monitoring results for the 200-West Area.

Bierschenk (1958a) illustrated the ground-water contamination plumes beneath the 200-East and 200-West Areas for October, November, and December 


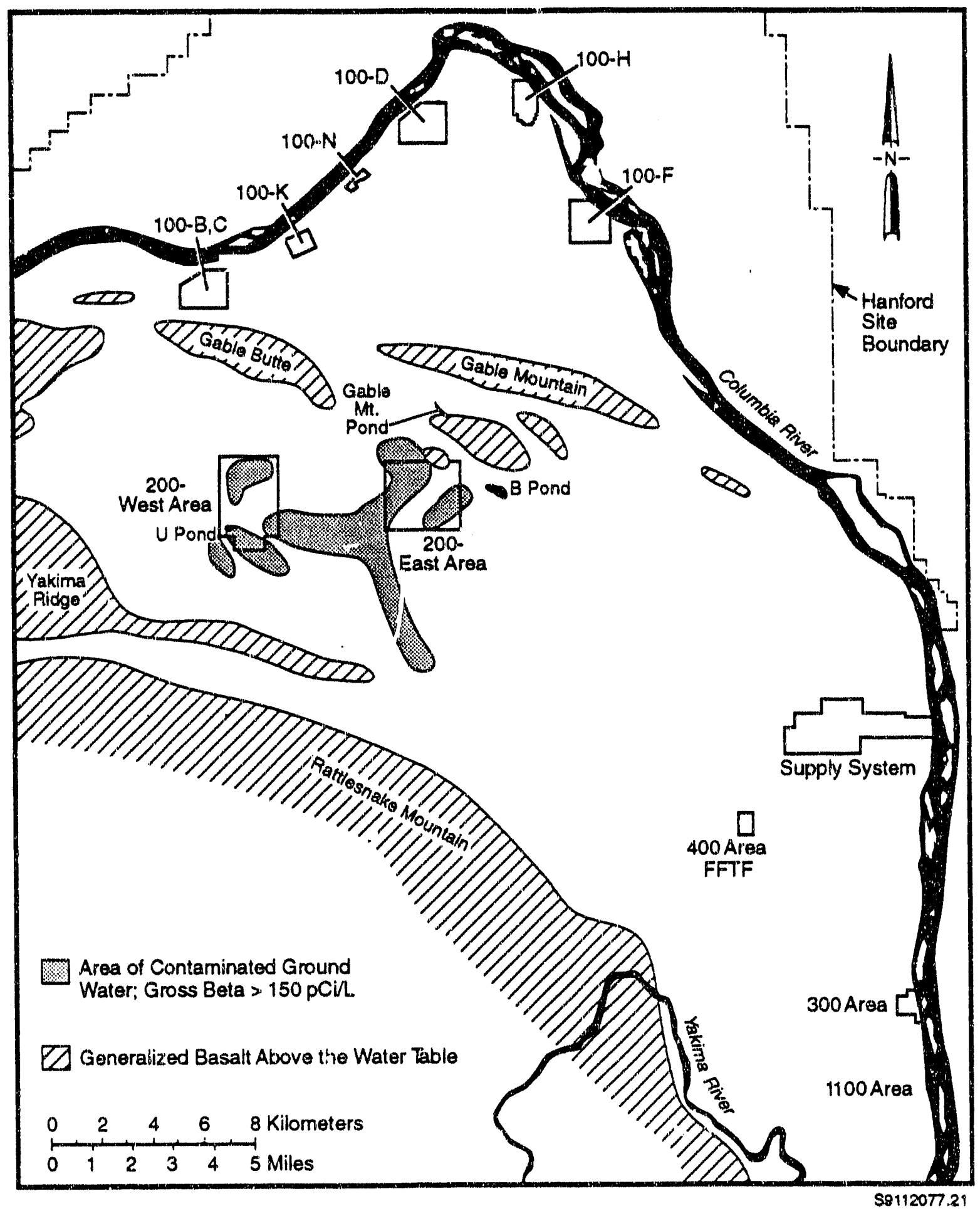

FIGURE 6.11. Approximate Extent of Known Ground-Water Contamination from the 200-East and 200-West Areas During October, November, and December 1957 (Bierschenk 1958a) 
by the $1.5 \times 10^{-7} \mu \mathrm{Ci} / \mathrm{ml}(150 \mathrm{pCi} / \mathrm{L})$ contour of gross beta concentrations (Figure 6.12). The interpretations of the plumes changed little from the previous reporting period, with the exception of closing contours to the southeast, indicating that contamination had possibly moved farther to the southeast of the 200-East Area.

Bierschenk (1958c, 1958d) reported that there were no significant changes in the concentrations or inierpretation of ground-water contamination during the April through September 1958 reporting period. As in the previous reporting period, intermittent gross beta concentrations were detected in wells monitoring the 216-BC cribs slightly south of the 200-East Area. The interpreted distributions of contamination in ground water beneath the 200-West Area were unchanged from the previous reporting period, other than the fact that the plume in the southwest corner of the 200-West Area from the 215-S-5 and S-6 cribs was not shown.

Bierschenk (1959a) provided, for the first time, contours of different levels of gross beta concentrations, starting with $1.5 \times 10^{-7}{ }_{\mu} \mathrm{Ci} / \mathrm{ml}$ $(150 \mathrm{pCi} / \mathrm{L})$ for the period of October, November, and December 1958. Previous maps had shown only an extent of contamination. Three different gross beta concentration contours are shown (Figure 6.13), with a maximum observed concentration of $1.2 \times 10^{-2} \mu \mathrm{Ci} / \mathrm{ml}\left(1.2 \times 10^{7} \mathrm{pCi} / \mathrm{L}\right)$. Bierschenk (1959a) indicated that most of the gross beta colltamination was attributed to ruthenium-106. The gross beta contaminant plumes, which are different in extent from those previously repiorted, are superimposed on a water-table map. The area shown, however, is restricted to the general 200-East and 20c-West Areas. The contaminant plume from the $215-B$ and $B Y$ cribs in the northern portion of the 200.-East Area was interpreted as having receded to the point where it was no longer connected with the plume from the 216-WR cribs in the 200-West Area.

The plume associated with discharge of wastes from PUREX to the 216-A cribs in the eastern portion of the 200-East Area was interpreted to show two separate zones of higher gross beta concentrations (Biershenk 1959a). Groundwater wells monitoring the 216-BC cribs south of the 200-East Area continued to show intermittent gross beta concentrations. No significant changes were 


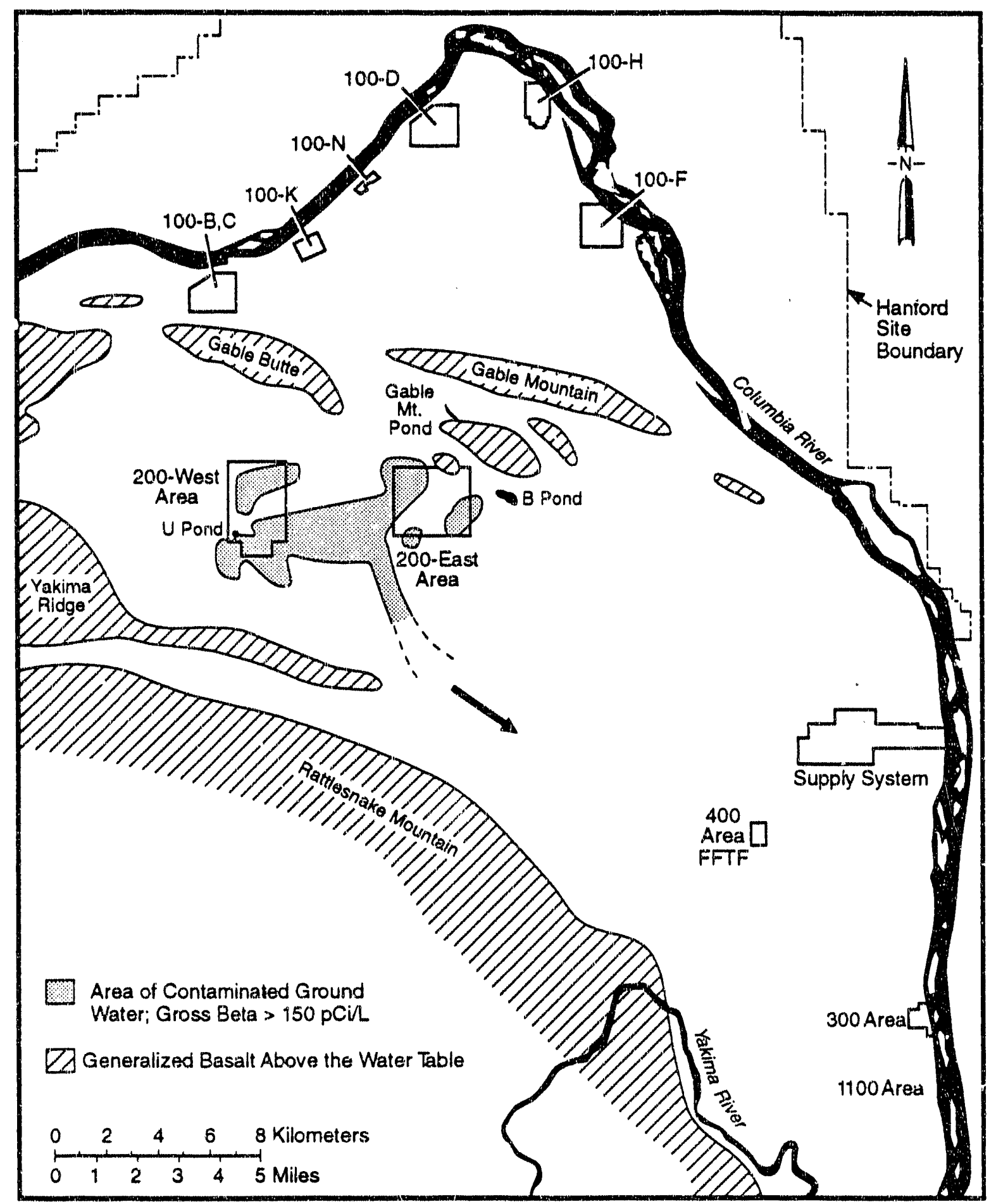

S9112077.23

FIGURE 6.12. Approximate Extent of Known Ground-Water Contamination from the 200-East and 200-West Areas During January, February, and March 1958 (after Bierschenk 1958b) 


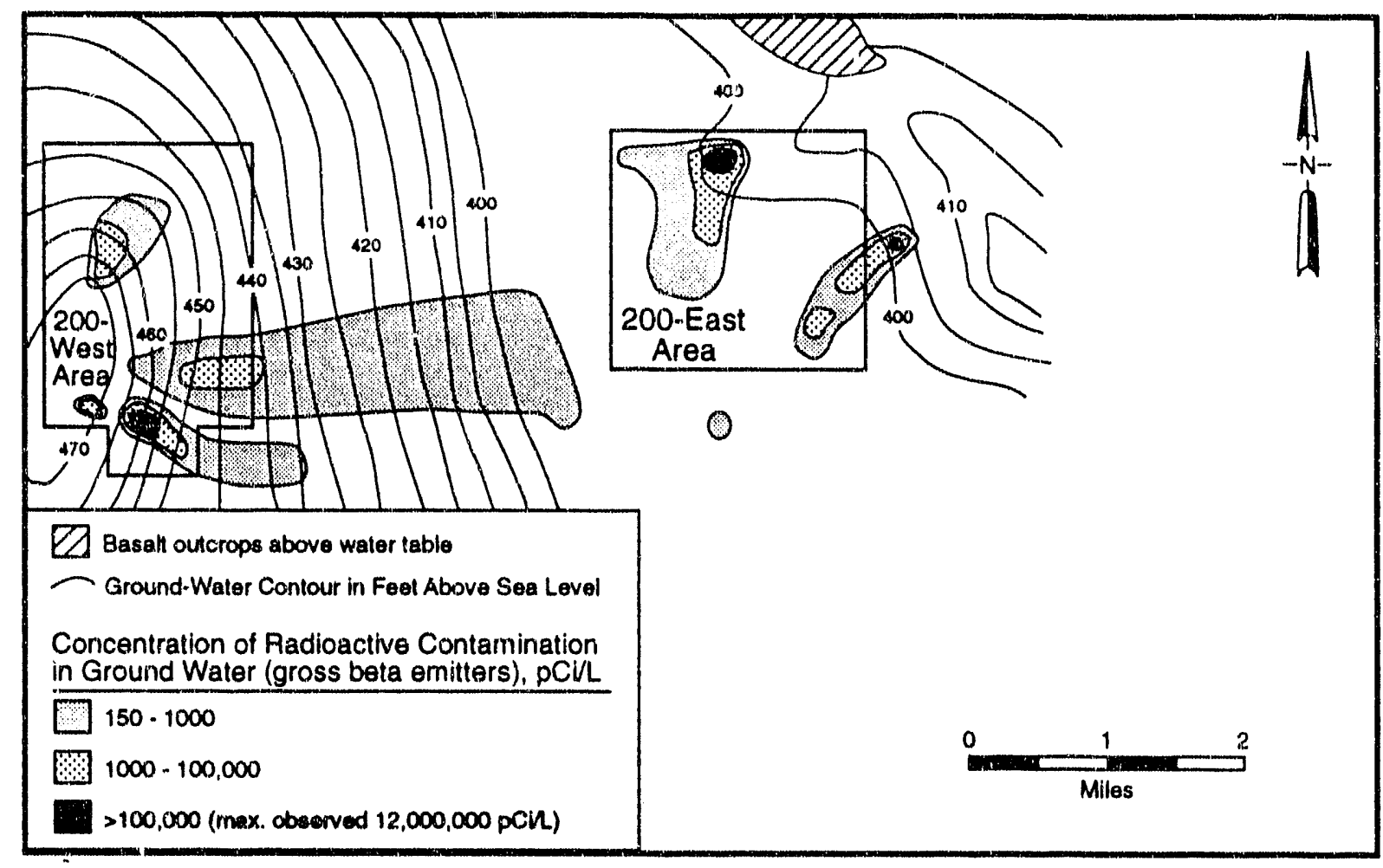

So112077.17

FIGURE 6.13. Approximate Extent of Known Ground-Water Contamination from the 200-East and 200-West Areas During October, November, and December 1958 (after Bierschenk 1959a)

noted in the 200-West Area, other than the contaminant plume from the 216-WR cribs was no Tonger connected with contamination from the 216-B and BY cribs in the 200-East Area.

The interpreted distribution of gross beta contamination in ground water beneath the 200-East and 200-West Areas renained essentially unchanged from January through June 1959. However, Bierschenk (1959d) indicated that gross beta contamination was detected in three wells, 699-34-39A, 699-31-30, and 699-24-33, approximately 5 miles southeast of the 200-East Area. These wells are outside the area shown on the map; there were no other wells between them and thie 200-East Area.

An area of contaminated ground water southeast of the 200 -East Area is shown in Figure 6.14 from Haney (1959). However, the plume was not connected 


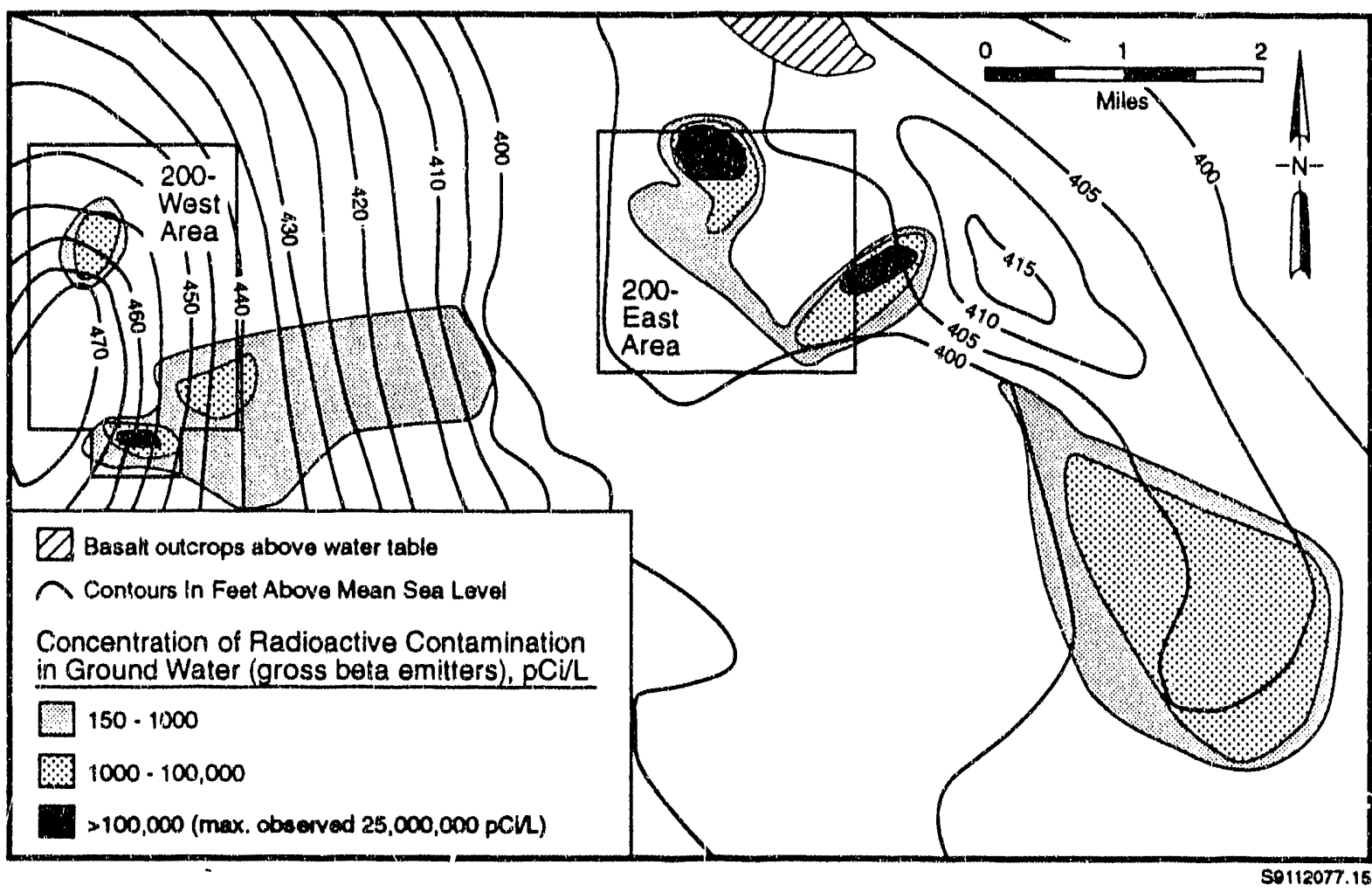

FIGURE 6.14. Distribution of Known Ground-Water Contamination Based on Gross Beta Measurements for September 1959 (after Haney 1959)

with any of those interpreted to exist within the 200-East Area because it did not have an identified source; two probable sources were identified as the 216-BY cribs or the 216-A cribs. The interpretation of this plume was based on gross beta concentrations for two wells, 699-31-30 and 699-34-39A, and was complicated by information from the hand-drawn water-table map which indicated that these wells are upgradient of the probable sources. At the time, Haney (1959) attributed the conflicting monitoring and hydrologic information to water-level variations in response to waste discharges in both the 200-East and 200-West Areas.

The interpreted distribution of gross beta contamination in the aquifer presented in Haney (1960a) for October, November, and December 1959 (Figure 6.15) was dramatically different from those included in previous quarterly reports. Haney (1960a) interpreted the gross beta contamination in samples from wells 699-34-39A, 699-31-31, and 699-24-33 as being connected with the 


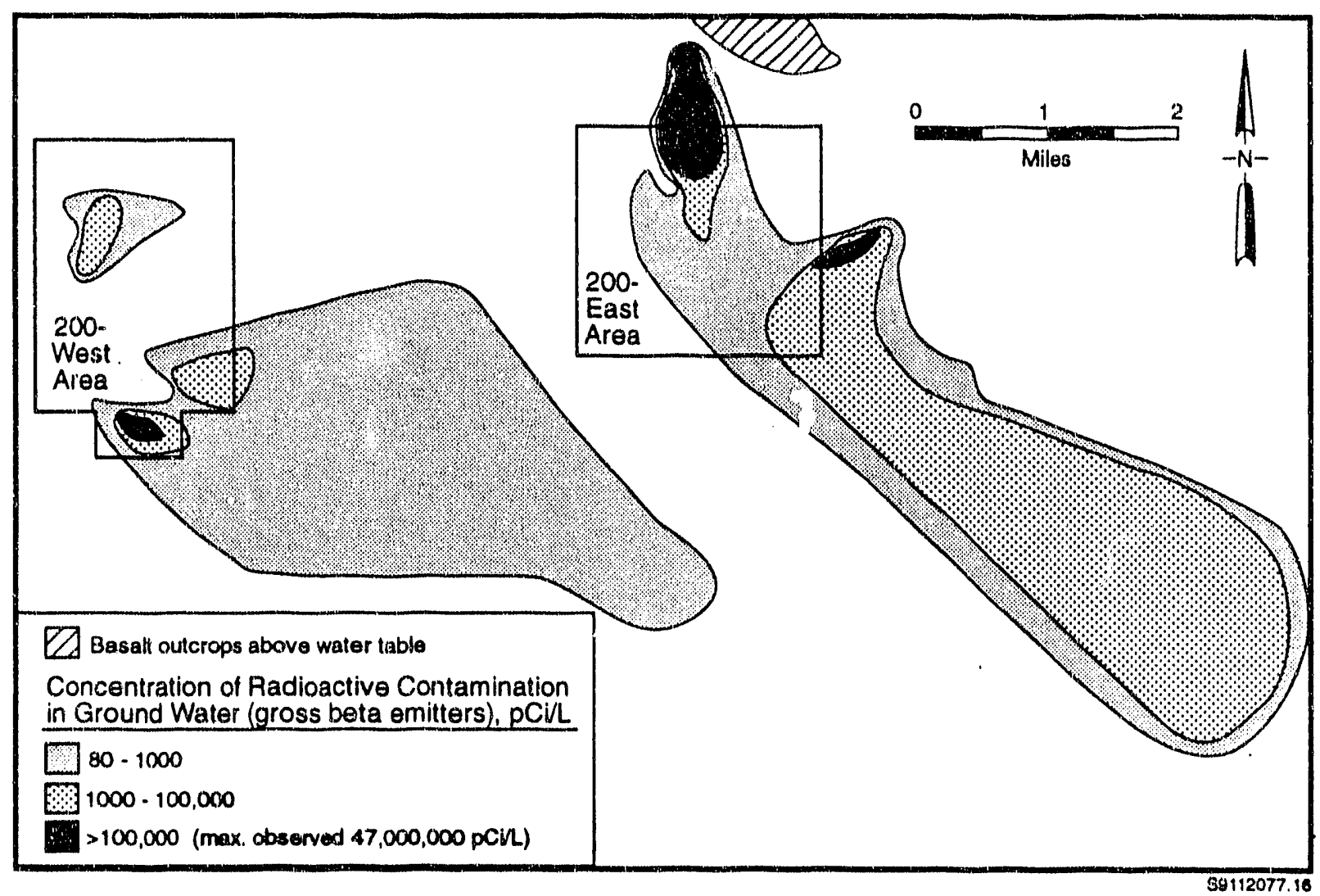

FIGURE 6.15. Distribution of Known Ground-Water Contamination Based on Gross Beta Measurements for October, November, and December 1959 (after Haney 1960a)

plumes beneath the 216-A (PUREX) cribs, thus identifying these cribs as the source. Wells southeast of the 200-East Area were resurveyed for control elevations at the ground surface. These control elevations were used for depthto-water measurements to establish elevations for contouring the water-table maps. The resurvey showed that surface casing elevations for wells 699-30-31 and 699-24-33 were in error by approximately 7 feet. Once the error was corrected, wells 699-34-39A, 699-30-31, and 699-24-33 were interpreted as being approximately downgradient of the $216-A$ cribs. In addition, the interpretation of the plume from the 216-BY cribs changed to reflect migration of greater than $\left.1 \times 10^{-4} \mu \mathrm{Ci} / \mathrm{m}\right\}(100,000 \mathrm{pCi} / \mathrm{L})$ concentrations of gross beta to the north and to reflect connection of the lower concentrations with the plume from the 216-A cribs. Connecting the lower concentrations in the 216-BY gross 
beta plume with those from the 216-A plume probably reflects a lower detection limit for gross beta concentrations of $8 \times 10^{-8}{ }_{\mu} \mathrm{Ci} / \mathrm{ml}(80 \mathrm{pCi} / \mathrm{L})$. The plume of contamination from the 216-WR and REDOX cribs in the southeastern corner of the 200-West Area was interpreted to have spread farther to the southeast, reflecting the lower detection limit for gross beta concentrations.

The interpreted distribution of gross beta contamination in the 200-East and 200-West Areas from January through December 1960 is essentially unchanged from the previous reporting period (Haney 1960b, 1960d; Haney 1961a, 1961b). The exceptions to this observation were in the plume southeast of the 200-East Area and east of the 200-West Area. Low gross beta concentrations showed up during the January through June 1961 reporting period in wells 699-26-15 and 699-20-20. These wells are located 2.5 miles east and southeast of well 699-24-33, the southernmost well with gross beta concentrations during the previous reporting period. Haney (1961b) observed that, based on first arrival of radionuclides at we 11 699-24-23 and subsequent arrival at the downgradient wells (699-26-15 and 699-20-20), movement over the 2.5 miles occurred in approximately 2.5 years.

Haney (1961b) marked a change from quarterly to semiannual reporting of the Chemical Effluents Technology Operations activities. For the first time in a quarterly report (Haney 1961b), the average gross beta measurements for each well sampled at the Hanford Site were included in an appendix table.

The distribution of gross beta concentrations for July through December 1962 defined by the $8 \times 10^{-8} \mu \mathrm{Ci} / \mathrm{ml}(80 \mathrm{pCi} / \mathrm{L})$ detection limit (Figure 6.16) was different from the previous reporting period (Brown 1963). The gross beta plume that extends southeast from the 200-East Area was mapped as having extended nearly to the river. Brown (1963) noted only minor changes in the distribution of gross beta concentrations in the 200-West Area, although a larger area of contamination to the west is shown.

The distribution of gross beta concentrations for January through June 1963 (Figure 6.17) in Haney (1963) was different from that in the previous reporting period in that the plume was interpreted to have retreated from the river. However, intermittent concentrations of gross beta emitters were 


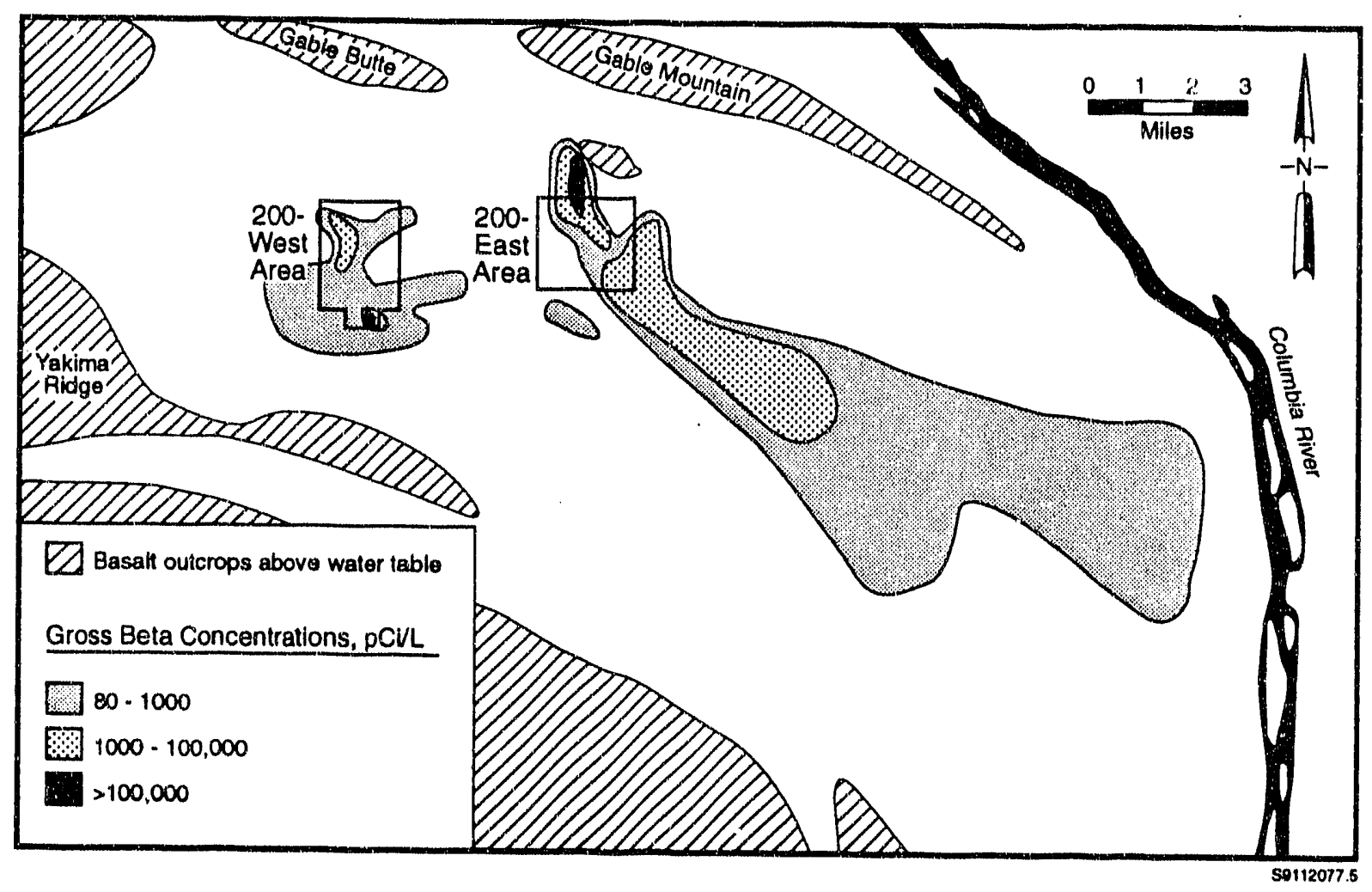

EIGURE 6.16. Oistribution of Average Gross Beta Concentrations in the Unconfined Aquifer During July Through December 1962 (after Brown 1963)

observed in wells near the river and were mapped as isolated zones of gross beta contamination. The reduction in the extent of gross beta contamination was attributed to reductions in the quantity of radioactive waste discharged to the ground from the REDOX plant and to decay of low concentrations of ruthenium-106 and rhodium-106.

The distribution of gross beta concentrations reported by Brown and Haney (1964) was interpreted to indicate that the gross beta plume had reached the Columbia River, based on intermittent detectable concentrations (Figure 6.18). Brown and Haney (1964) based estimates of travel time on "...the appearance time of gross beta-emitters (ruthenium-106 and rhodium-106) and tritium in monitoring wells located at various distances from liquid waste disposal sites." They estimated an average travel time of 7 to 8 years for ruthenium106 to move from the PUREX plant southeast to the Columbia River. They also 


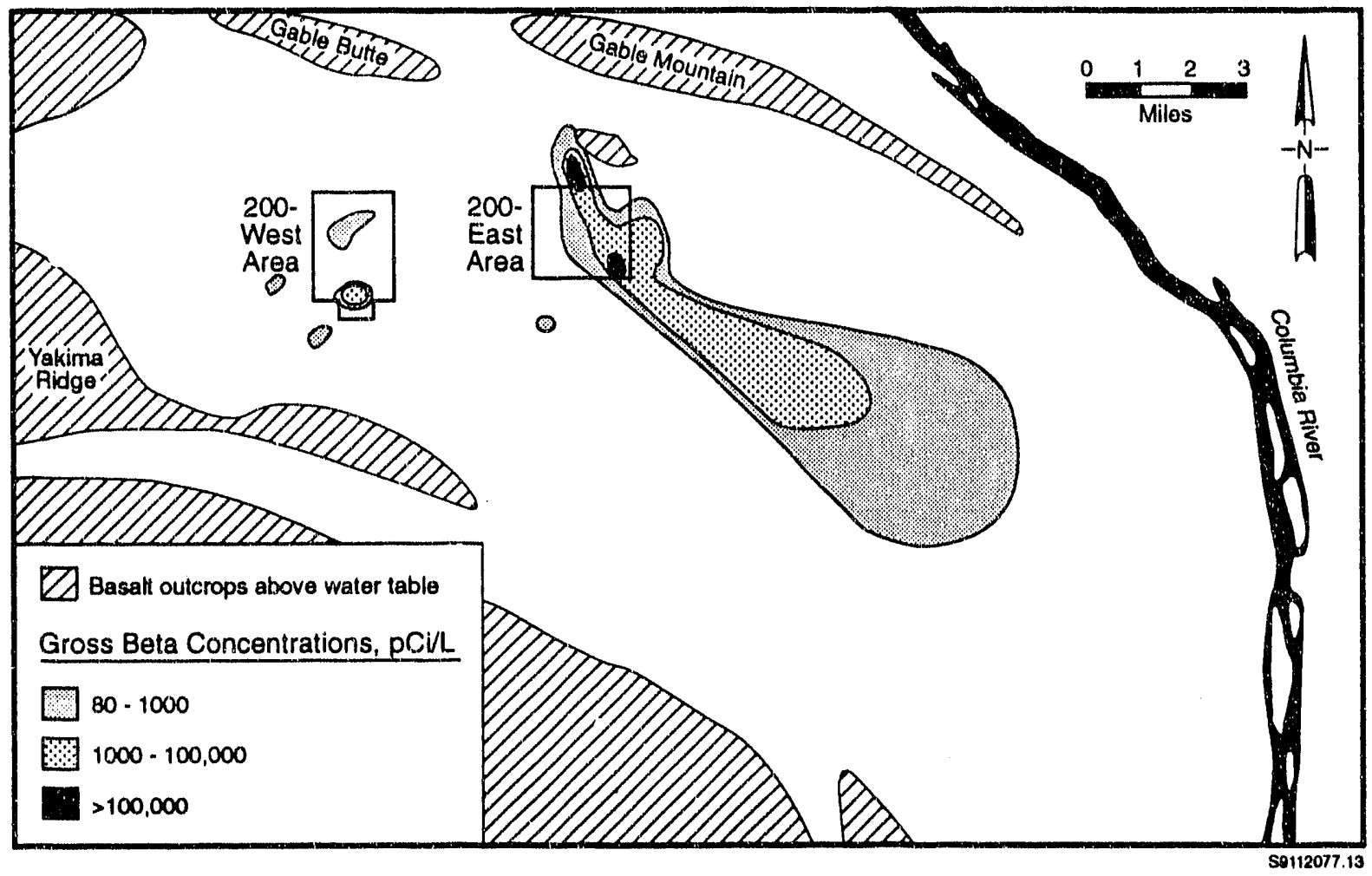

FIGURE 6.17. Distribution of Average Gross Beta Concentrations in the Unconfined Aquifer During January Through June 1963 (after Haney 1963)

estimated a travel time of 20 years to the river for "radioconicaminants" discharged to the ground from the REDOX plant in the 200-West Area.

The distribution of average gross beta concentrations for January through December 1964 (Figure 6.19) reported in Brown (1964) was different from the previous reporting period in several areas. The gross beta plume was mapped as having reached the river. A zone of detectable concentrations (10 to $100 \mathrm{pC} i / L)$ is shown adjacent to the river, where ground water and Columbia River water mix during periods of high river stage.

The interpreted distribution of average gross beta concentrations for January through June 1965 reported in Brown (1965) was essentially the same as that during the previous reporting period. Samples collected from wells in the large gross beta plume southeast of the 200-East Area were analyzed to determine the isotopes contributing to the gross beta concentrations. Brown 


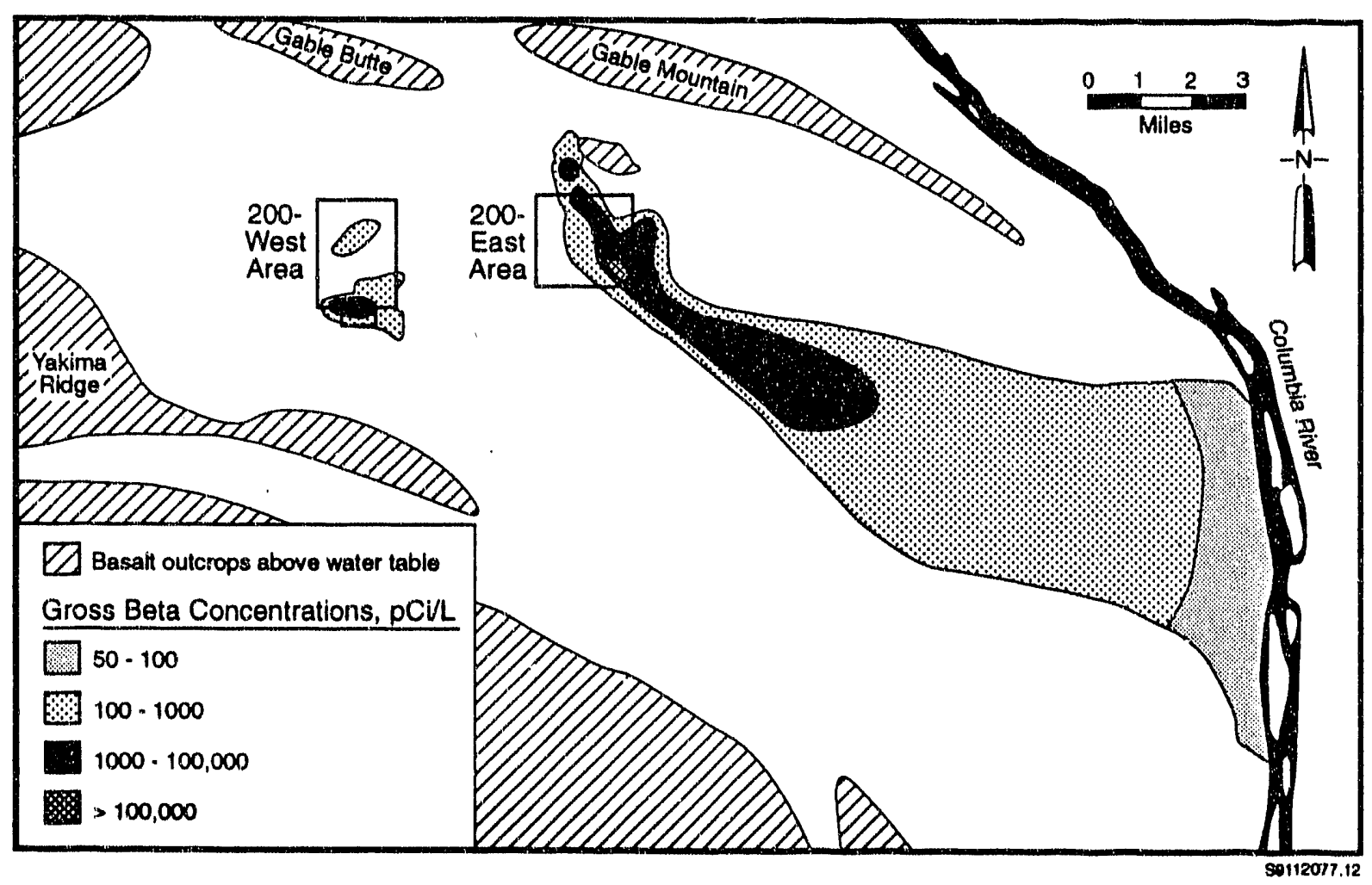

FIGURE 6.18. Distribution of Average Gross Beta Concentrations in the Unconfined Aquifer During July. Through December 1963 (after Brown and Haney 1964)

(1965) interpreted the results to indicate that essentially all of the gross beta activity was attributable to ruthenium-106/rhodium-106 and tritium (1ater researchers stated that none of the gross beta was tritium). Brown (1965) reported that analyses of ground-water samples from wells near the Columbia River showed detectable concentrations of both ruthenium-106 and chromium-51. This finding was interpreted as an indication that ground water and river water were mixed because ruthenium-106 is associated with ground-water contamination and chromium-51 from reactor operations was present in the Columbia River (Hall 1991).

The distribution of average gross beta concentrations in the unconfined aquifer from July through December 1965 (Figure 6.20) reported by Eliason (1966a) changed considerably from the previous reporting period. This 


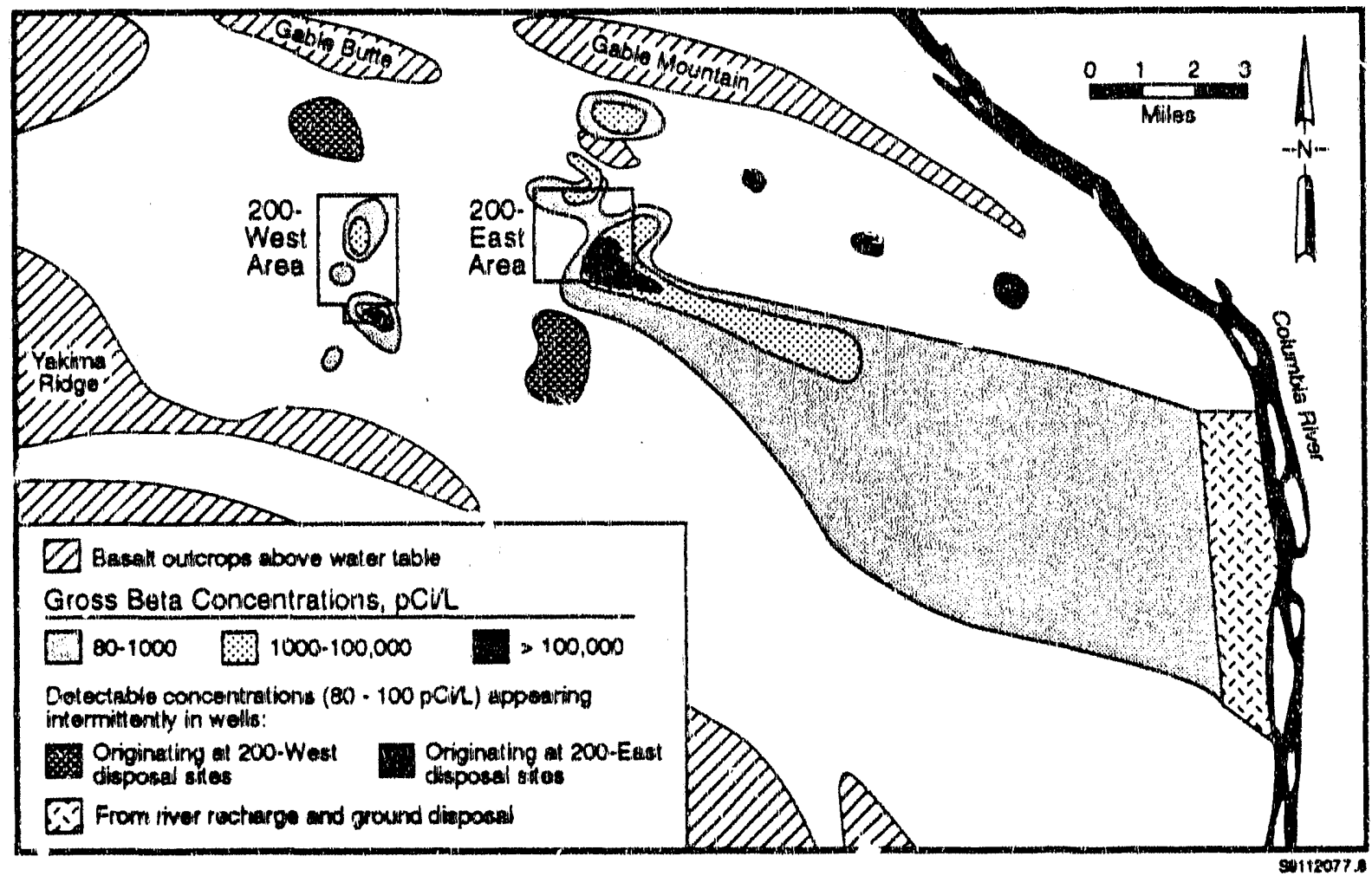

EIGURE 6.19. Oistribution of Average Gross Beta Concentrations in the Unconfined Aquifer During January Through December 1964 (after Brown 1964)

interpretation was based on the same reporting levels (contours) and detection $1 \mathrm{imit}[0.08 \mathrm{pCl} / \mathrm{ml}(80 \mathrm{pCl} / \mathrm{h})]$ as in previous reporting periods. However, Eliason (1966a) interpreted the extent of contamination to be larger, based on detection of gross beta in several additional wells.

Eliason (1966b) provided a summary of gross beta measurements from the unconfined aquifer from January through June 1966. The interpreted distribution of average gross beta contamination in the aquifer was slightly different from the previous reporiting perlod. Eliasun (1966b) included a discussion of travel-time predictions for beta. emitters from the 216-A-10 crib downgradient of well 699-34-39A. In late 19⿺2, an increase of beta activity discharged to the 216-A-10 crib for a 2-month period was observed. A maximum activity in 


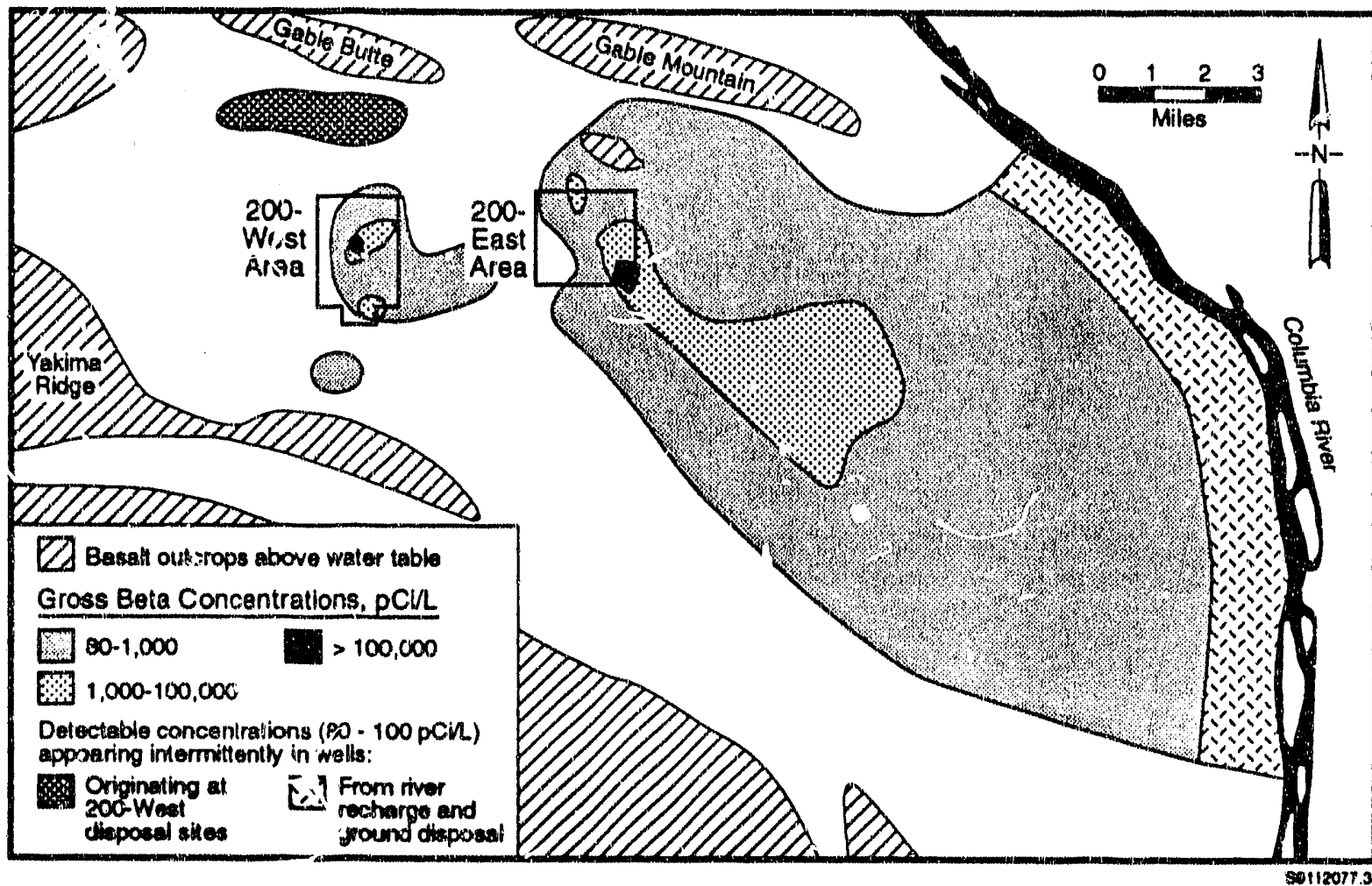

EIGURE 6.20. Distribution of Average Gross Beta Concentrations in the Unconfined Aquifer During July Through December 1965 (after Elidson 1966a)

well 699-34-39A was observed in January 1965 (Figure 6.21), which confirms a 2-year prediction by Brown and Haney (1964). The travel time to this point. was 26 months (just over 2 years).

The interpreted distribution of gross beta contamination in the unconfined aquifer changed only minor amounts from July 1966 through December 1974 (Eliason 1967b; Kipp 1972; Kipp 1973a, 1973b; Raymond et al. 1976). Kipp (1972) cautioned that concentration contours presented in the report should not be interpreted as indicating that no radioactivity was present in the ground water beyond the outermost boundary of the interpreted plume. Some radionuclide concentrations exist outside this boundary and may even have reached the Columbia River, but were not detestable by the measurement techniques employed at the time. 


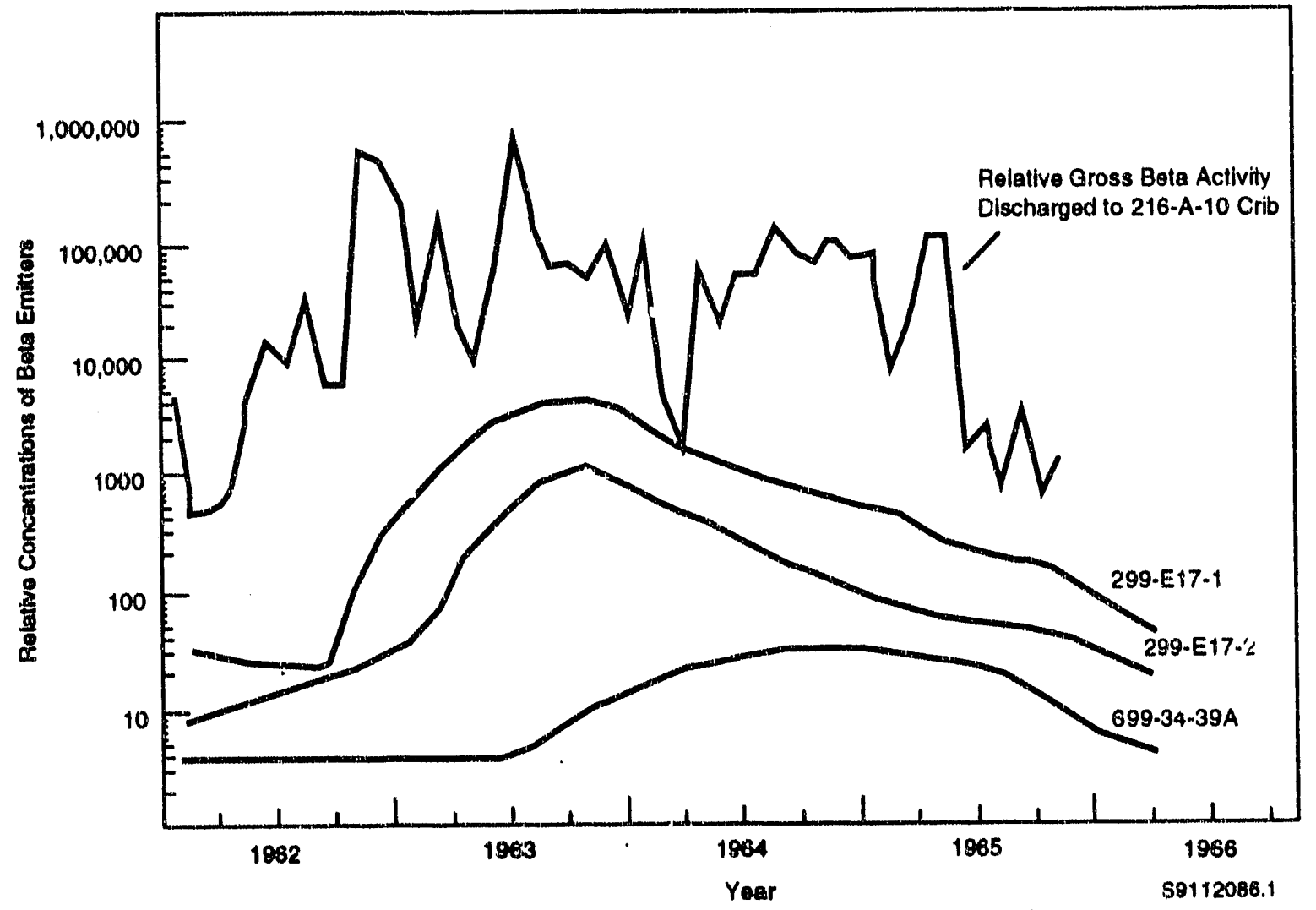

EIGURE 6.21. Response of Downgradient Monitoring Wells to Gross Bcia Emitters Discharged to the 216-A-10 Crib (after Eliason 1966b)

The distribution of gross beta contamination in the unconfined aquifer during 1974 (Figure 6.22) changed only slightly from the previous reporting period, although the plume was beginning to shrink (Raymond et a1. 1976). Previously, the $0.08 \mathrm{pCi} / \mathrm{ml}(80 \mathrm{pCi} / \mathrm{L})$ contour was used to define the extent of the gross beta plume. The plume in Figure 6.22 was defined by the $0.1 \mathrm{pCi} / \mathrm{ml}(100 \mathrm{pCi} / \mathrm{L})$ contour.

The contribution of different radionuclides to the gross beta concentrations in ground water at the Hanford Site changed from previous interpretations. Previously, ruthenium-106 was assumed to be the dominant contributor to gross beta concentrations at all locations on the Hanford Site. Raymond et al. (1976) reported that the contribution of other radionuclides to gross beta was important at different locations in the unconfined aquifer. 


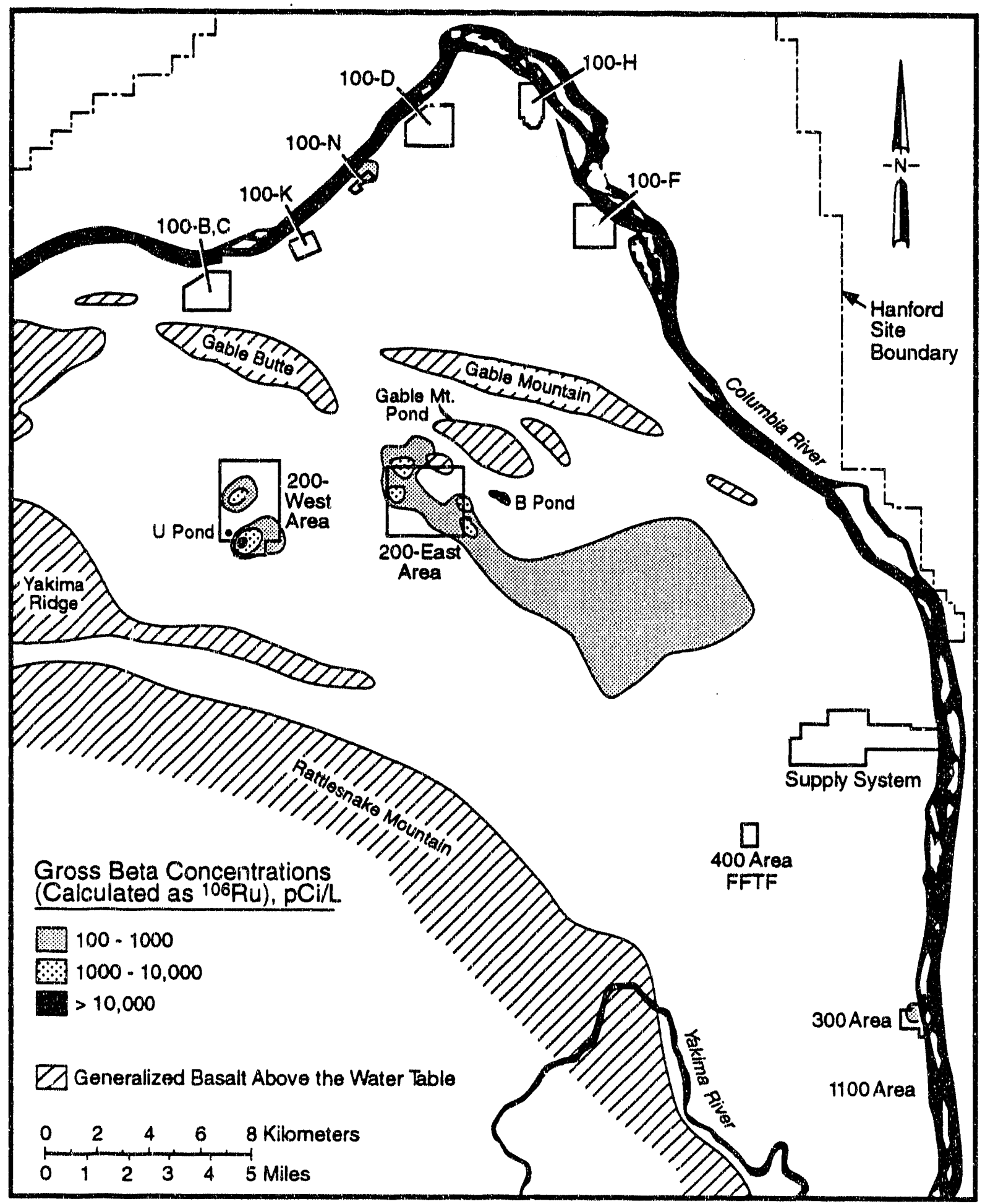

$\$ 9112077.29$

EIGURE 6.22. Distribution of Average Gross Beta Concentrations in the Unconfined Aquifer During 1974 (Raymond et a1. 1976) 
Specifically, away from the operating areas, cobalt-60 was found to be the dominant contributor to gross beta concentrations. This difference is because ruthenium-106 has a shorter half-1ife (367 days) than cobalt-60 (5.3 years), so the ruthenium-106 concentrations in the ground water were reduced more than cobalt-60 concentrations. Table 6.3 illustrates differences in the ratio of ruthenium-106 to cobalt-60 concentrations in the ground water southeast of the 200-East Area.

Myers et a1. (no date) reported that during 1975, the gross beta plume continued to decrease beci ise of radioactive decay. Myers et a1. (no date) attempted to correlate peaks in gross beta concentrations at wells 699-34-42 and 699-33-22 with source releases in the 200-East Area. However, correlation was difficult because dispersion within the flow system coalesced minor contaminant plumes from different release points and masked the true time of release from any one source.

Myers, Fix and Raymond (1977) reported that the gross beta plume continued to shrink during this reporting period. The interpretation of the plume, however, showed only minor changes compared with the previous year. Further analyses were performed on ground water using a large-volume water sampler to refine definition of the key radionuclides contributing to the gross beta concentrations. Ruthenium-106 and cobalt-60 were found to be the dominant contributors to gross beta, confirming previous analyses by Raymond et al. (1976).

Eddy and Wilbur (1980) reported that during 1979, the gross beta plume continued to recede because of radioactive decay. By 1982 , gross beta

TABLE 6.3. Ratio of Ruthenium-106 to Cobalt-60 for Selected Wells Southeast of the 200-East Area During 1974 (Raymond et al. 1976)

\begin{tabular}{cc} 
We11 Number & $\begin{array}{c}\text { Ruthenium-106/Cobalt }-60 \\
\text { Concentration Ratios }\end{array}$ \\
\hline $699-34-39 A$ & 1.12 \\
$31-31$ & 0.29 \\
$20-20$ & 0.20 \\
$26-15$ & 0.17
\end{tabular}


concentrations in the aquifer had decreased, and the plumes had receded to a point where it was no longer necessary to include the maps in the annual reports (Eddy, Prater and Rieger 1983).

\section{Tritium}

Tritium is the most mobile of the radionuclides discharged to the ground in large quantities at the Hanford Site; because it exchanges with stable hydrogen in water molecules, it moves directly with the ground water. It is currently the most extensive'y monitored radionuclide in the ground water at the site and has been used as an indicator of the maximum extent of groundwater contamination since it was determined to be present (Jaquish and Bryce 1990). The most recently published distribution of tritium in the unconfined aquifer is illustrated in Figure 6.23 .

Because of differences in geology, the pattern of migration for radionuclicies moving out of the 200-East Area differed from that of radionuclides moving out of the 200-West Area. The tritium plume to the east and southeast of the 200-East Area has a much larger distribution than the tritium plume south of the 200-West Area (Figure 6.23). In the 200-West Area, the water table is located in the middle Ringold Formation; whereas, in the 200-East Area, it is located in the more permeable Hanford formation (Jaquish and Bryce 1990). The higher permeability of the Hanford formation allows contamination to migrate a greater distance from the 200-East Area than from the 200-West Area where the ground water (and contamination) is in the middle Ringold Formation.

Tritium was not always monitored in the unconfined aquifer because, before 1959, its release was not recognized to be a result of Hanford Site chemical separations operations. Tritium is a low-energy beta emitter that was not detected with the gross beta measurement methods used during early monitoring at the Hanford Site. In 1959, tritium was reported in offsite publications as a byproduct of uranium fission (Albenesius 1959). After this discovery, waste streams discharged to the ground and the ground water beneath the 200 Areas were analyzed for tritium (Haney, Brown and Reisenauer 1962). 


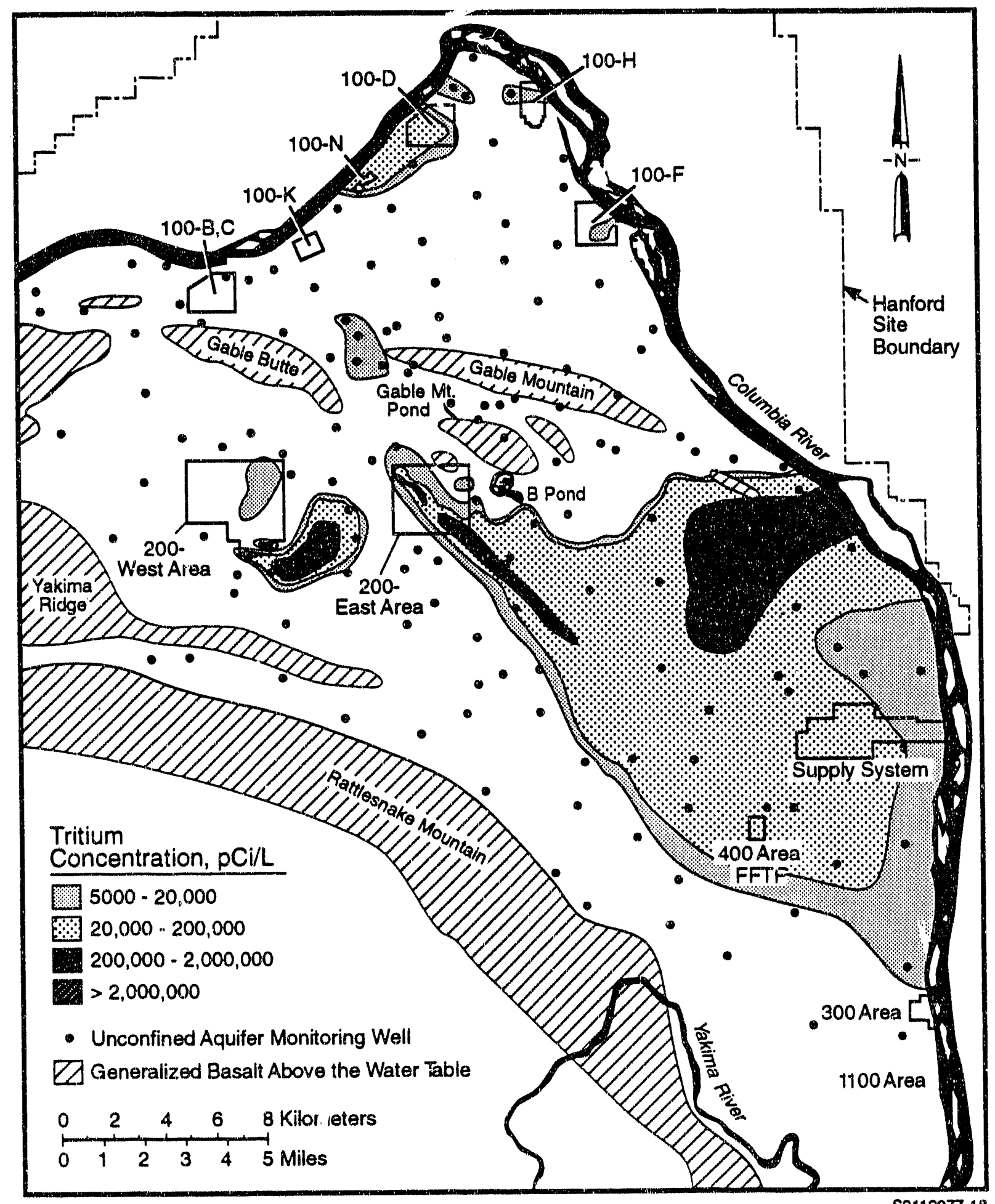

S9112077.18

FIGURE 6.23. Distribution of Average Tritium Concentrations in the Unconfined Aquifer During 1989 (after Jaquish and Bryce 1990) 
The first monitoring results for tritium in the ground water were reported in Brown (1962b). For the initial assessment of the extent of tritium in the unconfined aquifer, samples were collected from 55 monitoring wells that were already part of the routine monitoring network. The highest concentration reported from the initial sampling was $0.05 \mu \mathrm{Ci} / \mathrm{ml}$ $\left(5 \times 10^{7} \mathrm{pCi} / \mathrm{L}\right)$ in well 699-34-39A. Results of the initial sampling for other wells were summarized in an appendix in Brown (1962b).

The first map produced to illustrate the distribution of tritium contamination in the unconfined aquifer (Figure 6.24) was based on a detection limit of $1 \times 10^{-5}{ }_{\mu} \mathrm{Ci} / \mathrm{ml}(10,000 \mathrm{pCi} / \mathrm{L})$ (Brown 1962b). The leading edge of the tritium plume was interpreted to have nearly reached the Columbia River, with detectable concentrations averaging $7 \times 10^{-5} \mu \mathrm{Ci} / \mathrm{ml}(70,000 \mathrm{pCi} / \mathrm{L})$ in we 11 699-20-E12 near the river. Samples collected from springs along the banks of the Columbia River did not contain tritium in concentrations above the detection limit.

The distribution of average tritium concentrations for July through December 1962, illustrated in Figure 6.25 (Brown 1963), covers a smaller area than that shown on the first map provided by Brown (1962b) for the previous reporting period (the first 6 months of 1962). Both of the plumes from the 200 -East and 200-West Areas, defined by the $1 \times 10^{-5} \mu \mathrm{Ci} / \mathrm{ml} \quad(10,000 \mathrm{pCi} / \mathrm{L})$ contour and higher concentrations, are smaller.

The extent of tritium in the unconfined aquifer interpreted for January through June 1963 (Figure 6.26) was further reduced from the previous reporting period (Haney 1963). Exceptions were noted in wells 699-41-23 and 699-40-1, where intermittent detectable concentrations of tritium were present. These wells were mapped as isolated zones of contamination, but probably were associated with the plume from the 200-East Area. Analytical results for tritium during this reporting period were based on a detection limit of $1 \times 10^{-5} \mu \mathrm{Ci} / \mathrm{ml}(10,000 \mathrm{pCi} / \mathrm{L})$. Reference was made to lowering the detection limit to $2 \times 10^{-6} \mu \mathrm{Ci} / \mathrm{ml}(2,000 \mathrm{pCi} / \mathrm{L})$ for routine analyses and to $1 \times 10^{-7}$ to $5 \times 10^{-9} \mu \mathrm{Ci} / \mathrm{ml}(100$ to $5 \mathrm{pCi} / \mathrm{L})$ for nonroutine analyses of samples from wells to better define the outer edge of the plume. 


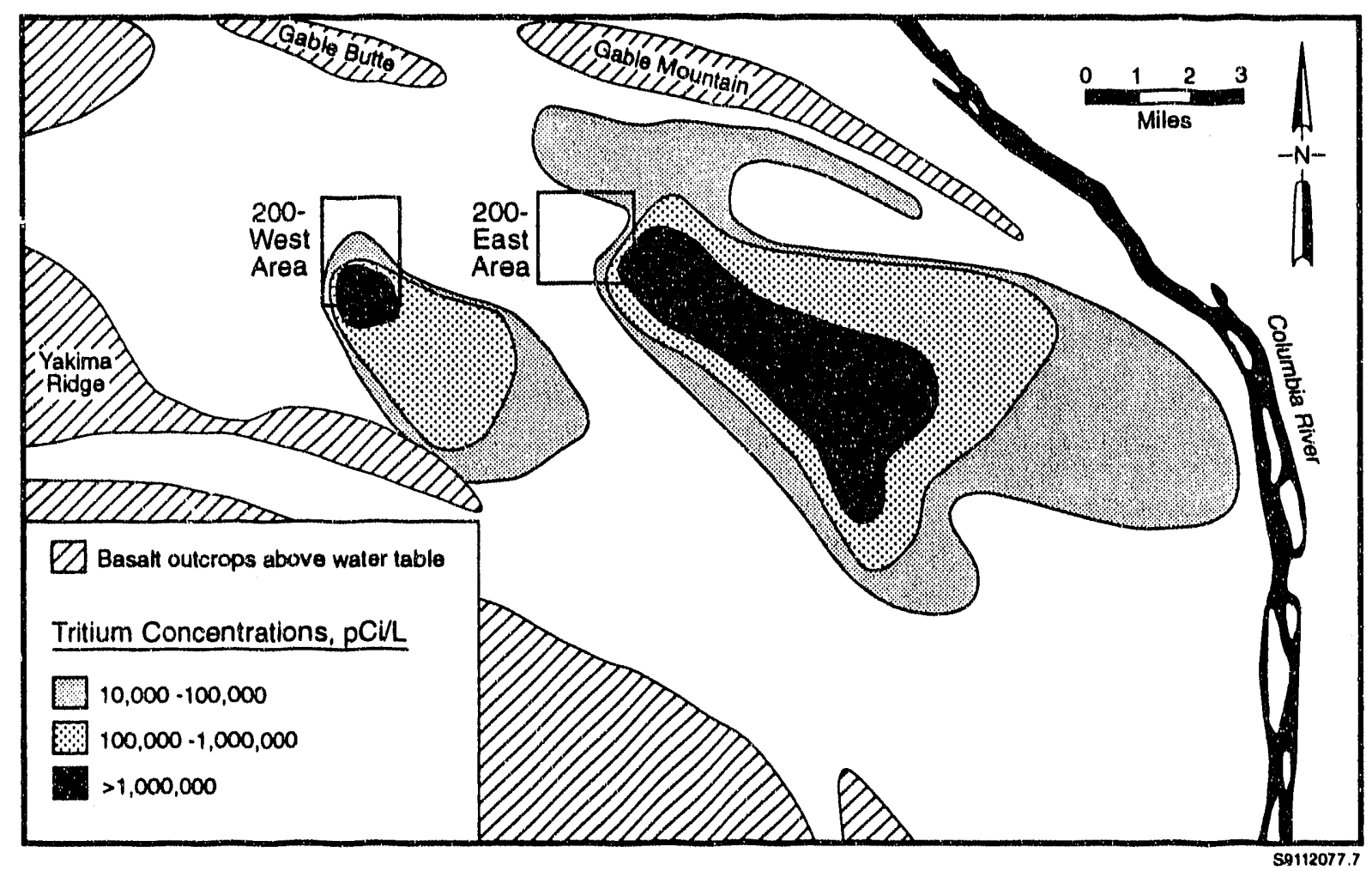

EIGURE 6.24. Distribution of Average Tritium Concentrations in the Unconfined Aquifer During January Through June 1962 (after Brown 1962b)

The distribution of average tritium concentrations in the unconfined aquifer during January through December 1964 reported in Brown (1964) was essentially the same as that for the previous reporting period. However, the area affected by discharges to $B$ Pond was interpreted as having expanded slightly, and the tritium concentrations near the river were thought to be affected by mixing of contaminated ground water and clean river water. Interpretation of the distribution of tritium concentrations was based on the lower detection limits referenced in Brown and Haney (1964).

Brown and Haney (1964) presented a summary of the early tritium monitoring data, one year after tritium was reported as a fission product. The distribution of tritium in the unconfined aquifer for July through December 1963 is shown as having reached the Columbia River (Figure 6.27). The distribution of monitoring wells that the interpretation is based on is included in 


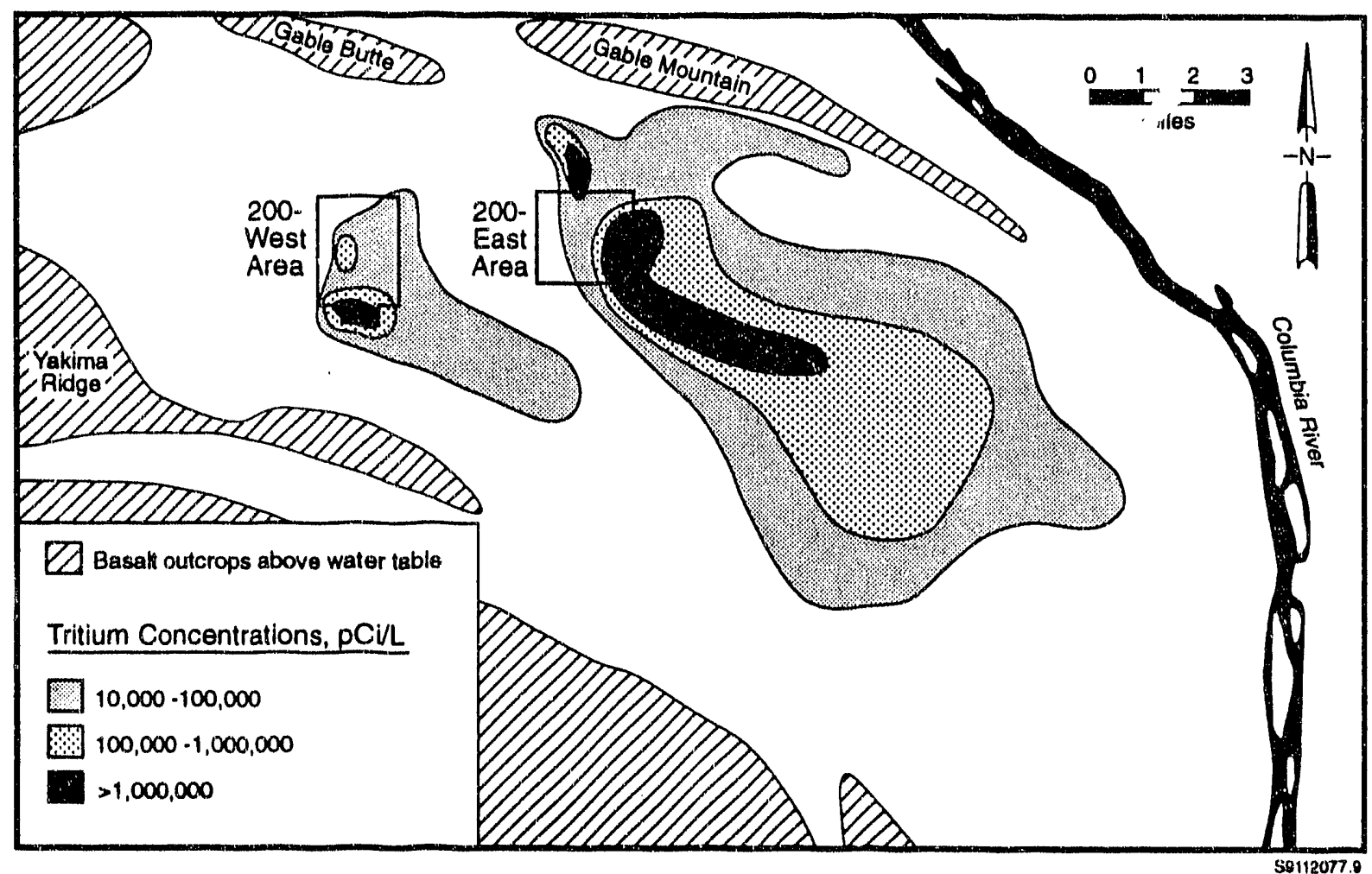

FIGURE 6.25. Distribution of Average Tritium Concentrations in the Unconfined Aquifer During July Through December 1962 (after Brown 1963)

Figure 6.27. In addition to the monitoring results for tritium, Brown and Haney (1964) included a section on travel-time estimates in their report. Their estimates of travel time for tritium were based on the first appearance or arrival of tritium concentrations near the detection limit. However, in the monitoring data for wells near the Columbia River, the appearance of tritium and other radionuclides was sporadic. Brown and Haney (1964) attributed the sporadic measurements to the fact that the concentrations were close to the detection limit and to fluctuations of the river stage.

Brown and Haney (1964) identified three sources of uncertainty for the estimates of arrival time at the wells and the river: 1) variations in measured concentrations because radionuclide concentrations varied with depth (at that time, many of the wells were open to a wide interval); 2) the relatively sparse monitoring well coverage at some locations (there were not very 


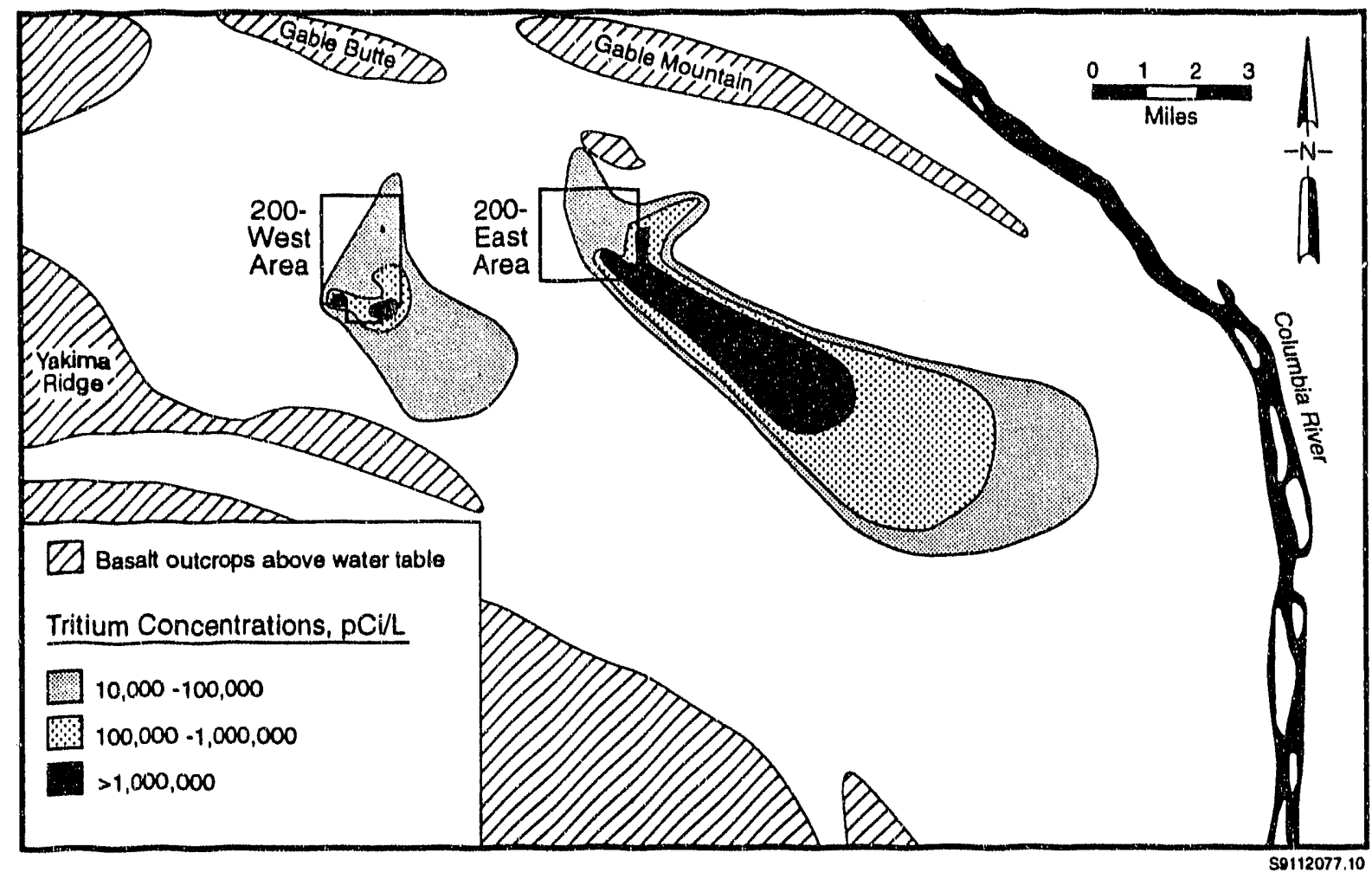

FIGURE 6.26. Distribution of Average Tritium Concentrations in the Unconfined Aquifer During January Through June 1963 (after Haney 1963)

many wells located near the river at the time); and 3) possible inaccuracies in the flow system interpretation (and also problems with ground-water monitoring measurements). As will be shown later in this section, the limited number of monitoring wells contributed the most to uncertainty in estimates of arrival time. Brown and Haney's (1964) stated philosophy for estimating travel times was to err on the conservative side when anomalies in the monitoring data were evident. This meani that intermitient concentrations were used to estimate travel times. A summary of the interpretation of travel times in the unconfined aquifer by Brown and Haney (1964) is illustrated in Figure 6.28. These trave1-time interpretations were based on tritium and gross beta (ruthenium-106) monitoring data.

The interpreted distribution of tritium remained essentially unchanged between 1963 and 1965 (Brown 1965). As with gross beta monitoring results for 


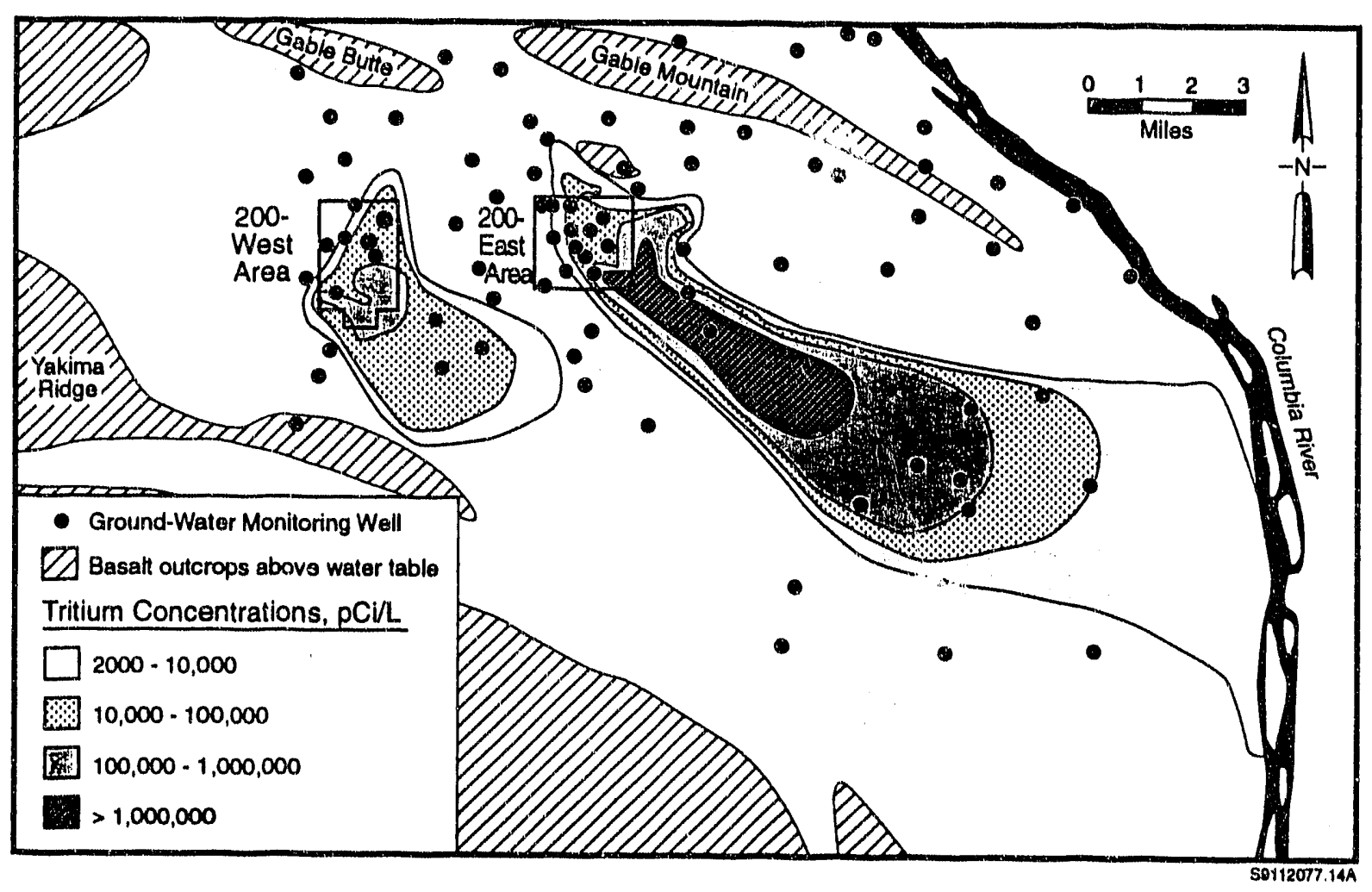

FIGURE 6.27. Distribution of Average Tritium Concentrations in the Unconfined Aquifer During July Through December 1963 (after Brown and Haney 1964)

1965 (Figure 6.20), the distribution of average tritium concentrations in the unconfined aquifer from July through December 1965 (Figure 6.29) reported by Eliason (1966a) was considerably different from that during the previous reporting period, although the same contour intervals and detection limit $(2 \mathrm{pCi} / \mathrm{L})$ were used. The expanded zone of tritium contamination was based on measurements showing tritium levels slightly above the detection limit in several additional wells.

Eliason (1966a) reported on analyses of samples from wells drilled to monitor the confined aquifers, although the specific confined aquifers that were sampled were not listed. The maximum tritium concentration observed was $2500 \mathrm{pCi} / \mathrm{ml}(2,500,000 \mathrm{pCi} / \mathrm{L})$ in well 699-30-31R at a depth of 300 feet. This concentration was consistent with the $2300 \mathrm{pCi} / \mathrm{ml}(2,300,000 \mathrm{pCi} / \mathrm{L})$ concentration measured in the same well during the previous reporting period. 


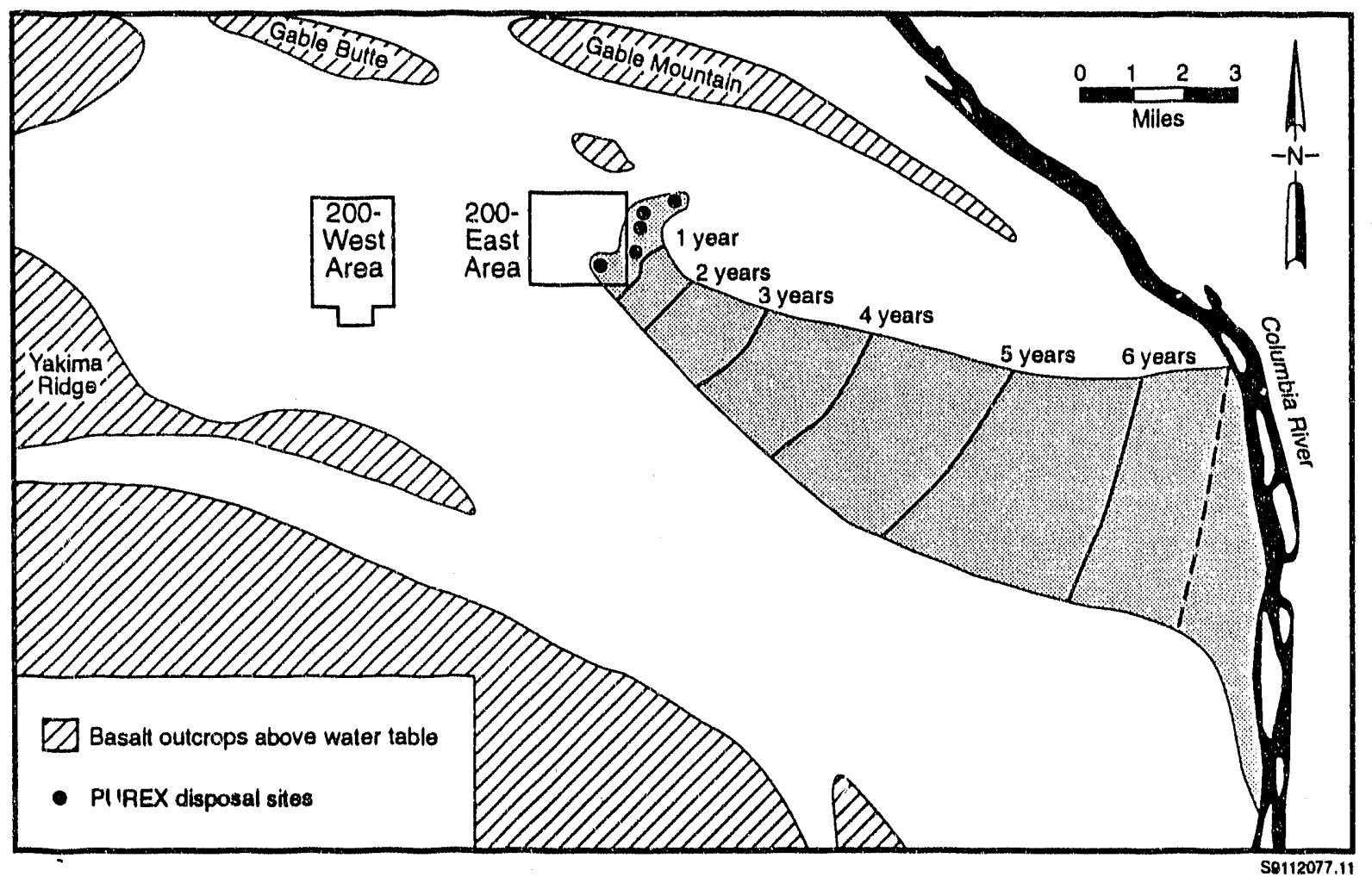

FIGURE 6.28. Estimated Distribution of Travei Time for Tritium and Ruthenium-106 Between PUREX Discharges' (in the 200-East Area) and the Columbia River (after Brown and Haney 1964)

Eliason (1967b) mapped the tritium plume as having reached the Columbia River. The distribution of tritium (Figure 6.30 ) includes a zone of detectable concentrations ( 2 to $4 \mathrm{pCi} / \mathrm{ml} ; 2000$ to $4000 \mathrm{pCi} / \mathrm{L}$ ) that appear intermittently in wells attributed to river fluctuations that affected water levels and concentrations measured in wells. The area covered by the 100,000 to $1,000,000 \mathrm{pCi} / \mathrm{L}$ concentration range increased over the previous 6 -month period. Eliason (1967b) attributed this increase in tritium activity to disposal of condensate wastes from B Plant.

Essig (1968) reported a much smaller extent of tritium contamination in the unconfined aquifer during July through December 1967 (Figure 6.31). The extent of tritium shown in Figure 6.31 differs from that shown in Figure 6.27 because, by 1967, additional monitoring wells had been drilled between the leading edge of the plume and the river. No specific explanation was provided 


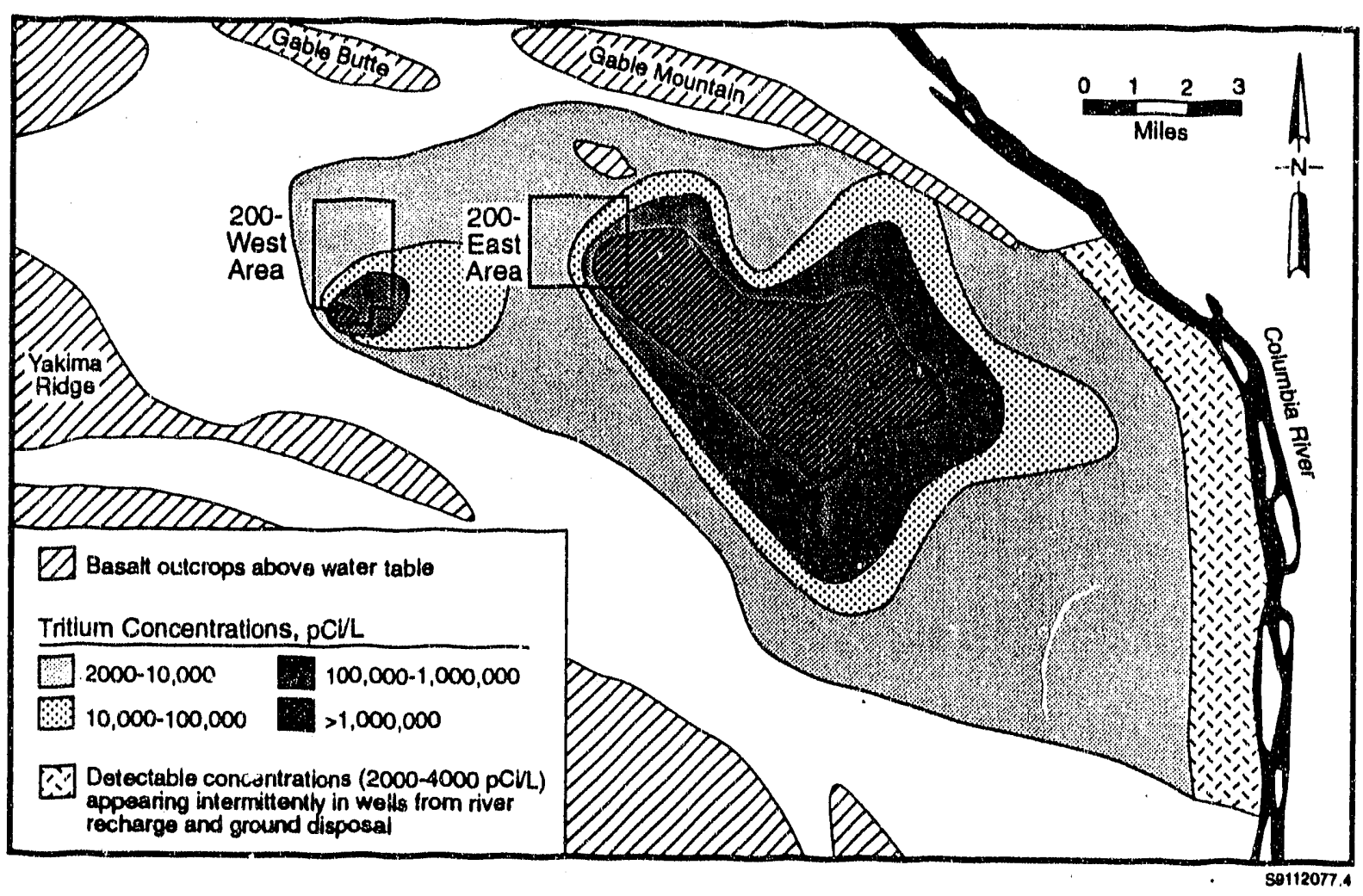

FIGURE 6.29. Distribution of Average Tritium Concentrations in the Unconfined Aquifer During July Through December 1965 (after Eliason 1966a)

for the different interpretation of the tritium (and gross beta) plume, other than that responsibility for reporting had shifted to a different organization. However, monitoring data from the additional monitoring wells demonstrated that the extent of contamination was less than previnusly thought. Interpretation of the tritium monitoring data for 1968 through 1972 remained essentially the same with some minor changes (Kipp 1972). During this time, the tritium plume was not interpreted to have reached the river.

Kipp (1975) included data from the 200 Areas and a number of new monitoring wells; these data changed the interpretation of the tritium distribution in the unconfined aquifer (Figure 6.32). The first change consisted of joining the tritium plumes in the 100 Areas with the plume originating from the 200-East Area. Previously, these two plumes were separated in the area between Gable Mountain and Gable Butte (Gable Gap), indicating separate 


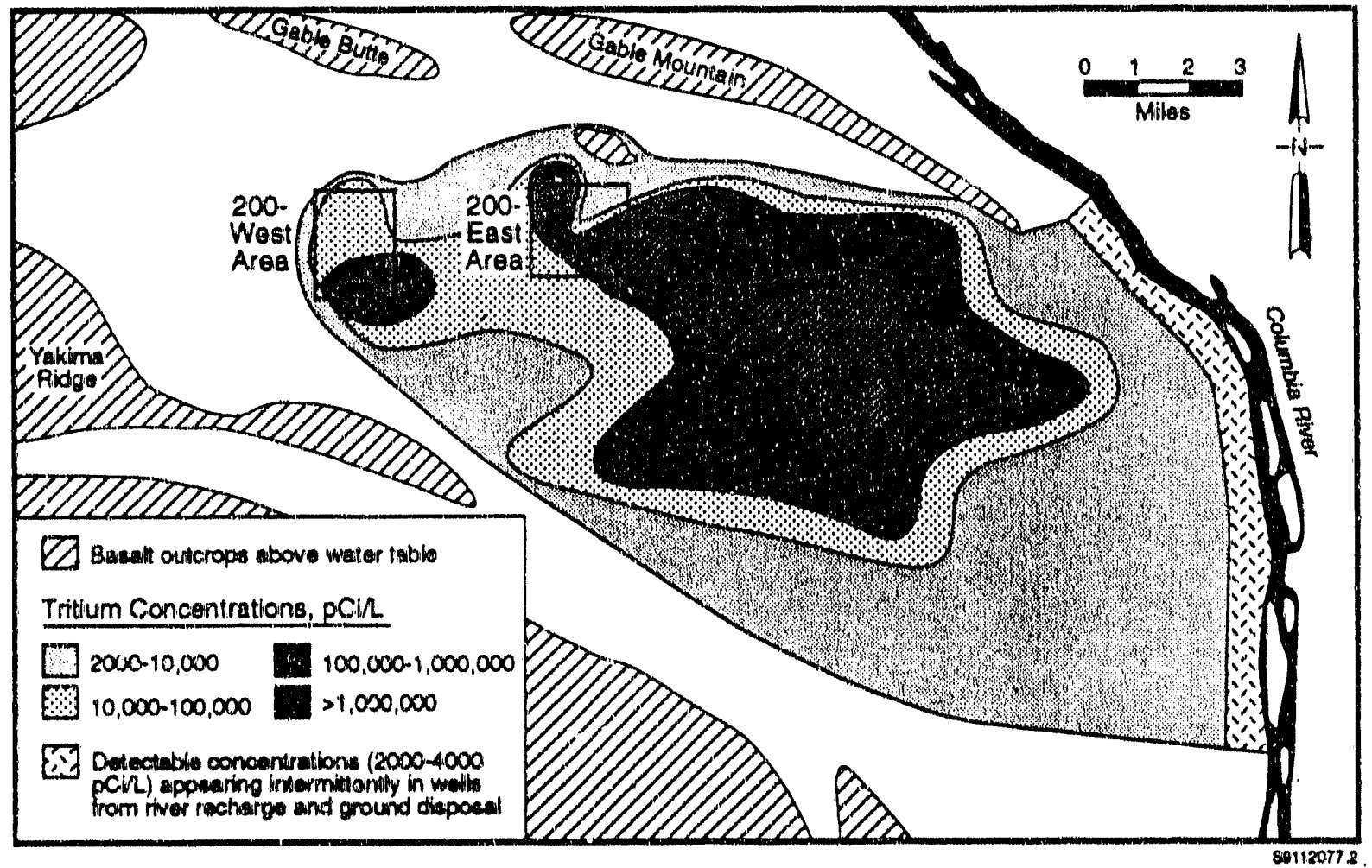

EIGURE 6.30. Distribution of Average Tritium Concentrations in the Unconfined Aquifer During July Through December 1966 (after Eliason 1967b)

sources. According to the iliterpretation in Kipp (1975), the plume to the north of Gable Gap had tritium both from 100-Area and 200-East-Area sources. A second change in the interpretation of the tritium plume was in the area of the Washingtor Public Power Supply System (Supply System) where several wells were sampled during pumping for construction water at the Supply System Number 2 reactor. Tritium was detected in several monitoring wells, and the tritium plume was extended to the Supply system location.

Raymond et a). (1976) reported that the detectable front of the tritium plume in the unconfined aquifer from the 200-East Area was interpreted to have moved slightly toward the Columbia River. The tritium plume was not mapped as having reached the river during this reporting period. 


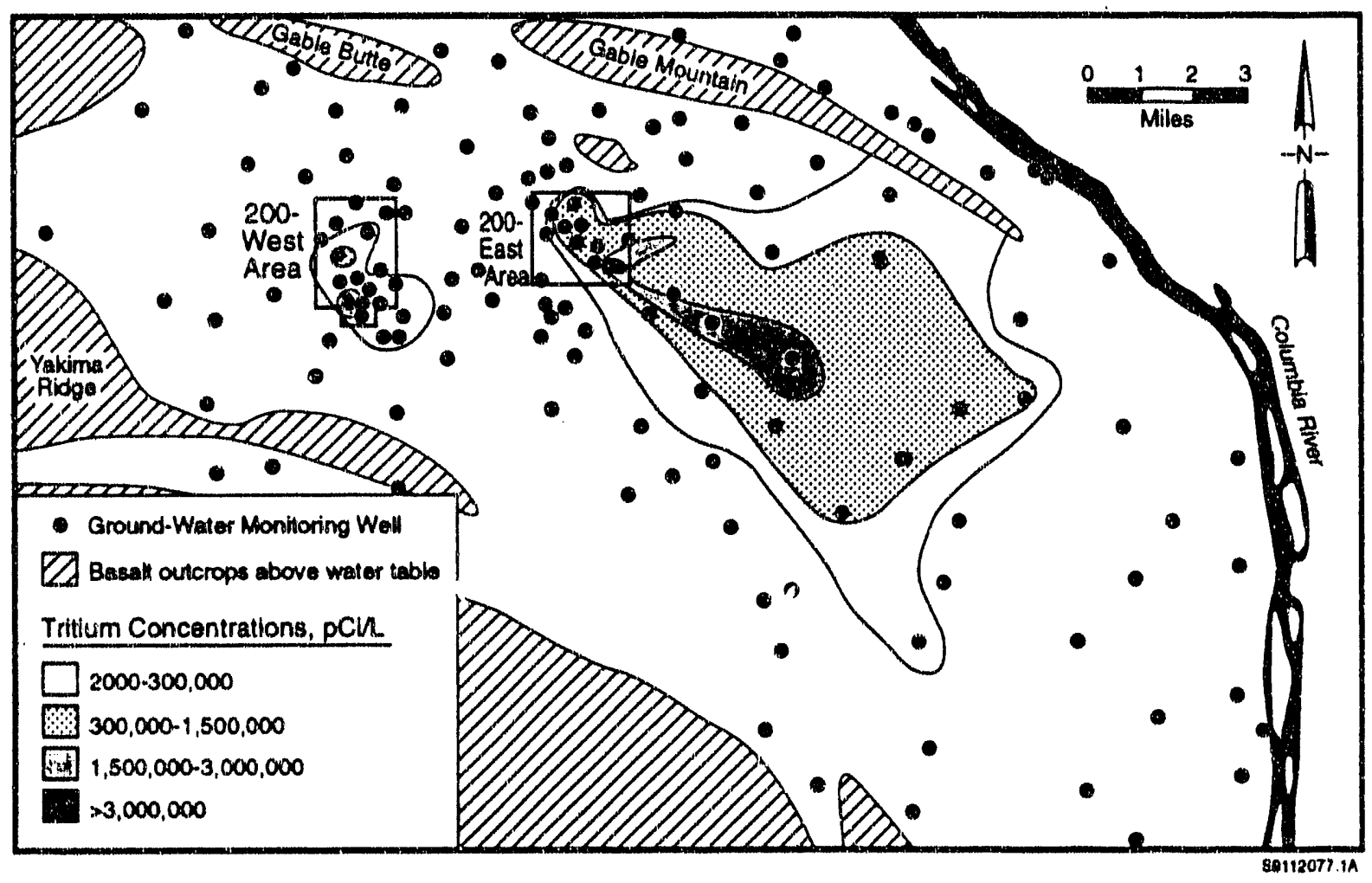

EIGURE 6.31. Distribution of Average Trftium Concentrations in the Unconfined Aquifer During July Through December 1967 (after Essig 1968)

Myers, Fix and Raymond (1977) reported that, based on monitoring data from well 699-40-1 (Figure 6.1), the tritium plume was expected to reach the Columbia River "in the near future." The leading edge of the tritium plume, defined by the $30 \mathrm{pCi} / \mathrm{ml}$ isopleth $(30,000 \mathrm{pCi} / \mathrm{L})$, was mapped as having nearly reached the river.

The tritium concentration history in well 699-40-1 11lustrates the results of the well remediation effort described by Eddy, Myers and Raymond (1978); McGhan (1978); and in Section 5.2 of this report. Before 1974, tritium concentrations measured in the well were highly variable. This variation resulted from collecting samples at different depths in an open well. As described in Section 5.2.1, the well was shortened during 1974 to sample approximately the upper 30 feet in the aquifer. The variability in the reported concentrations decreased dramatically (Figure 6.1); however, the 


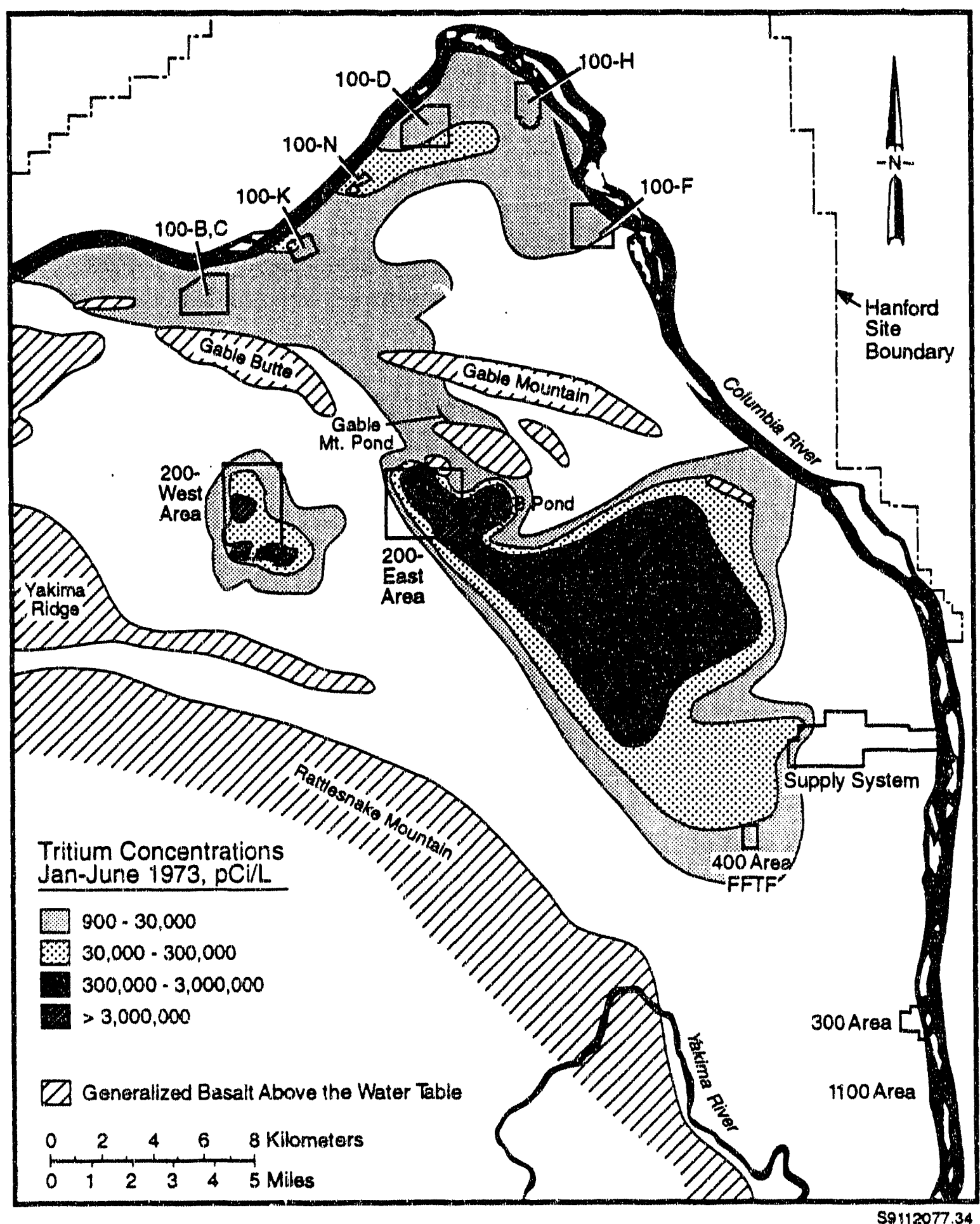

EIGURE 6.32. Distribution of Average Tritium Concentrations in the Unconfined Aquifer During January Through June 1973 (after Kipp 1975) 
measured concentrations of tritium increased because the highest concentrations are in the upper part of the aquifer.

Staff in a consulting firm, SEARCH Technical Services, Inc. (SEARCH), interpreted the monitoring data from we11 699-40-1 differently in that they assumed the data indicated periodic arrival of high concentrations of tritium from PUREX in a hypothetical high-permeability channel extending from the 200-East Area to the Columbia River (Buske and Josephson 1986). However, the USGS (1987) cuicluded that problems with sampling an open borehole and the effects of the subsequent well remediation are more feasible explanations of the increases in measured tritium concentrations.

Myers (1978) reported that the tritium plume to the southeast of the 200-East Area continued to shrink. The tritium plume had changed little from the previous year, although the leading edge of the plume, defined by the $30 \mathrm{pCi} / \mathrm{ml}(30,000 \mathrm{pCi} / \mathrm{L})$ isopleth, was mapped as having reached the Columbia River (Figure 6.33) near well 699-40-1. This interpretation was based on increasing concentrations in we11 699-40-1. The time required for the $112,000 \mathrm{pCi} / \mathrm{L}$ tritium concentration to reach the river in 1976-1979 represents the average travel time for tritium to migrate from the 200-East Area to the river (see p. 6.3). This estimate differs from the travel times previously estimated by Brown and Haney (1964), which were for first arrival of detectable concentrations (see Figure 6.27).

Eddy and Wilbur (1980) reported that the tritium plume had reached the Columbia River before 1979. They stated that tritium was discharging to the river, but impacts from this discharge were not discernable by comparing water concentrations at upstream and downstream locations in the Columbia River. Their interpretation of the tritium plume was different from previous years, with the map showing concentrations between 30 and $300 \mathrm{pCi} / \mathrm{ml}(30,000$ to $300,000 \mathrm{pC} i / L$ ) being discharged to the river (Figure 6.34).

The interpretations of the tritium plume during 1980 to 1984 (Eddy and Wilbur 1981; Eddy, Prater and Rieger 1983; Prater et a1. 1984; Cline, Rieger and Raymond 1985) differ from year to year. These changes in the interpretation of the tritium monitoring data (as well as those from previous years) 


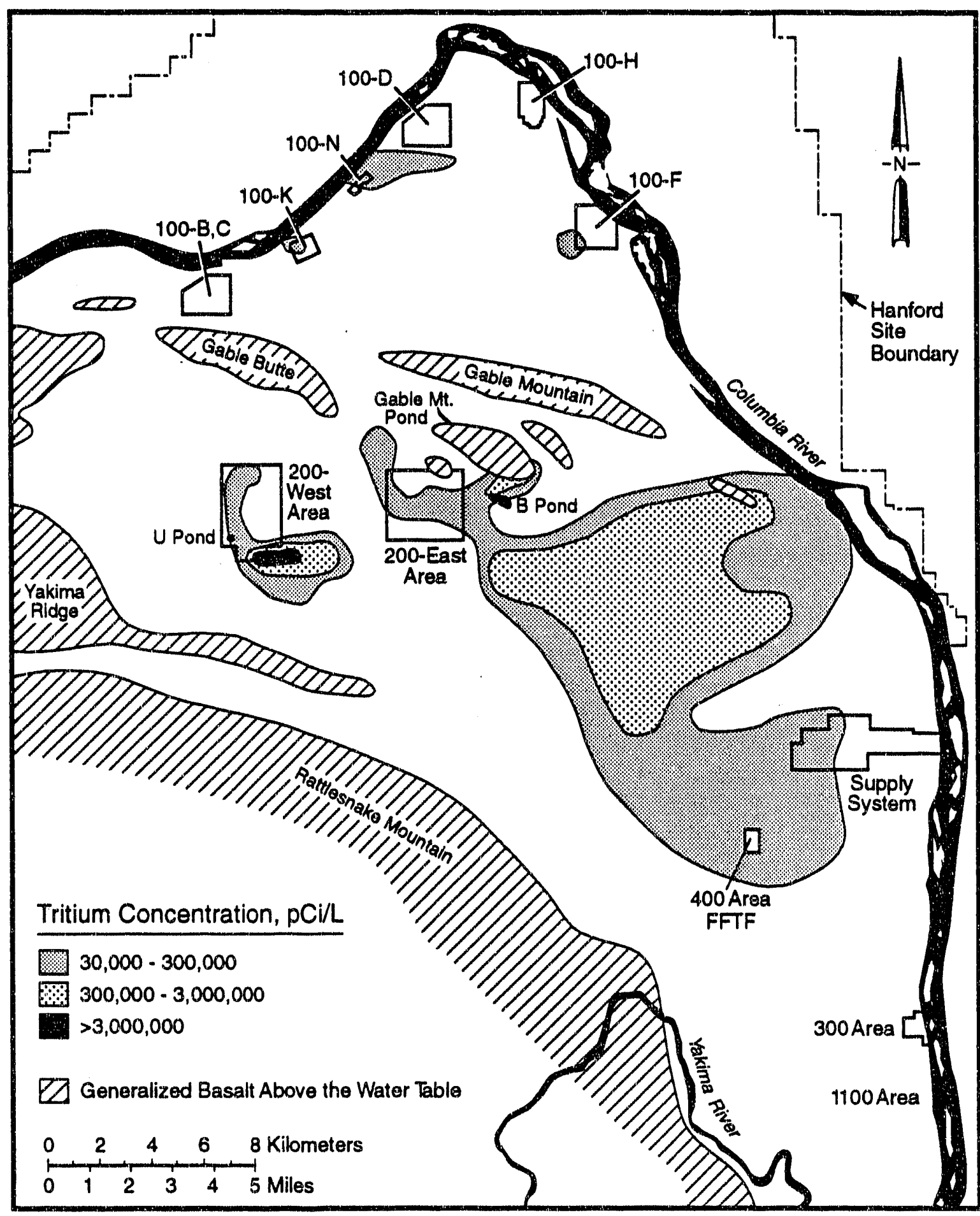

$\$ 9112077.33$

FIGURE 6.33. Distribution of Average Tritium Concentrations in the Unconfined Aquifer During January Through December 1977 (after Myers 1978) 


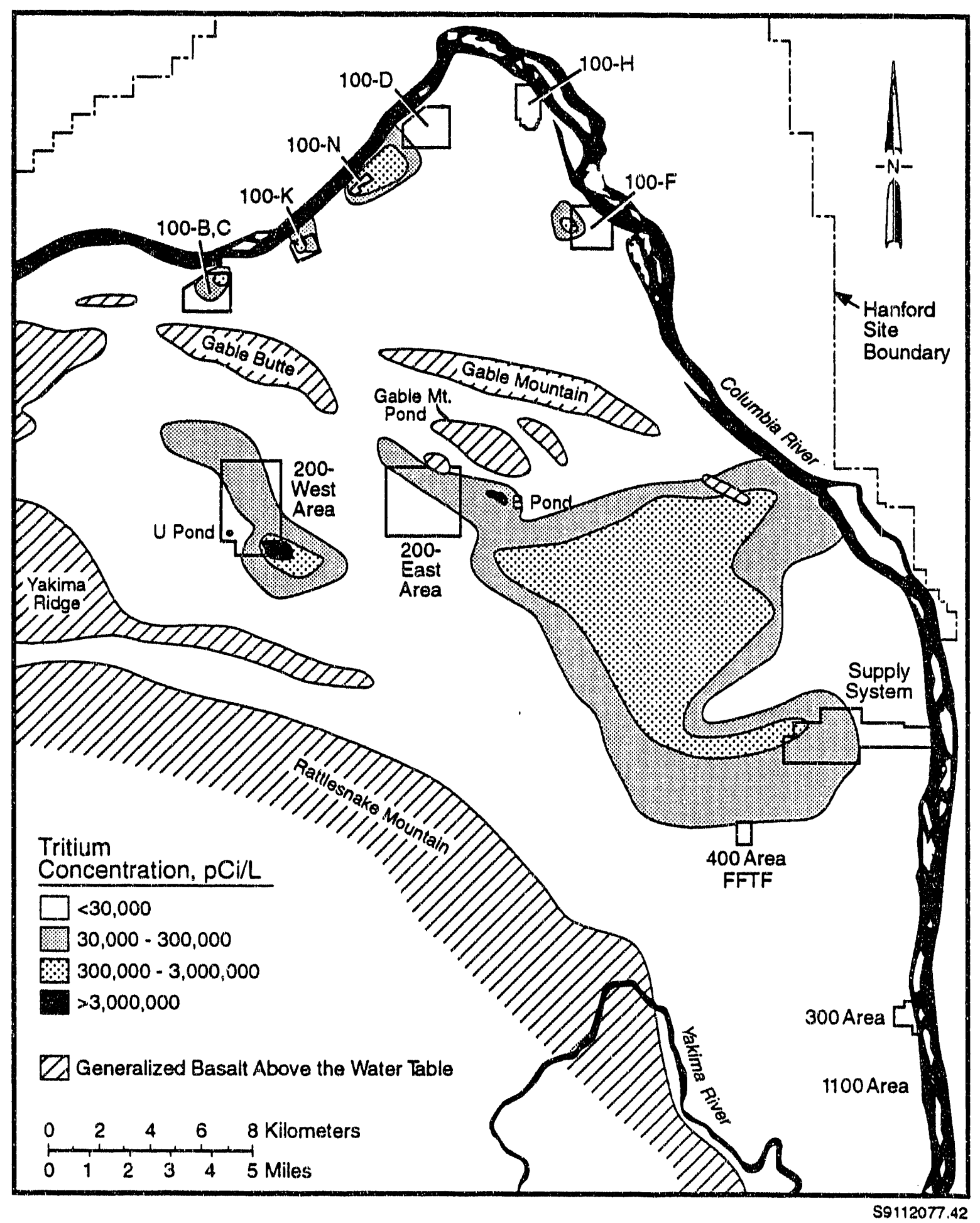

EIGURE 6.34. Distribution of Average Tritium Concentrations in the Unconfined Aquifer During 1979 (after Eddy and Wilbur 1980) 
arose from slight differences in reported concentrations and from different investigators providing the interpretation. All of the maps presented in the annual reports were interpolated by hand. The tritium plume was mapped as having reached the river, and the $300 \mathrm{pCi} / \mathrm{ml}(300,000 \mathrm{pCi} / \mathrm{L})$ isopleth was approaching the river.

Price (1986) was the first annual monitoring report to include groundwater monitoring results with results of the other types of environmental monitoring performed at the Hanford Site. The interpretation of the tritium monitoring data was different from previous years; contour intervals of $20,000,200,000$, and 2,000,000 pCi/L were used (Figure 6.35). Price (1986) interpreted the $200,000 \mathrm{pCi} / \mathrm{L}$ isopleth as having reached the Columbia River. It is difficult to determine how much the change in the concentration contours (from $300,000 \mathrm{pCi} / \mathrm{L}$ to $200,000 \mathrm{pCi} / \mathrm{L}$ ) reflects arrival of higher concentrations at the river versus continued migration of the tritium plume toward the river. The first wells downgradient of the discharge facilities for the PUREX crib (wel1s 699-33-42 and 699-34-42) began to show increasing tritium concentrations, indicating that tritium first arrived at these wells 2 years after PUREX restarted in 1983.

PNL (1987) reported that during 1986, tritium concentrations continued to increase significantly at two wells downgradient of the PUREX liquid waste discharge facilities. Interpretation of the tritium monitoring data illustrates a second plume of higher concentrations resulting from restart of PUREX (Figure 6.36).

Jaquish and Mitchell (1988) reported that the tritium plume to the southeast of the 200-East Area (Figure 6.37) continued to discharge to the Columbia River near the Hanford townsite. In addition, the leading edge of the plume was observed to be moving farther south, and the new plume of higher concentrations resulting from restart of PUREX operations in December 1983 continued to move to the southeast.

Jaquish and Bryce $(1989,1990)$ reported that the tritium plume to the southeast of the 200-East Area continued to move to the east-southeast and to discharge to tho Columbia River. The second plume resulting from restart of 


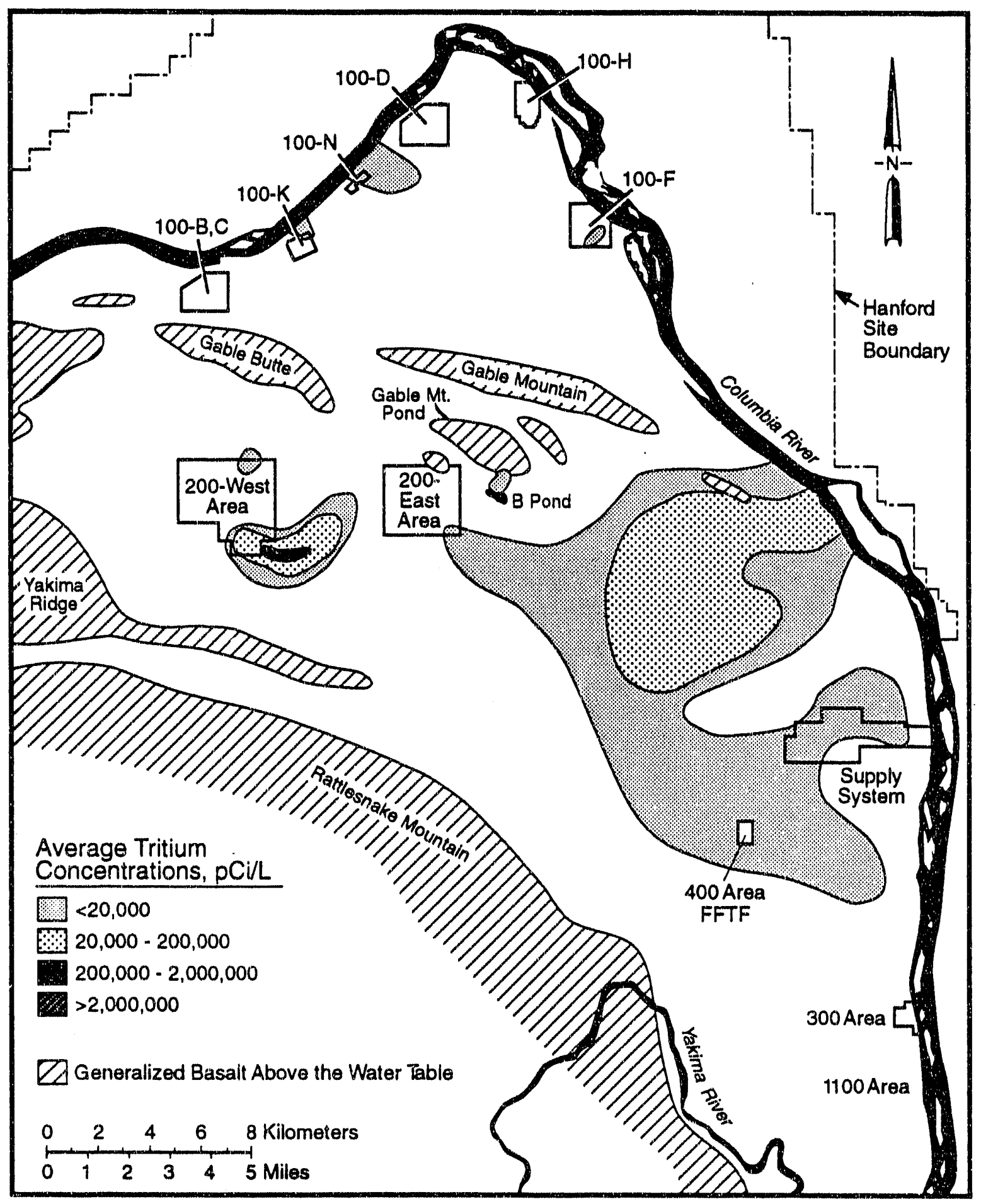

\$9112077.27

EIGURE 6.35. Distribution of Average Tritium Concentrations in the Unconfined Aquifer During 1985 (after Price 1986) 


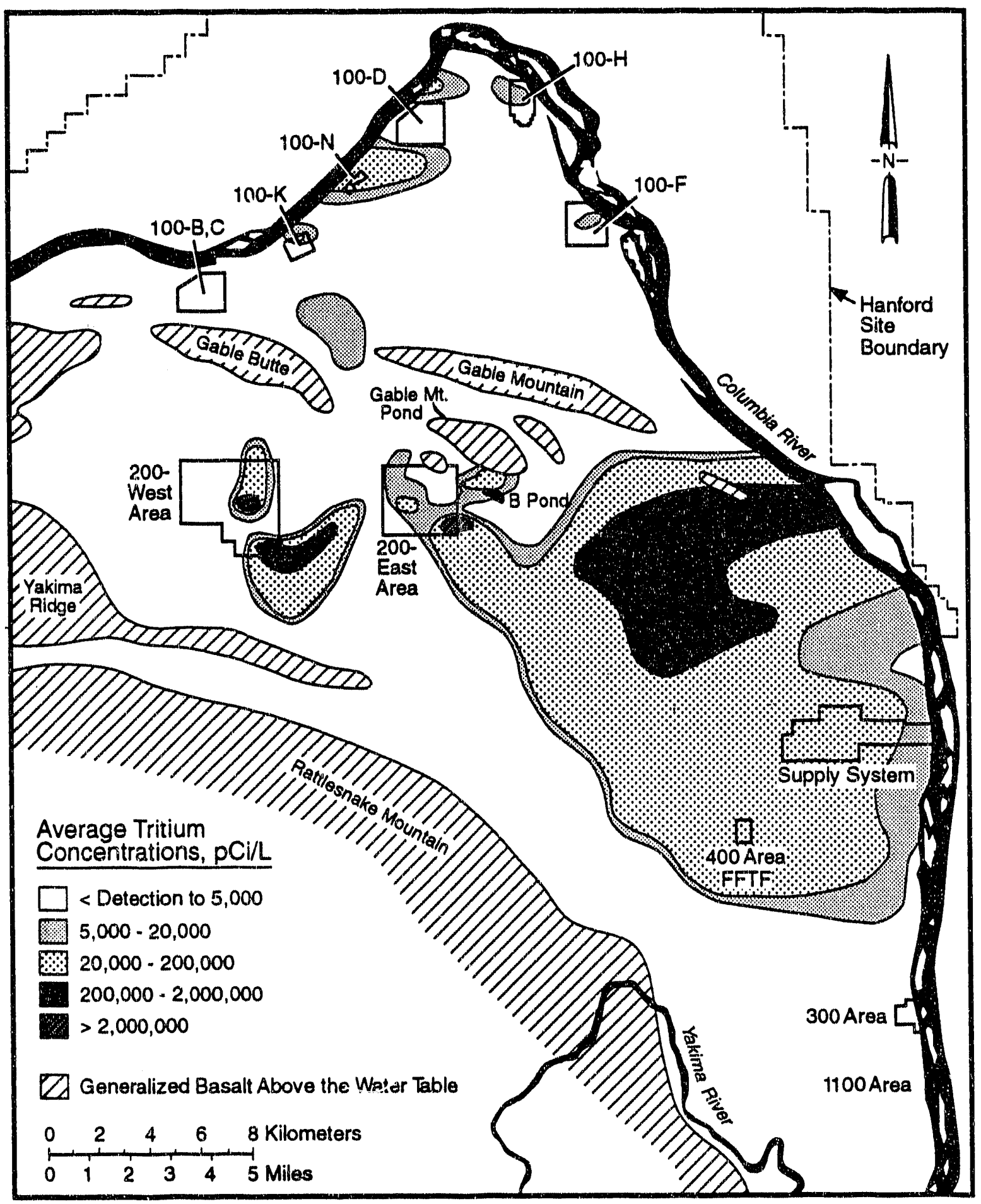

59112077.31

FIGURE 6.36. Distribution of Average Tritium Concentrations in the Unconfined Aquifer During 1986 (PNL 1987) 


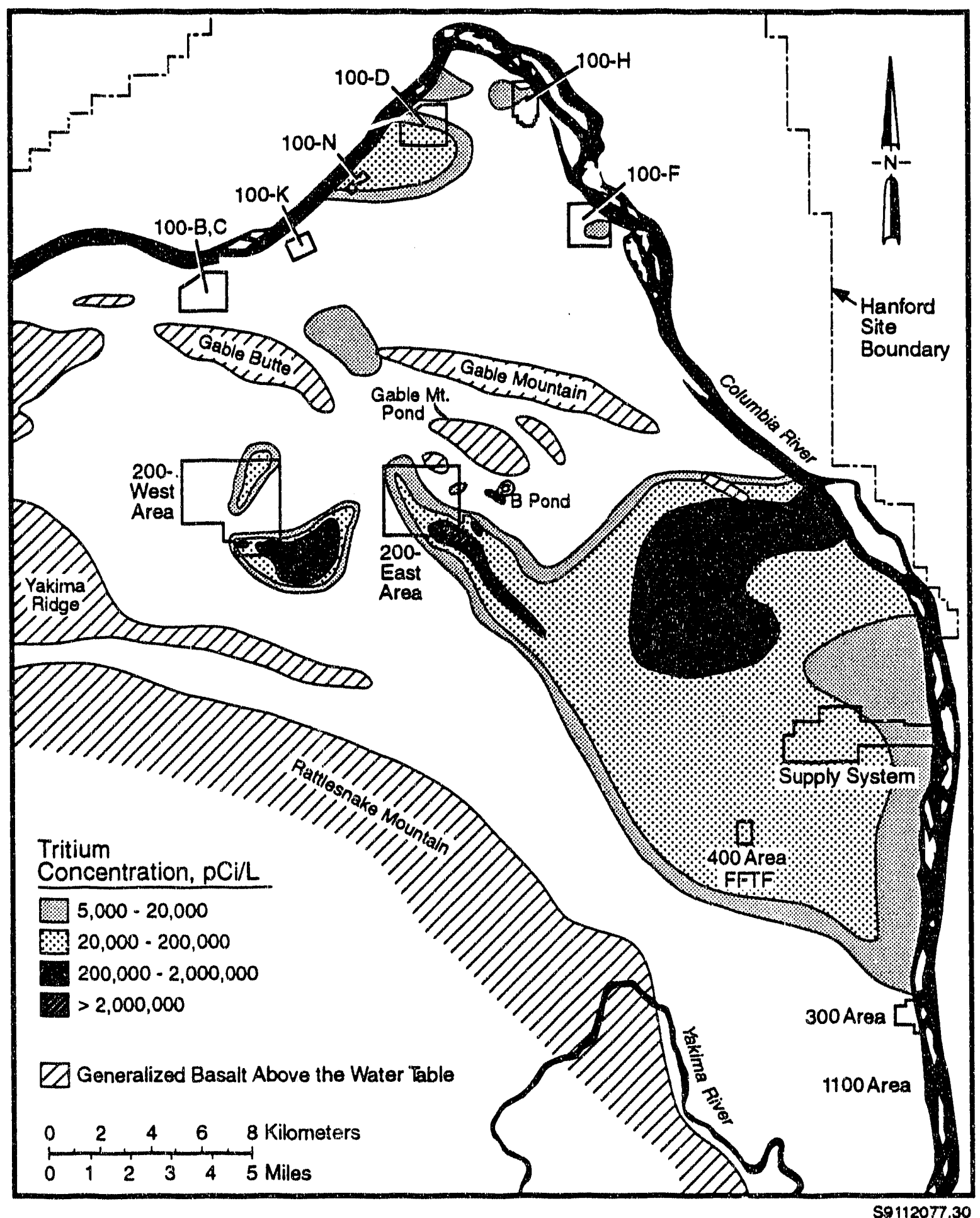

FIGURE 6.37. Distribution of Average Tritium Concentrations in the Unconfined Aquifer During 1988 (after Jaquish and Mitchell 1988) 
PUREX operations in December 1983 continued to expand to the southeast, and concentrations near the source continued to increase.

An outside consulting firm, SEARCH, hypothesized that the time for wastes from the PUREX facility to travel to the Columbia River in a high-permeability channel was on the order of 2.5 years (Buske and Josephson 1986). In a review of the work by SEARCH and Hanford Site contractors, the USGS (1987) reported a summary of ground-water monitoring data for the unconfined aquifer and estimated a 13-year average travel time for contaminants to migrate from the PUREX cribs to the Columbia River (Figure 6.38). However, the USGS stated that because of uncertainties in interpreting some of the data, the average travel time probably ranged from 10 to 20 years. The USGS arrived at the 13-year travel time by assuming, on the basis of discharge records, that most of the tritium was discharged to the aquifer from the PUREX cribs after 1963. An arrival time at the Columbia River of 1976 gave the 13-year estimate.

In addition to their review of the SEARCH travel-time predictions, the USGS concluded that the available geologic, hydrologic, and water chemistry data neither confirm nor refute the existence of the hypothetical channel (USGS 1987). However, the USGS stated that an alternative hypothesis to the channel is possible: broad areas of high permeability with local ground-water discharge near the Hanford townsite.

Review of ground-water monitoring data for the unconfined aquifer showed that the tritium plume reached the Columbia River between 1976 and 1979 (Myers 1978; Freshley and Graham 1988). Assuming that most of the tritium in the ground water between the 200-East Area and the Columbia River is from PUREX operations, which began in 1956 , arrival of the 30 to $300 \mathrm{pCi} / \mathrm{ml}(30,000$ to $300,000 \mathrm{pCi} / \mathrm{L})$ tritium isopleth at the river in the 1976 to 1979 period represents an average travel time of 20 to 23 years. The $112,000 \mathrm{pCi} / \mathrm{L}$ iritium concentration used to estimate the average travel time from the PUREX cribs to the river is approximately half the maximum sustained concentration in well 699-40-1 (Price 1986), which is near the river (Figure 6.1). Higher concentrations of tritium (200 to $300 \mathrm{pCi} / \mathrm{ml}$ [200,000 to $300,000 \mathrm{pCi} / \mathrm{L}])$ were interpreted to begin discharging to the Columbia River in 1985 (Price 1986). 


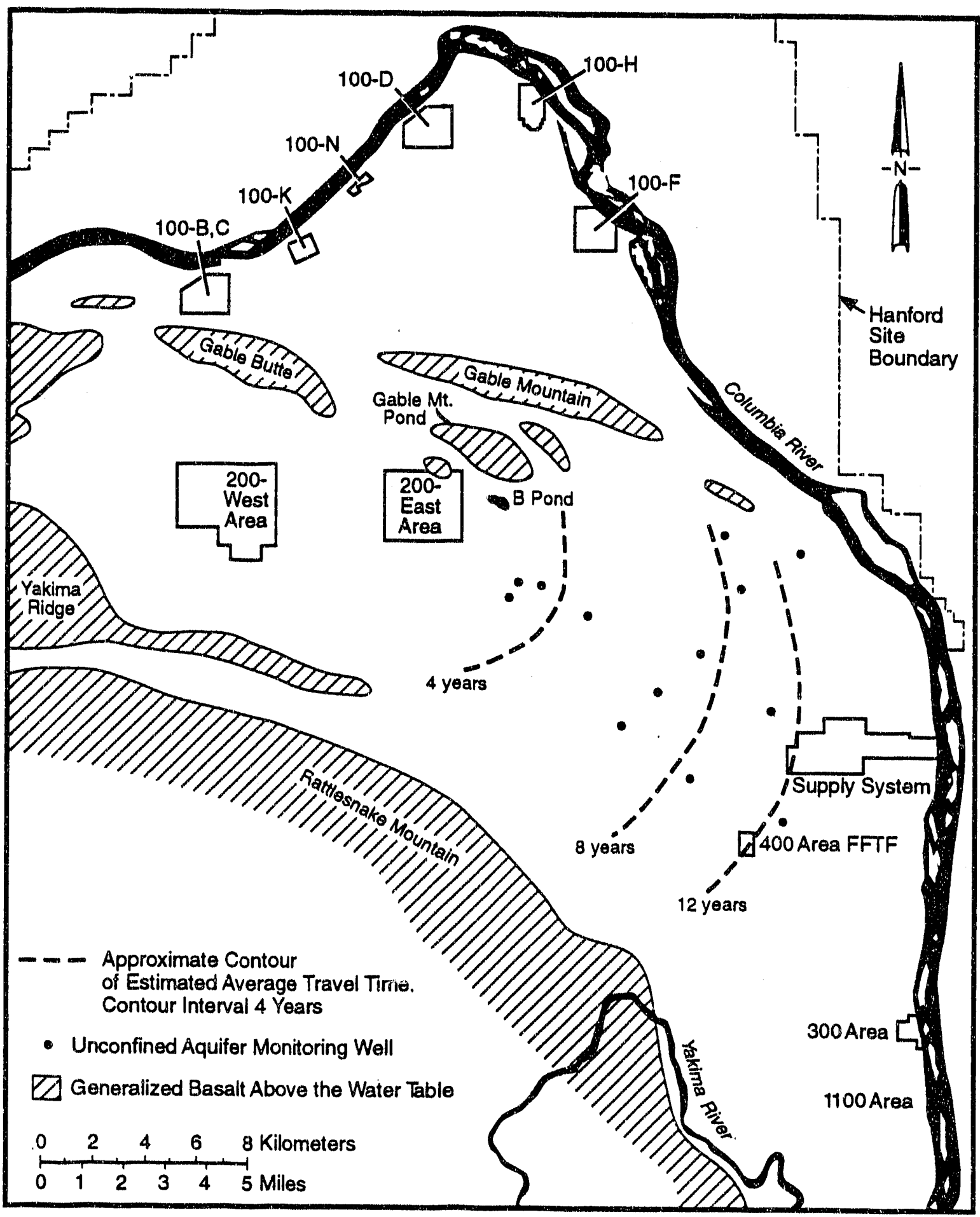

S9112077.20

EIGURE 6.38. Average Travel Times for Tritium and Nitrate from the 200-East Area to the Columbia River, Estimated by the USGS (after USGS 1987) 


\section{Iodine-129}

Less information is available regarding concentrations of iodine-129 in the unconfined and confined aquifers at the Hanford Site than for gross beta and tritium. The monitoring reports generally include listings of iodine-129 monitoring data, but do not provide map interpretations. As with tritium, iodine-129 is generally not retarded by chemical interactions and therefore generally travels at the same velocity as ground water. It is regarded to be an excellent tracer and has a very long half-life of about 16 million years. A small amount of naturally occurring iodine-129 is associated with all iodine present in the environment. However, since the 1940s, additional iodine has been present in the Hanford Site environment from operation of reactors, reprocessing of fuels from the reactors, and fallout from offsite nuclear weapons testing.

Raymond et a1. (1976) reported concentrations of iodine-129 in Hanford Site ground water measured during 1975. These measurements of iodine-129 are the result of 10 years of cooperative research by the Atlantic Richfield Hanford Company (ARHCO) and PNL to develop analytical methods for detecting low levels of selected radionuclides. Iodine-129 was reported to have essentially the same distribution as other contaminants, such as tritium, in the unconfined aquifer.

During 1976, water samples from 10 wells monitoring the unconfined aquifer were analyzed for iodine-129 (Myers, Fix and Raymond 1977). Results of the analyses (Table 6.4) indicate that iodine-129 behaves the same as other contaminants; concentrations were highest near the 200-Area sources and decreased as they move toward the Columbia River.

Myers (1978) also reported iodine-129 concentrations for ground water in the unconfined aquifer. The maximum concentration observed in 10 wells was $1 \mathrm{pCi} / \mathrm{L}$ in well 699-27-8, which is located between the Columbia River and the 200-East Area.

Erdy and Wilbur (1980) reported that during 1979 more wells were sampled for iodine-129 than in previous years. The distribution of wells for iodine-129 analyses is illustrated in Figure 6.39. Concentrations reported 
TABLE 6.4. Iodine-129 Concentrations in Selected Wells Monitoring the Unconfined Aquifer During 1976 (after Myers, Fix and Raymond 1977)

\begin{tabular}{lcc} 
Well & Date of Sample & $\begin{array}{c}\text { Iodine-129 } \\
\text { concentration } \\
(\mathrm{pCi} / L)\end{array}$ \\
\hline $699-$ S29-E12 & $4 / 8 / 76$ & 0.00005 \\
$699-S 3-E 12$ & $4 / 8 / 76$ & 0.00008 \\
$699-8-17$ & $4 / 8 / 76$ & 0.1 \\
$699-27-8$ & $4 / 8 / 76$ & 1 \\
$699-32-22$ & $4 / 8 / 76$ & 2 \\
$699-33-56$ & $4 / 8 / 76$ & 0.0002 \\
$699-34-42$ & $4 / 8 / 76$ & 5 \\
& $2 / 13 / 76$ & 5 \\
$699-35-70$ & $4 / 8 / 76$ & 37.0 \\
$699-35-9$ & $4 / 8 / 76$ & 0.8 \\
$699-49-57$ & $4 / 8 / 76$ & 0.2
\end{tabular}

for wells away from sources in the 200 Areas were similar to those observed during previous years. The maximum concentration of iodine-129 measured in the unconfined aquifer was $37 \mathrm{pCi} / \mathrm{L}$ in we11 699-35-70 next to the 200-West Area. During 1980, fewer wells were sampled and analyzed for iodine-129 than in 1979 (Eddy and Wilbur 1981). All of the reported concentrations were less than $1 \mathrm{pCi} / \mathrm{L}$.

Iodine-129 monitoring results also have been included in the routine monitoring reports published since 1980 . The 1 ist of monitoring reports containing iodine-129 monitoring results consists of Eddy and Wilbur (1980); Eddy, Cline and Prater (1982); Eddy, Prater and Rieger (1983); Prater et al. (1984); Cline, Rieger and Raymond (1985); Price (1986); PNL (1987); Jaquish and Mitchel1 (1988); and Jaquish and Bryce (1989, 1990).

The occurrence of iodine-129 in ground water was investigated as part of the Basalt Waste Isolation Project (BWIP) study of the suitability of basalts beneath the Hanford Site as a potential geologic repository for high-level nuclear waste. In the BWIP investigations, iodine-129 and other radionuclides 


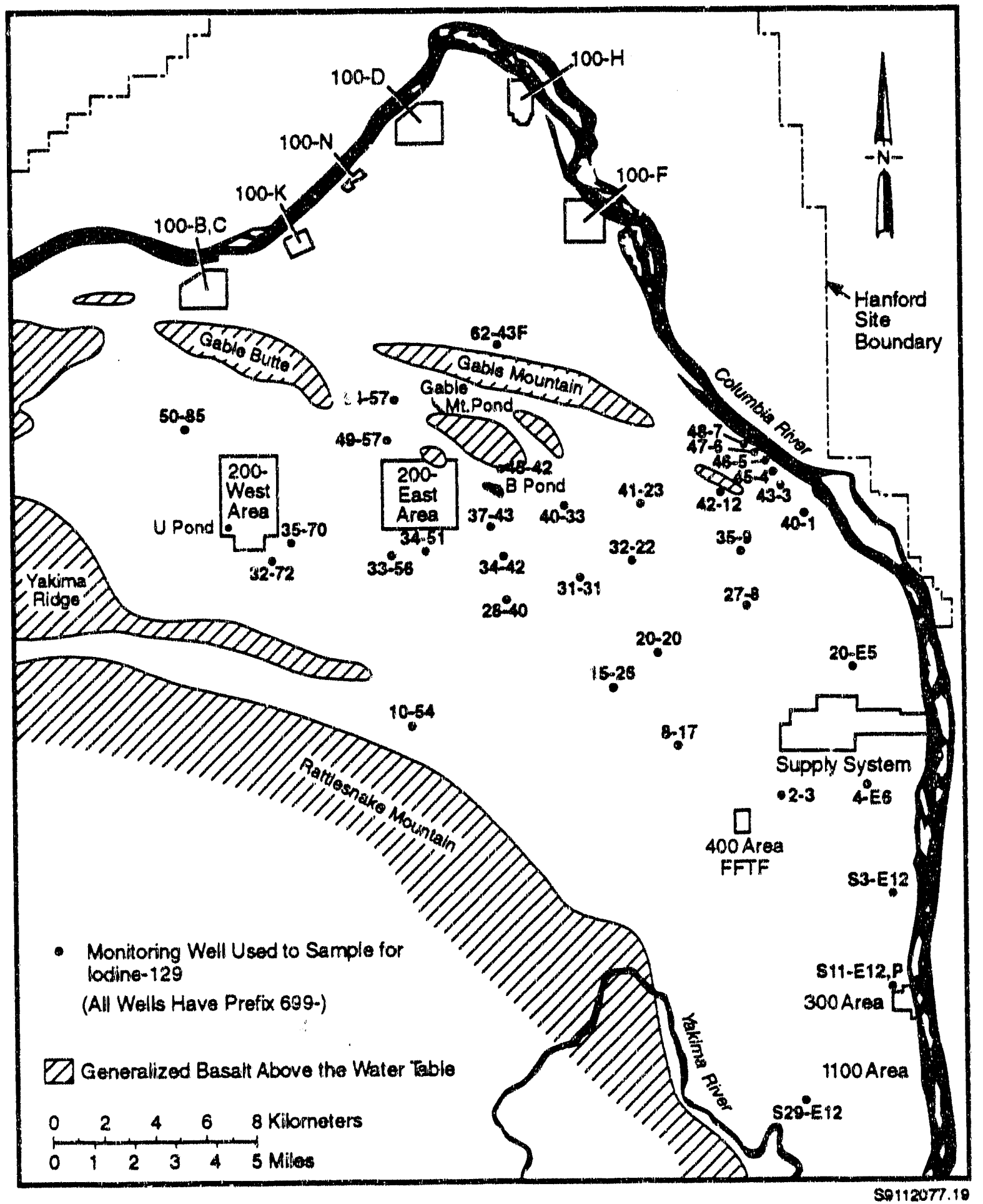

EJGURE 6.39. Distribution of Monitoring Wells Used to Sample for Iodine-129 During 1979 (after Eddy and Wilbur 1980) 
were considered potential tracers for examining ground-water movement beneath the Hanford Site (DOE 1988). The interest was in locating flow paths for rapid transport of radionuclides from the proposed repository to places where exposures could occur. The available iodine-129 data were considered to be "...insufficient to make any supported conclusions regarding large-scale ground-water movement beneath the Hanford Site or in the general area of the Umtanum Ridge-Gable Mountain anticline." The latter is a major geologic structural feature on the Hanford Site that resulted from folding of the basalt layers. However, the data were interpreted to support the potential for aquifer communication (transfer of water and/or contaminants between aquifers) along the anticline (DOE 1988).

Most of the iodine-129 data at the Hanford Site were collected as part of ground-water surveillance activities performed under the Site-wide groundwater monitoring program. Most of the data collected under these special programs were unpublished, although some of the data were included in the published quarterly reports. To correct this, DOE established an intercontractor working group (IWG) in November 1986 to assemble and review all previously unpublished data on iodine-129 in ground water at the Hanford Site. The findings are contained in the working group report (IWG 1987).

Four offsite water suppiy wells on the east side of the Columbia River and two former Army welis north of the Hanford Site (Figure 6.40) were sampled during the late 1960s and early 1970s to determine if contaminants were present. Nlost of these wells were open to more than one confined aquifer and, in some cases, to the unconfined aquifer. The main interest in the sampling program was to determine the concentrations of iodine-129 in ground water (IWG 1987). Because Hanford Site operations and offsite weapons testing introduced iodine-129 into the atmosphere, concentrations of iodine-129 in recentiy recharged ground water are significantly higher than concentrations found in "older" ground water. Natural background concentrations of iodine-129 for ground water in the basalt aquifers range from $10^{-8}$ to $10^{-9} \mathrm{pCi} / \mathrm{L}$, while the results of the offsite well sampling indicated that some iodine-129 was present in the wells at measured concentrations ranging from $10^{-6}$ to $10^{-4} \mathrm{pCi} / \mathrm{L}$ (IWG 1987). This comparison of concentrations indicated possible migration of 


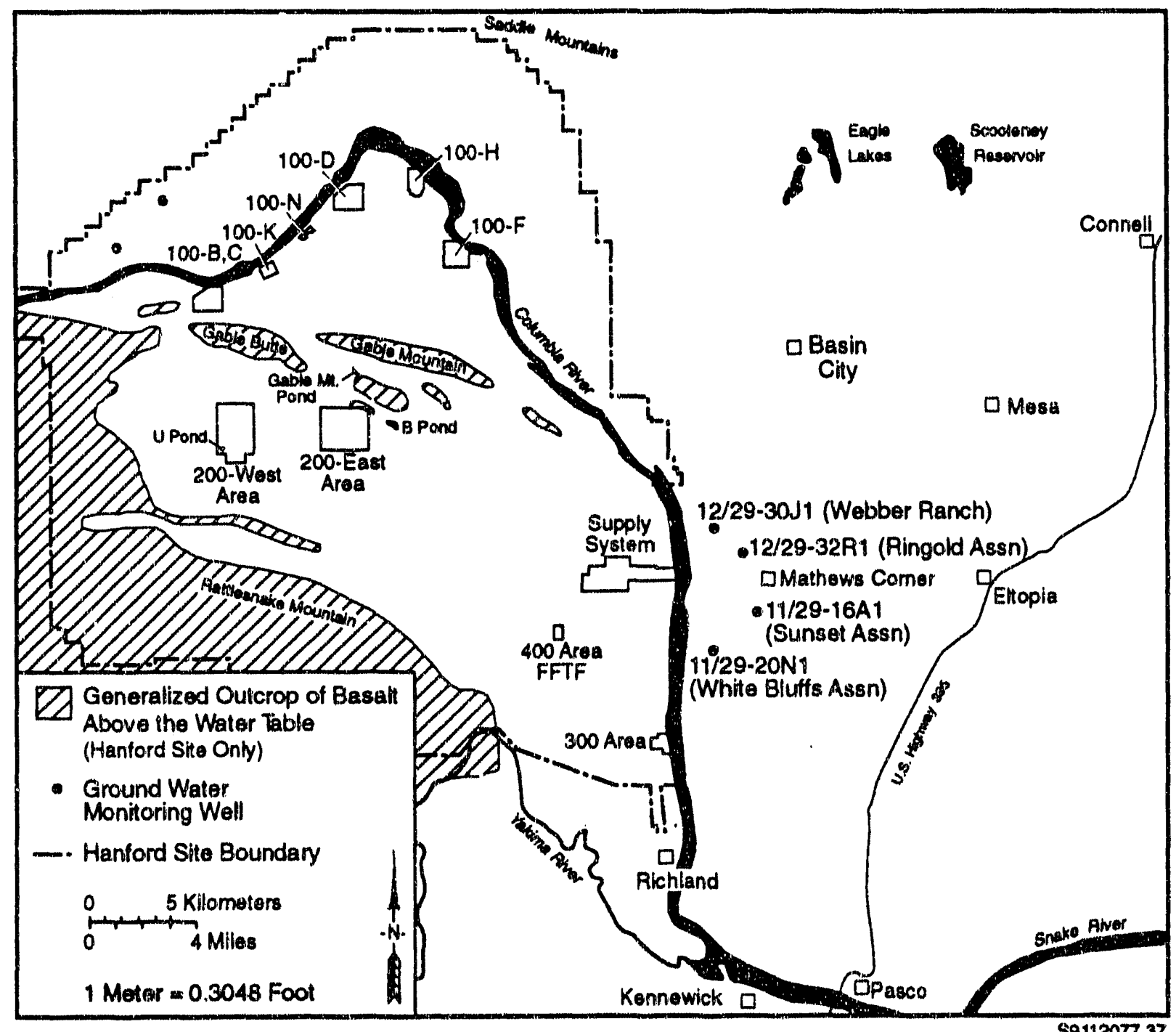

EIGURE 6.40. Location of Offsite Welis Sampled for Iodine-129 (after IWG 1987)

contaminated ground water off the Hanford Site. However, it was not conclusively determined whether the observed iodine-129 was from Hanford (IWG 1987).

The range of concentrations shown in Figure 6.41 is approximately the same as that currently found in surface water such as the Columbia River and in precipitation. A few samples collected during the early round of offsite sampling had concentrations between $10^{-4}$ and $10^{-3} \mathrm{pCi} / \mathrm{L}$. However, the early results were questionable because the sample-handling procedures were poor and 


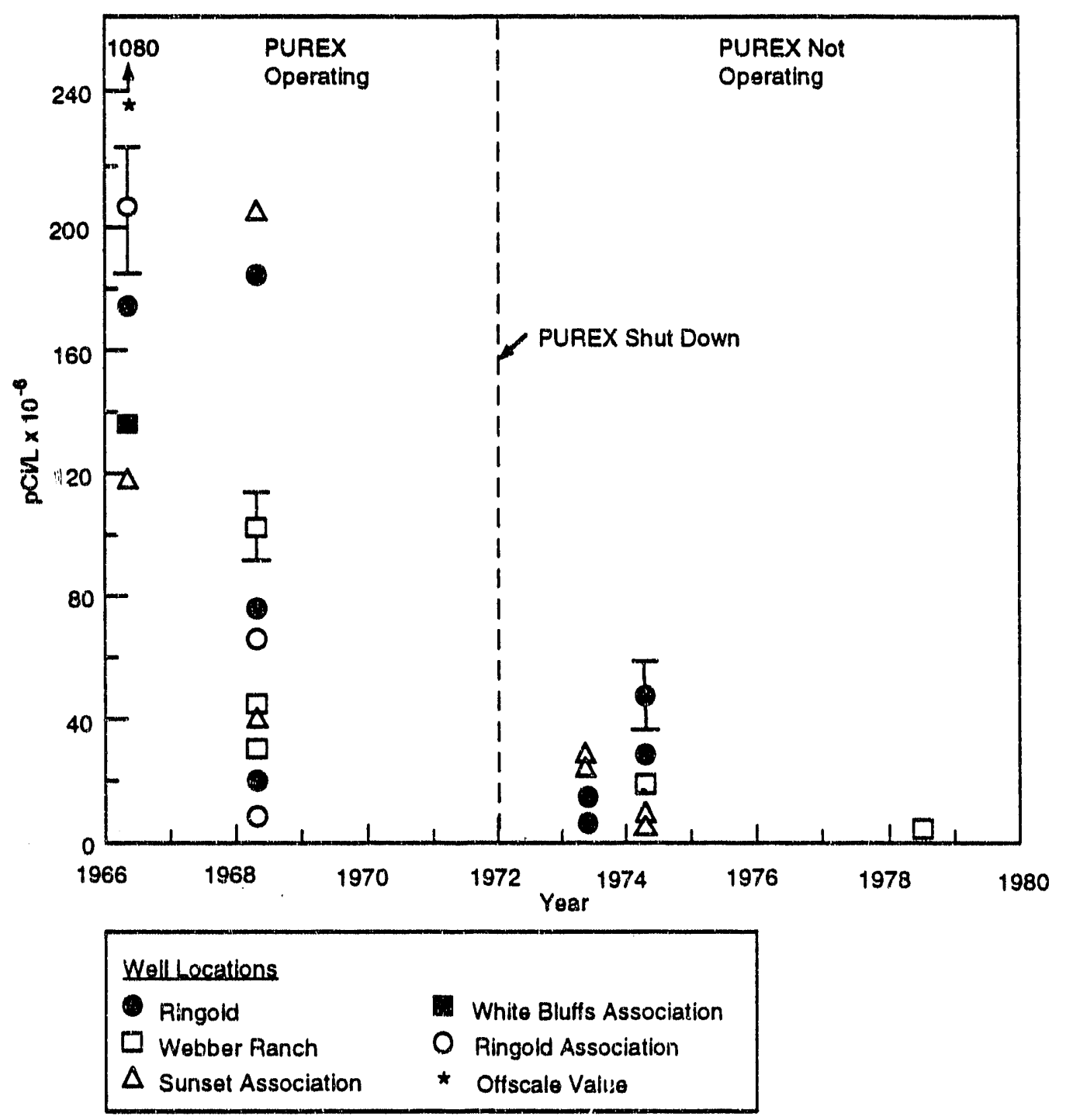

S9112088.7A

EIGURE 6.41. Iodine-129 Monitoring Results for Offsite Wells (after IWG 1987)

samples could be easily contaminated with iodine-129 during handling and analysis (IWG 1987). Sample-handling procedures improved during the following years, and later samples collected from the same wells showed lower concentrations of iodine-129. 
No conclusion has been reached regarding the source of iodine-129 in these offsite wells (IWG 1987; DOE 1988). Hydraulic heads in the confined aquifers indicate that ground water is not likely to flow across the Columbia River from the Hanford Site, especially with input of irrigation water on the east side of the river (Bryce et al. 1991). One possible explanation of the iodine-129 in the lower confined aquifers was that water from the unconfined aquifer flowed down unsealed well casings (IWG 1987). The unconfined aquifer east and north of the Hanford Site has been recharged with surface water from the Columbia Basin Irrigation Project. This water contains concentrations of iodine-129 that are higher than background, either from Hanford Site releases or offsite weapons testing.

Because of the presence of iodine-129 in offsite wells, 13 wells were drilled into the confined aquifer system on the Hanford Site during the mid1970 s as part of an offsite migration study funded by ARHCO and BWIP. As noted earlier, BWIP staff considered iodine-129 to be an ideal tracer that would assist them in determining the potential for offsite migration through the confined aquifers (IWG 1987). The wells were sampled annually for a few years for iodine-129; tritium; carbon-14; and oxygen-16,18, as well as for major and minor chemical constituents. The locations of these wells and results of analysis for iodine-129 are illustrated in Figure 6.42. Some of the iodine-129 sampling results for well DB-7 may have been affected by drilling practices which could have introduced iodine-129 into the sampled aquifer (IWG 1987).

Although the BWIP studies did not determine the source of the iodine-129 in the offsite wells, the measured concentrations ranged from $10^{-6}$ to $10^{-4}$ $\mathrm{pCi} / \mathrm{L}$. These concentrations resulted in doses between $2 \times 10^{-7}$ to $2 \times 10^{-5}$ $\mathrm{mrem} / \mathrm{y}$ effective dose equivalent $\left(7 \times 10^{-6}\right.$ and $7 \times 10^{-4} \mathrm{mrem} / \mathrm{y}$ dose to the thyroid). Therefore, iodine-129 in confined ground water did not result in significant radiation doses.

Other Radionuclides

Reporting of other radionuclides in Hanford Site ground water was sporadic. In general, interpretations of the distributions (maps) of 


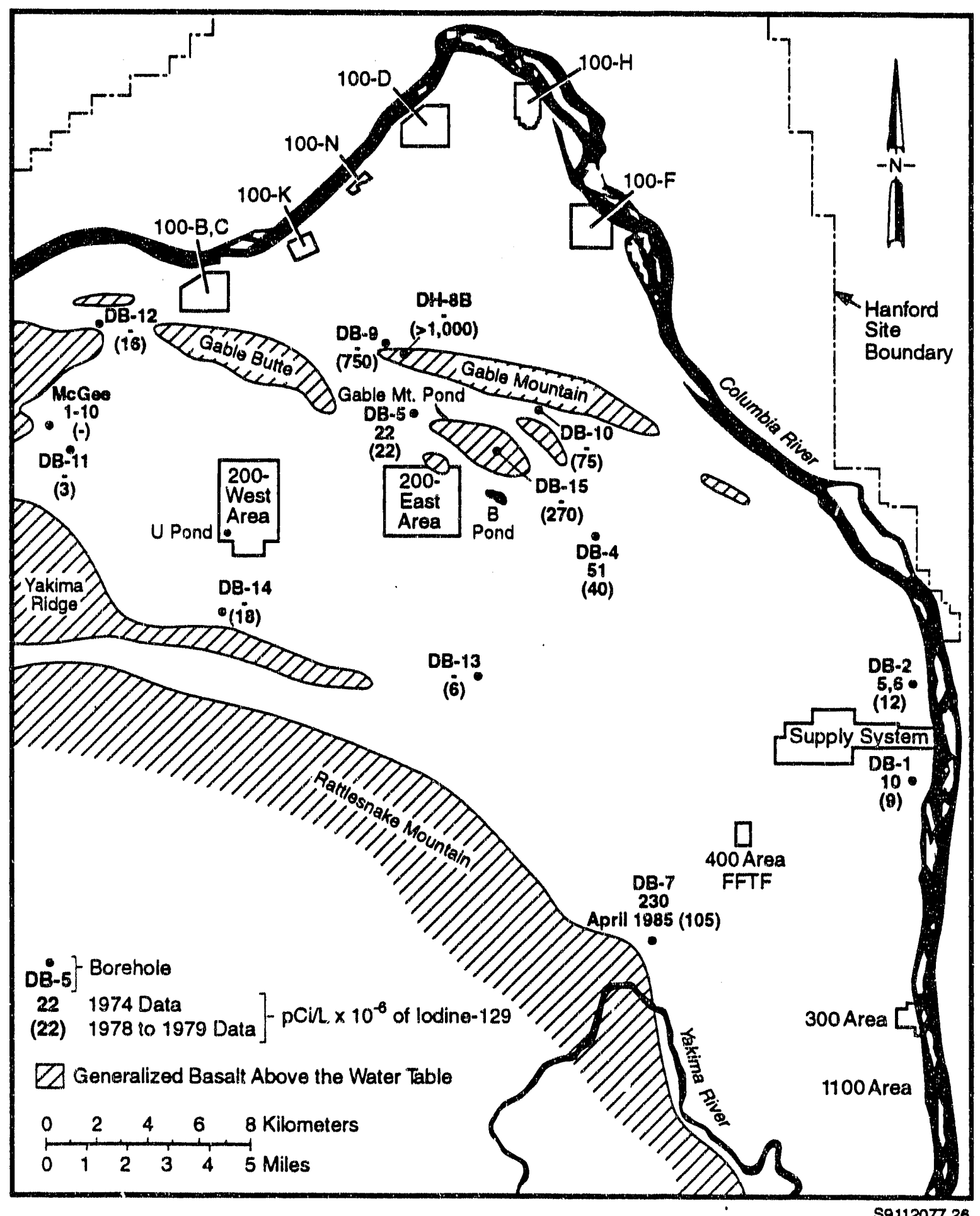

FIGURE 6.42. Comparison of Iodine-129 Concentrations in Wells in Confined Aquifers at the Hanford Site (after IWG 1987) 
radionuclides other than gross beta and tritium were not published. The reporting of radionuclides other than gross beta and tritium in the ground water increased with time. Evans et a1. (1990), Jaquish and Bryce (1990), and Woodruff et al. (1991) provided summaries of the distributions of various radionuclides.

As previously indicated (p. 6.33), cobalt-60 contributed to gross beta concentrations measured during early monitoring at the site. However, because of radioactive decay during 1989 and 1990, most cobalt-60 concentrations in the unconfined aquifer were consistently near or below the detection limit of $20 \mathrm{pCi} / \mathrm{L}$, except in the 100-N Area and near isolated portions of the 200-East Area (Jaquish and Bryce 1989; Woodruff et a1. 1991). The highest concentration of cobalt-60 in ground water (532 pCi/L) at the Hanford Site during 1989 was in well 699-50-53, directly north of the 200-East Area. This migration of cobalt- 60 is attributed to the presence of a complexing agent (another chemical) converting the cobalt-60 to a form that is mobile. This contamination is associated with cribs in the northern half of the 200-East Area where the flow direction is to the north through Gable Gap.

Strontium-90 is present in ground water near sources of 1iquid-waste discharge in the 200-East Area (Jaquish and Bryce 1990). Concentrations ranging up to $5740 \mathrm{pCi} / \mathrm{L}$ were present near the 216-B-5 reverse we11, which was in operation from 1945 to 1947 (Stenner et al. 1988), and up to $301 \mathrm{pCi} / \mathrm{L}$ in well 699-53-48 near Gable Mountain Pond. Strontium-90 is not very mobile in soil and ground water at the Hanford Site and ris remained near the sources of discharge. Except for possibly the 100-N Alea, strontium-90 did not contribute significantly to dose because it did not migrate offsite.

The highest concentration of technetium-99 in ground water at the Hanford Site was 41,000 pCi/L measured in well 299-W19-24 (Jaquish and Bryce 1990), downgradient of the inactive 216-U-1 and U-2 cribs in the 200-West Area. Technetium-99 is not attenuated in soil at the Hanford site and moves with the ground water. Contamination associated with these cribs is the combined result of past waste discharges and recent (1985) discharges to another nearby facility (Delegard et a1. 1986; Baker et a1. 1988). 
Cesium-137 in ground water at the Hanford Site is associated with discharges to the 216-B-5 reverse well (Jaquish and Bryce 1990). Concentrations measured during 1989 were $844 \mathrm{pCi} / \mathrm{L}$ in well 299-E28-23, $1070 \mathrm{pCi} / \mathrm{L}$ in well 299-E28-25, and $33 \mathrm{pCi} / \mathrm{L}$ in we11 299-E28-24 in the 200-East Area. As with strontium-90, cesium-137 is generally not mobile in soil and ground water at the Hanford Site. Therefore, cesium-137 did not migrate off site or contribute significantly to dose.

Plutonfum-239 is present in ground water near the 216-B-5 reverse well (Jaquish and Bryce 1990; Woodruff et al. 1991). Plutonium also binds strongly with sediments that make up the aquifers and thus has limited mobility in ground water at the Hanford Site. During 1989, concentrations of plutonium239 were $7.2 \mathrm{pCi} / \mathrm{L}$ in well 299-E28-23 and $72 \mathrm{pCi} / \mathrm{L}$ in wells 299-E28-25 and 299-E28-24. Plutonium-239 has not migrated away from the 216-B-5 reverse well and therefore did not contribute to offsite radiation dose.

Uranium is present in 200-West Area ground water near the 216-U-1 and U-2 cribs. (Jaquish and Bryce 1990). Concentrations of uranium in monitoring wells near this inactive facility were $85,000 \mathrm{pCi} / \mathrm{L}$ in 1985 (Delegard et a1. 1986; Baker et a1. 1988). The uranium, which is normally not considered to be mobile in soil and ground water at the Hanford Site, became mobile by complexing (chemically combining) with carbonate. Remediation in the form of ground-water pumping and uranium removal by anion exchange (Baker et a1. 1988) decreased the concentrations to near $2000 \mathrm{pCi} / \mathrm{L}$ during 1989 (Jaquish and Bryce 1990).

\subsubsection{Radionuclide Movement from the 100 Areas}

Both the discharge of effluent associated with reactor operations and the migration of contaminants from the 200 Areas have contributed radionuclides to the ground water beneath the 100 Areas. The primary radionuclides in the ground water from wastes associated with reactor operations are tritium, ruthenium-106, technetium-99, strontium-90, and cobalt-60 (Jaquish and Bryce 1990).

Early monitoring data for radionuclides in the 100 Areas are relatively sparse; however, the quantity of data increased with time. Published 
interpretations of distributions of radionuclides in the 100 Areas are limited. However, the flow paths for radionuclides from the 100 Areas to discharge into the Columbia River are relatively short, compared with flow paths from the 200 Areas. For example, Nelson (1964) estimated that $N$-Reactor coolant discharges to a crib in the 100-N Area would require 60 to 120 days to reach the Columbia River (less than $1 / 2$ mile away). This analys is was performed with conductance paper electric analogs (digital computers were not widely used at the time).

Gamertsfelder (1946e) reported that active springs along the river banks near the 100-D and 100-F Areas had maximum levels of gross beta emitters of $2.4 \times 10^{-4}$ and $1.7 \times 10^{-4} \mu \mathrm{Ci} / \mathrm{L}(240$ and $170 \mathrm{pCi} / \mathrm{L})$, respectively. These springs were probably the result of ground-water and contaminant seepage from the retention basins near these operating reactors. According to Gamertsfelder (1946e), the concentration reported at the 100-F Area spring during February 1946 was four times higher during the previous month. Although the retention basins for the reactor areas have been deactivated for some time, high concentrations from ground-water flow are observed in springs along the river bank (McCormack and Carlile 1985). During the 1970s, gross beta emitters were detected in ground water in the 100-N Area (Kipp 1972 , 1973a, 1973b, 1975).

More recently (1989), cobalt-60 was found in the ground water near the 1325-N liquid-waste disposal facility in the 100-N Area in concentrations near $100 \mathrm{pCi} / \mathrm{L}$ (Jaquish and Bryce 1990). Antimony-125 in concentrations of up to $94 \mathrm{pC} / \mathrm{L}$ was observed in ground water in the 100-N Area. In addition, during 1989, strontium-90 colicentrations of up to $23,400 \mathrm{pCi} / \mathrm{L}$ were observed in the 100-N Area. Although these concentrations are high, the ground water in the 100-N Area is not used for drinking and discharges directly to the Columbia River. Woodruff et a1. (1991) reported that during 1990, approximately $2 \mathrm{Ci}$ of strontium-90 were discharged to the river. However, this discharge was not measurable by comparing upstream and downstream concentrations of strontium-90 in the Columbia River during 1989 (Jaquish and Bryce 1990) and 1990 (Woodruff et a1. 1991). As described in Section 6.3, impacts to the Columbia River 
(determined by comparing upstream and downstream river concentrations of strontium-90 and other radionuclides) are small and are within the errors of measurement.

\subsubsection{Radionuclide Movement from the 300 Area}

Fuel fabrication wastes discharged to the ground are the source of radionuclides in the ground water beneath the 300 Area. The primary radionuclide in ground water from operation of the 300 Area is uranium, but chromium-51, cobalt-60, and ruthenium-106 have also been detected (Kipp 1973a). These radionuclides were attributed to disposal of low-level fuel processing wastes to two process ponds located in the northern portion of the 300 Area (Kipp $1973 a, 1973 b)$.

Early ground-water monitoring efforts in the 300 Area were directed toward detection of radionuclides (gross alpha and gross beta emitters) in the wells used to supply sanitary (drinking) water for the area. Parker (1945) included a statement that during 1945 no pollution of well water by radioactive wastes was evident. Alpha contamination observed in the 300 Area was attributed to the presence of natural uranium.

Parker and Gamertsfelder (1945b) reported that during the week ending June 30,1945 , alpha contamination near the detection limit was observed in a well in the 300 Area. The radionuclide was identified as uranium. Concentrations in the well decreased by the end of July 1945. Detectable concentrations of gross beta emitters were observed in wells in the 300 Area (Gamertsfelder 1946a-j; Parker 1946a-c, 1947a-c).

During the 1940s, uranium contamination continued to be detected in wells in the 300 Area and in Richland. Until July 1948, uranium concentrations in the 300-Area wells ranged from 8 to 29 micrograms per 1 iter $(\mu \mathrm{g} / \mathrm{L})$ and were considered to be indicative of natural uranium in the ground water (Healy 1948). During 1948, concentrations of uranium in the 300 Area increased dramatically. Healy (1948) reported that during July 1948, the maximum uranium concentration in the 300 Area was $234 \mu \mathrm{g} / \mathrm{L}$, and the average uranium concentration for the same month was $103 \mu \mathrm{g} / \mathrm{L}$. Elevated concentrations continued through the remainder of 1948; however, the reason for this increase 
was not known at the time. The use of wells in the 300 Area as a supply for drinking water was discontinued during December 1948 because of consistentiy detectable concentrations of uranium (30 to $65 \mu \mathrm{g} / \mathrm{L}$ during 0 ctober). The wells remained on the sampling and analysis schedule as test wells.

During 1949 and 1950, uranium concentrations continued to be above the detection limit in the 300 Area (Singlevich and Paas 1949b; Paas and Singlevich 1950a-d; Paas 1951a). Uranium concentrations were reported as $\mu \mathrm{Ci} / \mathrm{L}$, rather than the $\mu \mathrm{g} / \mathrm{L}$ units previously used. During 1951 , the concentration of uranium in one well in the 300 Area increased to a maximum of $1400 \mu \mathrm{Ci} / \mathrm{L}\left(1.4 \times 10^{9} \mathrm{pCi} / \mathrm{L}\right)$ with an average of $633 \mu \mathrm{Ci} / \mathrm{L}\left(6.3 \times 10^{8} \mathrm{pCi} / \mathrm{L}\right)$ (Paas 1951b, 1951c; Paas 1952a). The well is located in the northern portion of the 300 Area, and the contamination was attributed to discharges to process ponds.

During 1972, relatively high concentrations of gross beta emitters were reported for one well in the 300 Area (wel1 399-3-8) and were attributed to leakage of waste solutions from a line (that was repaired) to the 340 Laboratory waste-handling facilities.

The distribution of uranium beneath the 300 Area was interpreted for the first time in a monitoring report for 1986 (PNL 1987). The distribution of uranium in the 300 Area during 1987 is illustrated in Figure 6.43. Subsequent monitoring reports indicated that the distribution of uranium in the aquifer in the 300 Area was similar to that observed during previous years (Jaquish and Mitchel1 1988; Jaquish and Bryce 1989, 1990).

\subsection{RIVER CONCENTRATIONS RESULTING FROM GROUND-WATER DISCHARGE}

Radionuclide (tritium) concentrations in the river from ground-water discharge to the river during 1989 were estimated and compared with past estimates and results of river monitoring (Section 6.3). The calculation was made for the location where the tritium plume from the 200-East Area enters the river near the Hanford townsite. Concentrations were calculated at some point downstream where the plume in the river is assumed to be completely mixed. 


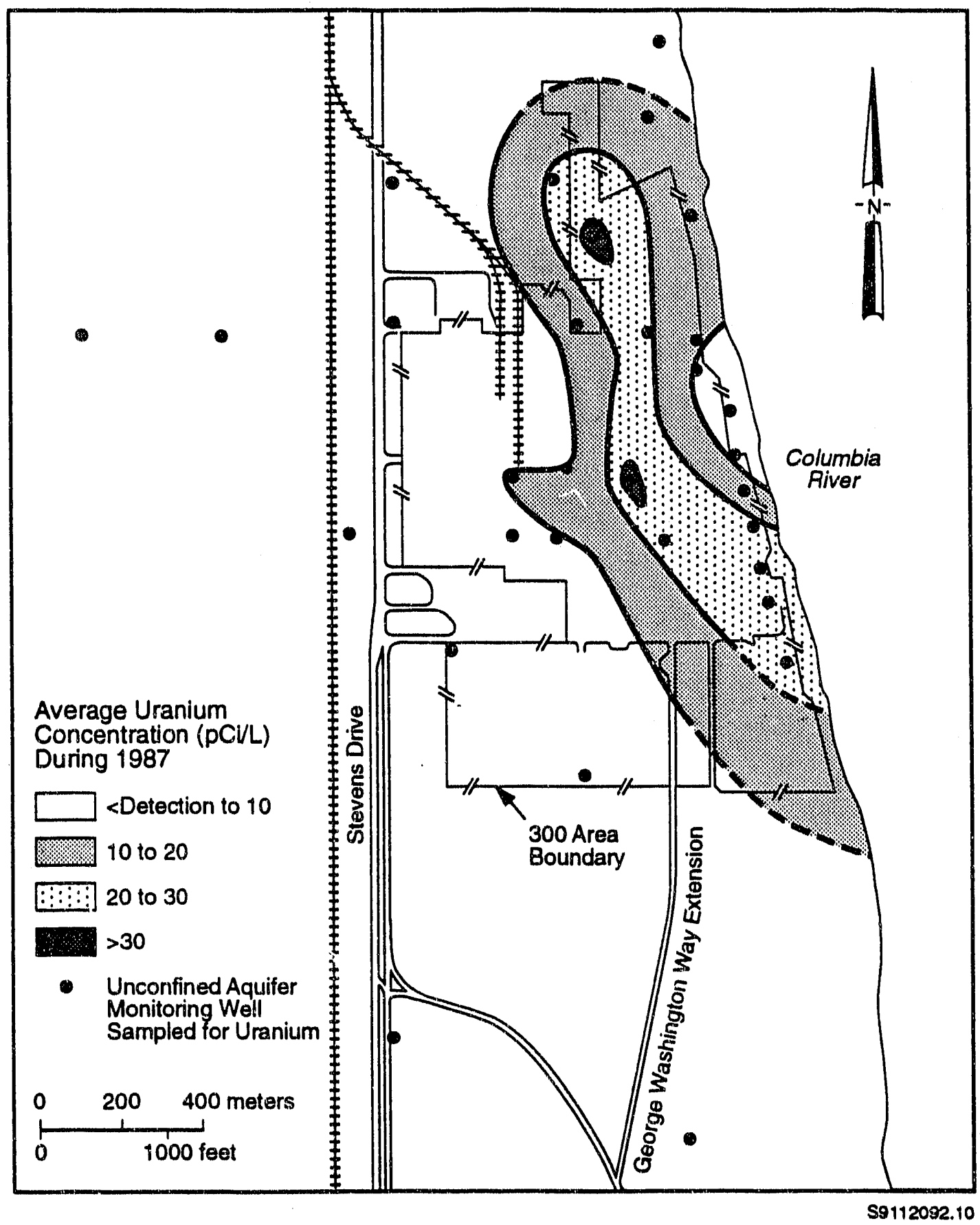

EIGURE 6,43. Distribution of Uranium in Ground Water Beneath the 300 Area During 1987 (Jaquish and Mitchell 1988) 
The calculation to estimate river concentration resulting from discharge of ground-water contamination originating in the 200 Area was performed for 1989 because that is the last year for which the ground-water monitoring results (Jaquish and Bryce 1990) were published. Woodruff et al. (1991) provided a summary of monitoring results for 1990, but the data listings have not been published.

The approach used for the simple estimate of radionuclide (tritium) concentrations in the river from ground-water discharge near the Hanford townsite was the same as that used by Prater et al. (1984):

$$
C_{\text {river }}=C_{\text {well }}\left(Q_{\text {gw }} / Q_{\text {river }}\right)
$$

where $C_{\text {river }}=$ the resulting radionuclide concentration in the $\operatorname{river}(\mathrm{pC} i / L)$

$C_{w e 11}=$ the average radionuclide (or maximum and minimum) concentration in the ground water $(\mathrm{pC} i / L)$

$Q_{g w}=$ the average ground-water discharge to the Columbia River in cubic feet per second (cfs)

$Q_{\text {river }}=$ the average (or maximum and minimum) flow rate of the river (cfs).

An average ground-water discharge to the Columbia River of 3 cfs was assumed for a 5-mile length of the river near the Hanford townsite. This estimate of ground-water discharge to the river was based on a model by Kipp et a1. (1976) of ground-water flow in the unconfined aquifer. The average flow rate of the Columbia River at Priest Rapids Dam during 1989 was 99,400 cfs, with a maximum monthly flow of 158,000 cfs and a minimum monthiy flow of 67,000 cfs (Jaquish and Bryce 1990). The average concentration of tritium measured in wells next to the river near the Hanford townsite during 1989 was $195,000 \mathrm{pCi} / \mathrm{L}$, with a maximum of $242,000 \mathrm{pCi} / \mathrm{L}$ and a minimum of $66,900 \mathrm{pCi} / \mathrm{L}$ (Jaquish and Bryce 1990). Based on the average Columbia River flow rates and average ground-water concentrations, tritium concentrations in the river (at the point downstream where the plume in the river is completely mixed) from ground-water discharge at the Hanford townsite were estimated to be $6 \mathrm{pCi} / \mathrm{L}$. The minimum river flow rate $(67,000 \mathrm{cfs})$ was combined with the 
maximum observed ground-water concentration $(242,000 \mathrm{pCi} / \mathrm{i})$ to provide a maximum concentration of approximately $11 \mathrm{pC} i / \mathrm{L}$ in the river. A minimum concentration of $1 \mathrm{pCi} / \mathrm{L}$ in the river was estimated with the maximum river flow rate $(158,000 \mathrm{cfs})$ and the minimum ground-water concentration $(66,900 \mathrm{pC} / \mathrm{L})$. These numbers provide an estimate of the possible range of concentrations in the river resulting from ground-water discharge.

Compared with the calculated river concentrations, the average tritium concentrations measured in the Columbia River at Priest Rapids Dam and the Richland pumphouse during 1989 were $63 \pm 5$ and $129 \pm 18 \mathrm{pCi} / \mathrm{L}$, respectively (Jaquish and Bryce 1990). The difference between the average upstream and downstream river concenirations, determined by Jaquish and Bryce (1990) to be statistically significant, was $66 \mathrm{pCi} / \mathrm{L}$. Other contributions of tritium to the Columbia River along the Hanford shorel ine occur from ground-water discharges in the 100 Areas. The radionuclides in liquid effluents discharged to the Columbia River from the 100-N Area during 1990 were estimated by Woodruff et a7. (1991). Their estimate for tritium was $38 \mathrm{Ci}$, and the estimate for strontium-90 was approximately $2 \mathrm{Ci}$. The effluent estimates for 1989 were not published in Jaquish and Bryce (1990), so they were not included in the calculation described in this report. However, assuming the discharge was similar to that for 1990, the average contribution of tritium to the river from the 100-N Area resulted in less than $1 \mathrm{pCi} / \mathrm{L}$. This estimate does not improve the comparison between the calculation and the measured differerice between upstream and downstream concentrations in the Columbia River.

However, the assumptions affecting both the measured and calculated concentrations in the river are described below.

The first assumption for the ground-water discharge calculation was that the ground-water flow model used to estimate unconfined ground-water discharge to the Columbia River (Kipp et al. 1976) was properly calibrated and that the discharge was correct. Calibration of the model of ground-water flow in the unconfined aquifer was described in Cearlock, Kipp and Friedrichs (1975). The model was calibrated such that the predicted heads matched observed (measured) heads. Although this method is commonly used to calibrate ground-water flow models, it does not guarantee that the discharges are correct. 
A second assumption is that the ground-water discharge is based on the entire saturated thickness of the aquifer. This means that all of the flow in the unconfined aquifer across the 5-mile length of river near the Hanford townsite was assumed to discharge to the river; and the tritium contamination, which has been demonstrated to be in the upper 30 feet of the aquifer (Eddy, Myers and Raymond 1978), was assumed to mix with the entire ground-water discharge.

A third assumption was that the average flow of the Columbia River was used for the calculation. Variations of the Columbia River (which occur daily and even hourly) change both the ground-water and contaminant discharge; as river levels increase, both the ground-water discharge and radionuclide concentrations in wells next to the river decrease in response to influx of river water into the aquifer and rising ground-water levels. As river levels drop, ground-water discharge and radionuclide concentrations in wells next to the river increase in response to ground-water flow and radionuclide transport from inland areas. During 1989, the monthly average flow ranged from 67,000 of s to 158,100 cfs (Jaquish and Bryce 1990). The variations in weekly and daily flow rates were probably larger than this range.

Finally, the concentrations in the river were calculated for the Richiand pumphouse, the nearest downstream point at which drinking water is drawn from the Columbia River. At this point, the tritium concentrations were assumed to be mixed with the entire flow rate of the river. This assumption has not been tested; determining whether it is correct would require additional measurements of concentration across the river at Richland, which is beyond the scope of the HEDR Project.

Other estimates of ground-water discharge have been made at the Hanford Site. Based on the model of Kipp et al. (1976), Raymond et al. (1976) and $\mathrm{Cline}$, Rieger and Raymond (1985) report $100 \mathrm{cfs}$ as the average discharge of the unconfined aquifer to the Columbia River over the entire Hanford reach of the river (compared with the 3-cfs estimate for the 5-mile reach of river near the Hanford townsite).

Prater et a1. (1984) estimated tritium concentrations of approximately $4 \mathrm{PCi} / \mathrm{L}$ in the Columbia River resulting from ground-water discharge to the 
river near the Hanford townsite during 1983. Their estimate was based on a ratio of the ground-water discharge ( $3 \mathrm{cfs}$ ) to the flow rate of the river $(130,000 \mathrm{cfs})$ and an average tritium concentration of $173,000 \mathrm{pCi} / \mathrm{L}$ measured in the ground water. By comparison, the average tritium concentration actually measured in the unconfined aquifer near the Hanford townsite during 1983 was slightly lower, and the average flow rate of the Columbia River was higher (Prater et a1. 1984), resulting in the lower predicted river concentration.

The calculated concentration of tritium in the river from ground-water discharge does not agree with the difference in measured concentrations in the river at upstream and downstream locations. As described in this section, not all of the uncertainties associated with the calculations and with the measurements have been quantified. However, because they are higher than the calculated values, the measured data will be used to develop dose estimates for this pathway.

\subsection{RIVER BANK SPRING MONITORING}

Several different studies have been conducted recently to characterize and monitor river bank springs discharging radionuclides to the Columbia River along the boundary of the Hanford Site. McCormack and Carlile (1985) sumnarized initial investigation of the springs; Dirkes (1990) summarized further characterization data for the spring discharges.

Most of the springs are small, flow intermittently, and are influenced by bank storage. Bank storage occurs when river water flows into the river bank during periods of high river flow. The water is then slowly released back into the river when the river is low. Bank storage is common along the Columbia River boundary of the Hanford Site because operation of Priest Rapids and other dams upstream of the Hanford Site is highly variable on a daily and even an hourly basis (Jaquish and Bryce 1990).

The interface between the ground water and the Columbia River is complex (Dirkes 1990). Seepage above the river level in river bank springs is considered to be a fraction of the total amount of ground water entering the river along the Hanford shoreline. The exchange of contaminants between the 
ground water and river through submerged seepage (below the river) is not well understood. Quantifying this exchange, however, requires both characterization and analysis and is beyond the scope of the HEDR Project.

\subsubsection{Description of River Bank Spring Monitoring}

McCormack and Carlile (1985) visually inspected the Hanford shoreline to locate springs and record their physical characteristics. Based on that inspection, selected springs were sampled and analyzed for tritium and nitrate. Dirkes (1990) represents a follow-up to the McCormack and Carlile (1985) study. Springs previously identified by McCormack and Carlile (1985) were sampled and analyzed for gross alpha, beta, and gamma emitters, as well as for tritium, nitrate, and various chemicals. In addition to the springs along the Hanford shoreline, Dirkes (1990) sampled and analyzed springs along the Franklin County side of the Columbia River and analyzed the samples for radionuclides.

Within the 41 miles of tianford shoreline covered by the visual inspection, McCormack and Carlile obsarved and documented 115 springs. Samples were collected from 41 of those spring: and analyzed for tritium and nitrate. Samples were collected from 6 additional springs and analyzed for uranium and nitrate. Dirkes (1990) collected samples from 18 different springs.

\subsubsection{Summary of Results}

Tritium concentrations measured by McCormack and Carlile (1985) in springs along the Hanford shoreline ranged between 80 and $110,000 \mathrm{pCi} / \mathrm{L}$. The maximum tritium concentrations of $38,000 \mathrm{pCi} / \mathrm{L}$ and $110,000 \mathrm{pCi} / \mathrm{L}$ were measured at the 100-N Area and near the Hanford townsite, respectively. Uranium concentrations up co $19 \mathrm{pCi} / \mathrm{L}$ were measured in springs in the 300 Area.

During 1988, Dirkes (1990) measured gross beta, tritium, and strontium-90 in 100-Area springs and found concentrations that were above the applicable drinking-water standards. The maximum concentration of tritium measured in the 100-Area springs was $111,000 \mathrm{pCi} / \mathrm{L}$, and the maximum measured concentration of strontium-90 was $7000 \mathrm{pCi} / \mathrm{L}$. Tritium concentrations up to $155,000 \mathrm{pCi} / \mathrm{L}$ and technetium-99 up to $220 \mathrm{pCi} / \mathrm{L}$ were observed in springs near the Hanford townsite. 
Dirkes (1990) reported that samples from springs on the Franklin County side of the river showed uranium concentrations at levels above those measured in the Columbia River. Uranium-234, -235, and -238 also were found in concentrations higher than those observed in the river. However, the Washington Department of Social and Health Services (WDSHS) determined that the uranium observed in ground water in Franklin County was natural, rather than from the Hanford Site (WDSHS 1988). In addition, concentrations of strontium-90 near the detection level were measured in samples from two different irrigation return canals in Franklin County, although the uncertainties associated with these results were large with respect to the measurements themselves.

\subsection{COLUMBIA RIVER MONITORING}

The Columbia River is used as a source of drinking water at onsite facilities and at communities located downstream of the Hanford Site (Jaquish and Bryce 1990). The river near the Hanford Site has been used for a variety of recreational activities, including fishing, hunting, boating, water skiing, sailboarding, and swimming. Water from the Columbia River is also used to irrigate crops downstream of the Hanford Site.

The river has been monitored at a number of different locations since Hanford Site operations began. The scope of the river monitoring program was to determine the impacts of Hanford Site operations on the Columbia River and to measure concentrations of radionuclides in the river that may have reached public drinking-water systems downstream of the Site (Jaquish and Bryce 1990).

\subsubsection{Description of River Monitoring}

Samples of Columbia River water have historically been collected from various locations near the Hanford Site, including drinking-water supply systems for the cities of Richland, Pasco, and Kennewick. Since 1963, the city of Richland's pumphouse has been the first point at which river water is withdrawn for public drinking water. From the mid-1970s to the present, water samples were collected from Priest Rapids Dam, the Vernita Bridge, White Bluffs, at the intake for the 300-Area water supply, and at various other locations in the Hanford reach of the Columbia River between Priest Rapids Dam 
and McNary Dam. Water samples were collected from the river with composite sampling systems designed to collect a fixed volume of water at set intervals and combine them in one sample.

\subsubsection{Summary of Results}

In the annual environmental monitoring reports and in some of the groundwater monitoring reports before 1985, monitoring results for different radionuclides at locations upstream were compared with those for locations downstream of the Hanford Site. These comparisons have been made for tritium, uranium, strontium-90, and iodine-129 in the river. Concentrations of cobalt60; cesium-137; and plutonium-239,240 in the river were also measured at upstream and downstream locations and then compared. Concentrations of radionuclides in the Columbia River upstream of the Hanford Site are from residual weapons test fallout and natural radioactivity. The difference between upstream and downstream concentrations was assumed to be from Hanford Site operations.

Although the tritium plume in the unconfined aquifer from the 200-East Area reached the Columbia River in 1977 (Myers 1978; Freshley and Graham 1988), no difference between upstream and downstream concentrations was observed in the river until higher concentrations (greater than $100,000 \mathrm{pC} i / L$ ) reached the river. Beginning in 1986, the differences between monthly average tritium and iodine-129 concentrations ai locations upstream and downstream of the Hanford Site were reported to be statistically significant (PNL 1987). Because none of the single-pass reactors was operating at that time, the contribution of radionuclides to the downstream monitoring location at the Richland pumphouse was attributed to ground-water discharge at the 100-Area springs, from the 300 Area, and near the Hanford townsite where the contamination plume from the 200-East Area enters the river. The appearance of measurable concentracions of tritium in the river corresponds to arrival of higher concentrations of tritium $(200,000$ to $2,000,000 \mathrm{pCi} / \mathrm{L})$ from the 200-East Area at the river during 1985 (Price 1986).

The average monthly differences of tritium and iodine-129 measured at locations upstream and downstream of the Hanford Site continued to be statistically significant from 1987 through 1989 (Jaquish and Mitchell 1988; Jaquish 
and Bryce 1989, 1990). Differences between tritium and iodine-129 concentrations at upstream and downstream locations were also significant when compared annually (see Figures 6.44 and 6.45). Comparisons of uranium and strontium-90 concentrations at upstream and downstream locations were not statistically significant during this reporting period.

From 1986 through 1989 the differences between monitoring results upstream and downstream for tritium and iodine were measurable (Figures 6.44 and 6.45). However, during that time contributions to dose from all sources of radionuclides in the river, including ground-water discharges, were small.

In 1986, SEARCH collected water samples from the Columbia River to determine nitrate concentrations resulting from ground-water discharge near the Hanford townsite (Buske and Josephson 1986). They measured nitrate concentrations at partial transects (cross sections) in the river along an 852-foot reach of the river. Ground-water discharges were estimated for nitrate based on observed concentrations in springs located on the banks of the river and on

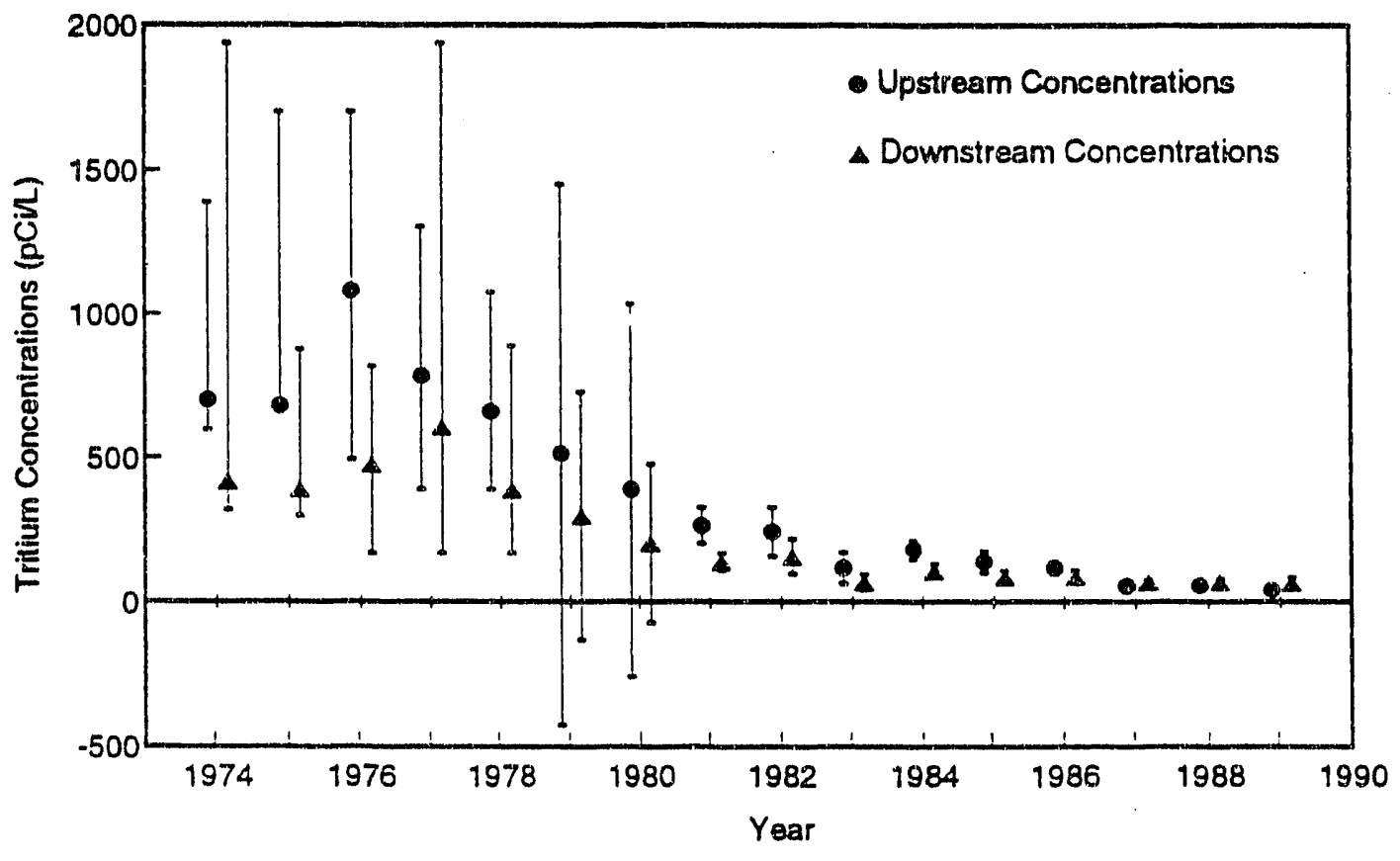

$\$ 9205068.30$

EIGURE 6.44. Average Annual Tritium Concentrations Measured in Columbia River Water at Upstream and Downstream Locations, from 1974 through 1989 


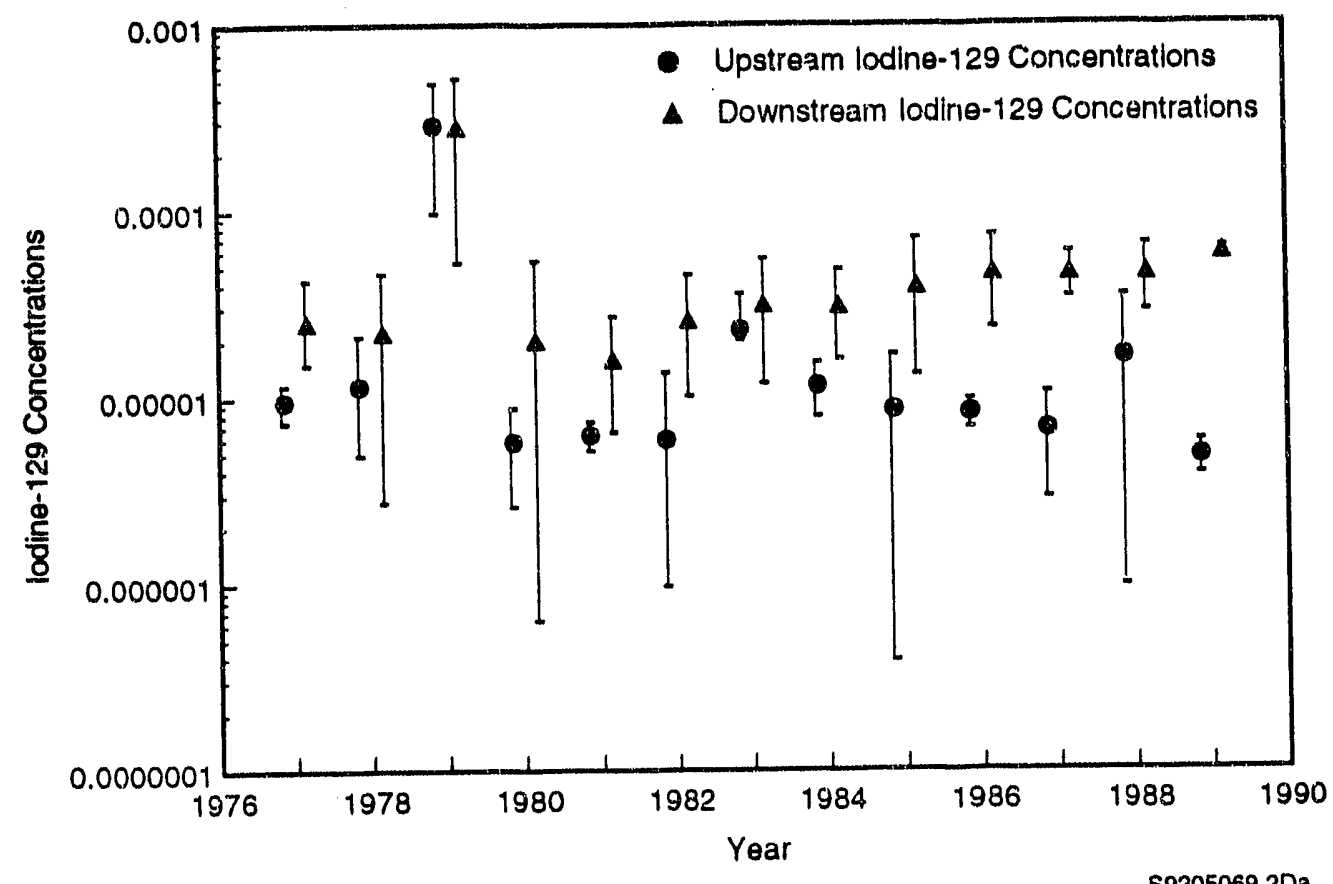

FIGURE 6.45. Average Annual Iodine-129 Concentrations Measured in Columbia River Water at Upstream and Downstream Locations, from 1977 through 1989

measured river velocities, depths, and nitrate concentrations. The USGS reviewed SEARCH's measurements and concluded that the results probably reflected release of bank storage water, rather than ground-water discharge from the unconfined aquifer (USGS 1987).

\subsection{GROUND WATER IN FRANKLIN COUNTY}

Concern has been raised regarding the potential for ground water on the Franklin County (east) side of the Columbia River to be contaminated with radionuclides of Hanford origin. A large-capacity well, such as an irrigation we11, might "pu11" contaminated ground water under the river through one or more confined aquifers. During pumping, the hydraulic head around the well could be lowered enough to cause water to flow toward the well from across the river.

To address this potential contamination, HEDR staff reviewed well records maintained by the state of Washington. The records show that approximately 
100 privately owned wells are open to the confined aquifers in the area east of the Columbia River and within approximately 12 miles of the Site boundary. Most of the wells are domestic wells for farms and houses. No large irrigation wells were identified. Irrigation wells are not common because, in most of the area, surface water is available for irrigation through the Columbia Basin Irrigation Project. A few of the domestic wells serve more than one household because the wells are deep and the cost of installation is relatively high. One relatively large domestic well is located about 3 miles east of the river near Ringold. Information collected during a well survey (Converse Ward Davis and Dixon Inc. 1981) indicated that this well was equipped with a 20- to 25-hp submersible pump; the depth to water was about 300 feet. With this configuration, the well can probably produce a few hundred gallons per minute. his well was sampled as part of the BWIP offsite investigations described in Section 6.1 (IWG 1987).

Work currently under way at PNL is designed to improve the characterization of ground-water flow in the upper confined aquifers to determine the potential for offsite migration of contaminants. As part of this effort, information from existing boreholes which penetrate the upper confined aquifers was compiled, and two new boreholes were drilled on opposite sides of the river near the Hanford townsite during 1990 and 1991. Current plans call for drilling additional boreholes and sampling over the next several years to determine if offsite migration of chemical and radiological contaminants through the confined aquifer system is occurring or is likely to occur in the near future.

\subsubsection{Effects of Irrigation}

Brown (1966) discussed the impacts to unconfined and confined aquifers within the Columbia Basin from irrigation in the Columbia Basin Irrigation Project, which began during 1950. In addition, he included observations of water-level changes resulting from Hanford operations and construction of Priest Rapids Dam and Wanapum Dam on the Columbia River upstream of the Hanford Site. The net resuit from operation of these facilities was to raise the water levels in the unconfined aquifers. Hydraulic heads in the uppermost confined aquifers beneath the Hanford Site also increased by recharge from the 
waste-water discharges where the upper confining basalt layer was eroded. On the north side of the Columbia River (north of the Hanford Site) in the Wahluke Slope area, the water levels in the unconfined aquifer rose in response to the Columbia Basin Irrigation Project operations to the east and to the Priest Rapids Dam pool to the west.

Large-scale artificial recharge still occurs from agricultural irrigation off the Hanford Site. Figure 4.10 illustrates water levels on both the Benton and Franklin County sides of the Columbia River and demonstrates the increased water-level elevations on the Franklin County (east) side of the river (Bryce et al. 1991). Because of the large hydraulic gradient toward the river (decrease of $150 \mathrm{M}$ over less than $5 \mathrm{~km}$ ), the unconfined aquifer on the Frankl in County side discharges to the Columbia River. As previously described in Section 4.6.1, recharge from irrigation in the Cold Creek Valley enters the Hanford Site as ground-water flow across the western boundary of the Site (Woodruff et al. 1991).

\subsubsection{Monitoring Results}

As previously described, elevated levels of uranium have been measured in a few domestic wells on the east side of the Columbia River (WDSHS 1988). Similarly, elevated concentrations of uranium have also been found in wells in other parts of eastern Washington, including the Okanogan Valley, southern Stevens County, and an area west of Spokane. The uranium in these areas was attributed to naturally occurring uranium minerals or to the use of fertilizers containing uranium (WDSHS 1988). However, the discovery of uranium in ground water near the Hanford Site prompted concern that contaminants might have moved across the Columbia River. A plume of uranium-contaminated ground water exists beneath the Hanford 300 Area (see Figure 6.43). This ground water is known to be entering the river in concentrations of about 20 to $30 \mathrm{pCi} / \mathrm{L}$ (Evans et al. 1990). The plume is located about 4 miles from the area where the water supply wells were found to contain elevated uranium concentrations.

The WDSHS conducted a follow-up study which included taking additional samples and analyzing them for tritium; cobalt-58,60; cesium-134,137; and strontium-90 (WDSHS 1988). None of these additional radionuclides was found. 
Therefore, the WDSHS concluded that water from the wells was in compliance with drinking-water standards, although no limit has yet been established for uranium. It was also determined that the affected wells were upgradient from the contamination in the 300 Area and, therefore, could not be impacted by the uranium plume in the 300 Area.

Water from one of the wells containing elevated concentrations of uranium was analyzed for three uranium isotopes: uranium-234, uranium-235, and uranium-238 (WDSHS 1988). Naturally occurring uranium contains about $0.7 \%$ uranium-235 with nearly all the remainder being uranium-238. However, most of the uranium in the 300-Area plume is enriched in uranium-235 because it originated from enriched reactor fuel. PNL also analyzed samples from the Franklin County we 11 and found that the water contained $0.65 \%$ uranium-235 by weight, which approximately matches the natural isotopic ratio and indicates that the uranium did not originate from the enriched uranium plume in the 300 Area.

Some uranium with a natural isotopic ratio was also disposed to the ground in the 300 Area during the earliest years of Hanford Site operations. This uranium affects ground water to the south of the more concentrated plume of enriched uranium (Evans et a1. 1990). The maximum concentration of uranium with the natural isotopic ratio found in some of the 300-Area wells is approximately the same or a little less than the concentrations found in the Franklin County water supply wells. Dispersion would be expected to dilute the concentration considerably if the uranium were moving offsite. So, even if there were an apparent hydraulic path to the water supply wells, it is unlikely that the concentrations of natural uranium found in the water supply wells could have a source in the 300 Area where concentrations are about the same. This was an additional reason that WDSHS presented for concluding that the 300-Area plume did not affect the water supply wells in Franklin County. Additional evidence is presented in Figure 4.11. As that figure shows, the hydraulic gradient in Franklin County is toward the river. This steep hydraulic gradient would prevent contamination from migrating to wells in Franklin County.

PNL collected and analyzed samples of well water from five offsite domestic wells in 1988 and four wells in 1989 (Jaquish and Bryce 1989, 1990). 
The wells are located in Frankl in County east of the Hanford Site (Figure 6.46). Samples were collected quarterly from the wells and analyzed for gross alpha, gross beta, tritium, iodine-129, and uranium-234,235,238. Elevated gross alpha and gross beta concentrations are attributed to elevated concentrations of natural uranium present in the area. The general levels of radionuclides, including iodine-129, were comparable with concentrations reported by WDSHS (1988) and were within the applicable drinking-water standards (EPA 1976) which apply to water from wells in Franklin County.

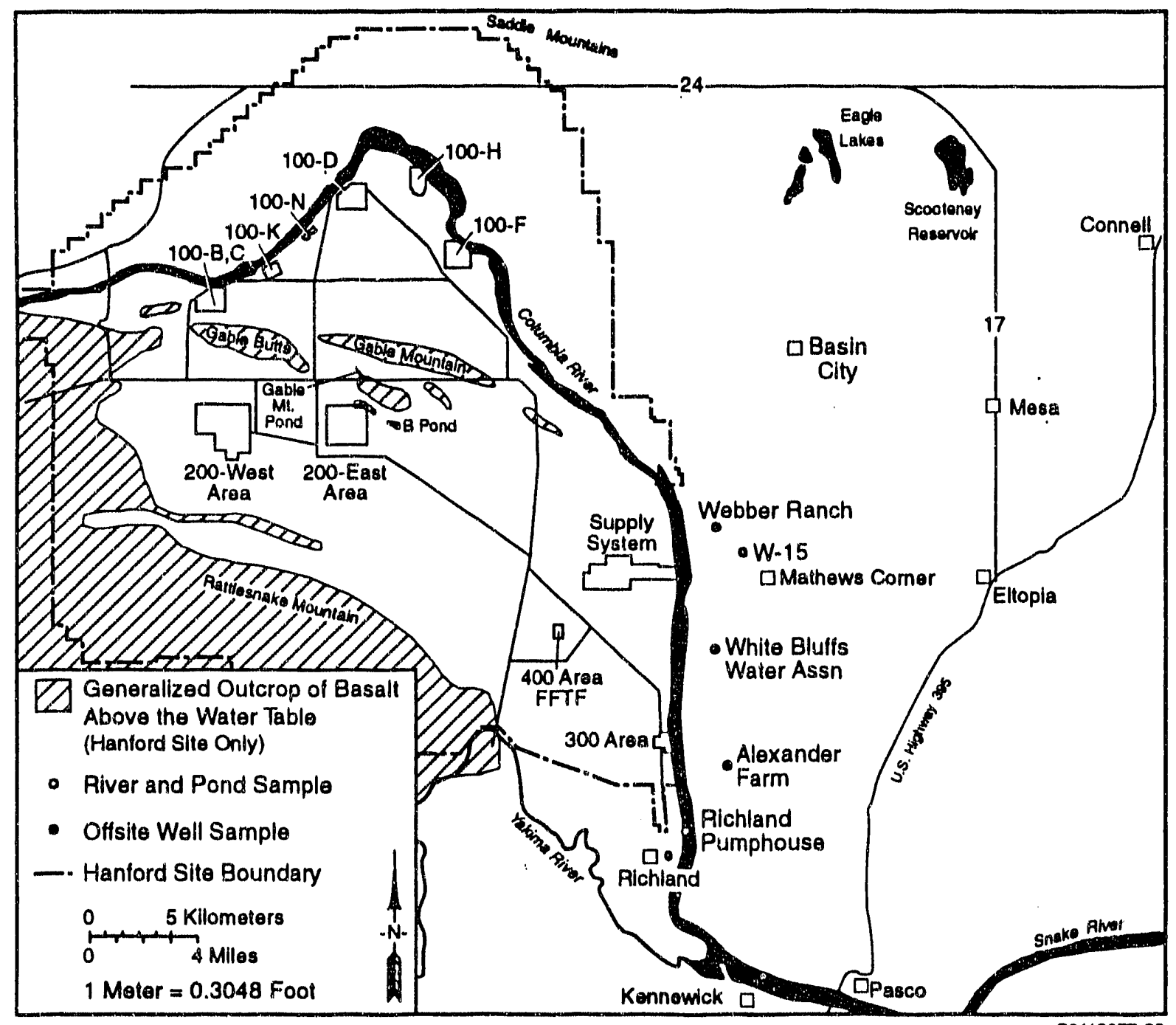

FIGURE 6.46. Offsite Well-Sampling Locations During 1988 and 1989 (after Jaquish and Bryce 1990) 


\subsection{RADIATION DOSES FROM OFFSITE MIGRATION}

Radiation doses from the offsite migration pathway were assessed by review of published dose estimates. The two primary ground-water pathways for which dose calculations have been published are from radionuclide discharge to the Columbia River (Woodruff et a1. 1991) and from consumption of ground water from wells in Frankl in County (WDSHS 1988).

70.71 Calculations of radiation dose were made based on the difference in average radionuclide concentrations measured in the Columbia River upstream and downstream of Hanford (Woodruff et a1. 1991). The differences between the upstream and downstream river concentrations (Figures 6.44 and 6.45) were large during 1990 compared with other years; this difference was attributed to seepage (discharge) of contaminated ground water from the Hanford Site. The effective dose equivalent attributable to the differences in the annual average concentrations of tritium, technetium-99, and iodine-129 in the river during 1989 was estimated to be $0.02 \mathrm{mrem} / \mathrm{y}$ effective dose equivalent. Approximately the same dose was reported for 1990 for the river pathway (Woodruff et al. 1991). The dose for 1990 was calculated only for tritium and iodine-129 because technetium-99 was not detected in the river. The doses were calculated for a hypothetical maximally exposed individual and included external exposures from river recreation, drinking water, consumption of foodstuffs contaminated by irrigation, and consumption of fish from the river. The calculation was based on the difference between the average concentrations at Richland and at Priest Rapids Dam during 1990.

The population affected by discharge of ground-water contamination to the Columbia River was primarily residents of Richland, Kennewick, and Pasco.

These communities accounted for up to $80 \%$ of the use of treated Columbia River water for drinking between Hanford and the river mouth. The 1990 population totals for the Tri-Cities area were Richland, 30,250; Kennewick, 37,910; and Pasco, 17,820 (Woodruff et al. 1991). The populations of these communities have varied over time, but most of the time, the totals are expected to be less than the 1990 data.

Because the contribution of radionuclides to the river from ground water was smaller during previous years, the doses estimated for 1989 and 1990 
represent the maximum. Thus, the average dose attributable to discharge of radionuclides in Hanford Site ground water to the Columbia River was small over the full study period.

Two radionuclides potentially contributed to radiation doses from drinking water from wells in Franklin County. First, the radiation doses for exposure to iodine-129 in drinking water from wells in Franklin County range from $2 \times 10^{-7}$ to $2 \times 10^{-5} \mathrm{mrem} / y$ effective dose equivalent $\left(7 \times 10^{-6}\right.$ to $7 \times 10^{-4}$ mrem/y dose to the thyroid). Compared with the TSP dose decision level of $100 \mathrm{mrem} / \mathrm{y}$ effective dose equivalent for an adult, these doses are negligible. (a) Second, results of the WDSHS investigation (WDSHS 1988) demonstrated that the uranium found in Franklin County wells was of natural origin and was not from the Hanford Site.

(a) Shleien, B. 1992. "Scoping Document for Determination of Temporal and Geographic Domains for the HEDR Project." Prepared for the Technical Steering Panel, approved by the TSP in April 1992. Washington State Department of Ecology, 1-800-545-5581. 



\subsection{HANFORD SITE DRINKING-WATER WELL PATHWAY}

The Hanford Site drinking-water well pathway consists of wells on and adjacent to the site that were used for water supply. A number of groundwater wells on the Hanford Site have been used to supply drinking water. Currently, ground-water wells are used to supply drinking water at remote locations such as the Hanford Patrol Training Academy and ihe PNL Observatory on Rattiesnake Mountain. A few wells near the Hanford Site are currently used to supply drinking water; the closest offsite location of drinking-water withdrawal is the backup well system for the city of Richland.

\subsection{DRINKING-WATER SYSTEMS ON AND ADJACENT TO THE HANFORD SITE}

Drinking water at the Hanford Site is obtained from both the Columbia River and ground water. Ground water has been used as a source of drinking water at a number of DOE facilities on the Hanford Site (Figure 7.1). The individual systems supplying this water generally consist of a raw water suppiy, treatment facilities, and distribution piping. The total number of systems has varied with time, but during 1989, 15 individual drinking-water systems were used (Thurman 1990). The current drinking-water systems at the Hanford Site, including those supplied by water from the Columbia River, are summarized in Appendix B. All of the systems were operated by DOE. contractors except for the city of Richland municipal system, which provides water to the areas in the southern portion of the Hanford Site and backup to the Columbia River supply. During 1989, ten of the systems used Columbia River water as a raw water source; four systems used ground water; and one system used a combination of the two.

During early operation of the Hanford Site, ground water was used as a drinking-water supply at a number of locations: the 300 Area, the Hanford townsite, Columbia Camp, Richland, the Pistol Range, and White Bluffs. The use of wells in the 300 Area as a supply for drinking water in the 300 Area was discontinued during December 1948 because of consistentiy detectable concentrations of uranium (30 to $65 \mu \mathrm{g} / \mathrm{L}$ during 0 ctober). The wells rentained 


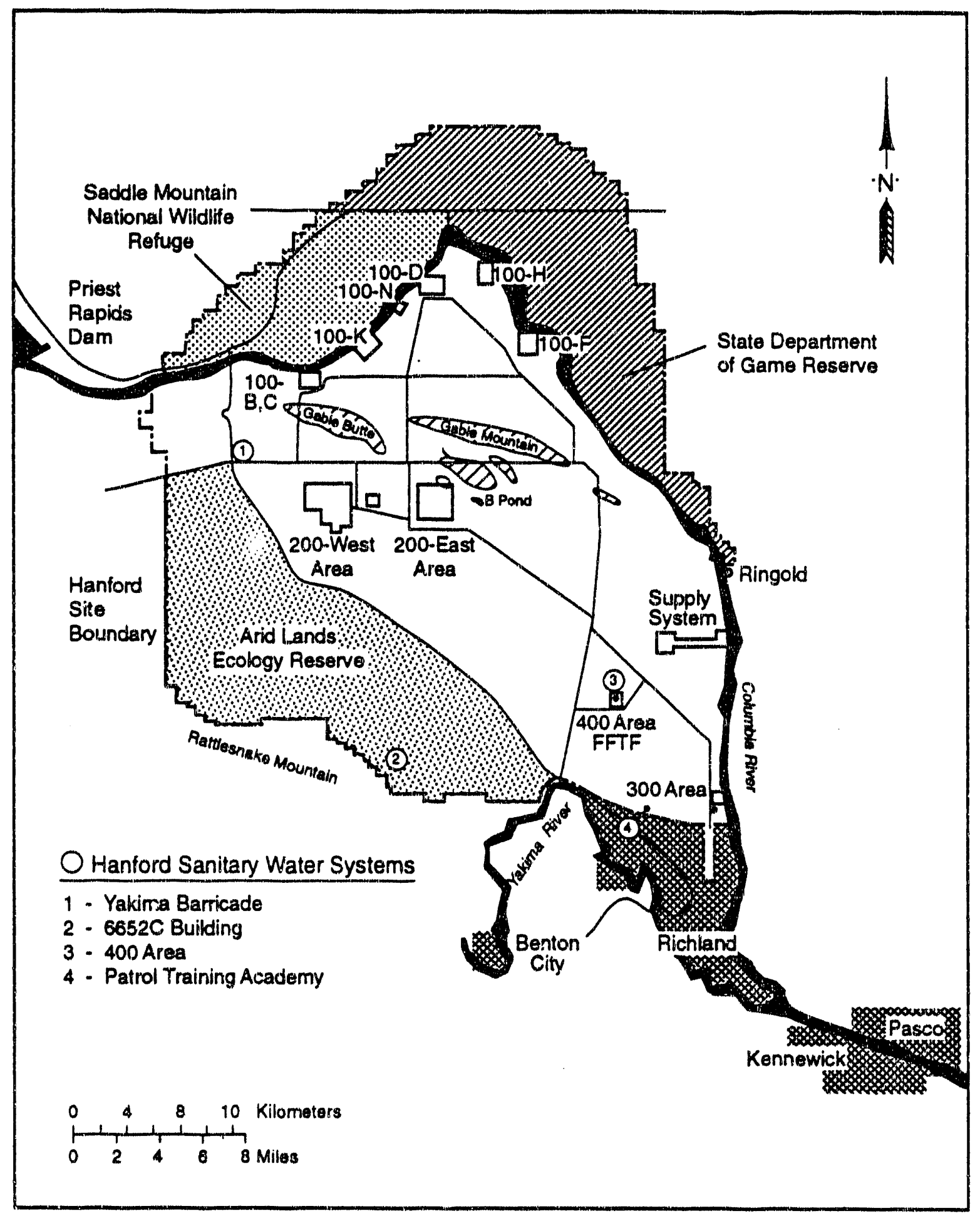

$\$ 9112077.32$

FIGURE 7.1. Locations of Water Systems Used to Provide Sanitary Water at the Hanford Site During 1987 (after Somers 1988) 
on the sampling and analys is schedule as test wells (Healy 1948) and were used as backup to the supply from the Columbia River until 1978 (Maas 1979).

Ground water was used as a source of drinking water for Richland until 1964, when withdrawals directly from the Columbia River replaced ground water as the primary source. Since 1964, ground-water wells in Richland have been used as backup for the river supply. Most of the Richland water supply wells are near unlined basins in North Richland which are recharged with water pumped from the Columbia River.

The drinking-water systems currently used at the Hanford Site range in size from those providing plant-scale treatment and serving extensive areas to eight systems that supply water to single or small facilities. Four systems using ground water as a raw water source serve single or small facility complexes. The facilities currently served by wells for drinking water include the FFTF in the 400 Area, the Yakima Barricade Guardhouse, the Hanford Patrol Training Academy, the PNL Observatory, and the 6652-I building on the Arid Lands Ecology (ALE) reserve (Somers 1988). Ground water was used instead of river water because these facilities are relatively distant from the river.

Before 1981, ground water was used for drinking at the Supply System's Nuclear Plant 2 (WNP-2), a non-DOE facility on the Hanford Site. The two wells that supplied the drinking water, 699-13-iA and 699-13-1B, are constructed in the upper portion of the unconfined aquifer. In 1980, a deeper (700+ foot) well (699-13-1C) was drilled and was used until 1981, when treated water from the Columbia River replaced ground water as a source of drinking water. Well 699-13-1C is now used only for emergency supply.

\subsection{SAMPLING AND ANALYSIS}

During the 1940s, ground-water monitoring efforts at the Hanford Site were directed toward detecting radionuclides (gross alpha and gross beta emitters) in the wells used to supply sanitary (drinking) water. Samples were collected and analyzed weekly (Parker 1945) from all drinking-water sources, including the Richland wells.

During recent years, all sources of drinking water at DOE facilities on the Hanford Site have been sampled at least once every 3 months and analyzed 
for water quality and radiological parameters to ensure compliance with applicable drinking-water regulations. These sources include both river water and ground water.

72.73 Surveillance of drinking water quality at the Site is shared by HEHF and PNL. PNL contributes to the radiological portion of the surveillance. Results of the drinking water quality surveillance are summarized in annual reports produced by HEHF and PNL (Somers 1988; Jaquish and Bryce 1990). Typically, samples are analyzed for gross alpha and gross beta radiation as well as for specific radionuclides. The list of radionuclides for which analyses were performed varied over time, but tritium, uranium, iodine-131, strontium-90, coba7t-60, zinc-65, and cesium-137 are included. Doses from the different radionuclides in drinking water at the Hanford Site are not included in the HEHF reports. Instead, the radionuclide concentrations are compared with appropriate EPA (EPA 1976) and Washington State drinking-water limits.

Raw water supplies (untreated) were sampled where multiple treatment facilities or extensive distribution systems were served by a single water source. These were mainly systems that used Columbia River water as the water source. In other cases with a single source and distribution system, the finished or treated water was sampled. Most of these single source and distribution systems were for ground-water wells. Samples were collected from wells primarily as monthly grab samples (Maas 1977; Thurman 1990). Several of the samples, notably at the 300-Area well and the 615 Building, were collected as weckly cumulative samples. The cumulative samples from these systems were based on automatic collection of 30 milliliters of water every 30 minutes to provide a weekly integrated sample.

Radiation dose equivalents (for a year of intake) resulting from exposure to radionuclides in drinking water on the Hanford Site were calculated each year and are summarized in the HEHF reports. The doses were calculated for occupational exposure based on a 40 -hour work week and a $220-\mathrm{L} / \mathrm{y}$ intake (Thurman 1990). Thus, impacts to occasional visitors to the FFTF would be far less tha the calculated doses to workers. In comparison, the EPA standard for normal exposure to drinking-water contamination is based on a 168-hour week residency and a $730-L / y$ intake. 


\subsection{MONITORING RESULTS}

Results of the early ground-water monitoring showed that concentrations were at or below the detection limits, which are suminarized in Section 5.2.3 (Parker 1945; Parker and Gamertsfelder 1945b; Gamertsfelder 1946a-j; Parker 1946a-d, 1947a, 1947b; Healy 1948). Wells in the 300 Area continued to have concentrations of radionuclides at and near the detection limit. Until July 1948, uranium concentrations in the 300-Area wells were considered to be indicative of natural uranium in the ground water. In mid-1948, concentrations of uranium in the 300 Area wells increased dramatically, as described in Section 6.1.3.

of the drinking-water systems that HEHF monitors at the Hanford Site, only two have shown detectable concentrations of radionuclides: uranium at the well providing backup drinking water to the 300 Area, and tritium and iodine-129 in the well supplying drinking water at the FFTF. In the 300 Area, observations of tritium and uranium during 1977 were 720 and $36 \mathrm{pCi} / \mathrm{L}$, respectively. The average uranium concentration during 1977 resulted in a dose of less than 0.1 mrem (Myers 1978). As noted previously, use of the 300-Area well as backup was discontinued in 1978.

The only drinking water from a ground-water source at the Hanford Site that is currently accessible to the public is at the FFTF Visitor Center. Potentially affected people would be visitors to the FFTF. The original wells supplying the drinking water for the FFTF were drilled in 1972 (McGhan, Mitchell and Argo 1985). An additional well, currently the main water supply well, was drilled in 1985 and first used in 1986 (Somers 1987).

Monitoring results for radionuclides in the FFTF's water supply are summarized in Table 7.1. The concentrations of tritium in the drinking-water supply at the FFTF over time are illustrated in Figure 7.2. The highest reported tritium concentration of $51,000 \mathrm{pCi} / \mathrm{L}$. during 1977 resulted in a calculated dose of $1 \mathrm{mrem} / \mathrm{y}$, based on the occupational exposure that is described in Section 7.2 of this report. Changes in the trend of concentrations over time result from stratification of contamination in the upper portion of the unconfined aquifer and from use of wells drilled to different 
TABLE 7.1. Summary of Monitoring Results for the Water Supply at the FFTF

Concentration (pCI/L)

\begin{tabular}{|c|c|c|c|c|c|c|}
\hline Year & Alpha & Beta & Tritium & Cobalt -60 & Zinc- 65 & Cesium-137 \\
\hline 1976 & 1.2 & $<8$ & $49,000 \pm 27,000$ & $\star(a)$ & * & * \\
\hline 1977 & 0.88 & 8.8 & $51,000 \pm 25,000$ & * & * & * \\
\hline 1978 & $0.96 \pm 0.93$ & $<7.1$ & $48,000 \pm 22,000$ & * & * & * \\
\hline 1979 & $0.54 \pm 0.37$ & $8.5 \pm 3.9$ & $27,000 \pm 19,000$ & $0.96 \pm 1.6$ & $0.45 \pm 3.7$ & $0.82 \pm 13.1$ \\
\hline 1980 & $0.72 \pm 0.91$ & $7.3 \pm 7.6$ & $35,000 \pm 20,000$ & $1.20 \pm 2.6$ & $0.11 \pm 4.8$ & $0.34 \pm 2.1$ \\
\hline 1981 & $1.1 \pm 0.31$ & $6.4 \pm 3.1$ & $39,854 \pm 5,537$ & $1.60 \pm 0.63$ & $0.26 \neq 0.3$ & $0.07+0.13$ \\
\hline 1982 & $0.50=0.81$ & $8.5 \pm 7.4$ & $18,000 \pm 6,500$ & $N R^{(b)}$ & NR & NR \\
\hline 1983 & $7.9 \pm 1.0$ & $5.1 \pm 6.6$ & $25,000 \pm 19,000$ & NR & NR & NR \\
\hline 1984 & $0.53 \pm 0.27$ & $9.0 \pm 4.8$ & $29,000 \pm 5,600$ & NR & NR & NR \\
\hline 1985 & $0.52 \pm 0.38$ & $10.0 \pm 2.51$ & $21,800 \pm 1,800$ & NR & NR & NR \\
\hline 1986 & $0.46 \pm 0.31$ & $7.7 \pm 2.2$ & $8,500 \pm 12,700$ & NR & NR & NR \\
\hline 1987 & $0.05 \pm 0.12$ & $7.2 \pm 2.2$ & $4,100 \pm 2,400$ & NR & NR & NR \\
\hline 1988 & $-0.02 \pm 0.29$ & $8.0 \pm 1.5$ & $7,290 \pm 2,980$ & NR & NR & NR \\
\hline 1989 & $0.12 \pm 0.10$ & $6.0 \pm 0.5$ & $8,280 \pm 1,080$ & NR & NR & NR \\
\hline
\end{tabular}

Concentration (DCI/L)

\begin{tabular}{|c|c|c|c|c|c|c|}
\hline \multirow[b]{2}{*}{ Year } & \multirow{2}{*}{ Strontium-90 } & \multirow{2}{*}{ Iodine-131 } & \multirow{2}{*}{ Radium-226 } & \multirow{2}{*}{ Radium-228 } & \multirow{2}{*}{ Technet fum-99 } & \multirow{2}{*}{ Ruthenium-106 } \\
\hline & & & & & & \\
\hline 1976 & $N R^{(b)}$ & NR & NR & NR & NR & NR \\
\hline 1977 & $\star$ & * & 0.15 & 0.46 & NR & NR \\
\hline 1978 & $<0.60$ & * & $<0.05$ & 0.35 & NR & NR \\
\hline 1979 & $0.06 \pm 0.11$ & $0.07 \pm 0.42$ & $0.05 \pm 0.06$ & $0.26 \pm 0.25$ & $0.47 \pm 6.6$ & $1.4 \pm 2.0$ \\
\hline 1980 & $0.04 \pm 0.34$ & $0.01 \pm 0.57$ & $0.05 \pm 0.08$ & $0.45 \pm 1.4$ & $7.5 \pm 5.2$ & $0.45 \pm 6.2$ \\
\hline 1981 & $0.08 \pm 0.07$ & NR & $0.06 \pm 0.02$ & $0.10 \pm 0.06$ & NR & $-0.78 \pm 1.8$ \\
\hline 1982 & $0.16 \pm 0.37$ & NR & NR & NR & NR & NR \\
\hline 1983 & NR & NR & NR & NR & NR & NR \\
\hline 1984 & $0.063 \pm 0.047$ & NR & NR & NR & NR & NR \\
\hline 1985 & $0.12 \pm 0.10$ & NR & NR & NR & NR & NR \\
\hline 1986 & $0.08 \pm 0.04$ & NR & NR & NR & NR & NR \\
\hline 1987 & $0.01 \pm 0.02$ & NR & NR & NR & NR & NR \\
\hline 1988 & $-0.0005 \pm 0.009$ & NR & NR & NR & NR & NR \\
\hline 1989 & $-0.008 \pm 0.005$ & NR & NR & NR & NR & NR \\
\hline
\end{tabular}

(a) Asterisk denotes a reported value that is less than the detection limit.

(b) NR denotes "not reported." 


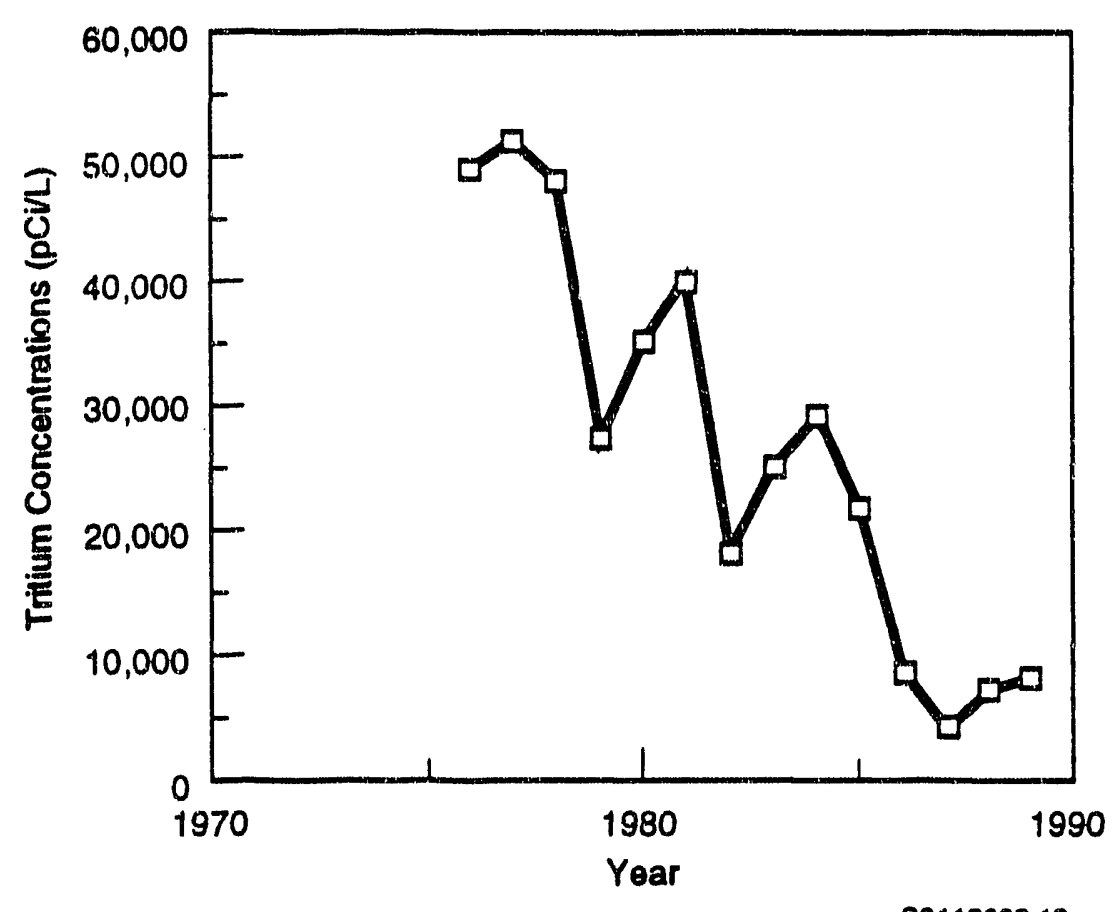

FIGURE 7.2. Concentration History of Tritium in Drinking Water at the FFTF

depths in the aquifer. As reported by Eddy, Myers and Raymond (1978), concentrations are higher near the top of the unconfined aquifer. 'After construction of the latest well at the FFTF in 1985, which is open to only the lower part of the unconfined aquifer, tritium concentrations in the water supply dropped to below $10,000 \mathrm{pCi} / \mathrm{L}$.

The concentrations of iodine-129 in the drinking-water supply at the FFTF over time are illustrated in Table 7.2. Before 1987, iodine-129 concentrations in the ground water at the FFTF were not reported. During 1989, one sample of FFTF drinking water was anaiyzed for iodine-129. The reported concentration of iodine-129 was $0.06 \mathrm{pCi} / \mathrm{L}$, well below $1.0 \mathrm{pCi} / \mathrm{L}$ level which would result in a dose of $4 \mathrm{mrem} / \mathrm{y}$ (Thurman 1990).

Myers, Fix and Raymond (1977) reported concentrations in wells supplying drinking water during construction of WNP-2. These concentrations are shown in Table 7.3. Based on ingestion of $1 \mathrm{~L} /$ day, $5 \mathrm{day} / \mathrm{wk}$, and $50 \mathrm{wk} / \mathrm{y}$, the annual dose from tritium in drinking water at the Supply System was calculated to be 4 mrem (Myers, Fix and Raymond 1977). This occupational consumption 
TABLE 7.2. Concentrations of Iodine-129 Reported in Drinking Water at the FFTF

\begin{tabular}{|c|c|}
\hline Year & $\begin{array}{c}\text { Iodine-129 } \\
\text { Concentration } \\
(\mathrm{pCi} / \mathrm{L}) \\
\end{array}$ \\
\hline 1987 & 0.01 \\
\hline 1988 & 0.005 \\
\hline 1989 & 0.06 \\
\hline
\end{tabular}

rate $(250 \mathrm{~L} / \mathrm{y})$ differs from the consumption rate used for dose calculations at the FFTF $(220 \mathrm{~L} / \mathrm{y})$. However, the doses vary linearly with consumption rates, so the doses can be scaled by the ratio of the consumption rates. The numbers reported here are the values originally reported in the references. However, as previousiy described, use of ground water to supply drinking water at the Supply System facility was discontinued in 1981.

Wells in the unconfined aquifer adjacent to the Hanford Site that could have been affected by radionuclides of Hanford origin are the water supply wells for the city of Richland (Bryce and Goodwin 1989). As described in Section 6.1.1, during the 1940 s and early 1950s, concentrations of gross beta emitters were intermittently measured in the Richland wells. However, the

IABLE 7.3. Radionuclide Concentrations in Drinking Water at the WNP-2 Construction Site During 1976 (from Myers, Fix and Raymond 1977)

\begin{tabular}{|c|c|c|c|c|c|}
\hline \multirow[b]{2}{*}{ Radionuclide } & \multirow{2}{*}{$\begin{array}{l}\text { Number of } \\
\text { Samples }\end{array}$} & \multirow{2}{*}{$\begin{array}{c}\text { Detection } \\
\text { Limit (DCi/L) }\end{array}$} & \multicolumn{3}{|c|}{ Concentration ( $\mathrm{pC} i / L)$} \\
\hline & & & Maximum & Minimum & Average \\
\hline Alpha & 3 & 0.3 & 4 & 3 & 4 \\
\hline Beta & 52 & 5 & 11 & (a) & $<6$ \\
\hline Tritium & 12 & 300 & 310,000 & 18,000 & 140,000 \\
\hline Cobalt-60 & 12 & 30 & (a) & (a) & (a) \\
\hline Cesium- 137 & 12 & 30 & (a) & (a) & (a) \\
\hline Radium-226 & 2 & 0.05 & 0.09 & 0.08 & 0.09 \\
\hline Radium-228 & 2 & 0.1 & 0.4 & 0.3 & 0.4 \\
\hline
\end{tabular}

(a) Less than detectable concentration. 
concentrations were always near the detection limits and were not attributable to radionuclides of Hanford origin. The wells, used to supply water for the city of Richland, were sampled routinely as part of the Hanford Site monitoring activities. The population affected would be individuals living in Richland.

After 1964, the Richland wells (Figure 7.3) were used only as backup to the primary system, which uses water withdrawn directly from the Columbia River, during periods of peak demand and when the primary water supply system is shut down for maintenance. The wells are recharged by basins (Figure 7.3), which receive water pumped from the river. Recently, five wells were drilled adjacent to the Richland well field to monitor the unconfined aquifer for contamination resulting from operations at maintenance facilities for the Hanford Site, which are immediately upgradient of the well field. Most of the concern for contamination was with chemical contaminants from spent battery acid, antifreeze, motor oils, solvents, degreasers, paints, and paint thinners. Water from these wells was also screened for possible radiological contaminants by sampling and analyzing for tritium. For all of the wells sampled, the analytical results were less than the $300 \mathrm{pCi} / \mathrm{L}$ detection limit for tritium during 1989 (Jaquish and Bryce 1990).

In summary, most of the locations on the Hanford Site where wells are used to supply drinking water are remote. Radioactivity (gross alpha and gross beta) was detected in wells supplying water to residents of Richland during the 1940s and 1950s, but the concentrations were close to the detection limits in effect at that time. More recent monitoring of wells near the Richland water supply wells shows that radionuclide concentrations are below the current detection limits, which are lower than those in effect during the earlier years. At the only location where ground water from a Hanford Site well is open to the public, the FFTF Visitor Center, the occupational radiation dose resulting from maximum observed concentrations of tritium and iodine-129 is below $1 \mathrm{mrem} / \mathrm{y}$. The dose to an occasional visitor would be far less than the occupational dose. 


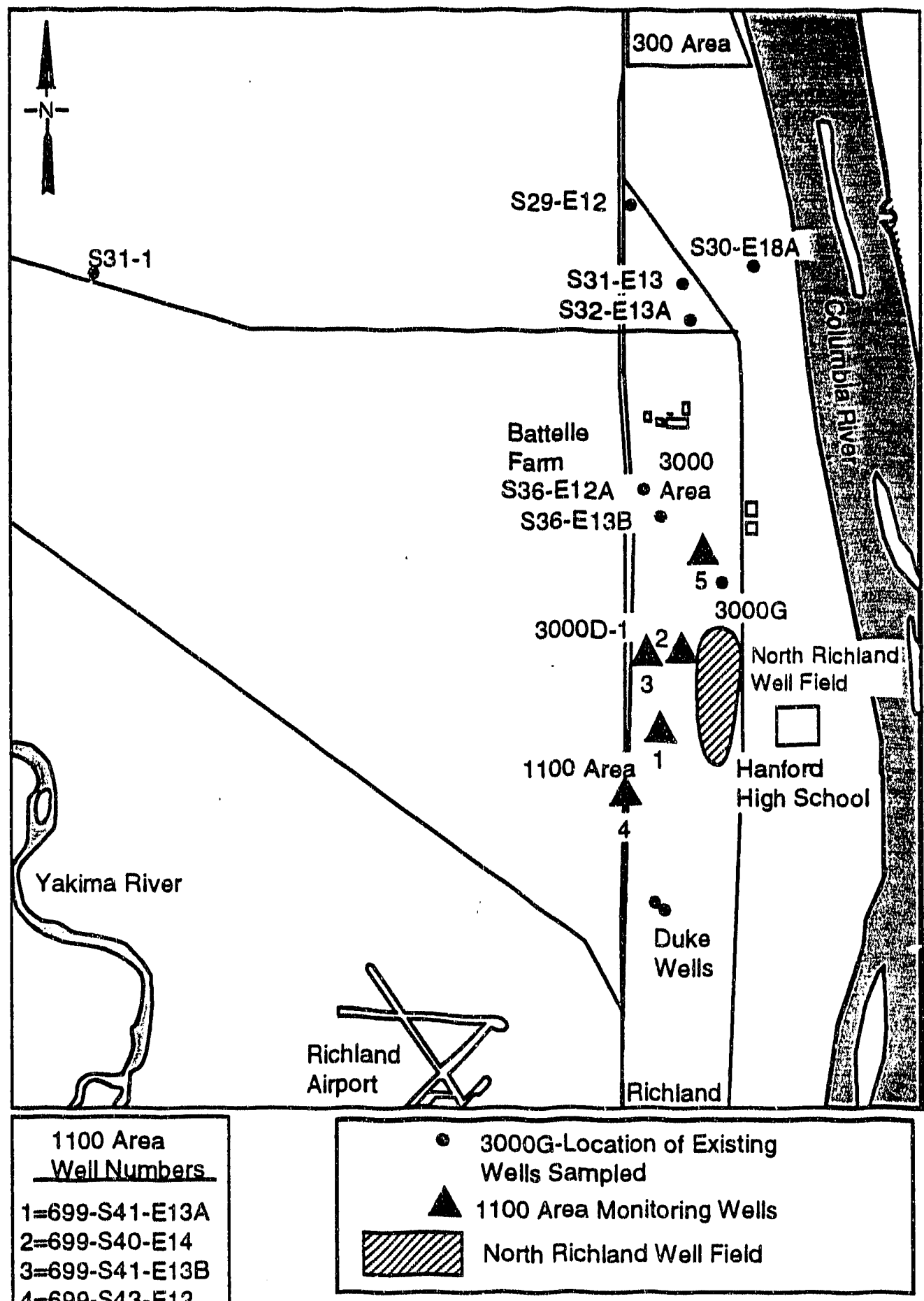

$\$ 9112086.2$

FIGURE 7.3. Location of Ground-Water Monitoring Wells Near the North Richland Well Field (after Bryce and Goodwin 1989) 


\subsection{RIPARIAN WELL PATHWAY}

Use of riparian wells next to the Columbia River has been identified as a possible pathway for radionuclides originating at Hanford to have reached populations or individuals downstream from the Hanford Site. Some or all of the water from riparian wells came from the river, which has received radionuclides discharged from Hanford operations in varying amounts since 1944 .

75,76 The possible radiation doses resulting from use of water from riparian wells were estimated. However, the only direct racionuclide monitoring data available for riparian wells is from sampling of the Kennewick water supply, which mainly comes from riparian wells. (Because the wells were near recharge basins, which elevated the water table, wells for the city of Richland were not considered to be riparian because they would not have pumped river water.) For other individuals using riparian wells, the radiation dose from direct use of Columbia River water was taken as an upper limit because the river is the source of Hanford radionuclides transported to riparian wells. The distribution of radiation doses resulting from use of river water is being determined under the "Columbia River Pathway" portion of the HEDR Project. Radionuclide concentrations in riparian wells were expected to be lower than those in the Columbia River because of a number of factors identified in Section 8.1 of this report.

\subsection{FACTORS AFFECTING IMPACT FROM RIPARIAN WELLS}

The impact to humans in terms of radiation dose that might have been received from use of a riparian well along the Columbia River depends on the following factors:

- concentration of radionuclides in river water

- percentage of river water versus uncontaminated ground water pumped from the riparian well

- the effects of filtration, sorption, and radioactive decay as the water moves through the aquifer toward the well

- uses of the well water. 
Each of these factors is discussed separately in this section of the report.

\subsubsection{Concentration of Radionuclides in River Water}

Results from surface-water calculations performed during Phase I of the HEDR Project were used to estimate the impacts of using water from riparian wells. As previously described, direct radiological monitoring data for riparian wells are limited. Thus, an estimate of impacts was extrapolated from calculated radiation doses for Phase I. These Phase I dose estimates are based on measured and estimated concentrations of radionuclides in the Columbia River.

During Phase I of the HEDR Project, radiation doses were calculated for the Columbia River pathway between the Hanford Site and McNary Dam for the period 1964 through 1966 (PNL 1991b). The 1964 through 1966 period was selected because 1) the greatest number of reactors at the Site was operating at the highest power levels and 2) better radionuclide monitoring data for the Columbia River were available for the 1964 through 1966 period than for previous years (PNL 1991b). Concentrations of radionuclides from Hanford operations were expected to be high in the Hanford reach of the river because it is the closest downstream from the operating reactors.

For the Phase I area and time period, eight radionuclides were considered to estimate doses for the Columbia River pathway: phosphorous-32, zinc-65, arsenic-76, neptunium-239, sodium-24, manganese-56, copper 64, and chromium-51. These eight radionuclides account for more than $80 \%$ of the expected dose to maximally exposed individuals (Napier 1991). However, the relatively short half-lives of these radionuclides may make them relatively less important for riparian weils because ground-water flow is slow compared with flow of the Columbia River. (a) Therefore, radioactive decay will decrease the concentration of those radionuclides reaching a riparian well.

Radionuclide concentrations used in the Phase I dose calculations for the Columbia River pathway were taken directly from historical documents or were calculated. The historical documents that provided the monitoring data

(a) The half-life of seven of these radionuclides ranges from 0.11 to 28 days; the half-life of the eighth is 245 days. 
include Wilson and Foster (1964); Foster and Wilson (1965); Foster et al. (1966); and Honstead, Essig and Soldat (1967). During the period 1964 through 1966, monthly samples of raw river water were collected at the Hanford Site and at Richland and Pasco. Samples of treated drinking water were collected from Richland, Pasco, and Kennewick water supplies. These samples were analyzed for all of the above radionuclides except manganese-56 (which has a 2.6-hr half-1ife). In addition, weekly monitoring data for four of the radionuclides were available for McNary Dam. The concentrations of other radionuclides for which no monitoring data were available were estimated with calculations (PNL 1991b). The distribution of manganese-56 in the river was calculated, as were the distributions of the other radionuclides between monitoring points (PNL 1991b). Preliminary distributions of radiation doses from drinking treated or untreated Columbia River water were calculated on the basis of the determined radionuclide concentrations (PNL 1991b).

\subsubsection{Percentage of River Water from a Riparian Well}

Part or all of the water drawn from a well near the Columbia River may come from sources other than the river, sources such as precipitation on adjacent watersheds or ground-water flow from aquifers not connected with the river. For a riparian well completed in a shallow aquifer next to the Columbia River, the percentage of river water pumped from the well depends on the

- elevation of static hydraulic head in the well

- elevation of the river surface

- pumping rate and duration

- distance from the river

- hydraulic properties of the aquifer.

A detailed hydrogeologic analysis of each riparian well would be needed to accurately determine the relative percentages of river water and uncontaminated ground water pumped from the well. However, a detailed analysis was not performed because conditions would vary from well to well and in response to operation of the well. 
Water will be drawn from the river only if the water level (hydraulic head) in the well during pumping is lower than the elevation of the river surface or if the river level increases above the ground-water level. In most areas along the Columbia River, the hydraulic head of the ground-water system adjacent to the river is higher than that of the river, and ground water flows into the river under natural conditions. An example of this is the water table in the unconfined aquifer at the Hanford Site and in Fran'kl in County (see Figure 4.10). A pumping well could reverse the direction of flow, i.e., cause water to flow from the river to the well by drawing down the aquifer so its hydraulic head is lower than that of the river. As pumping continues, a greater percentage of water would come from the river. It is also possible that a well might draw in river water only at the end of a long pumping cycle. The ground-water flow system near the river is also affected by changes in elevation of the river surface. River surface elevations are changed both by the operations of hydroelectric dams and by seasonal flow variations.

\subsubsection{Effects of Filtration, Sorption, and Radioactive Decay}

Filtration, sorption, and radioactive decay are processes that influence the concentration of radionuclides in ground water. These processes also influence the concentration of radionuclides that move from the Columbia River to riparian wells.

Suspended particles in the Columbia River contain some of the radionuclides that originated at Hanford (PNL 1991b). Radioactive particles in the river result from precipitation of dissolved radionuclides and sorption (binding) of radionuclides onto river sediment, as well as from direct release from the once-through-cooling reactors. As these particles move in a shallow aquifer toward a riparian well, they are removed by filtration in the aquifer. Filtration occurs because ground water flows through pore spaces in sediments that make up an aquifer. These pore spaces will preclude all but the smallest particles from traveling very far. Radionuclides may also be taken up by river biota (NCRP 1984) that will also be filtered out.

Radioactive decay reduces radionuclide concentration. The amount of reduction depends on the time required to reach the well from the river and the half-life of the radionuclide. Travel time from the river to different 
wells may vary greatly, depending on distance from the river to the well, the hydraulic properties of the aquifer (ability to transmit water), the pumping rate of the well, and the extent to which the radionuclide is sorbed in the aquifer. Dissolved radionuclides, particularly cations, may be sorbed by minerals forming the solid matrix (i.e., sand and/or clay) of the aquifer as ground water flows through the aquifer toward a riparian well. Sorption will cause the radionuclide to travel more slowly than the average ground water (Freeze and Cherry 1979), and the concentrations in the well will be further reduced by radioactive decay.

The maximum limit for the concentration of radionuclides from a riparian well is probably similar to that of treated (filtered) river water from the same location. Filtration, sorption, and radioactive decay reduce radionuclide concentrations during flow to a riparian we 11 and during water treatment. In addition to reduction of concentrations by filtration, sorption, and rad oastive decay, radionuclide concentrations in water from a riparian well would be diluted with uncontaminated ground water as the well is pumped.

\subsubsection{Use of Water from Riparian Wells}

The dose that humans may have received from using water from a riparian well contaminated with racionuclides varies because of different exposure pathways. The possible exposure pathways include ingestion (drinking water or consuming irrigated crops), inhalation from showering, and direct dermal (skin) contact (PNL 1991b). However, there is little information available on use of water from riparian wells along the Columbia River.

Potential radiation doses were estimated only for drinking water from riparian wells. However, irrigation may have also been a pathway because certain radionuclides may have been taken up by plants and concentrated in plant tissues or in animals eating the plant matter (NCRP 1984). Such uptake would increase the radiation doses from irrigating with water from riparian wells along the Columbia River. The potential dose from irrigating with Columbia River water was not included in the Phase I dose calculations for the Columbia River pathway (PNL 1991b). The significance of irrigation will be determined as part of ongoing work on the Columbia River pathway. 


\subsection{RADIATION DOSES FROM USE OF RIPARIAN WELLS}

According to the City Engineer, Kennewick pumps approximate? $80 \%$ of its water from a well 400 feet from a lagoon fed by the river and 800 feet from the river itself; another $10 \%$ of the water is pumped from a well 10 feet from the river; and the remaining $10 \%$ is pumped directly from the river and treated. Therefore, it was assumed that nearly all the water for Kennewick comes from the river and that the wells are riparian.

Radiation doses Kennewick residents received from drinking water during 1964 through 1966 range from about 2 to $4 \mathrm{mrem} / \mathrm{y}$ effective dose equivalent (PNL 1991b). Doses received from drinking treated Columbia River water at Pasco and Richland during this period range from 5 to $9 \mathrm{mrem} / \mathrm{y}$ effective dose equivalent and 8 to $14 \mathrm{mrem} / \mathrm{y}$ effective dose equivalent, respectively. The drinking-water doses were calculated for Phase I of the HEDR Project based on estimated river water concentrations and estimates of water treatment plant transmission factors (PNL 1991b). These radiation doses were based on exposure to phosphorous-32, zinc-65, arsenic-76, neptunium-239, sodium-24, manganese-56, copper-64, and chromium-51 (PNL 1991b).

The doses for Kennewick include the effects listed in Section 8.2 for riparian wells. In addition, the lower doses at Kennewick may be partially attributed to the fact that the Yakima River enters the Columbia River about 6 miles upstream from Kennewick's riparian wells. Water from the Yakima may "push" part of the Columbia River water away from the bank and reduce the concentrations of radionuclides on the Kennewick side of the river.

The radionuclide concentrations in downstream riparian wells used by other communities and individuals are expected to have been lower than the concentrations in treated Columbia River water used by Richland. Additional travel time and radioactive decay in the river, sorption of radionuclides onto river sediments, and dilution by tributaries and ground water entering the river reduced the river water concentrations. In addition, radioactive decay, dilution, sorption, and filtration in the ground water further reduced the concentrations in riparian wells. The mediall expected drinking water dose for riparian wells wouid therefore be less than $10 \mathrm{mrem} / \mathrm{y}$ effective dose equivalent. 
The communities downstream of hianford served by ground-water wells that are possibly riparian or a mixture of ground-water well and river sources are listed in Appendix $C$. The appendix also lists population estimates for each community.

8.7 


\subsection{WATERSHED PATHWAY}

Deposition of airborne radionuclides on ground-water recharge areas, subsequent transport through ground water in small watersheds (surface-water and ground-water drainage basins), and then discharge to wells and springs was identified as a possible pathway by which offsite populations or individuals might have been exposed to past releases of radionuclides from the Hanford Site (Appendix A). This process will be referred to as the watershed pathway. For this pathway, the radionuclides deposited on the recharge areas were assumed to be dissolved by infiltrating water and then carried through ground water to a well or spring. Individuals or populations who used the well or spring for drinking water would have been exposed to the radionuclides.

\subsection{APPROACH AND ASSUMPTIONS}

To evaluate the radiation dose that a person drinking ground water in the watershed pathway might have received, a scenario was developed in which a hypothetical spring supplied drinking water and all of the spring's water came from recharge within a small watershed. Such a scenario is possible in some areas near the Hanford Site. Springs that discharge ground water collected in small recharge areas exist on the slopes of Rattlesnake Mountain and the Saddle Mountains west of the Hanford Site (Gephart et al. 1979).

The largest radionuclide releases to the atmosphere at the Hanford site occurred during the early years of operation and originated from the chemical separation of irradiated fuel (PNL 1991a). The expected average deposition rate of radionuclides on the hypothetical watershed was determined for 1945, the year of highest deposition, based on Phase I atmospheric-transport calcu?ations (PNL 1991c). The resulting concentrations of radionuclides in water from the hypothetical spring were then calculated, as discussed below, and the effective dose equivalent from drinking the water was determined.

Because this analysis is not based on an actual case, the results should not be interpreted as a prediction of the radiation dose actually received by any person or group. The analysis is intended to estimate the magnitude of the "worst case" radiation dose that might be expected through such a pathivay. 
Therefore, several assumptions have been made which tend to result in a high estimate of the concentration of radionuclides in the spring water:

- The watershed is located in HEDR Census Division BE1, which was an area of relatively high iodine-131 deposition, according to the Phase I atmospheric-transport calculations.

- Other radionuclides are deposited on the watershed in proportion to the deposition of iodine-131 predicted as part of the HEDR Phase I atmospheric-transport pathway.

- All of the radionuclides deposited on the watershed are "washed off" by precipitation and dissolved in the infiltrating ground water.

- No radioactive decay of radionuclides occurs during atmospheric transport and before infiltration.

- The radionuclides are not dispersed during transport through either the unsaturated zone or the aquifer.

- The radionuclides are not diluted by mixing with uncontaminated ground water.

- The average travel time for ground water in the watershed is 1 year.

As noted, these assumptions result in a "worst case" estimate. In reality, some deposited radionuclides would probably be insoluble or would be sorbed by particles in the soil. Also, during the period between deposition and infiltration, decay would reduce the concentration of radionuclides with short half-lives. These periods could be several months in the semiarid climate of southeastern Washington State. Radionuclide transport would be further reduced by dispersion in the unsaturated zone and ground water. The assumed average travel time of 1 year through the ground water is probably short for some of the flow paths to springs on Rattlesnake Mountain. A longer travel time would result in lower radionuclide concentrations at the spring because the radionuclides would be decaying. Also, the concentration of radionuclides would probabiy be reduced by mixing with uncontaminated ground water in the aquifer.

\subsection{WATERSHED DEPOSITION CALCULATIONS}

The first step in the arialysis was to determine the deposition rate at the watershed location for each of the radionuclides released during 1945. As 
part of the Phase I atmospheric-transport calculations, normalized releases in $\mathrm{Ci} / \mathrm{y}$ were determined for each of the radionuclides present in the processed fuel. The deposition of iodine-131 from the atmosphere in each of the HEDR census divisions was also determined during Phase I through atmospherictransport modeling. It was sisumed that the ratio of deposition rate to release term was the same for each radionuclide. In reality, iodine deposits more readily than other radionuclides considered in the watershed pathway, so this assumption results in more deposition than would actually occur. The deposition rate for each radionuclide was calculated from the deposition of iodine-131 as

$$
D=R\left(D_{\text {iodine-131 }} / R_{\text {iodine-131 }}\right)
$$

where $D=$ average deposition rate for the radionuclide of interest $\left(\mathrm{pCi} / \mathrm{m}^{2} \mathrm{y}\right)$

$R=$ normalized release term to the atmosphere for the radionuclide of interest ( $\mathrm{Ci} / \mathrm{y})$

$\mathrm{D}_{\text {iodine-131 }}=$ average atmospheric deposition rate of iodine-131 $\left(\mathrm{pCi} / \mathrm{m}^{2} \mathrm{y}\right)$

$R_{\text {iodine-131 }}=$ normalized atmospheric release term for iodine-131 $(\mathrm{Ci} / \mathrm{y})$.

To calculate the initial concentration of each radionuclide in infiltrating water, the deposition rate was divided by the rate of water infiltration:

$$
A_{0}=\frac{D}{q}
$$

where $q$ is the rate of water infiltration $(\mathrm{m} / \mathrm{y})$. The rate of wister infiltration was assumed to be $3.5 \mathrm{~cm} / \mathrm{y}(0.035 \mathrm{~m} / \mathrm{y})$ based on work by Gutknecht et a1. (1980). To determine the travel time through the unsaturated zone to reach ground water, the assumed depth to ground water, 10 feet ( 3 ineters), was divided by the velocity of the infiltrating water, which is the water infiltration rate $(0.035 \mathrm{~m} / \mathrm{y})$ divided by an assumed moisture content $(0.10)$

$$
t_{v z}=\frac{d \theta}{q}
$$


where $t_{v z}=$ travel time to reach the ground water $(y)$

$d=$ distance from surface to the ground water $(m)$

$\theta=$ soil moisture content $\left(\mathrm{cm}^{3} / \mathrm{cm}^{3}\right)$.

The resulting travel time through the unsaturated zone was 8.7 years. With an assumed travel time of 1 year in the ground water, the total time required for radionuclides deposited on the watershed to reach the spring was 9.7 years. The only factor considered to reduce the concentration was radioactive decay during the assumed 9.7-year travel time to the spring. Therefore, the concentration of each radionuclide at the spring was calculated from

$$
A=A_{0} e^{-t\left(0.693 / t_{1 / 2}\right)}
$$

where $A=$ radionuclide concentration at the spring $(p C i / L)$

$A_{0}=$ the initial concentration of the radionuclide $(\mathrm{pCi} / L)$ in infiltrating water

$t=$ travel time $(y)$

$t_{1 / 2}=$ half-life of the radionuciide $(y)$.

To screen the list of possible radionuclides, the concentrations in the spring were first calculated assuming none of the radionuclides was sorbed on soil in the unsaturated zone or the geologic formations within the aquifer. The results of this screening calculation are given in Table 9.1. The results indicate that ruthenium-106 is the only radionuclide that arrives at the spring in concentrations close to its drinking-water standard, which is $30 \mathrm{pCi} / \mathrm{L}$ (EPA 1976). The drinking-water standard was used to screen the list of radionuclides for those that would contribute to dose.

Some radionuclides, particularly cations, will be adsorbed onto minerals in the soil and aquifer. This slows the transport of adsorbed radionuclides toward the spring. The amount by which transport of a particular radionuclide will be slowed under particular geochemical conditions is quantified by the distribution coefficient $\left(K_{d}\right)$. Geochemical evaluations of ruthenium-106 (Ames and Rai 1978) demonstrated a wide range (0 to 752 milliliters per gram [ml/g]) of possible distribution coefficients (higher $K_{d} s$ indicate greater sorption). 
TABLE 9.1. Summary of Radionuclide Screening for Watershed Pathway Calculation (Assuming No Sorption of Radionuclides)

\begin{tabular}{|c|c|c|c|c|c|}
\hline Radionuclide & Half-Life & $\begin{array}{c}\text { Normal ized } \\
\text { Release } \\
\text { Term } \\
(C i / y) \\
\end{array}$ & $\begin{array}{l}\text { Deposition } \\
\text { Rate } \\
\left(p C i / m^{2} y\right)\end{array}$ & $\begin{array}{c}\text { Concentration } \\
\text { in Infiltration } \\
(\mathrm{pCi} / \mathrm{L}) \\
\end{array}$ & $\begin{array}{c}\text { Spring } \\
\text { Concentration } \\
\text { (nCi/L) } \\
\end{array}$ \\
\hline Tritium & $12.3 \mathrm{y}$ & 8.5 & 946 & 27 & 16 \\
\hline Cobalt-60 & $5.3 \mathrm{y}$ & 3.2 & 356 & 10 & 2.7 \\
\hline Strontium-89 & 50.5 days & 1.1 & 122 & 3.5 & 0 \\
\hline Strontium-90 & $28.8 y$ & 0.01 & 1.45 & 0.04 & 0.03 \\
\hline Yttrium-9]. & 58 days & 1.3 & 145 & 4.1 & 0 \\
\hline Zirconium-95 & 64 days & 1.5 & 167 & 4.8 & 0 \\
\hline Niobium-95 & 35 days & 1.2 & 134 & 3.8 & 0 \\
\hline Niobium-95M & $84.1 \mathrm{hr}$ & 0.01 & 1.22 & 0.03 & 0 \\
\hline Ruthen ium-103 & 39.6 days & 12,000 & $1,340,000$ & 38,152 & 0 \\
\hline Ruthen ium." 106 & 307 days & 860 & 95,700 & 2734 & 3.4 \\
\hline Iodine-131 & 0 ays & 1.0 & $1,560,000$ & 44,510 & 0 \\
\hline Cesium-137 & $30 y$ & 0.02 & 1.78 & 0.05 & 0.04 \\
\hline Cerium-144 & 284 days & 0.4 & 49 & 1.4 & 0 \\
\hline
\end{tabular}

However, $K_{d}=0 \mathrm{ml} / \mathrm{g}$ was used in the calculations summarized in Tables 9.2, 9.3 and 9.4. Assuming even a small $k_{d}$ of 1 , no ruthenium-106 was predicted to reach the spring.

In a sensitivity analysis, each of the assumed parameters used in the calculation was varied by a reasonable amount (Table 9.2). The range of spring concentrations predicted while varying each parameter independently (assuming all other parameters were constant) is summarized in Table 9.3.

The concentrations of ruthenium-106 at the spring predicted in this sensitivity analysis ranged from 0 to $68 \mathrm{pCi} / \mathrm{L}$.

\subsection{RADIATION DOSES FROM WATERSHED DEPOSITION CALCULATIONS}

The expected dose over a l-year period from drinking water with the calculated concentrations of radionuclides was determined using the GENII computer software system (Napier et a1. 1988a, 1988b). This software has been 
TABLE 9.2. Summary of Parameter Variations for the Watershed Sensitivity Analysis

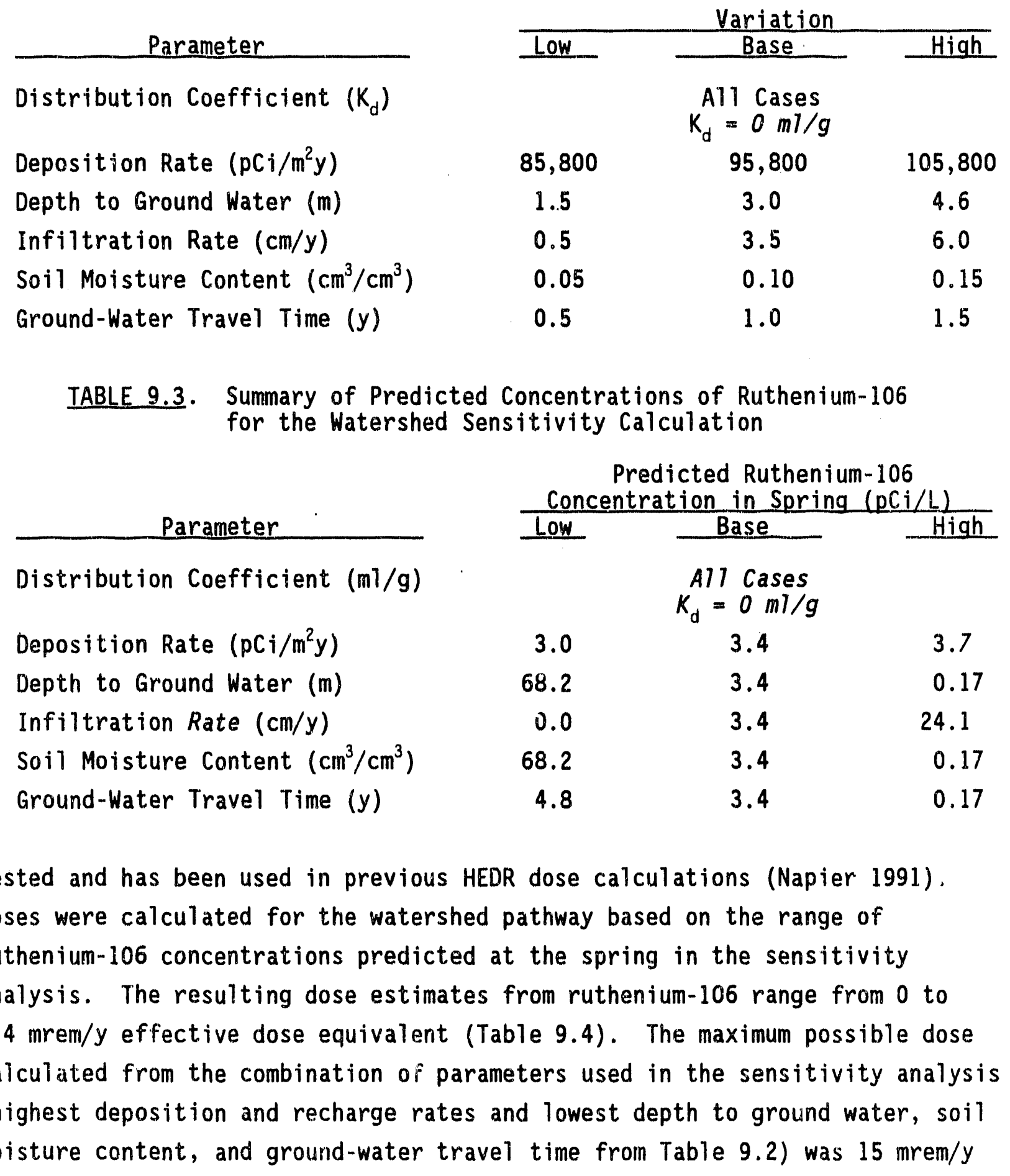


effective dose equivalent. All doses calculated for this pathway are well below the TSP dose decision level of $100 \mathrm{mrem} / \mathrm{y}$ effective dose equivalent for an adult.

TABLE 9.4. Summary of Dose Calculations for the Watershed Sensitivity Calculation

\section{Parameter}

Distribution Coefficient (ml/g)

Deposition Rate $\left(p C i / m^{2} y\right)$

Depth to Ground Water (m)

Infiltration Rate $(\mathrm{cm} / \mathrm{y})$

Soil Moisture Content $\left(\mathrm{cm}^{3} / \mathrm{cm}^{3}\right)$

Ground-Water Travel Time $(y)$

\begin{tabular}{|c|c|c|}
\hline \multirow[b]{2}{*}{ Low } & \multicolumn{2}{|l|}{ Dose $(\mathrm{mrem} / \mathrm{y})$} \\
\hline & Base & High \\
\hline & $\begin{aligned} A 11 & \text { Cases } \\
K_{\mathrm{d}} & =0 \mathrm{ml} / \mathrm{g}\end{aligned}$ & \\
\hline 0.06 & 0.07 & 0.07 \\
\hline 1.4 & 0.07 & 0.004 \\
\hline 0.0 & 0.07 & 0.5 \\
\hline 1.4 & 0.07 & 0.003 \\
\hline 0.1 & 0.07 & 0.003 \\
\hline
\end{tabular}




\subsection{CONCLUSIONS AND RECOMMENDATION}

Ground-water monitoring has generated a considerable amount of information on the distribution of radionuclides in the ground water at the Hanford Site over time. Changes in the monitoring technologies (described in Section 5) have resulted in improvements in the quality of information that is available. During the early years (1940s through the early 1960s), only gross alpha and gross beta measurements were available on a routine basis. More recently, detailed information is available on the concentrations of specific radionuclides in Hanford Site ground water.

The improvements in the quality of monitoring results have changed the interpretations of the ground-water contamination data. For example, during the early 1960s, the discovery that tritium was a product of uranium fission prompted sampling and analysis of ground water in the unconfined aquifer to detect tritium. At the time, the lowest level of detection for tritium was $10,000 \mathrm{pCi} / \mathrm{L}$. When tritium was found to be present in the unconfined aquifer, as reported by Brown (1962b); the tritium plume was interpreted as having reached the Columbia River (see Figure 6.24). In 1963, additional monitoring wells and improved analytical techniques suggested that the prior analyses and interpretations were not correct. Therefore, the tritium plume was interpreted by Haney (1963) to be farther back from the river than was previousiy thought (see Figure 6.26).

Radiation doses that the public received from discharge of Hanford Site ground water containing radionuclides to the Columbia River were small (compared with the TSP dose decision levels). The dose attributed to ground-water discharge to the river during 1990 was $0.02 \mathrm{mrem} / \mathrm{y}$ effective dose equivalent (Woodruff et a7. 1991). This dose was calculated by the difference between measured upstream and downstream concentrations of tritium and iodine-129 in the river during 1990 when the ground-water discharge was high compared with previous years (Figures 6.45 and 6.46). Monitoring results for wells in Frank 1 in County show that doses from iodine-129 were $2 \times 10^{-7}$ to $2 \times 10^{-5}$ $\mathrm{mrem} / \mathrm{y}$ e ffective dose equivalent $7 \times 10^{-6}$ to $7 \times 10^{-4} \mathrm{mrem} / \mathrm{y}$ dose to the 
thyroid, well below the TSP dose decision levels ${ }^{(a)}$ of $100 \mathrm{mrem} / \mathrm{y}$ effective dose equivalent for an aduit (although the source of the iodine-129 was never determined) (IWG 1987). Uranium in Frankl in County wells was shown to be of natural origin and not from the Hanford Site (WDSHS 1988).

Use of water from wells on the Hanford Site that were contaminated by radionuclides did not result in significant radiation doses to the public. Only the Visitor Center at the FFTF is accessible to the public. The dose from tritium at the FFTF, which was highest during 1977 (51,000 pCi/L) resulted in 1 mrem annual dose to workers, based on a 40-hour work week and a $220-\mathrm{L} / \mathrm{y}$ intake. The radiation doses to occasional visitors would be much less than the calculated doses to workers. As an example, the potential dose to a visitor drinking $1 \mathrm{~L}$ of water was calculated to be $0.0006 \mathrm{mrem} / \mathrm{y}$ effective dose equivalent.

The radiation doses from using water from riparian wells were estimated to be small, although they were difficult to quantify because no direct monitoring data are available. The maximum radionuclide concentrations in riparian wells are expected to be similar to those for treated (filtered) river water. Maximum possible radiation doses from use of riparian wells were estimated based on doses from direct use of water from the Columbia River.

Kennewick is the nearest municipality downstream of the Hanford Site that is supplied by riparian wells. Radionuclide concentrations in the Kennewick water supply were monitored over time, and these data therefore represent the only direct radionuclide monitoring data for riparian wells. During Phase I of the HEDR Project, the distribution of doses resulting from drinking water from the Kennewick water supply was estimated for 1964 through 1966, which was the period of highest radionuclide discharge to the river from the operating reactors at the Hanford Site (PNL 1991b). The range in dose calculated for riparian wells downstream of Hanford was 2 to $14 \mathrm{mrem} / \mathrm{y}$ effective dose equivalent.

(a) Shleien, B. 1992. "Scoping Document for Determination of Temporal and Geographic Domains for the HEDR Project." Prepared for the Technical Steering Panel, approved by the TSP in Apri7 1992. Washington State Department of Ecology, 1-800-545-5581. 
Radionuclide concentrations were monitored in water withdrawn directly from the river and treated in Richland and Pasco. These concentrations provide an estimate for maximum possible impacts of drinking water from riparian wells. Results from Phase I (PNL 1991b) show the median dose from drinking treated river water in Richland was $10 \mathrm{mrem} / \mathrm{y}$ effective dose equivalent during 1964 through 1966. The dose from drinking riparian well water is expected to be lower than the dose from drinking river water because of the factors reducing radionuclide concentrations in wells (described in Section 8.1).

The range in doses calculated for the watershed pathway was less than $1 \mathrm{mrem} / \mathrm{y}$ for a range of possible parameters used in the calculation. The maximum possible dose by combining the "worst" parameters in the calculation was $15 \mathrm{mrem} / \mathrm{y}$ effective dose equivalent. In the calculation, ruthenium-106 was the only radionuclide to reach the hypothetical well or spring through the shallow ground-water system in concentrations close to drinking-water standards.

Analysis of the ground-water pathways and extensive review of available publications on ground water at the Hanford Site indicate that ground water did not make a significant contribution to dose during the study period (1944 to present). Even at locations where ground water was used directly or where surface water containing radionuclides from ground water was used, the contributions to dose were small.

The TSP has reviewed and approved this document, thus, evaluation of the ground-water transport pathway is considered complete. The recommendation from analysis of the ground-water pathways identified by the TSP is that further work on the ground-water pathway be limited to tracking ground-water studies at the Hanford Site and surrounding environs (i.e., wells in Franklin County). 


\subsection{REFERENCES}

Albenesius, E. L. 1959. "Tritium as a Product of Fission." Phisics Review Letters $3: 274$.

Ames, L. L., and D. Rai. 1978. Radionuclide Interactions with Soil and Rock Media. EPA 520/6-78-007, Vol. 1, U.S. Environmental Protection Agency, Office of Radiation Programs, Las Vegas, Nevada.

Baker, S. M., J. L. Devary, R. F. Lorang, R. P. Elmore, A. J. Rossi, and M. D. Freshiey. 1988. U1/U2 Uranium Plume Characterization, Remedial Action Review and Recommendation for Future Action. WHC-EP-0133, Westinghouse Hanford Company, Richland, Washington.

Bauer, H. H., J. J. Vaccaro, and R. C. Lane. 1984. Maps Showing Ground-Water Levels in the Columbia River Basalt and Overlying Materials, Spring 1983, Southeastern Washington. Water-Resources Investigations Report 84-4360, U.S. Geological Survey, Tacoma, Washington.

Bierschenk, W. H. 1957. Hydraulic Characteristics of Hanford Aquifers. HW-48916, General E.lectric Company, Hanford Atomic Products Operation, Richland, Washington.

Bierschenk, W. H., ed. 1958a. Chemical Effluents Technology Waste Disposal Investigations, October, November, December, 1957. HW-54848, General Electric Company, Hanford Atomic Products Operation, Richland, Washington.

Bierschenk, W. H., ed. 1958b. Chemical Effluents Technology Waste Disposal Invest.igations, January, February, March, 1958. HW-55841-RD, General Electric Company, Hanford Atomic Products Operation, Richland, Washington.

Bierschenk, W. H., ed. 1958c. Chemical Effluents Technology Waste Disposal Investigations, April, Mav, June, 1958. HW-57002-RD, General Electric Company, Hanford Atomic Products Operation, Richland, Washington.

Bierschenk, W. H., ed. 1958d. Chemical Effluents Technology Waste Disposal Investigations, July. Auqust, September, 1958. HW-58023-RD, General Electric Company, Hanford Atomic Products Operation, Richland, Washington.

Bierschenk, W. H., ed. 1959a. Chemical Effluents Technology Waste Disposal Investigations, October, November, December, 1958. HW-58811-RD, Genera1 Electric Company, Hanford Atomic Products Operation, Richland, Washington.

Bierschenk, W. H. 1959b. Aquifer Characteristics and Ground-Water Movement at Hanford. HW-50601, General Electric Company, Hanford Atomic Products Operation, Richland, Washington.

Bierschenk, W. H., ed. 1959c. Chemical Effluents Technology Waste Disposal Investigations, January, February, March, 1959. HW-60163-RD, General Electric Company, Hanford Atomic Products Operation, Richland, Washington. 
Bierschenk, W. H., ed. 1959d. Chemical Effiuents Technology Waste Disposal Investigations, April. May, June, 1959. HW-61197-RO, General Electric Company, Hanford Atomic Products Operation, Richland, Washington.

Brown, D. J., ed. 1957a. Chemical Effluents Technology Waste Disposal Inves: tiqations, July. Auqust. September, 1956. HW-49465, General Electric Company, Hanford Atomic Products Operation, Richland, Washington.

Brown, D. J., ed. 1957b. Chemical Effluents Technology Waste Disposal Investigations, October, November, December, 1956. HW-50186, General Electric Company, Hanford Atomic Products Operation, Richland, Washington.

Brown, D. J. 1957c. Chemical Effluents Tecinology Waste Disposal Investigations, January February, March. 1957. HW-51095, General ETectric Company, Hanford Atomic Froducts Operation, Richland, Washington.

Brown, D. J. 1957d. Chemical Effluents Technology Waste Disposal Investigations, April. May, June, 1957. HW-53225, Genera1 Electric Company, Hanford Atomic Products Operation, Richland, Washington.

Brown, D. J. 1957e. Chemical Effluents Technology Waste Disposal Investigations, July. Auqust. September, 1957. HW-54655, General Electric Company, Hanford Atomic Products Operation, Richland, Washington.

Brown, D. J. 1962a. Chemical Effluents Technology Waste Disposal Investigations, July - December, 1961. HW-72645-RD, General Electric Company, Hanford Atomic Products Operation, Richland, Washington.

Brown, D. J. 1962b. Chemical Effluents Technology Waste Disposal Investigations, January - June, 1962. HW-74915-RD, General Electric Company, Hanford Atomic Products Operation, Richland, Washington.

Brown, D. J. 1963. Chemical Effluents Technology Waste Disposal Investigations, July - December, 1962. HW-76120-RD, General Electric Company, Hanford Atomic Products Operation, Richland, Washington.

Brown, D. J, 1964. Chemical Effluents Technology Waste Disposa]_Investigations, January - December, 1964. HW-84549, General Electric Company, Hanford Atomic Products Operation, Richland, Washington.

Brown, D. J. 1965. Chemical Effluents Technology Waste Disposal Investigations, January - June, 1965. BNWL-CC-285, Pacific Northwest Laboratory, Richland, Washington.

Brown, D. J., and W. A. Haney. 1964. Chemical Effluents Technology Waste Disposal Investigations, July - December, 1963 - . The Movement of Contaminated Ground Water from the 200 Areas to the Columbia River. HW-80909, General Electric Company, Hanford Atomic Products Operation, Richland, Washington. 
Brown, D. J., and R. G. Ibatuan. 1958. Hanford Wells. HW-44355, Rev. 1, General Electric Company, Hanford Atomic Products Operation, Richland, Washington.

Brown, D. J., and J. R. Raymond. 1962a. "Radiologic Monitoring of Ground Water at the Hanford Project." Journal American Water Works Association 54(10): 1201-1212.

Brown, D. J., and J. R. Raymond, 1962b. Hanford Experience in the Radiological Monitoring of Ground Water. HW-SA-2566, General Electric Company, Hanford Atomic Products Operation, Richland, Washington.

Brown, R. E. 1966. Hydrologic Inter-Area Relationshios as Indicated by Rising Heads in Confined Aquifers, Pasco Basin, Washington. BNWL-SA-686, Pacific Northwest Laboratory, Richland, Washington.

Bryce, R. W., G. W. Gee, F. A. Spane, and B. N. Bjornstad. 1991. "Hydrogeology of the Hanford Site: Implications for Contaminant Transport." Presented at the Geological Society of America Annual Meeting, October 21-24, San Diego, California. PNL-SA-19802, Pacific Northwest Laboratory, Richland, Washington.

Bryce, R. W., and S. M. Goodwin. 1989. Borehole Summary Report for Five Ground-Water Monitoring Wells Constructed in the 1100 Area. PNI-6824, Pacific Northwest Laboratory, Richland, Washington.

Buske, N., and L. Josephson. 1986. "Spring 1986 Data Report." SEARCH Technical Services, Davenport, Washington.

Cearlock, D. B., K. L. Kipp, and D. R. Freidrichs. 1975. The Transmissivity Iterative Calculation Routine - Theory and Numerical Implenientation.

BNWL-1706, Pacific Northwest Laboratory, Richland, Washington.

Cline, C. S., J. T. Rieger, and J. R. Raymond. 1985. Ground-Water Monitoring at the Hanford Site, January - December 1984. PNL-5408, Pacific Northwest Laboratory, Richland, Washington.

Clukey, H. V. 1954a. Tabulation of Radioactive Liquid Waste Disposal Facilities. HW-33305, General Electric Company, Hanford Atomic Products Operation, Richland, Washington.

Clukey, H. V. 1954b. 300-Area Radioactive Liquid Waste Streams Disposal. HW-32762, General Electric Company, Hanford Atomic Products Operation, Richland, Washington.

Clukey, H. V. 1956. Tabulation of Radioactive Liquid Waste Disposal Facili. ties. HW-43121, General Electric Company, Hanford Atomic Products Operation, Richl and, Washington. 
Converse Ward Davis and Dixon, Inc. 1981. Survey of Selected Basalt Water Wells, Pasco Basin. Washington. RHO-BWI-C-101, Rockwell Hanford Operations, Richland Washington.

Delegard, C. H., R. T. Kimura, A. G. Law, R. C. Routson, and R. L. Weiss. 1986. Characterization and Anion Exchange Removal of Uranium from Hanford Ground Water. RHO-RE-SA-116 P, Rockwell Hanford Operations, Richland Washington.

Dirkes, R. L. 1990. 1988 Hanford Riverbank Springs Characterization Report. PNL-7500, Pacific Northwest Laboratory, Richland, Washington.

DOE (see U.S. Department of Energy).

Dove, F. H., C. R. Cole, M. G. Foley, $\because$. Bond, R. E. Brown, W. J. Deutsch, M. D. Freshley, S. K. Gupta, P. J. Gutknecht, W. L. Kuhn, J. W. Lindberg, W. A. Rice, R. Schalla, J. F. Washburn and J. T. Zellmer. 1982. Assessment of Effectiveness of Geologic Isolation Systems. AEGIS Technology Demonstration for a Nuclear Waste Repository ir Basalt. PNL-3632, Pacific Northwest

Laboratory, Richland, Washington.

E. I. duPont de Nemours and Co., Inc. (duPont). 1945. Operation of Hanford Engineering Works: Medical Department - Health Instrument Section - Functions, Organization, and Equipment. HAN-73214 BK7 DEL, E. I. duPont de Nemours and Co., Inc., Hanford Engineer Works, Richland, Washington.

Early, T. 0., S. H. Hall, and V. G. Johnson. 1988. "Tritium, Carbon-14, and lodine-129 as Indicators for Localized Vertical Recharge Along an Anticl ine in the Columbia River Basalts Using a Decay-Corrected Mixing Model." Proceedings of the Association of Ground-Water Scientists and Engineers' Ground-Water Geochemistry Conference, February 16-18, 1988, Denver, Colorado.

Earth Sciences Personnel. 1956a. Earth Sciences' Waste Disposal Monitoring Activities Summary, January, 1956. HW-6,3 i49, General Electric Company, Hanford Atomic Products Operation, Richiand, Washington.

Earth Sciences Personnel. 1956b. Earth Sciences' Waste Disposal Monitoring Activities Summary, April, 1956. HW-44354, General Electric Company, Hanford Atomic Products Operation, Richland, Washington.

Eddy, P. A., C. S. Cline, and L. S. Prater. 1982. Radiological Status of the Ground Water Beneath the Hanford Site, January - December, 1981. PNL - 237 , Pacific Northwest Laboratory, Richland, Washington.

Eddy P. A., D. A. Myers and J. R. Raymond. 1978. Vertical Contamination in the Unconfined Groundwater at the Hanford Site, Washington. PNL-2724, Pacific Northwest Laboratory, Richland, Washington.

Eddy, P. A., L. S. Prater, and J. T. Rieger. 1983. Ground-Water Surveillance at the Hanfori Site for CY-1982. PNL-4659, Pacific Northwest Laboratory, Richland, Washington. 
Eddy, P. A., and J. S. Wilbur. 1980. Radiological Status of the Ground Water Beneath the Hanford Project, January - December, 1979. PNL-3346, Pacific Northwest Laboratory, Richland, Washington.

Eddy, P. A., and J. S. Wilbur. 1981. Radiological Status of the Ground Water Beneath the Hanford Site, January - December, 1980. PNL-3768, Pacific Northwest Laboratory, Richland, Washington.

Eliason, J. R. 1966a. Earth Sciences Waste Disposal Investigations, July = December, 1965. BNWL-CC-574, Pacific Northwest Laboratory, Richland, Washington.

Eliason, J. R. 1966b. Earth Sciences Waste Disposal Investigations, January - June, 1966. BNWL-CC-887, Pacific Northwest Laboratory, Rich1 and, Washington.

Eliason, J. R. 1967a. Field Evaluation of Ground Disposal of Reactor Effluent - 1301-N Crib. BNWL-CC-1032, Pacific Northwest Laboratory, Richiand, Washington.

Eliason, J. R. 1967b. Earth Sciences Waste Disposal Investigations, July December, 1966. BNWL-432, Pacific Northwest Laboratory, Richland, Washington.

Eliason, J. R. and B. F. Hajek. 1967. Ground Disposal of Reactor Cuolant Effluent. BNWL-CC-1352, Pacific Northwest Laboratory, Richland, Washington.

EPA (see U.S. Environmental Protection Agency).

Energy Research and Development Administration (ERDA). 1975. Final Environmental Impact Statement on Waste Management Operations, Hanford Reservation, Richland, Washington. ERDA-1538, Washington, D.C.

Essig, T. H. 1968. Radiological Status of the Ground Water Beneath the Hanford Project, July - December, 1967. BNWL-835, Pacific Nirthwest Laboratory, Richland, Washington.

Essig, T. H. 1971. "Radiological Impact of Hanford Waste Disposal on Groundwater Quality." Presented at Health Physics Society Annual Meeting, New York, New York, July 11-15, 1971. BNWL-SA-3744, Pacific Northwest Laboratory, Richland, Washington.

Evans, J. C., R. W. Bryce, D. J. Bates, and M. L. Kemrer. 1990. Hanford Site Ground.Water Surveillance for 1989. PNL-7396, Pacific Northwest Laboratory, Richland, Washington.

Foster, R. F., and R. H. Wilson. 1965. Evaluation of Radiological Conditions in the Vicinity of Hanford for 1964. BNWL-90, Pacific Northwest Laboratory, Richland, Wastington. 
Foster, R. F., D. Moore, T. H. Essig, and J. K. Soldat. 1966. Evaluation of Fadiological Conditions in the Vicinity of Hanford for 1965. BNWL-316, Pacific Northwest Laboratory, Richland, Washington.

Freeze, R. A., and J. A. Cherry. 1979. Groundwater. Prentice-Hall, Inc., Englewood Cliffs, New Jersey.

Freshley, M. D. 1989. Ressonse to TSP Directive 88-4, Ground-Water Contamination Data. PNL-6847 HEDR, Pacific Northwest Laboratory, Richland, Washington.

Freshley, M. D., and M. J. Grahain. 1988. Estimation of Ground-Water Travel Time at the Hanford Site: Description, Past Work, and Future Needs. PNL-6328, Pacific Northwest Laboratory, Richland, Washington.

Gamertsfelder, C. C. 1946a. H. I. Report on the 200 Areas and Environs for the Week Ending January 9, 1946. HW-7-3194, E. I. duPont de Nemours and Company, Hanford Engineer Works, Richland, Washington.

Gamertsfelder, C. C. 1946b. H. I. Report on the 200 Areas and Environs for the Week Ending January 16, 1946. HW-7-32.35, E. I. duPont de Nemours and Company, Hanford Engineer Works, Richland, Washington.

Gamertsfelder, C. C. 1946c. H. I. "Environs" Report on the 200 Areas and Environs for the Week Ending July 17, 1946. HW-7-4423, E. I. duPont de Nemours and Company, Hanford Engineer Works, Richland, Washington.

Gamertsfelder, C. C. 1946d. H. I. "Environs" Report on the 200 Areas and Environs for the Week Ending July 24, 1946. HW-7-4440, E. I. duPont de Nemours and Company, Hanford Engineer Works, Richlarid, Washington.

Gamertsfelder, C. C. 1946e. H.I. Section Report for February 1946. HW-7-3517, E. I. duPont de Nemour's and Company, Hanford Engineer Works, Richland, Washington.

Gamertsfelder, C. C. 1946f. H. I. Section Report for March 1946. HW-7-3694, E. I. duPont de Nemours and Company, Hanford Engineer Works, Richland, Washington.

Gamertsfelder, C. C. 1946g. H. I. Section Report for April 1946. HW-7-3933, E. I. duPont de Nemours and Company, Hanford Engineer Works, Rich 1 and, Washington.

Gamertsfelder, C. C. 1946h. H. S. Section Report for June 1946. HW-7-4312, E. I. duPont de Nemours and Company, Hanford Engineer Works, Richland, Washington.

Gamertsfelder, C. C. 1946i. H. I. Section Report for Ju7y 1946. HW-7-4474, E. I. duPont de Nemours and Company, Hanford Engineer Works, Richland, Washington. 
Gamertsfelder, C. C. 1946j. H. I. Section Report for Auqust 1946. HW-7-4699, E. I. duPont de Nemours and Company, Hanford Engineer Works, Richland, Washington.

Gee, G. W., and P. R. Heller. 1985. Unsaturated Water Flow at the Hanford Site: A Review of Literature and Annotated Bibliography. PNL-5428, Pacific Northwest Laboratory, Richland, Washington.

Gephart, R. E., F. A. Spane, Jr., L. S. Leonhart, D. A. Palombo, and S. R. Strait. 1979. "Pasco Basin Hydrology." In Hydrologic Studies Within the Columbia Plateau. Washington: An Integration of Current Knowledge, pp. II I-1 through III-235. RHO-BWI-St-5, Rockwell Hanford Operations, Richland, Washington.

Gilmore, T. J., J. V. Borghese, and D. R. Newcomer. 1991. Evaluations of the Effects of the Columbia River on the Unconfined Aquifer Beneath the 100-N Area. PNL-7646, Pacific Northwest Laboratory, Richland, Washington.

Graham, M. J. 1983. Hydrogeochemical and Mathematical Analyses of Aquifer Intercommunication, Hanford Site, Washington State. PhD Dissertation, Indiana University, Bloomington, Indiana.

Graham, M. J., M. D. Hall, S. R. Strait, and W. R. Brown. 1981. Hydrology of the Separations Area. PHO-ST-42, Rockwell Hanford Operations, Richland, Washington.

Graham, M. J., G. V. Last, and K. R. Fecht. 1984. An Assessment of Aquifer Intercommunication in the $B$ Pond-Gable Mountain Pond Area of the Hanford Site. RHO-RE-ST-12 P, Rockwell Hanford Operations, Richland, Washington.

Gutknecht, P. J., W. A. Rice, C. R. Cole, and M. D. Freshiey. 1980. Pasco Basin Hydrometeorological Study. RHO-BWI-C-98, Rockwell Hanford Operations, Richland, Washington.

Hal1, R. B. 1991. Letter Report: References for Radioactive Releases to the Columbia River From Hanford Operations, 1944-1957. PNL-7869 HEDR, Pacific Northwest Laboratory, Richland, Washington.

Haney, W. A., ed. 1959. Chemical Effluents Technology Waste Disposal Investigations, July, Auqust, September, 1959. HW-62692-RD, Genera1 Electric Company, Hanford Atomic Products Operation, Richland, Washington.

Haney, W. A., ed. 1960a. Chemical Effluents Technology Waste Disposal Investigations, October, November, December, 1959. HW-64094-RD, General Electric Company, Hanford Atomic Products Operation, Richland, Washington.

Haney, W. A., ed. 1960b. Chemical Effluents Technology Waste Disposal Inves:tigations, April, May, June, 1960. HW-66859-RD, General Electric Company, Hanford Atomic Products Operation, Richland, Washington. 
Haney, W. A., ed. 1960c. Chemical Effluents Technology Waste Disposal Inves:tiqations, July, August, September, 1960. HW-67753-RD, General Electric Company, Hanford Atomic Products Operation, Richland, Washington.

Haney, W. A., ed. 196la. Chemical Effluents Technoiogy Waste Disposal Investigations, October. November, December, 1960. HW-68543-RD, General Electric Company, Hanford Atomic Products Operation, Richland, Washington.

Haney, W. A., ed. 1961b. Chemical Effluents Technology Waste Disposal Investigations, January - June, 1961. HW-70806-RD, General Electric Company, Hanford Atomic Products Operation, Richland, Washington.

Haney, W. A., ed. 1963. Chemical Effluents Technology Waste Disposal Inves. tigations, January - June, 1963. HW-78951, General Electric Company, Hanford Atomic Products Operation, Richland, Washington.

Haney, W. A., D. J. Brown, and A. E. Reisenauer. 1962. Fission Product Tritium in Separations Wastes and in the Ground Water. HW-74536, Gererat Electric Company, Hanford Atomic Products Operation, Richland, Washington.

Healy, J. W. 1948. H. I. "Environs" Report for Month of June 1948.

HW-10427, General Electric Company, Hanford Works, Richland, Washington.

Healy, J. W., and C. C. Gamertsfelder. 1945. Special Studies Branch Report for Weeks Ending May 20, 1945 through December 30, 1945. HW-3-2894, E. I. duPont de Nemours and Company, Hanford Engineer Works, Richland, Washington.

Honstead, J. F., T. H. Essig, and J. K. Soldat. 1967. Evaluation of Radiological Conditions in the Vicinity of Hanford for 1966 . BNWL-439-APP, Pacific Northwest Laboratory, Richland, Washington.

Intercontractor Working Group (IWG). 1987. Data Compilation: Iodine-129 In Hanford Groundwater. WHC-EP-0037, Westinghouse Hanford Company, Richland, Washington.

Jacobson, E. A., and M. D. Freshley. 1990. An Initial Inverse Calibration of the Ground-Water Flow Model for the Hanford Unconfined Aquifer. PNL-7144, Pacific Northwest Laboratory, Richland, Washington.

Jaquish, R. E., and R. W. Bryce. 1989. Hanford Site Environmental Monitoring for CY 1988. PNL-6825, Pacific Northwest Laboratory, Richland, Washington.

Jaquish, R. E., and R. W. Bryce. 1990. Hariford Site Environmental Monitoring for CY 1989. PNL-7346, Pacific Northwest Laboratory, Richland, Washington.

Jaquish, R. E., and P. J. Mitche11. 1988. Environmental Monitoring at Hanford for 1987. PNL-6464, Pacific Northwest Laboratory, Richland, Washington. 
Jensen, E. J. 1987. An Evaluation of Aquifer Intercommunication Between the Unconfined and Rattlesnake Ridge Aquifers on the Hanford Site. PNL-6313, Pacific Northwest Laboratory, Richland, Washington.

Kipp, K. L. 1972. Radiological Status of the Groundwater Beneath the Hanford Project, January - June, 1971. BNWL-1649, Pacific Northwest Laboratory, Richland, Washington.

Kipp, K. L. 1973a. Radiological Status of the Groundwater Beneath the Hanford Project, July - December, 1971. BNWL-1680, Pacific Northwest Laboratory, Richland, Washington.

Kipp, K. L. 1973b. Radiological Status of the Groundwater Beneath the Hanford Project, January - June, 1972. BNWL-1,37, Pacific Northwest Laboratory, Richland, Washington.

Kipp, K. L. 1975. Radiological Status of the Groundwater Beneath the Hanford Reservation, January - December, 1973. BNWL-1860, Pacific Northwest Laboratory, Richland, Washington.

Kipp, K. L., and R. D. Mudd. 1974. Selected Water Table Contour Maps and Wel1 Hydrographs for the Hanford Reservation, 1944-1973. BNWL-B-360, Pacific Northwest Laboratory, Richland, Washington.

Kipp, K. L., A. E. Reisenauer, C. R. Cole, and C. A. Bryan. 1976. Variable Thickness Transient Groundwater Flow Model Theory and Numerical Implementation. BNWL-1703, Pacific Northwest Laboratory, Richland, Washington.

Kirkham, R. R., and G. W. Gee. 1983. "Measurement of Unsaturated Flow Below the Root Zone at an Arid Site." Presented at the National Water Well Association Conference on Characterization and Monitoring of the Vadose Zone, iccember 8-10, Las Vegas, Nevada. PNL-SA-11629, Pacific Northwest Laboratory, Richiand, Washington.

Maas, L. J. 1977. Hanford Sanitary Water Quality Surveillance, cy 1976. Hanford Environmental Health Foundation, Richland, Washington.

Maas, L. J. 1978. Hanford Sanitary Water Quality Surveillance, CY 1977. Hanford Environmental Health Foundation, Richland, Washington.

Maas, L. J. 1979. Hanford Sanitary Water Quality Surveillance, Cy 1978. HEHF-29, Hanford Environmental Health Foundation, Richland, Washington.

McCormack, J. D. 1961. A Sensitive Flowmeter for Measuring Vertical Well Flows. HW-71388, General Electric Hanford Company, Hanford Atomic Products Operation, Richl and, Washington.

McCormack, W. D., and J.M.V. Carlile. 1985. Investigation of Ground-Water Seepage from the Hanford Shoreline of the Columbia River. PNL-5289, Pacific Northwest Laboratory, Richland, Washington. 
McGhan, V. L. 1978. Well Maintenance Evaluation. PNL-2635, Pacific Northwest Laboratory, Richland, Washington.

McGhan, V. L. 1989. Hanford Wells. PNL-6907, Pacific Northwest Laboratory, Richland, Washington.

McGhan, V. L., P. J. Mitchell, and R. S. Argo. 1985. Hanford Wells. PNL-5397, Pacific Northwest Laboratory, Richland, Washington.

Mickelson, M. L. 1952. Annual Report of the Radiological Sciences Department, 1951. HW-25709, General Electric Company, Hanford Works, Richland, Washington.

Myers, D. A. 1978. Environmental Monitoring Report on the Status of Ground Water Beneath the Hanford Site, January - December, 1977. PNL-2624, Pacific Northwest laboratory, Richland, Washington.

Myers, D. A., J. J. Fix, P. J. Blumer, J. R. Rayinond, V. L. McGhan, and E. L. Hilty. No date. Environmental Monitoring Report on the Status of Ground Water Beneath the Hanford Site, January - December 1975. BNWL-2034, Pacific Northwest Laboratory, Richland, Washington.

Myers, D. A., J. J. Fix, and J. R. Raymond. 1977. Environmental Monitoring Report on the Stat lis of Ground Water Beneath the Hanford Site, January December, 1976. B.WWL -2199, Pacific Northwest Laboratory, Richland, Washington.

Napier, B. A. 1991. Selection of Dominant Radionuclides for Phase I of the HEDR Project. PNL-7231 HEDR, Pacific Northwest Laboratory, Richland, Washington.

Napier, B. A., R. A. Peloquin, D. L. Strenge, and J. V. Ramsdell. 1988a. Conceptual Representation. Volume 1 of GENII - The Hanford Environmental Radiation Dosimetry Software System. PNL-6584, Vo1. 1, Pacific Northwest Laboratory, Richland, Washington.

Napier, B. A., R. A. Peloquin, D. L. Strenge, and J. V. Ramsdell. 1988 b. User's Manual. Volume 2 of GENII - The Hanford Environmental Radiation Dosimetry Software System. PNL-6584, Vo1. 2, Pacific Northwest Laboratory, Richland, Washington.

National Council on Radiation Protection and Measurements (NCRP). 1984. Radiological Assessment: Predicting the Transport, Bioaccumulation, and Uptake by Man of Radionuclides Released to the Environment. NCRP Report No. 76, National Council on Radiation Protection and Measurements, Bethesda, Maryland.

Nelson, R. W. 1964. Analysis of Waste Released by Seepage to the Columbia River from the $1301-\mathrm{N}$ Crib. HW-81306, General Electric Company, Hanford Atomic Products Operation, Richland, Washington. 
Newcomb, R. C., and J. R. Strand. 1953. Geology and Ground-Water Characteristics of the Hanford Reservation of the Atomic Energy Commission.

USGS-WP-8, U.S. Department of the Interior, Geological Survey, Washington, D.C.

Newcomb, R. C., J. R. Strand, and F. J. Frank. 1972. Geology and GroundWater Characteristics of the Hanford Reservation of the U.S. Atomic Energy Commission. Washinaton. U.S. Geological Survey Professional Paper 717, U.S. Government Printing Office, Washington, D.C.

Newcomer, D. R. 1990. Evaluation of Hanford Site Water-Table Changes - 1980 to 1990. PNL-7498, Pacific Northwest Laboratory, Richland, Washington.

Paas, H. J. 1951a. Radioactive Contamination in the Environs of the Hanford Works for the Period October, November, December 1950. Hit-21566, General Electric Company, Hanford Works, Richland, Washington.

Paas, H. J. 1951b. Radioactive Contamination in the Environs of the Hanford Works and Vicinity for the Period April, May, June 1951. HW-22313, General Electric Company, Hanford Works, Richland, Washington.

Paas, H. J. 1951c. Radioactive Contamination in the Environs of the Hanford Works and Vicinity for the Period July. Auqust, September 1951. HW-23133, General Electric Company, Hanford Works, Richland, Washington.

Paas, H. J. 1952a. Radioactive Contamination in the Environs of the Hanford Works for the Period October, November, December 1951. HW-24203, General Electric Company, Hanford Works, Richland, Washington.

Paas, H. J. 1952b. Radioactive Contamination in the Environs of the Hanford Works for the Period January, February, March, 1952. HW-25866, General Electric Company, Hanford Works, RichTand, Washington.

Paas, H. J. 1952c. Radioactive Contamination in the Environs of the Hanford Works for the Period Apri1, May, June, 1952. HW-26493, General Electric Company, Hanford Works, Richland, Washington.

Paas, H. J. 1953a. Radioactive Contamination in the Environs of the Hanford Works for the Period July, Auqust, September 1952. HW-27510, General Electric Company, Hanford Atomic Products Operation, Richiand, Washington.

Paas, H. J. 1953b. Radioactive Contamination in the Environs of the Hanford Works for the Period October, November, December 1952. HW-27641, General Electric Company, Hanford Atomic Products Operation, Richland, Washington.

Paas, H. J. 1953c. Radioactive Contamination in the Environs of the Hanford Works for the Period January, February, March 1953. HW-28009, General Electric Company, Hanford Atomic Products Operation, Richland, Washington. 
Paas, H. J. 1953d. Radioactive Contamination in the Environs of the Hanford Works for the Period April. May, June 1953. HW-29514, General Electric Company, Hanford Atomic Products Operation, Richland, Washington.

Paas, H. J. 1953e. Radioactive Contamination in the Environs of the Hanford Works and Vicinity for the Period July, August, September 1953. HW-30174, General Electric Company, Hanford Atomic Products Operation, Richland, Washington.

Paas, H. J., and K. R. Heid. 1955. Radioactive Contamination in Liquid Wastes Discharged to Ground at Separation Facilities Through June 1955. HW-38562, General Electric Company, Hanford Atomic Products Operation, Richland, Washington.

Paas, H. J., and W. Singlevich. 1950a. Radioactive Contamination in the Environs of the Hanford Works for the Period April, May, June 1949.

HW-17434 DEL, General Electric Company, Hanford Works, Richland, Washington.

Paas, H. J., and W. Singlevich. 1950b. Radioactive Contamination in the Environs of the Hanford Works for the Period July, Auqust, September 1949. HW-18615, General Electric Company, Hanford Works, Richland, Washington.

Paas, H. J., and W. Singlevich. 1950c. Radioactive Contamination in the Environs of the Hanford Works for the Period January, February, March 1950. HW-18446, General Electric Company, Hanford Works, Richland, Washington.

Paas, H. J., and W. Singlevich. 1950d. Radioactive Contamination in the Environs of the Hanford Works for the Period April, May, June 1950. HW-19454, General Electric Company, Hanford Works, Richland, Washington.

Pacific Northwest Laboratory (PNL). 1987. Environmental Monitoring at Hanford for 1986. PNL-6120, Pacific Northwest Laboratory, Richland, Washington.

Pacific Northwest Laboratory (PNL). 1991a. Summary Report: Phase I of the Hanford Environmental Dose Reconstruction Project. PNL-7410 HEDR Rev. 1, Pacific Northwest Laboratory, Richland, Washington.

Pacific Northwest Laboratory (PNL). 1991b. Columbia River Pathway Report: Phase I of the Hanford Environmental Dose Reconstruction Project. PNL-7411 HEDR Rev. 1, Pacific Northwest Laboratory, Richland, Washington.

Pacific Northwest Laboratory (PNL). 1991c. Air Pathway Report: Phase I of the Hanford Environmental Dose Reconstruction Project. PNL-7412 HEDR Rev. 1, Pacific Northwest Laboratory, Richland, Washington.

Pacific Northwest Laboratory (PNL). 1991d. FY 1992 Task Plans for the Hanford Environmental Dose Reconstruction Project. PNL-7757 HEDR, Pacific Northwest Laboratory, Ricinland, Washington. 
Parker, G. G., and A. M. Piper. 1949. Geologic and Hydrologic Features of the Richland Area, Washington, Relevant to Disposal of Waste at the Hanford Operations Office of the Atomic Energy Commission. USGS-WP.7, U.S. Department of the Interior, Geological Survey, Washington, D.C.

Parker, H. M. 1945. Monthly Reports - Health Instrument Section - for 1945. HW-7-1228, E. I. duPont de Nemours and Company, Hanford Engineer Works, Richland, Washington.

Parker, H. M. 1946a. H. I. Section Report for September 1946. HW-7-5145, E. I. duPont de Nemours and Company, Hanford Engineer Works, Richland, Washington.

Parker, H. M. 1946b. H. I. Section Report for October 1946. HW-7-5301, General Electric Company, Hanford Works, Richland, Washington.

Parker, H. M. 1946c. H. I. Section Report for November 1946. HW-7-5428, General Electric Company, Hanford Works, Richland, Washington.

Parker, H. M. 1946d. H. I. Section Report for December 1946. HW-7-5605, General Electric Company, Hanford Works, Richland, Washington.

Parker, H. M. 1947a. H. I. Section Report for January 1947. HW-7-5760, General Electric Company, Hanford Works, Richland, Washington.

Parker, H. M. 1947b. H. I. Section Report for May 1947. HW-7-6392, General Electric Company, Hanford Works, Richland, Washington.

Parker, H. M. 1954. Ground Disposal of Radioactive Wastes at the Hanford Site. HW-32041, General Electric Company, Hanford Atomic Products Operation, Richl and, Washington.

Parker, H. M. 1956. Radiological Sciences Department Quarterly Progress Report, Research and Development Activities, January - March, 1956. HW-42403, General Electric Company, Hanford Atomic Products Operation, Richland, Washington.

Parker, H. M., and C. C. Gamertsfelder. 1945a. Weekly H. I. Reports on 200 Area and Environs for 1-5-45 Through 2-13-46 (\#1 Through 58). HW-7-1115, E. I. duPont de Nemours and Company, Hanford Engineer Works, Richland, Washington.

Parker, H. M., and C. C. Gamertsfelder. 1945b. Weekly H. I. Reports on the 100-Areas and 300-Area, \#1 Through 35 (5-5-45 Through 12-31-45). HW-7-1635, E. I. duPont de Nemours and Company, Hanford Engineer Works, Richland, Washington.

Prater, L. S., J. T. Rieger, C. S. Cline, E. J. Jensen, T. L. Liikala, and K. R. Oster. 1984. Ground-Water Surveillance at the Hanford Site for CY-1983. PNL-5041, Pacific Northwest Laboratory, Richland, Washington. 
Price, K. R., ed. 1986. Environmental Monitoring at Hanford for 1985. PNL-5817, Pacific Northwest Laboratory, Richland, Washington.

Raymond, J. R. 1955. An Electrical Technique for Ground Water Velocity Measurement. HW-36217, General ETectric Company, Hanford Atomic Products Operstion, Richland, Washington.

Raymond, J. R. 1958. A Shaped Charge System for Well Casing Perforating. HW-57675, General Electric Company, Hanforú Atomic Products Operation, Richland, Washington.

Raymond, J. R. 1960. "Equipment and Methods for Ground-Water Investigation at Hanford." In Proceedings of Northwest Scientific Association, Moscow, Idaho.

Raymond, J. R., and V. L. Mclihar. 1964. Scintillation Probe Results $=200$ Area Waste Disposal Site Monitorina Wells. HW-84577, Geneidi Electric Company, Hanford Atomic Products Operation, Richland, Washington.

Raymond, J. R., D. A. Myers, J. J. Fix, V. L. McGhan, and P. M. Schrotke, 1976. Environmental Monitoring Report on Radiological status of the fround Water Beneath the Hanford Site january - December 1974. BNWL-1970, Pacific Northwest Laboratory, Richland, Washington.

Routson, R. C. 1973. A Review of Soll-Waste Relationshios on the Hanford Reservation from 1944 to 1967. BNWL-1464, Pacifir. Northwest Laboratory, Richland, Washington.

Ruppert, H. G., and K. R. Heid. 1954. Summary of Liquid Radioactive Wastes Discharged to the Ground - 200 Areas, July 1952 Through June 1954. HW.33591, General Electric Company, Hanford Atomic Products Operation, Richland, Washington.

Schwab, G. E., R. M. Colpitts, Jr., and D. A. Schwab. 1979. Spring Inventory of the Rattlesnake Hills. RHO-BWI-C-47, Rockwell Hanford Operations, Richland, Wastington.

Serkowski, J. A., and W. A. Jordan. 1989. Operational Groundwater Monitoring at the Hanford Site, 1988. WHC-EP-0260, Westinghouse Hanford Company, Richland, Washington.

Seymour, F. P. 1946. A Study of Total Amounts of Active Waste Released in All Manners by the $H$. E. W. Process to Date. HW-7-5463, E. I. duPont de Nemours and Company, Hanford Engineer Works, Richland, Washington.

Singlevich, W. 1948\%. H. I. "Environs" Report for Month of January 1948. HW-8783, General Electric Company, Hanford Works, Richland, Washington.

Singlevich, W. 1348b. H. I. "Environs" Report for Month of February 1948. HW-9103, General Electric Company, Hanford Works, Richland, Washington. 
Sing:evich, W. 1948c. H. I. "Environs" Report for Month of March 1948. HW-95n), General Electric Company, Hanford Works, Richland, Washington.

singlev ch, W. 1948d. H. I. "Environs" Report for Month of April 1948. HW-9730, General Electric Company, Hanford Works, Richland, Washington.

Singlevich, W. 1948e. H. I. "Environs" Report for Month of May 1948. HW-10049, General Electric Company, Hanford Works, Richland, Washington.

Singlevich, W. 1948f. H. 1. "Environs" Report for Month of July 1948. HW-10730, General Electric Company, Hanford Works, Richland, Washington.

Singlevich, W. 1948g. H. I. "Environs" Report for Month of Auqust 1948. 4H-10998, General Electric Company, Hanfori Works, Richiand, Washington.

Singlevich, W. 1948h. Radioactive Contamination in the Environs of the Hanford Works and Vicinity for ihe Perind January. February. March 1948. HW-10242 DEL, General ETectric Company, Hanford Works, Fichland, Washington.

Singlevich, W. 1948i. Radioactive Comtamination in the Environs of the Hanford Works and Vicinity for the Period April, May, June 1948. HW-11333 DEL, General Eleciric Company, Hanford Works, Richland, Washington.

Singlevich, W., and J. J. Paas, 1949a. Radioactive Contamination in the Environs of the Hanford Works and Vicinity for the Period October, November, December 1948. HW-13743, General Electric Company, Hanford Works, Richland, Washington.

Singlevich, W., and J. J. Paas. 1949b. Radioactive Contamination in the Environs of the Hanford Works and Vicinity for the Period January. February, March 1949. HW-1424.3 DEL, General Electric Company, Hanford Works, Richland, Washington.

Smoot, J. L., and B. Sagar. 1990. Three-Dimensional Contaminant Plume Dynamics in the Vadose Zone: Simulation of the 241-T-106 Single-Shell Tank Leak at Hanford. PNL-7721, Pacific Northwest Laboratory, Richland, Washington.

Somers, S. R. 1987. Hanford Sanitary Water Quality Surveillance, CY 1986. HEHF-59, Hanford Environmental Health Foundation, Richland, Washington.

Somers, S. R. 1988. Hanford Sanitary Water Quality Surveillance, ry 1987. HEHF-71, Hanford Environimental Health Foundation, Richland, Washington.

Stenner, R. D., K. H. Cramer, K. A. Higley, S. J. Jette, D. A. Lamar, T. J. Mclaughi in, D. R. Sherwood, and N. C. Van Houten. 1988. Hazard Ranking System Evaluation of CERCLA Inactive Waste Sites at Hanford. PNL-6456, Yo1. 1-2, Pacific Northwest Laboratory, Richiand, Washington. 
Tallman, A. M., K. R. Fecht, M. C. Marratt, and G. V. Last. 1979. Geology of the Separation Areas, Hanford Site, South-Central Washington. RHO-ST-23, Rockwe 11 Hanford Operations, Richland, Washington.

Thurman, P. A. 1990. Hanford Sanitary Water Quality Surveillance, CY 1989. HEHF-76, Hanford Environmental Health Foundation, Richland, Washington.

U.S. Department of Energy (DOE). 1987. Einal Environmental Impact Statement, Disposal of Hanford Defense High-Level, Transuranic and Tank Wastes. DOE/EIS0113 , Department of Energy, Washington, D.C.

U.S. Department of Energy (DOE). 1988. Consultation Draft Site Characterization Plan, Reference Repository Location. Hanford Site, Washington, $V_{0 l} .2$. DOE/RW-0164, Vo7. 2 of 9. U.S. Department of Energy, Office of Civilian Radioactive Waste Management, Washington, O.C.

U.S. Environmental Protection Agency (EPA). 1976. National Interim Primary Drinking Water Regulations. EPA-570/9-76-003, Uffice of Water Supply, Washington, D.C.

U.S. Geological Survey (USGS). 1987. Subsurface Transport of Radionuclides in Shallow Deposits of the Hanford Nuclear Reservation. Washington - Review of Selected Previous Work and Sugcestions for Further Study. Open-File Report 87-222, U.S. Department of the Interior, U.S. Geological Survey, Denver, Colorado.

Washington Department of Social and Health Services (WDSHS). 1988. Investigation Report: Radiological Evaluation of Well Water in Franklin County. EPS-87-367A, State of Washington, Department of Social and Health Services, Olympia, Washington.

Wilson, R. H., and R. F. Foster. 1964. Evaluation of Radiological Conditions in the Vicinity of Hanford for 1963. HW-80991, General Electric Company, Hanford Atomic Products Operation, General Electric Company, Richland, Washington.

Woodruff, R. K., R. W. Hanf, M. G. Hefty, and R. G. Lundren. 1991. Hanford Site Environmental Report for Calendar Year 1990. PNL-7930, Pacific Northwest Laboratory, Richland, Washington.

Zimmerman, D. A., A. E. Reisenauer, G. D. Black, and M. A. Young. 1986. Hanford Site Water Table Changes 1950 Through 1980 - Data Observations and Evaluation. PNL-5506, Pacific Northwest Laboratory, Richland, Washington. 
APPENDIX A

TSP DIRECTIVE 88-4 
Technical Steering Panel

Hanford Environmental Dose

Roconstruction Project

P. O. Box 1734

Richland, Washington 99352

\section{TECHNICAL STEERING PANEL RESEARCH DIRECTIVE}

Directive Number:

Date:

Subject:
88-4

November 23, 1988

\section{Action to be Taken:}

The TSP recommends that three activities be carried out by Battelle in their ground water transport subtask. These activities should be carried out immediately.

1. (a) List all wells on and adjacent to the Hanford Reservation which may have supplied ground water (for irrigation or domestic use) which was contaminated by radionuclides originating on the Hanford Reservation.

(b) Make estimates of the level of contamination and the number of people affected.

2. Make some reasonable estimates of the location and number of irrigation and municipal supply wells which are near enough to the Columbia River to have been affected significantly by radionuclides discharged into the river by operations at Hanford.

3. Make an estimate of the radionuclides discharged into the Columbia River by unconfined ground water flow which originates in the 200 Area and seeps southward into the river.

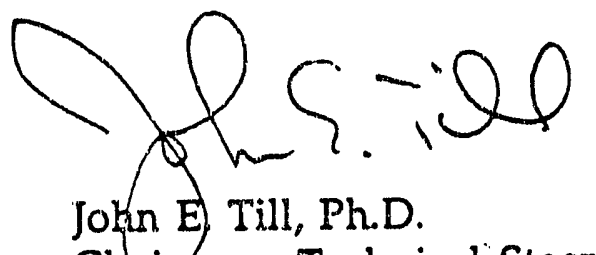

Chairman, Technical Steering Panel 


\section{APPENDIX B}

SUMMARY OF SANITARY-WATER SYSTEMS AT THE HANFORD SITE 
TABLE B.1. Sanitary-Water Systems at the Hanford Site (after Thurman. 1990)

System Name

$182-B$

$100-D$

$100-K$

$100-\mathrm{N}$

$200-E / 200-W$

251 Building

609 Building

$622-R$

Yakima Barricade

$6652-C$ (PNL

Observatory)

Patrol Training Academy

400 Area (FFTF)

300 Area

Richl and
Source of Supply

Columbia River

Columbia River

Columbia River

Columbia River

Columbia River

Columbia River

Columbia River

Columbia River

We11 699-49100-C

Developed Spring at $3160 \mathrm{ft}$ on Rattiesriake Mountain

We11 699-S28-EO

Welis 499-S1-8J and 499-SO-7

Columbia River

Columbia River and ground water
Notes

Filtered and chiorinated

Filtered and chlorinated

Filtered and chlorinated

Filtered and chlorinated

Filtered and chlorinated

Filtered and chlorinated

Filtered and chlorinated

Filtered and chlorinated

No treatment provided

Chlorination only

Chlorination only

Supplies mixed: $93 \%$ from S1-8J and 7\% from S0-7; chlorination only

Filtered and chlorinated

River water filtered and chlorinated; ground water chlorinated only

B. 1 
APPENDIX C

COMMUNITIES WHOSE DRINKING WATER MAY HAVE COME FROM

RIPARIAN WELLS DOWNSTREAM OF HANFORD 


\section{COMMUNITIES WHOSE DRINKING WATER MAY HAVE COME FROM RIPARIAN WELLS DOWNSTREAM OF HANFORD}

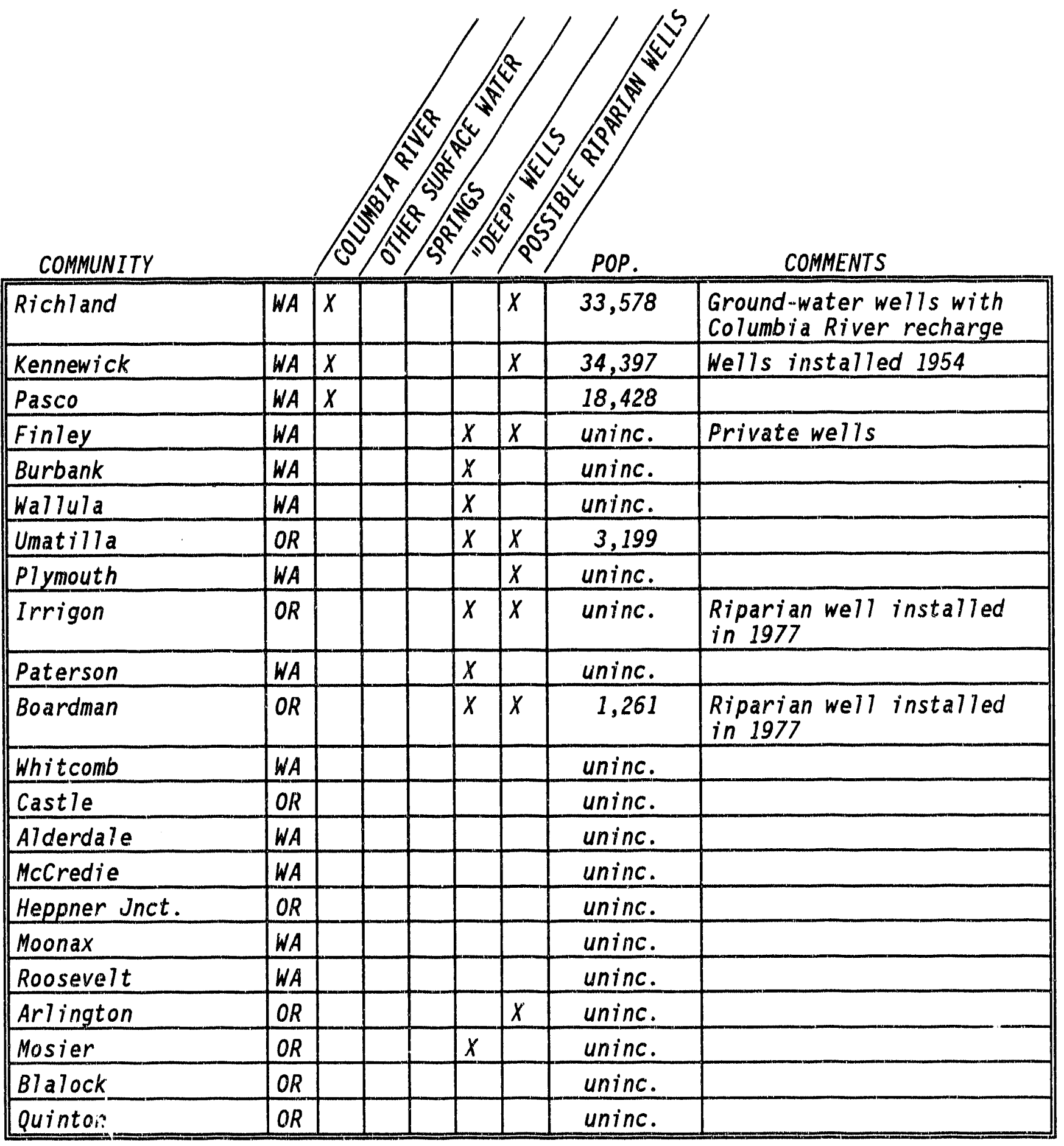




\begin{tabular}{|c|c|c|c|c|c|c|c|}
\hline COMMUNITY & & & & & & POP. & COMMENTS \\
\hline Hook & $O R$ & & & & & uninc. & \\
\hline Cliffs & $W A$ & & & & & uninc. & \\
\hline Rufus & $O R$ & & & $x$ & & uninc. & $\begin{array}{l}250 \text { and } 272 \mathrm{ft} \text {. deep } \\
\text { well s near river }\end{array}$ \\
\hline Maryhill & $W A$ & & & & $x$ & uninc. & \\
\hline Biggs & $O R$ & & & & & uninc. & \\
\hline Miller & $O R$ & & & & & uninc. & \\
\hline Moody & $O R$ & & & & & uninc. & \\
\hline Wishram & $W A$ & $x$ & $x$ & & $x$ & uninc. & \\
\hline Celito & $O R$ & & & & & uninc. & \\
\hline The Dalles & OR & $x$ & & $x$ & & 10,820 & $90 \%$ surface source \\
\hline Dallesport & WA & & & & & uninc. & - \\
\hline Crates & $O R$ & & & & & uninc: & \\
\hline Murdock & WA & & & & & uninc. & \\
\hline Rowena & OR & & & & & uninc. & \\
\hline Lyle & WA & $x$ & $x$ & & $x$ & uninc. & \\
\hline Mosier & $O R$ & & & $x$ & & uninc. & \\
\hline Bingen & WA & & & $x$ & & 679 & \\
\hline White Salmon & WA & $x$ & & & & 1,853 & \\
\hline Hood River & $O R$ & & $x$ & & & 4,370 & \\
\hline Underwood & WA & & $x$ & & & uninc. & \\
\hline Hood & WA & & & & & uninc. & \\
\hline Viento & $O R$ & & & & & uninc. & \\
\hline Cook & $W A$ & & $x$ & & & uninc. & \\
\hline Wyeth & OR & & & & & uninc. & \\
\hline Home Valley & WA & & & & & uninc. & \\
\hline
\end{tabular}




\begin{tabular}{|c|c|c|c|c|c|c|c|}
\hline COMMUNITY & & & & & & POP. & COMMENTS \\
\hline Carson & $W A$ & & & & $x$ & uninc. & \\
\hline Stevenson & $W A$ & $\underline{x}$ & & & & 1,172 & \\
\hline Cascade Locks & $O R$ & $x$ & & & $x$ & uninc. & \\
\hline N. Bonneville & $W A$ & $x$ & & & $x$ & 431 & \\
\hline Bonnevilie & $O R$ & & & & & uninc. & \\
\hline Skamania & $W A$ & & & & $x$ & uninc. & \\
\hline Multnoma Falls & $O R$ & & & & & uninc. & \\
\hline Bridal Veil & $O R$ & & & & & uninc. & \\
\hline Latourell Falls & $O R$ & & & & & uninc. & \\
\hline Mt. Pleasant & $W A$ & & & & & uninc. & \\
\hline Corbett & $O R$ & & & & & uninc. & \\
\hline Washougal & $W A$ & & & & $x$ & 3,834 & \\
\hline Camas & $W A$ & & & & $x$ & 5,681 & \\
\hline Fairview & $O R$ & & & $x$ & & uninc. & \\
\hline Portland & $O R$ & $x$ & & & $x$ & 379,967 & $\begin{array}{l}<5 \% \text { from wells } \\
\text { beginning in } 1986\end{array}$ \\
\hline Vancouver & $W A$ & & $x$ & $x$ & & 42,834 & \\
\hline Ridgefield & $W A$ & & & & $x$ & 1,195 & \\
\hline Warren & WA & & & & $x$ & uninc. & \\
\hline St. Helens & $O R$ & & & & $x$ & 6,212 & Infiltration trench \\
\hline Columbia City & $O R$ & & & & $x$ & 678 & Infiltration trench \\
\hline Deer I sland & $O R$ & & & & $x$ & unine. & \\
\hline Kalama & $W A$ & $x$ & & & & 1,216 & \\
\hline Gobel & $O R$ & & & & $x$ & uninc. & \\
\hline Prescott & $O R$ & & & & & uninc. & \\
\hline
\end{tabular}




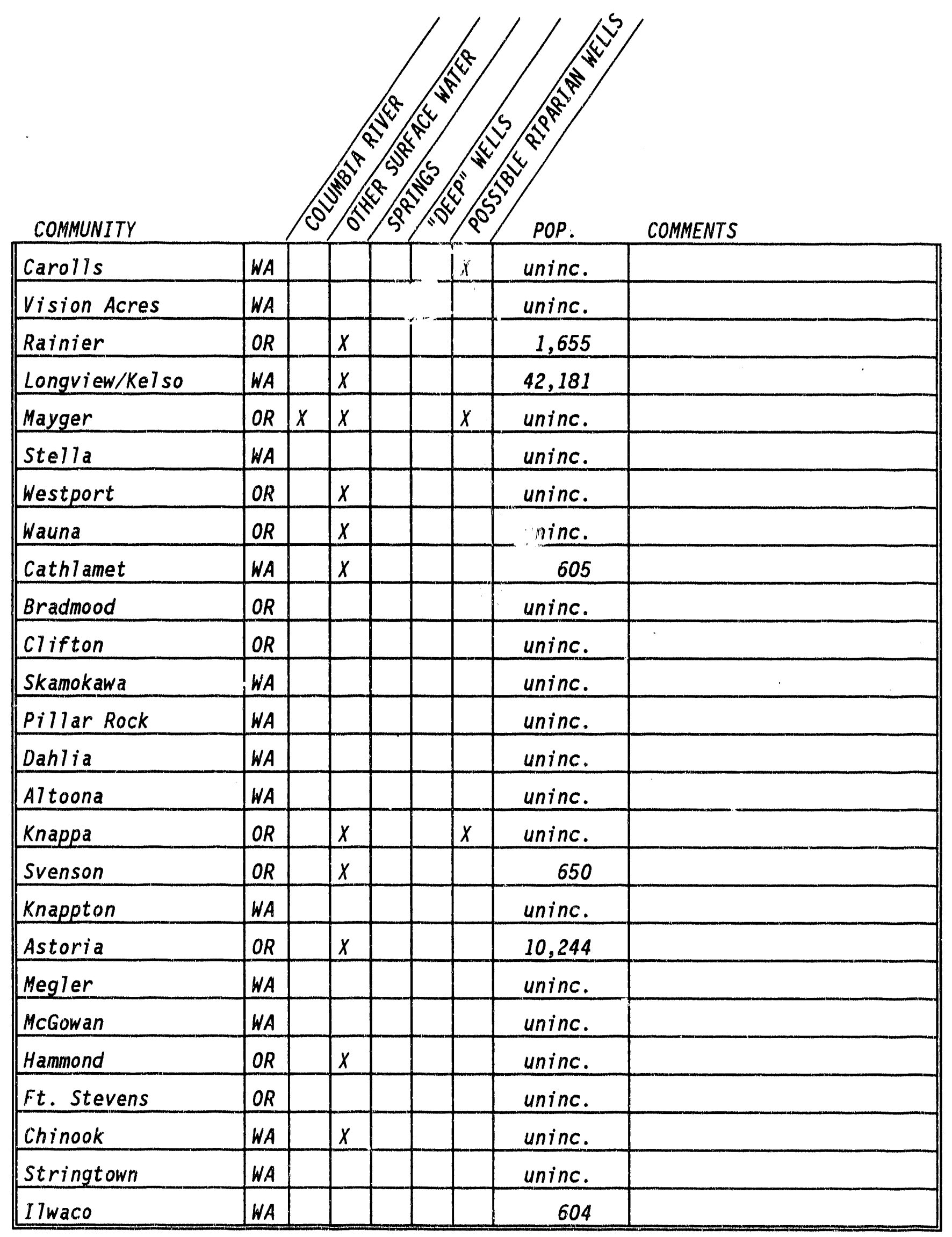


APPENDIX D

GLOSSARY 
APPENDIX D

GLOSSARY

Alpha Radiation - Least penetrating type of radiation. Alpha radiation can be stopped by a sheet of paper or the outer dead layer of skin.

Fquifer - Saturated geologic unit that can transmit significant quantities of water.

Background Radiation - Radioactivity in the environment, including cosmic rays from space and radiation that exists elsewhere in the air, in the earth. and in manmade materials that surround us. In the United States, the average person receives about 300 millirems (mrem) of background radiation per year.

Bank Storage - Hydrologic term describing river water that filows into and is retained in permeable stream banks during periods of high river stage. Flow is reversed during periods of low river stage.

Beta Radiation - One form of radiation emitted from a nucleus during radioactive decay. Beta radiation can be stopped by an inch of wood or a thin sheet of aluminum.

Composite Sample - Sample formed by mixing discrete samples taken at different points in time.

Confined Aquifer - An aquifer bounded above and below by less permeable layers. Ground water in the confined aquifer is under a pressure greater than atmospheric pressure.

Continuous Sample - Sample formed by the continuous collection of the media or contaminants within the media during the entire sample period.

Curie (Ci) - A unit of radioactivity equal to 37 billion $\left(3.7 \times 10^{10}\right)$ nuclear disintegrations per second.

Decay, Radioactive - The process by which a radioactive nucleus spontaneously changes into the nucleus of a different element, which may be radioactive or stable.

Deposition - Process through which material in the air settles to the ground.

Detection Limit - Minimum concentration of a substance that can be measured with $99 \%$ confidence that the analytical concentration is greater than zero.

Dispersion - Process whereby effluents are spread or mixed as they are transported by ground water.

D.1 
Drinking-Water Standard - A maximum concentration limit established by the U.S. Environmental Protection Agency for radionuclides in public drinkingwater supplies.

Effective Dose - See "Effective Dose Equivalent."

Effective Dose Equivalent - An estimate of the total risk of potential health effects from radiation exposure. This estimate is the sum of the committed effective dose equivalent from internal deposition and the effective dose equivalent from external penetrating radiation received during a calendar year.

Effluent - Liquid waste streams released to the environment from a facility.

Effluent Monitoring - Sampling or measuring specific liquid effluent streams for the presence of pollutants.

Exposure - Subjecting a target (usually living tissue) to radiation or chemicals.

External Radiation - Radiation originating from a source outside the body, such as cosmic radiation or natural and manmade radionuclides.

Fallout - Radioactive materials mixed into the earth's atmosphere following a nuclear explosion. Fallout from past testing is suspended in the atmosphere and precipitates onto the earth.

Fission (fissioned) - Splitting a nucleus into at least two other nuclei.

Fission Products - Elements or compourds formed from fissioning. Many fission products are radioactive.

Gamma Radiation - Form of electromagnetic, high-energy radiation emitted from a nucleus. Gamma rays are essentially the same as $X$ rays and require heavy shielring, such as concrete or steel, to be stopped.

Grat Sample - Individual discrete sample collected over a short period of time:

96 Gross-Alpha - The total alpha radiation (helium nuclei) emitted by a unit mass or volume of material containing radionuclides.

Ground Water - Subsurface water that is in the pore spaces of saturated soil and geologic units.

Gross-Beta - The total beta radiation (electrons and positrons) emitted by a unit mass or volume of material containing radionuclides.

Half-Life - Length of time in which a radioactive substance will lose one-half of its radioactivity through radioactive decay. 
Hydraulic Conductivity - A parameter that quantifies the ability of a porous media to transmit water.

Infiltration - The rate at which water on the surface flows into the soil.

Isopleth - A line of equal concentration of a dissolved chemical species.

Isotopes - Different forms of the same chemical element that are distinguished by different numbers of neutrons in the nucleus.

Mean - Average value of a series of measurements.

Median - Middle value in a set of results when the data are ranked in increasing or decreasing order.

Millirem (mrem) - A unit of radiation dose equivalent that is equal to one one-thousandth of a rem.

Minimum Detectable Concentration - see detection limit.

Plume - Distribution of a pollutant in air, soil, ground water, or surface water after being released from a source.

PUREX - Plutonium, uranium extraction (process).

Radiation - Energy emitted in the form of rays or particles such as those thrown off by disintegrating atoms. The rays or particles emitted may consist of alpha, beta, or gamma radiation.

Radioactivity - Property possessed by some elements, such as uranium, whereby alpha, beta, or gamma rays are spontaneously emitted.

Radioisotope - Radioactive isotope of a specified element. Carbon-14 is a radioisotope of carbon. Tritium is a radioisotope of hydrogen.

Radionuclide - Radioactive nuclide. There are several hundred known radioactive nuclides, both manmade and naturally occurring. Nuclides are characterized by the number of neutrons and protons in an atom's nucleus.

Rem - Acronym for Roentgen Equivalent Man; a unit of dose equivalent that indicates the potential impact on human cells.

Riparian Well - Well, all or part of whose water comes indirectly from a nearby river or stream.

Sorption - The reversible attachment of charged, dissolved particles to the surface of solid materials.

Spent Fuel - Nuclear fuel that has been irradiated in a nuclear reactor; this fuel contains uranium, activation products, fission products, and plutonium. At Hanford, spent fuel is processed in the PUREX Plant. 
Travel Time - The time required for ground water, surface water, or a dissolved substance in either media, to move from one point to another in an aquifer or stream.

Unconfined Aquifer - An aquifer containing ground water that is not confined above by relatively impermeable rocks. The pressure at the top of the unconfined aquifer is equal to that of the atmosphere. At Hanford, the unconfined aquifer is the uppermost aquifer and is most susceptible to contamination from Site operations.

Water Table - Theoretical surface represented by the elevation of water surfaces in wells penetrating only a short distance into the unconfined aquifer.

Watershed - An area, delineated by a drainage divide, in which surface runoff and shallow ground water flow into a common watercourse. 
APPENDIX E

SUMMARY OF THE TECHNICAL STEERING PANEL'S COMMENTS

AND BATTELLLE'S RESPONSES 


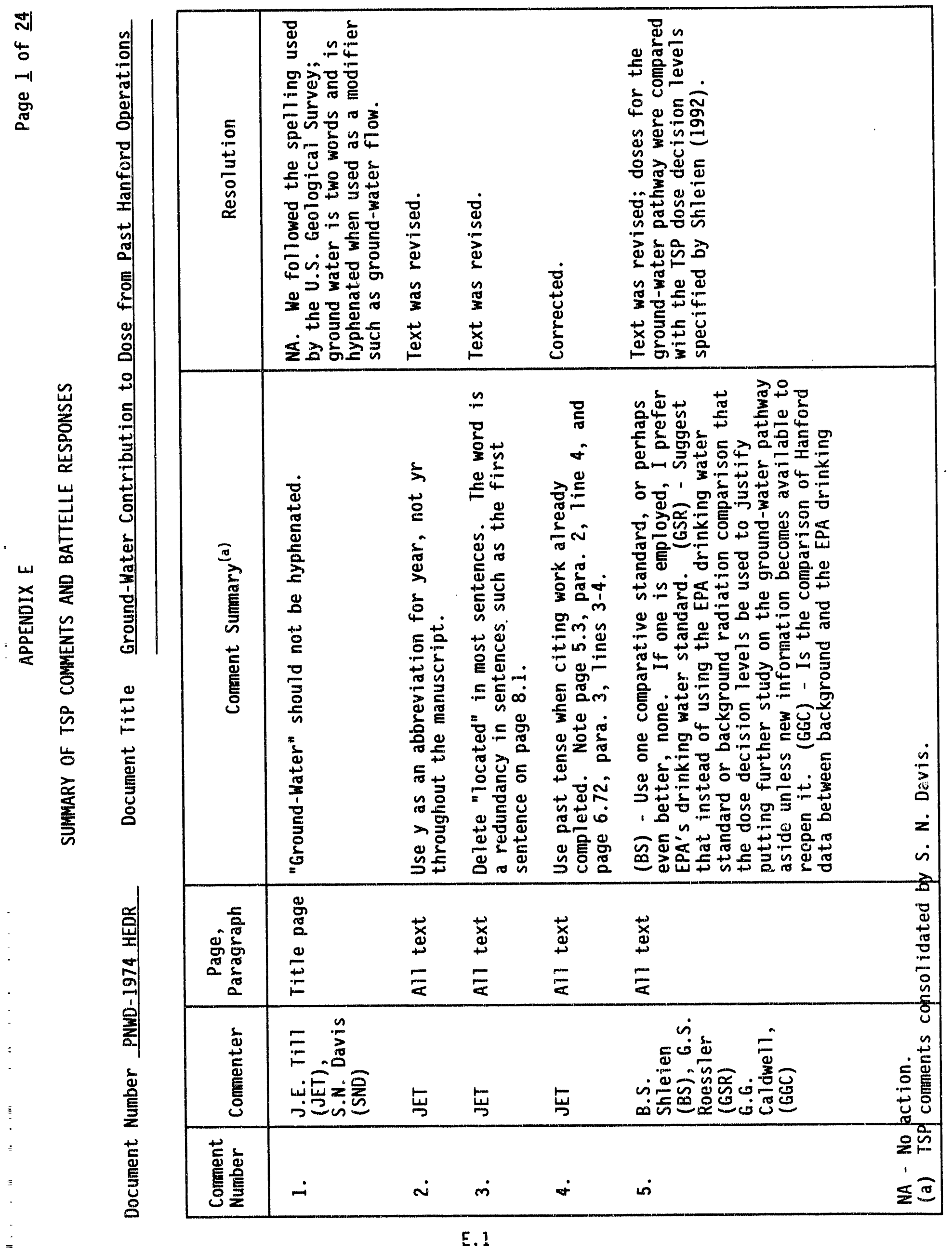




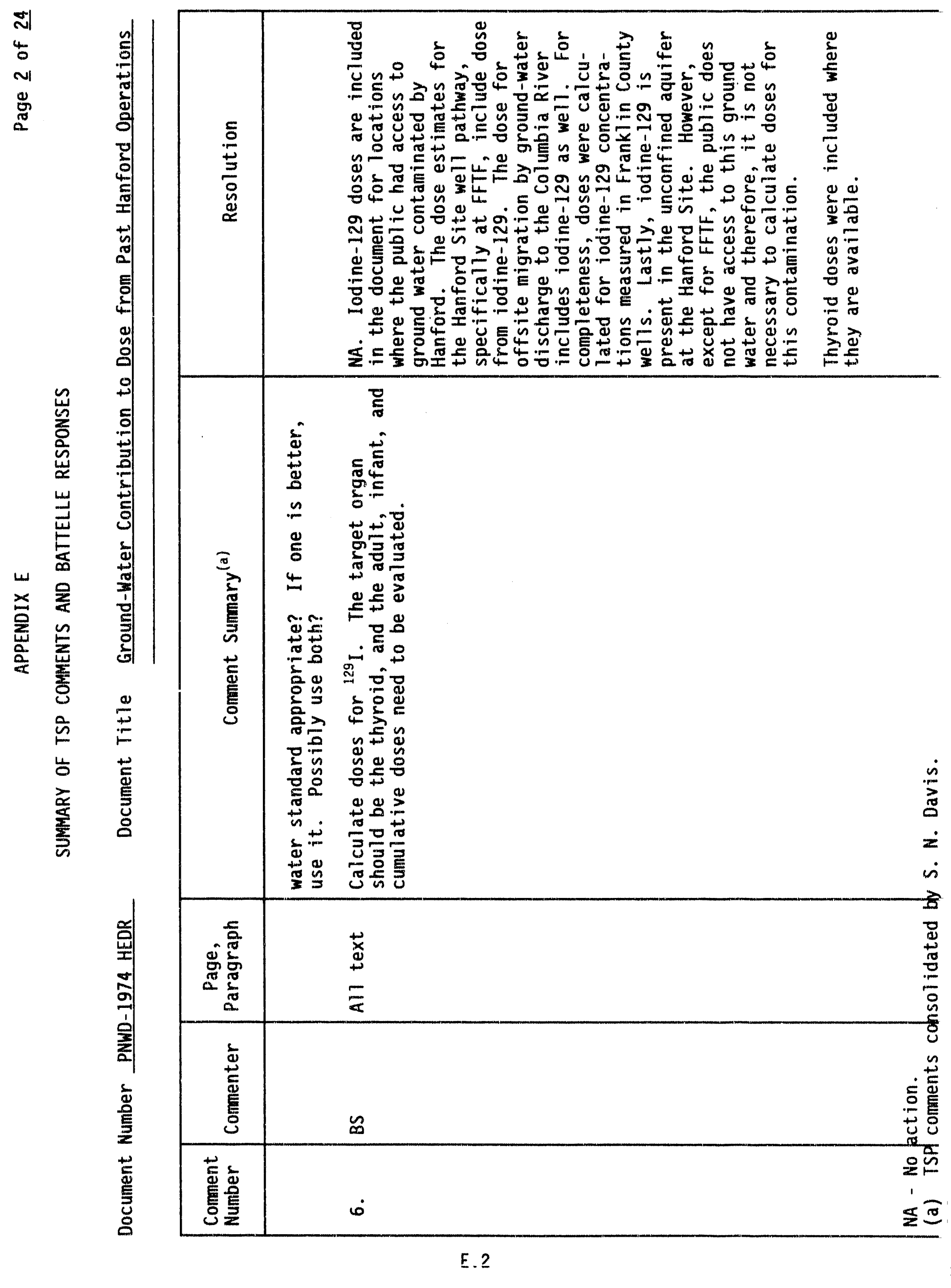




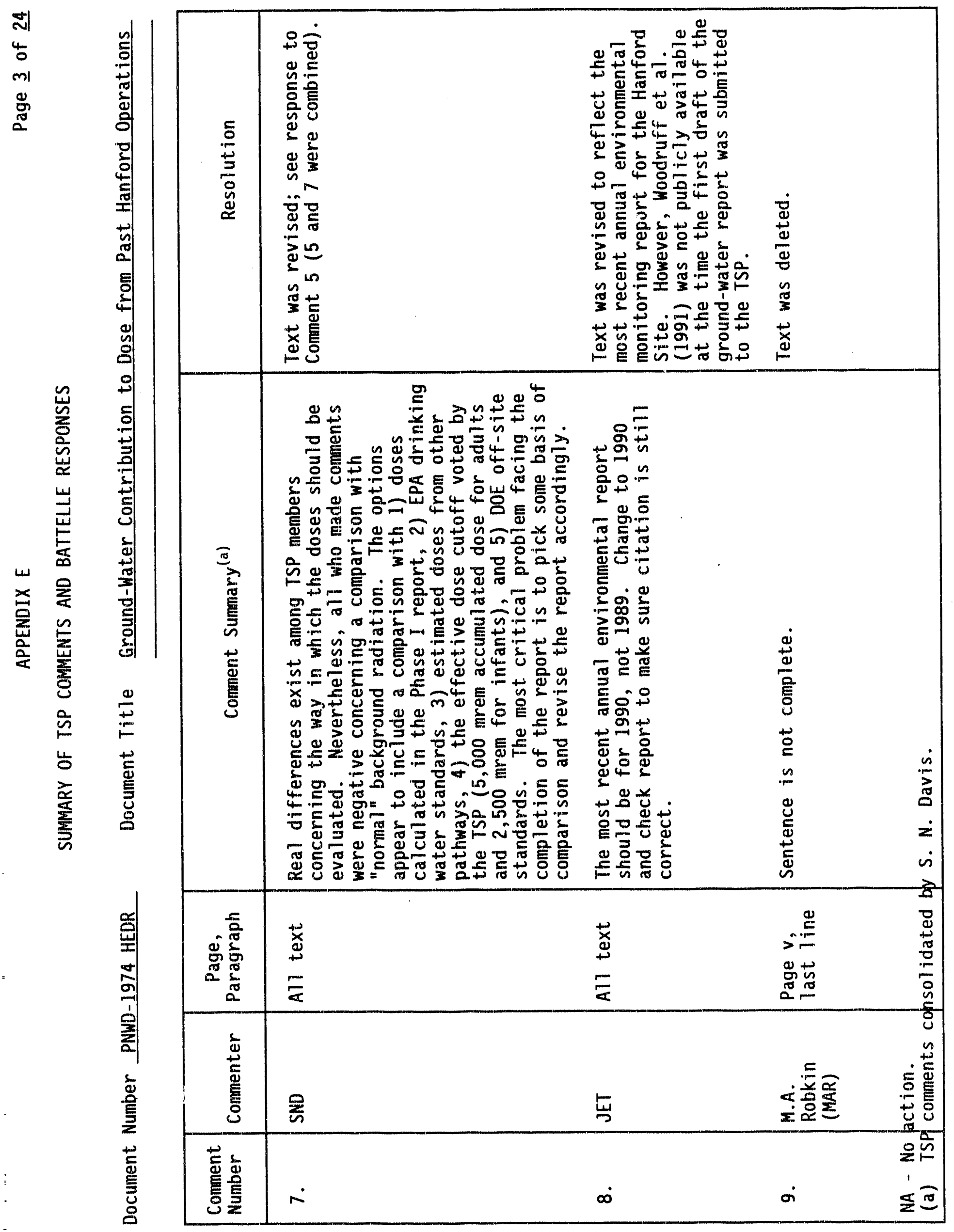


N
4
0
0
0
0

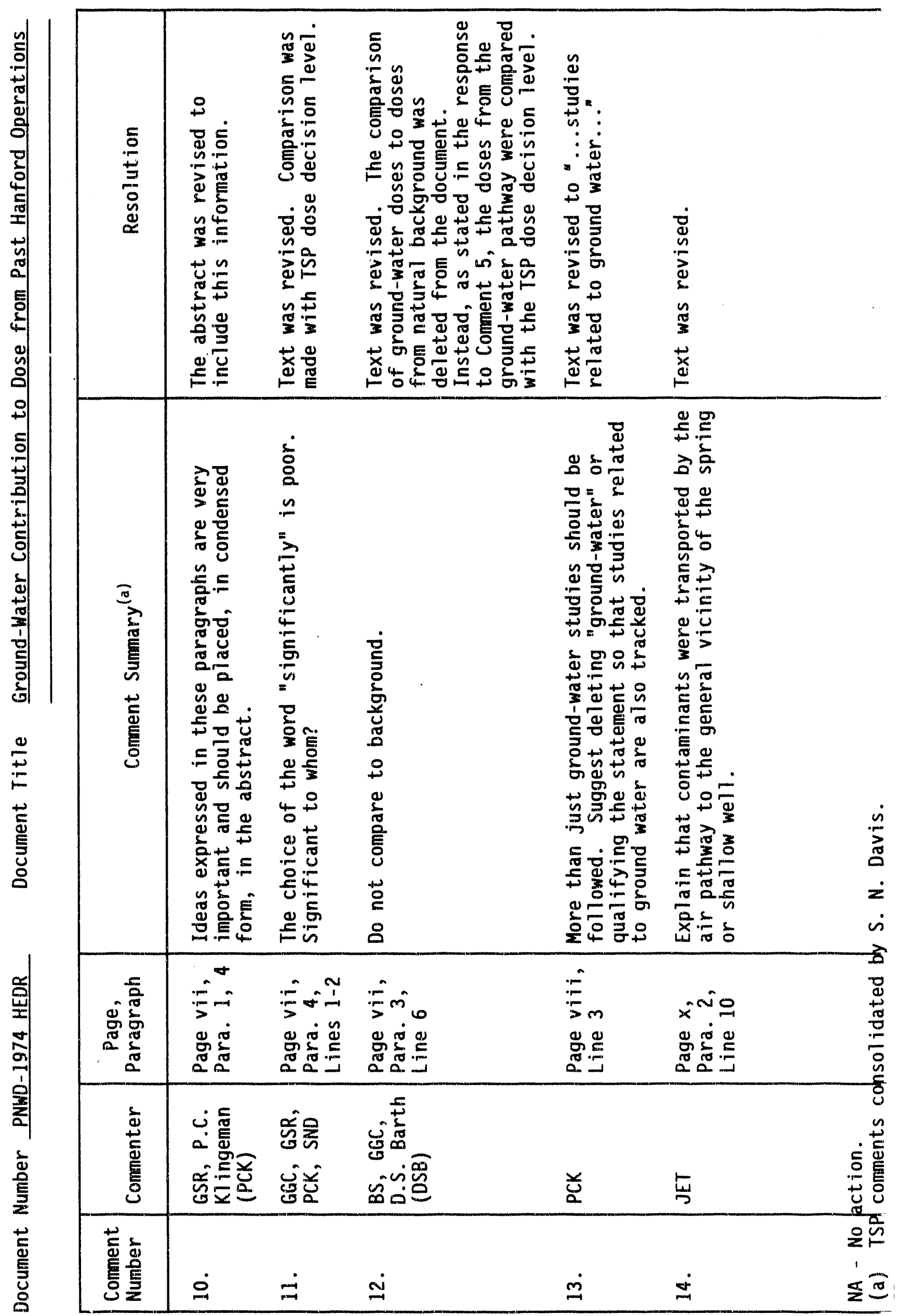




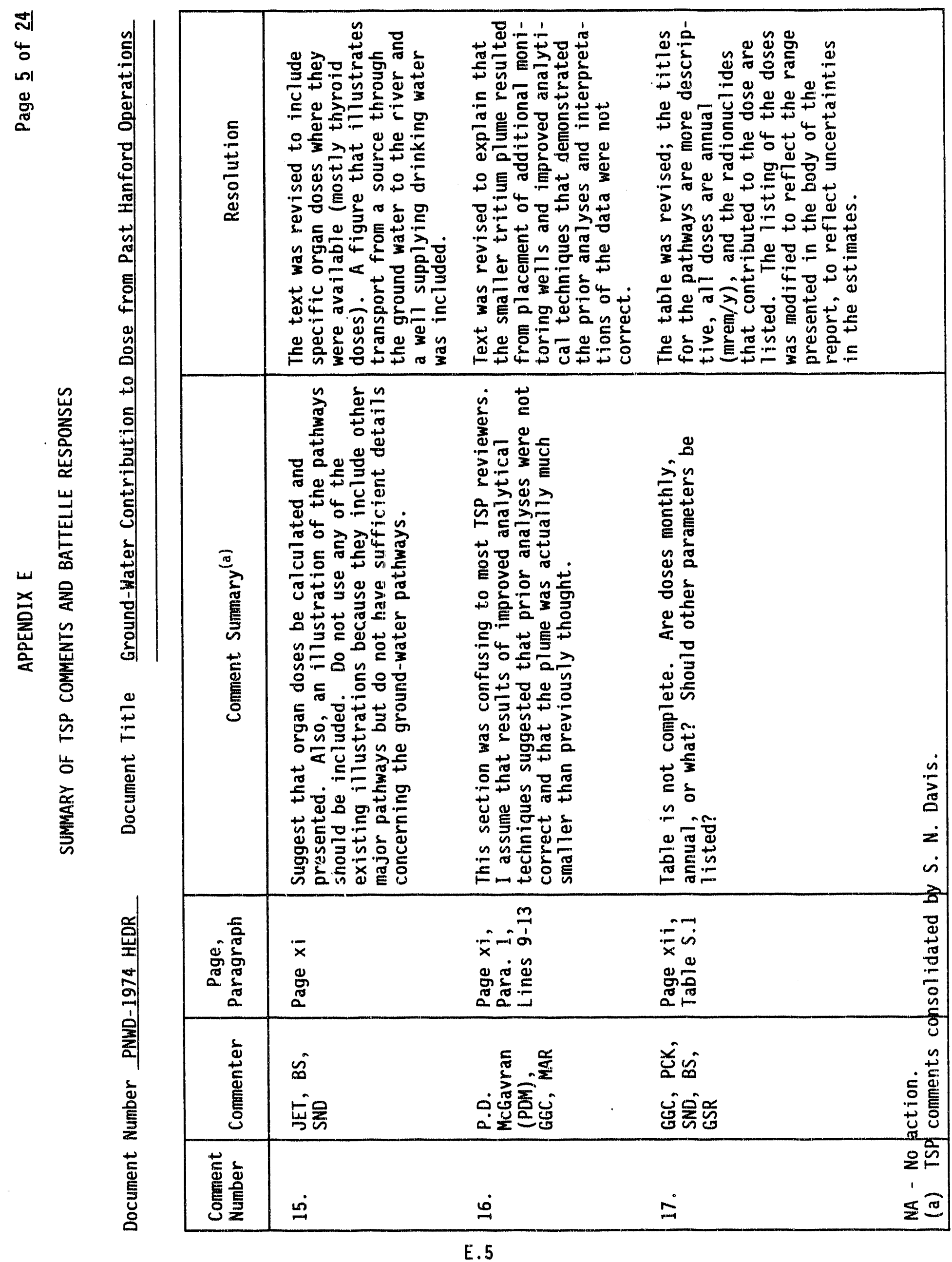




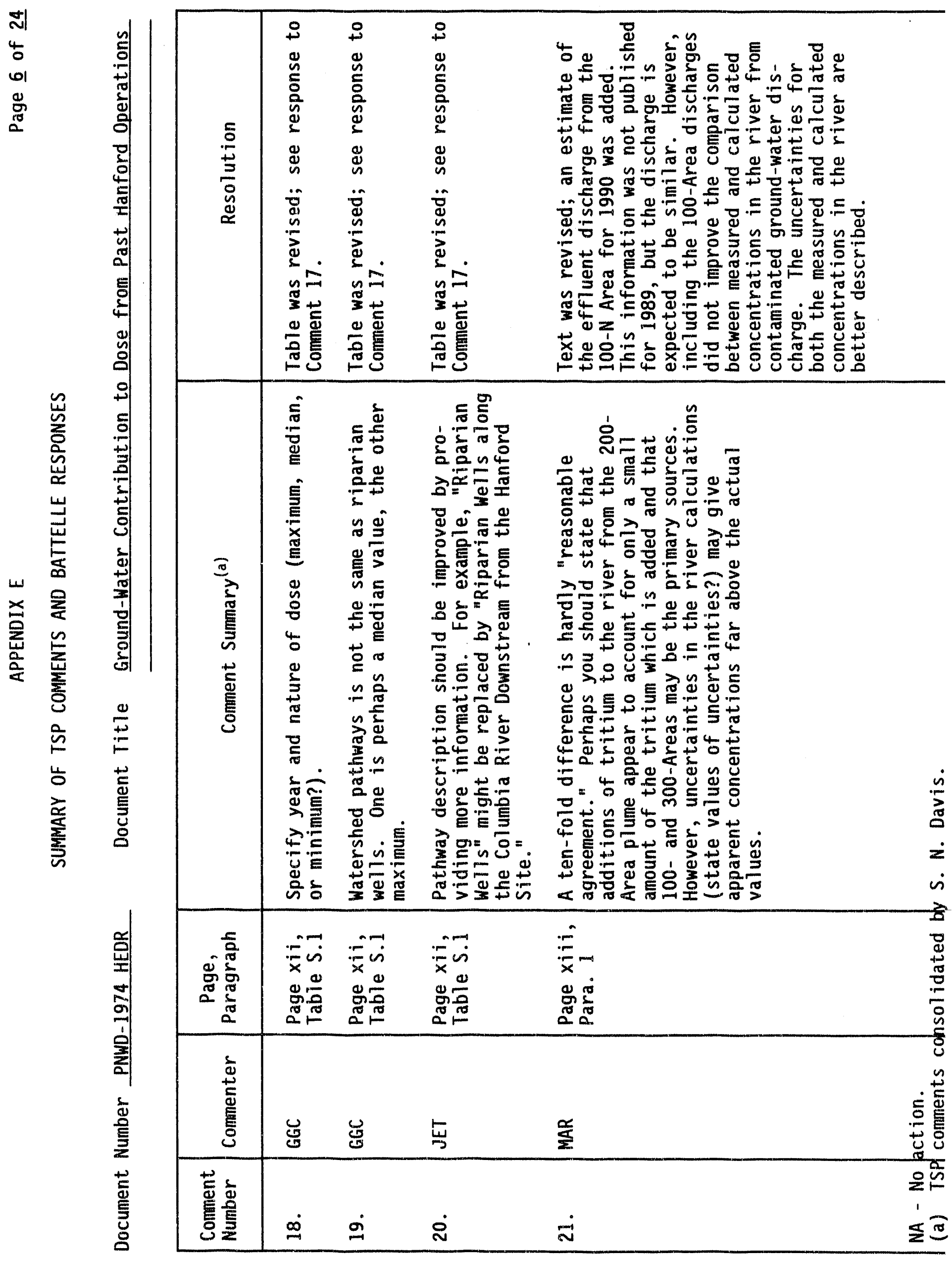


$\mathbb{N}$
4
0
$N$
$\mathbb{J}$
$\Xi$
$\Xi$

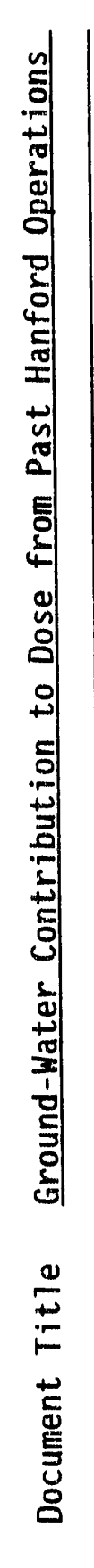

\begin{tabular}{|c|c|c|c|c|c|c|c|}
\hline 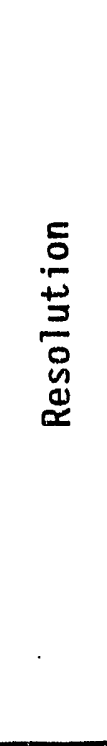 & 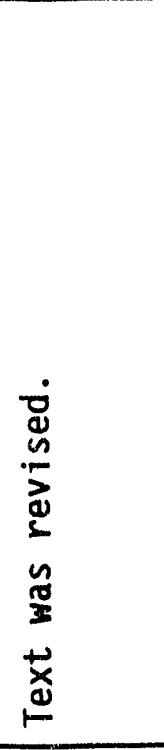 & 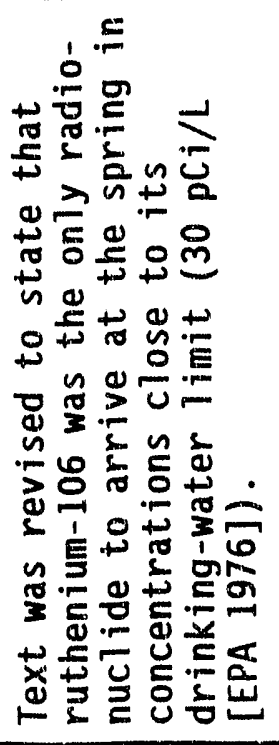 & 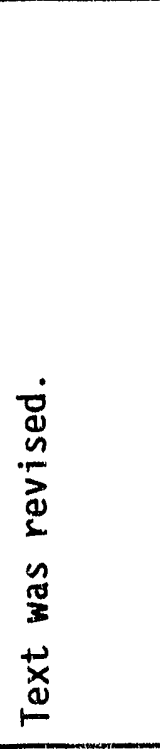 & 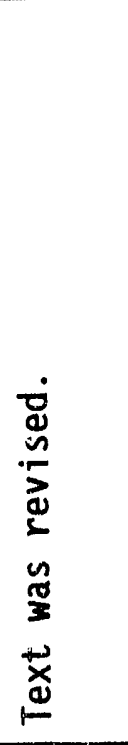 & 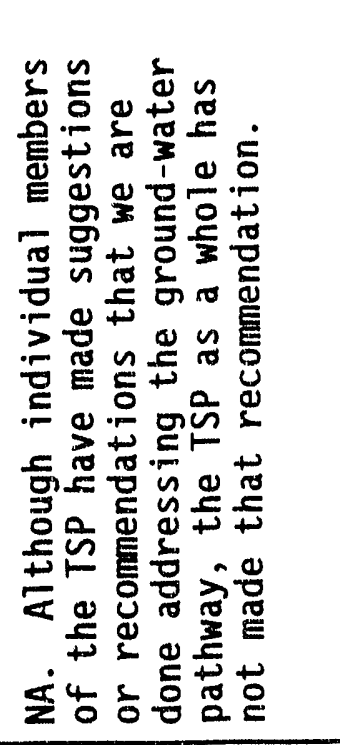 & 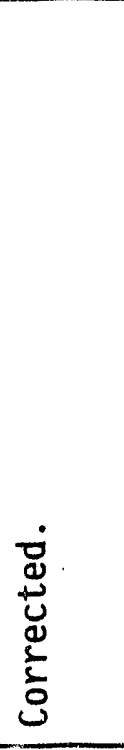 & \\
\hline 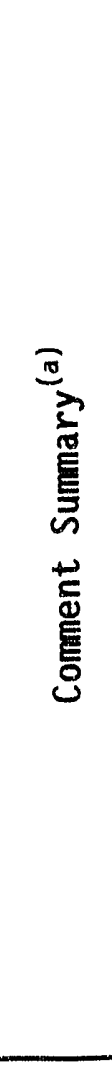 & 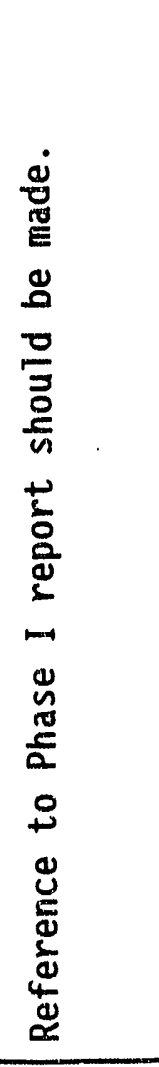 & 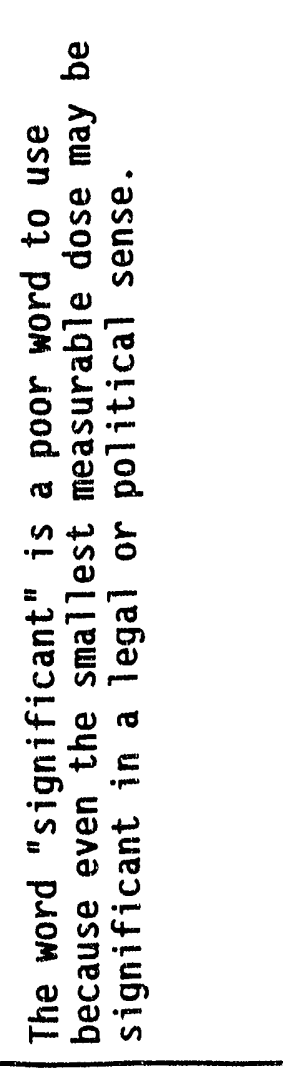 & 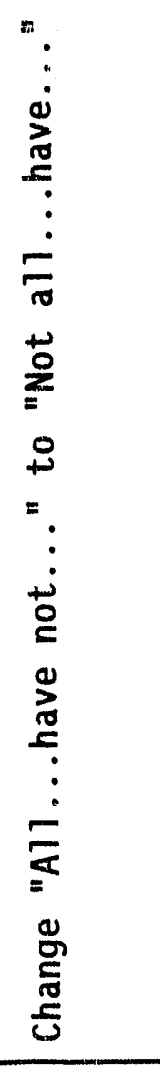 & 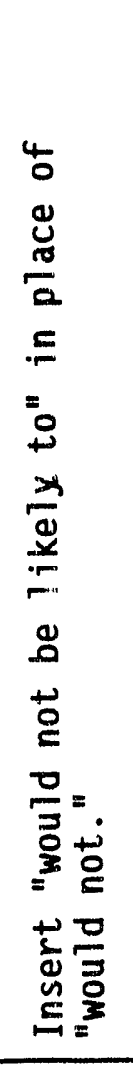 & 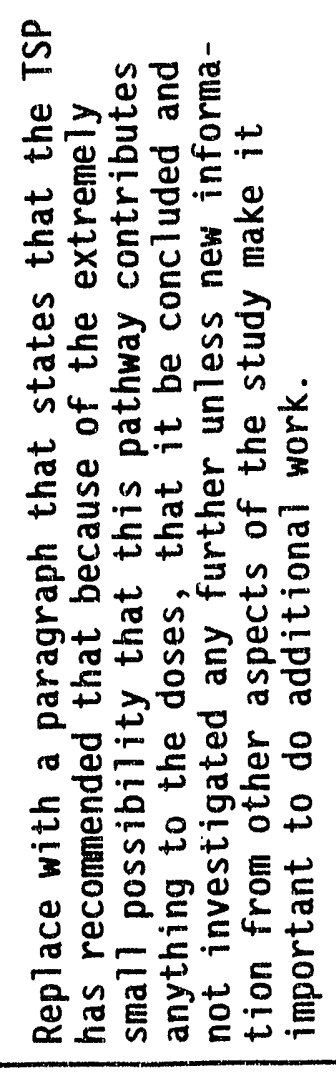 & 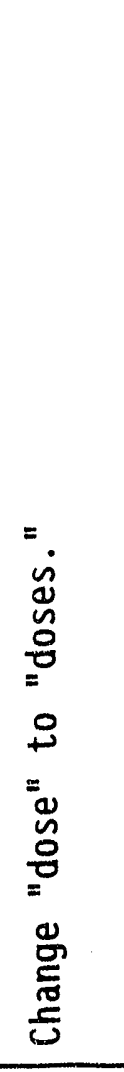 & $\begin{array}{l}\dot{n} \\
\dot{5} \\
\dot{0} \\
\dot{\sim} \\
\dot{\sim}\end{array}$ \\
\hline 竞竞 & 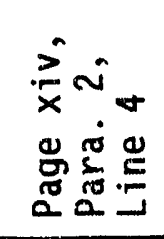 & 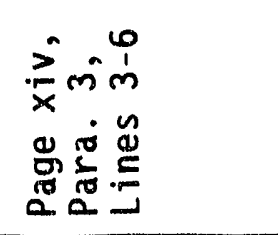 & 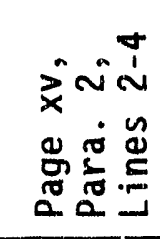 & 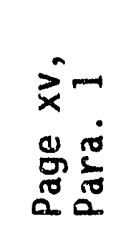 & 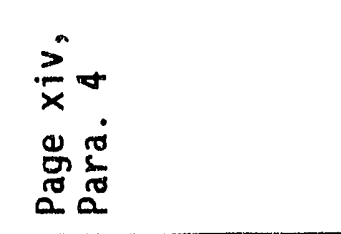 & 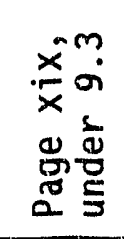 & 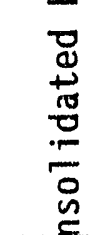 \\
\hline 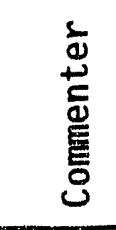 & 吕 & 吕 & 늠 & $\tilde{a}$ & 怘 & 芯 & 竞 \\
\hline 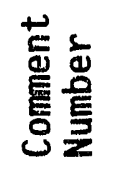 & $\tilde{N}$ & 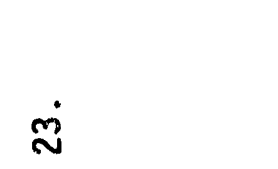 & d & $\stackrel{\llcorner}{\sim}$ & $\stackrel{\sim}{\sim}$ & $\approx$ & 정 \\
\hline
\end{tabular}




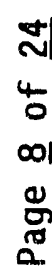
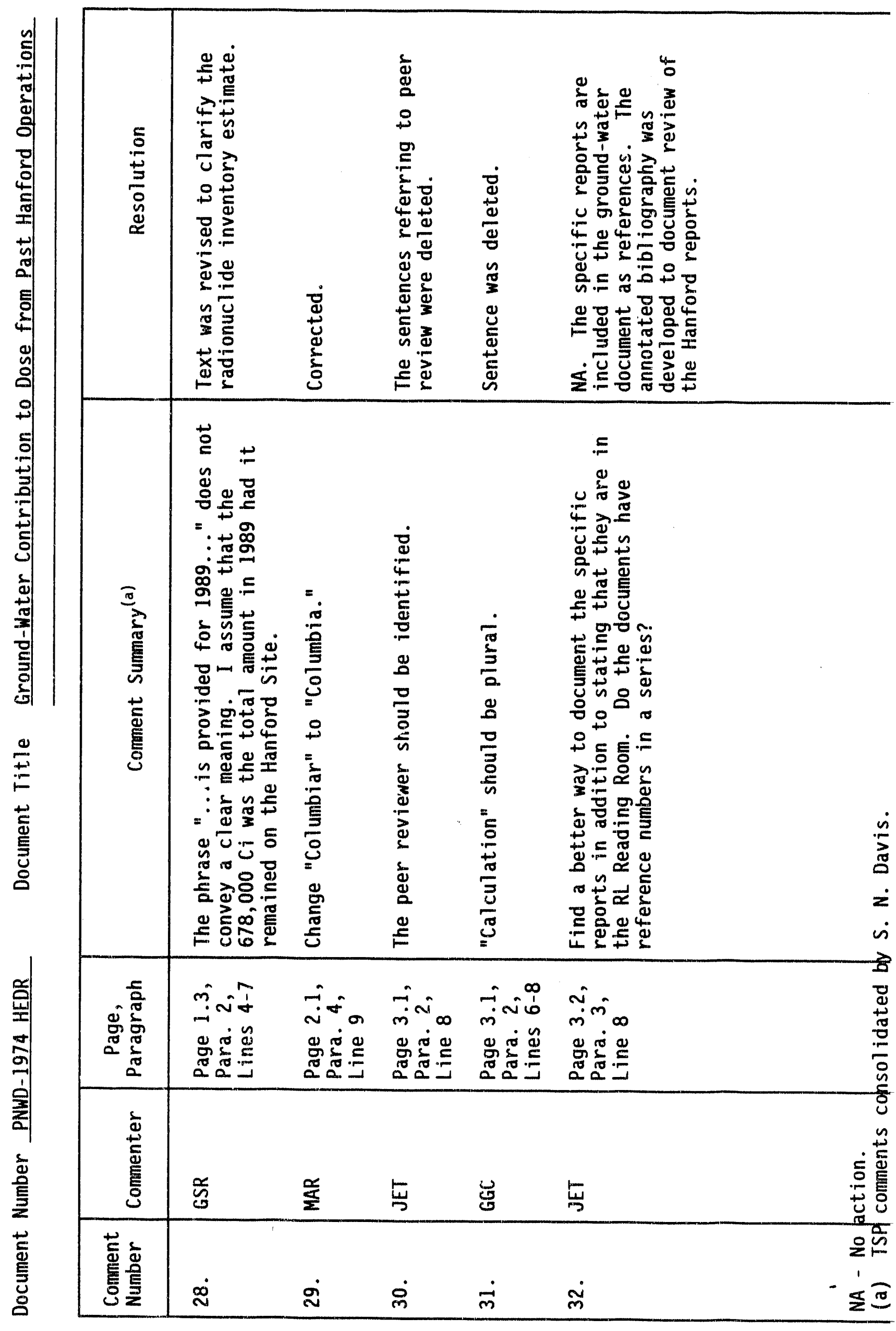

E. 8 


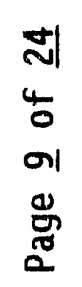

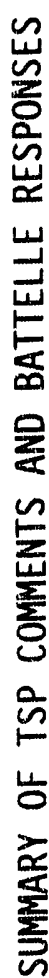

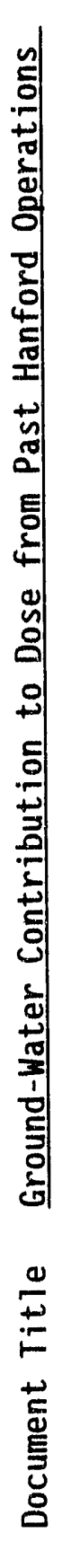

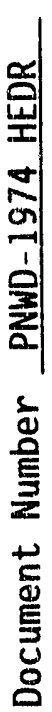

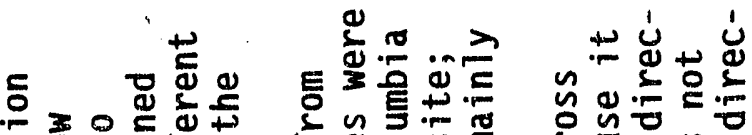

㞻出

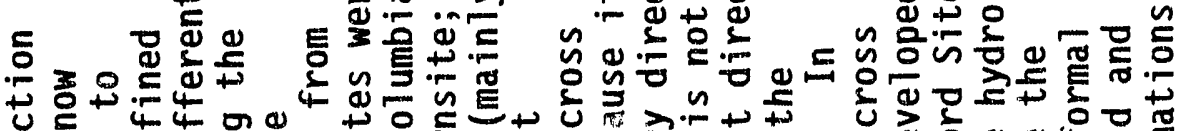

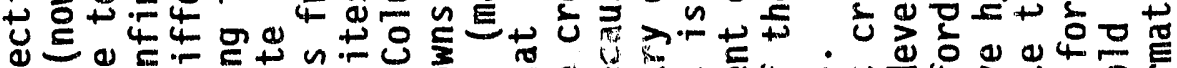

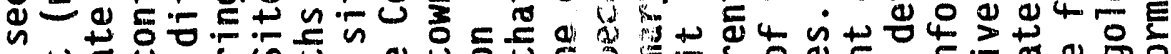

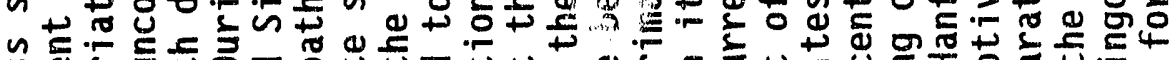

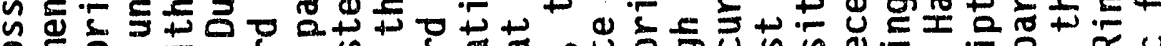

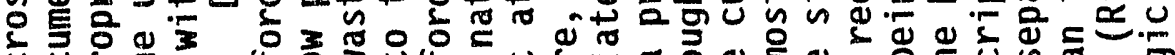
U U⿺辶寸

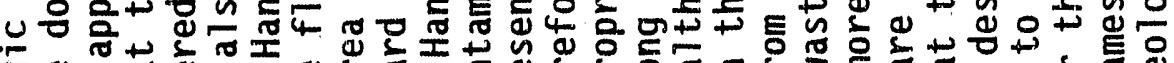

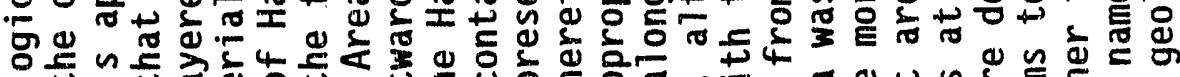

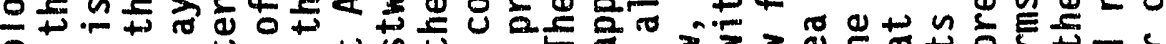

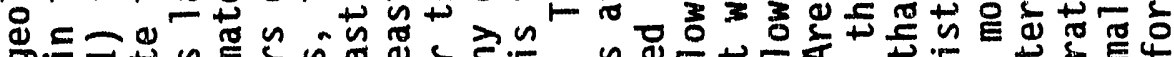

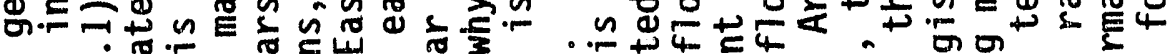
凹

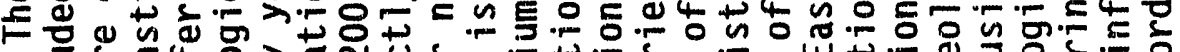

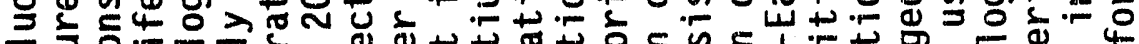

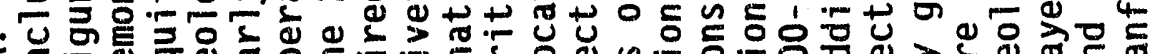

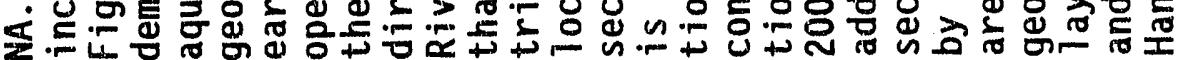

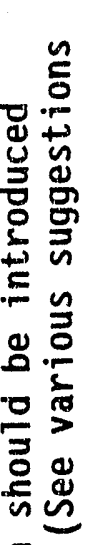

드.

ثิ

in

经垔

กับ

约

重至

它

g.

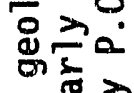

a

章 $\because$

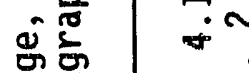

- $\frac{5}{10}$

雨

20

\begin{tabular}{|c|c|}
\hline 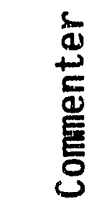 & 苟 \\
\hline 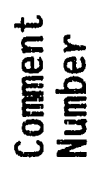 & $\dot{m}$ \\
\hline
\end{tabular}




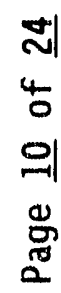

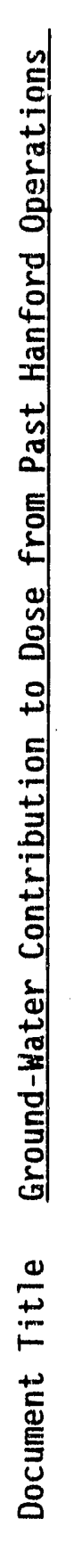

\begin{tabular}{|c|c|c|c|c|c|}
\hline 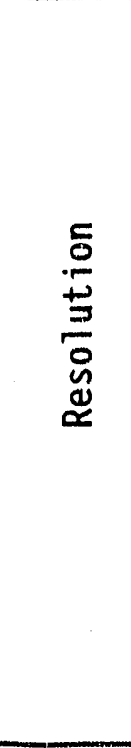 & 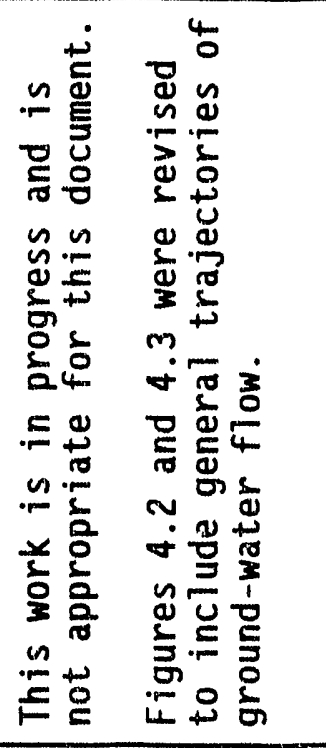 & 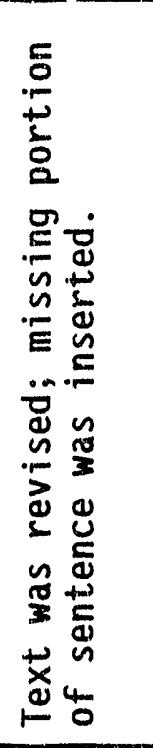 & 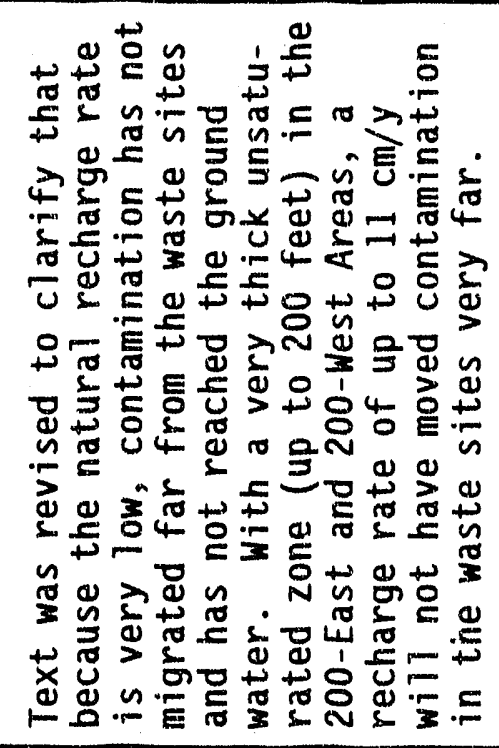 & 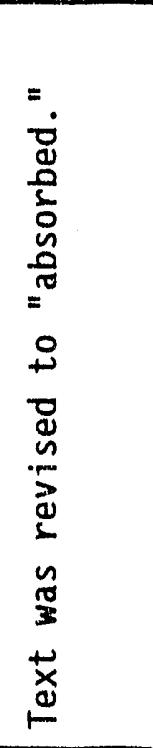 & \\
\hline 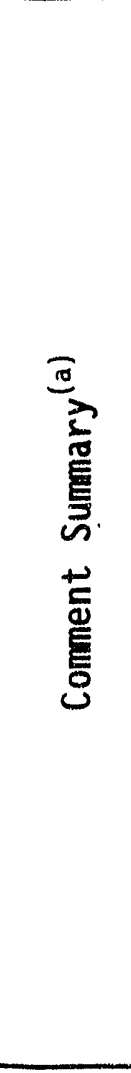 & 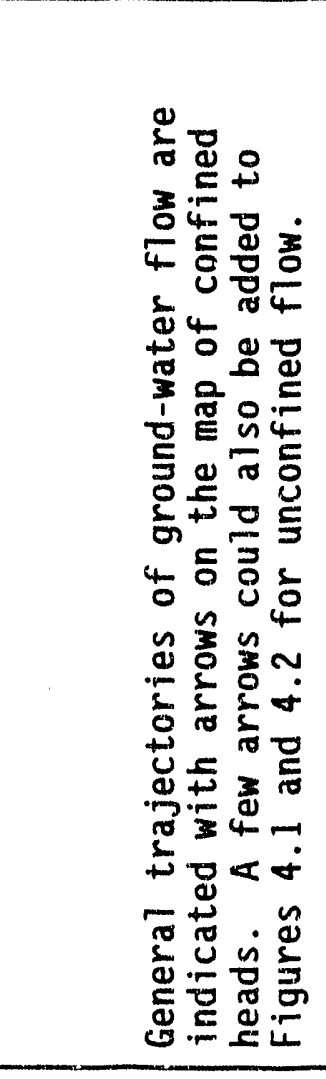 & 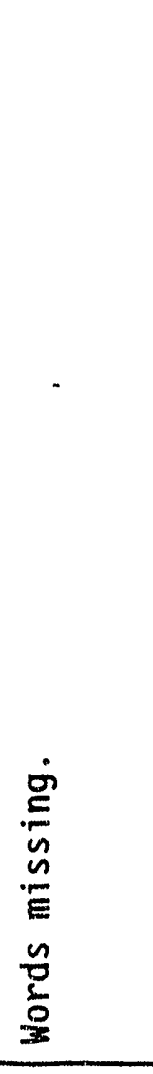 & 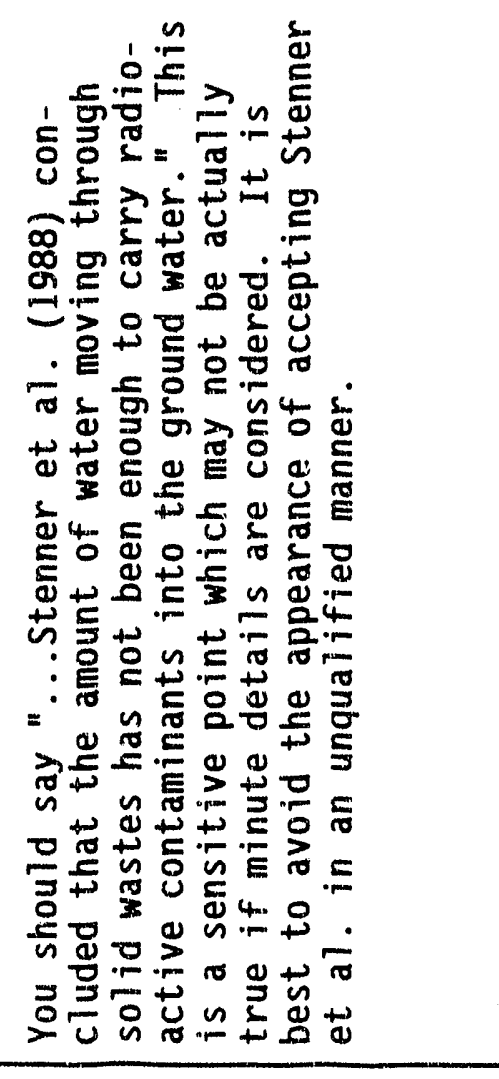 & 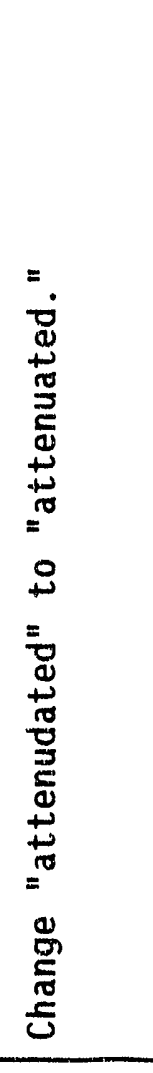 & $\begin{array}{l}\dot{n} \\
\dot{n} \\
\dot{z} \\
\dot{z} \\
\dot{n} \\
\dot{x}\end{array}$ \\
\hline 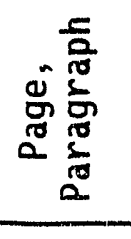 & 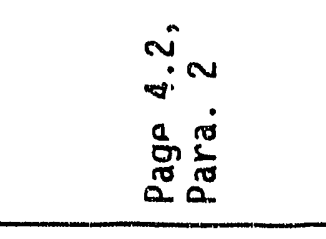 & 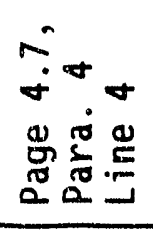 & 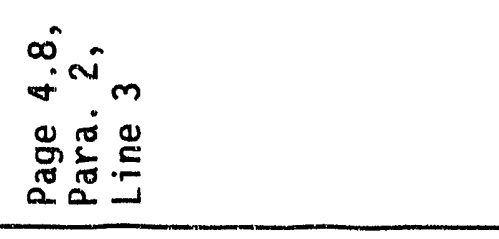 & 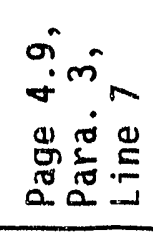 & 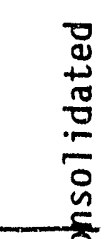 \\
\hline 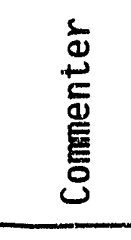 & $\frac{\frac{1}{2}}{2}$ & 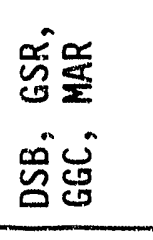 & & $\begin{array}{l}\frac{\alpha}{2} \\
\frac{0}{2} \\
\tilde{y} \\
\end{array}$ & 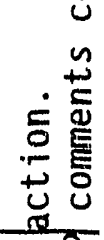 \\
\hline 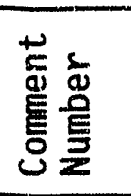 & ల్ల & 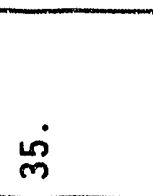 & $\dot{m}$ & $\hat{m}$ & 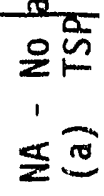 \\
\hline
\end{tabular}


메
4
0
0
0
0

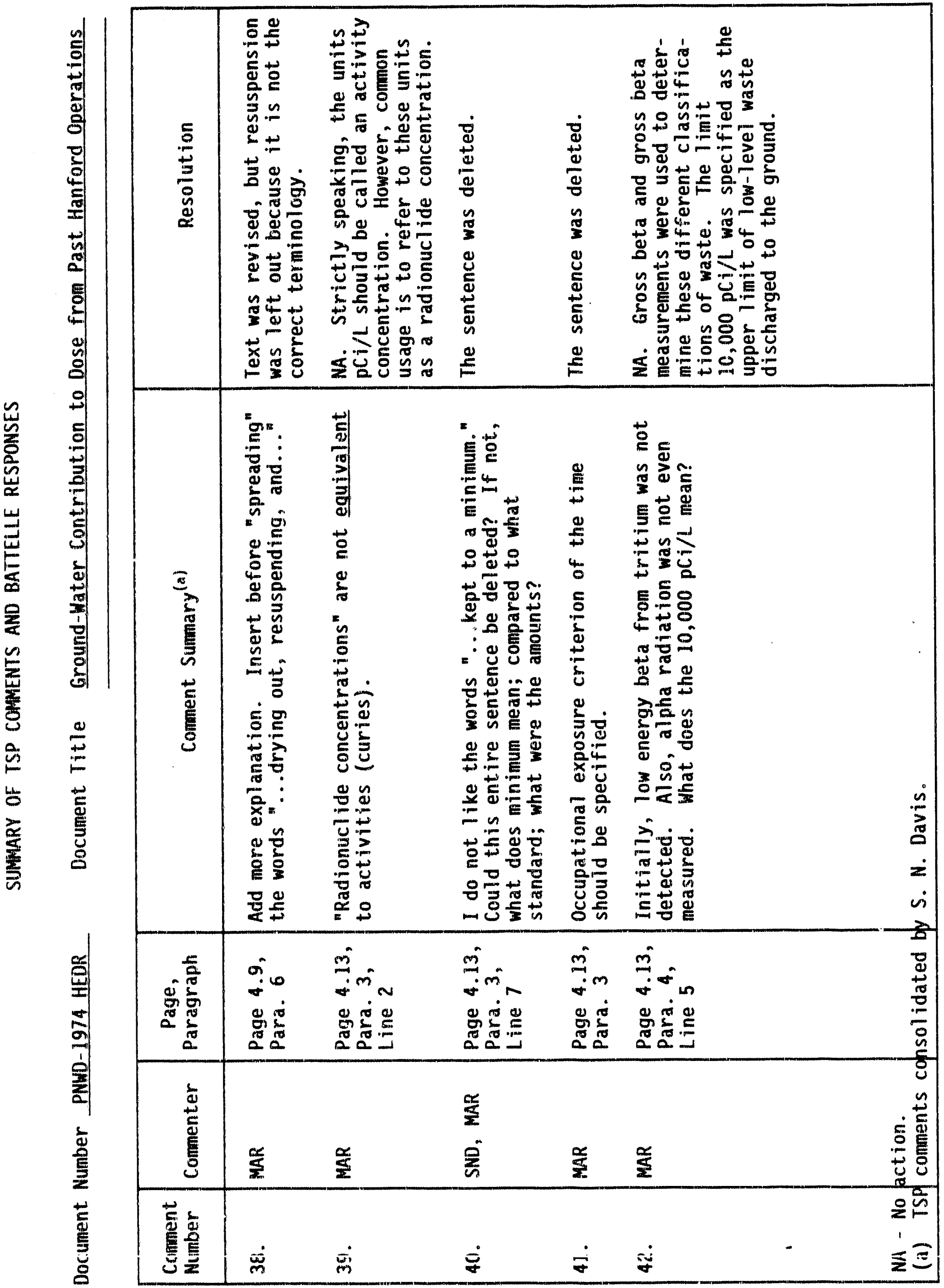


I
4
$\simeq$
$\cong$
0
0
0
0
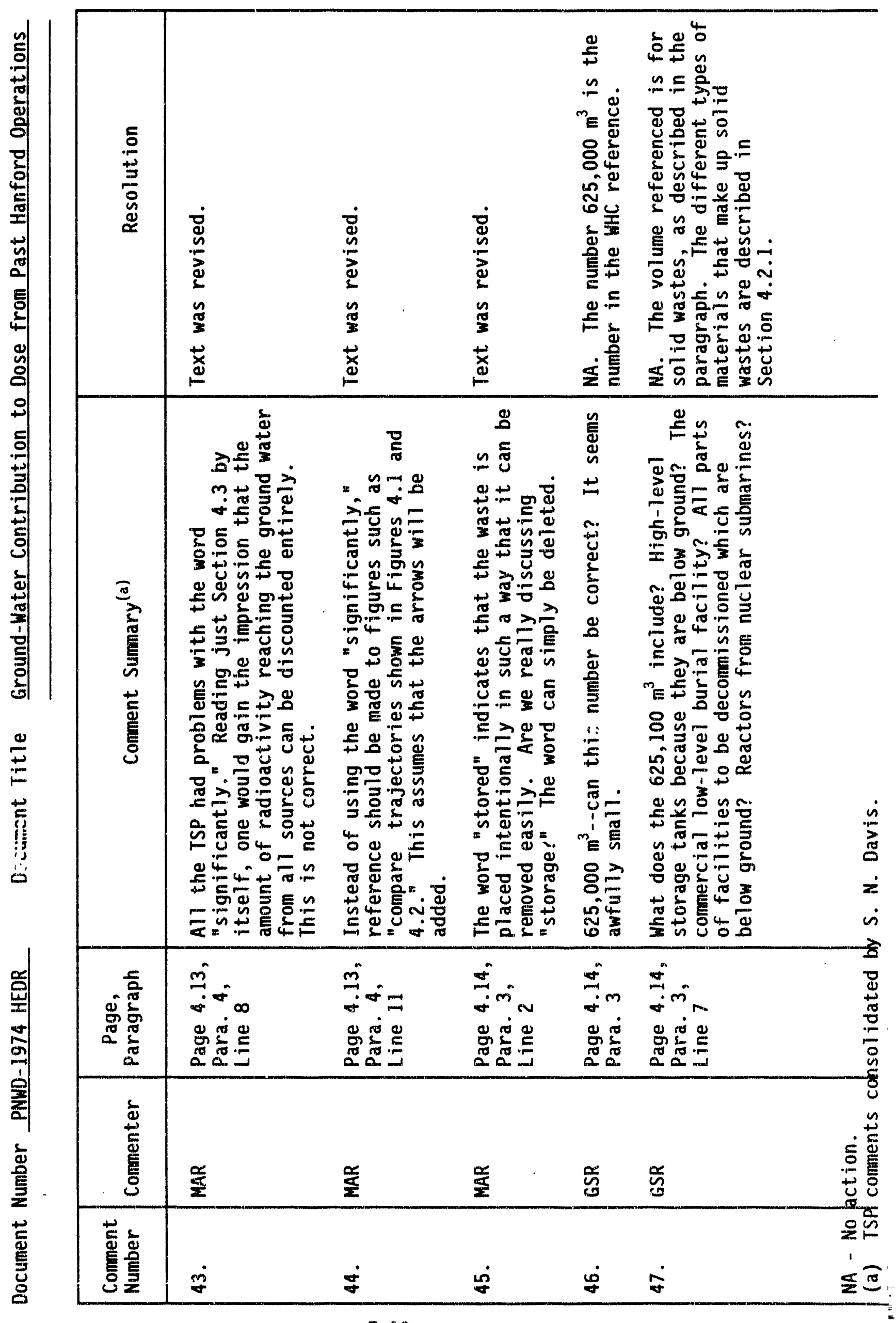


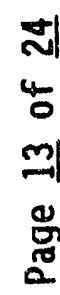

\begin{tabular}{|c|c|c|c|c|c|}
\hline 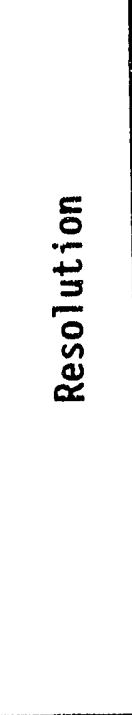 & 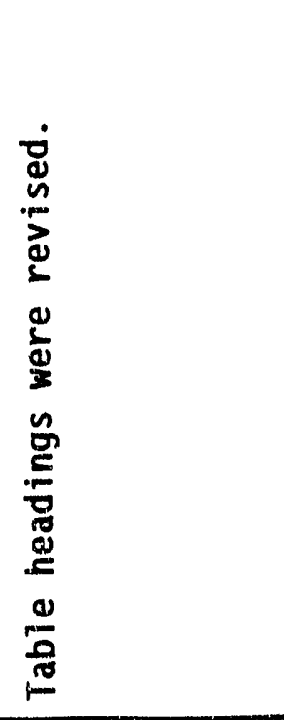 & 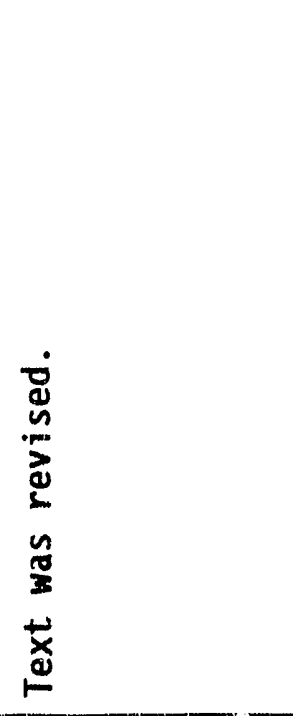 & 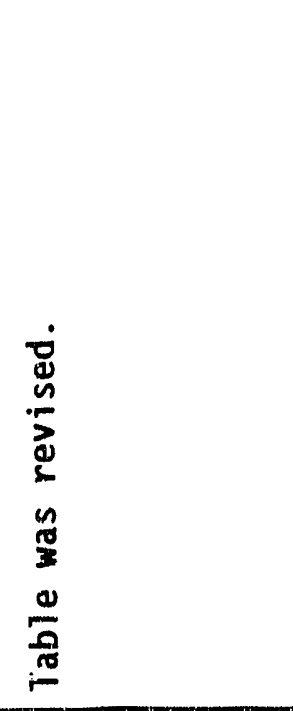 & 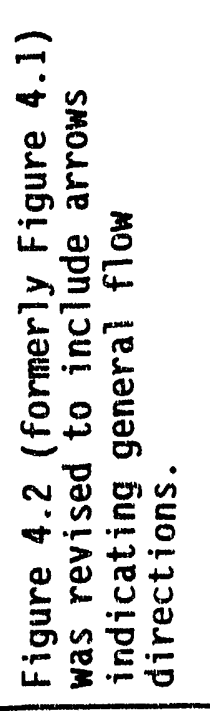 & \\
\hline 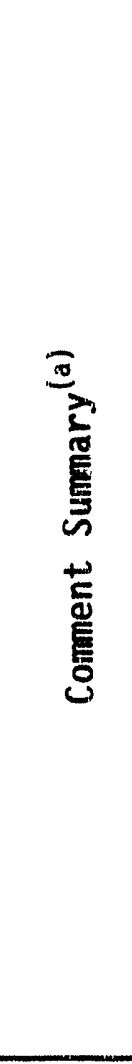 & 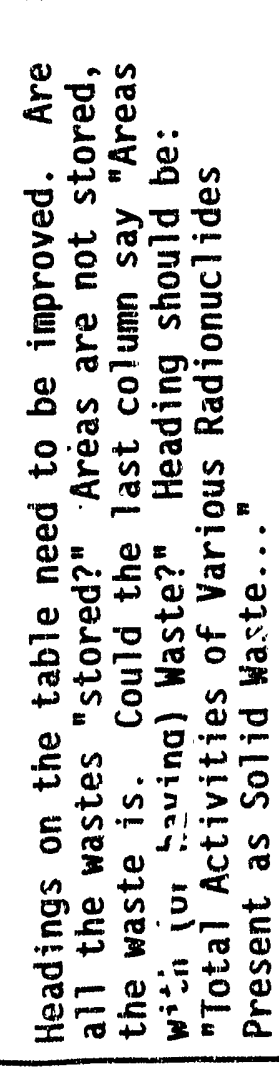 & 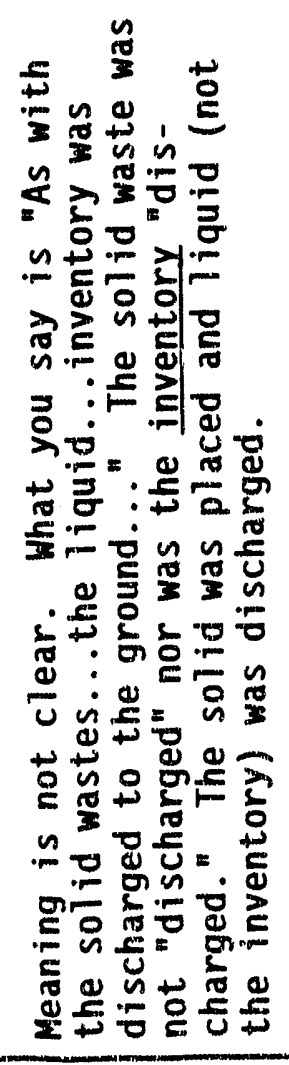 & 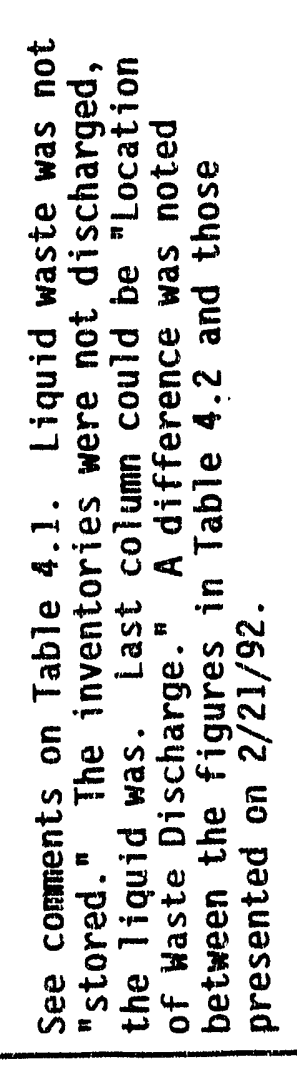 & 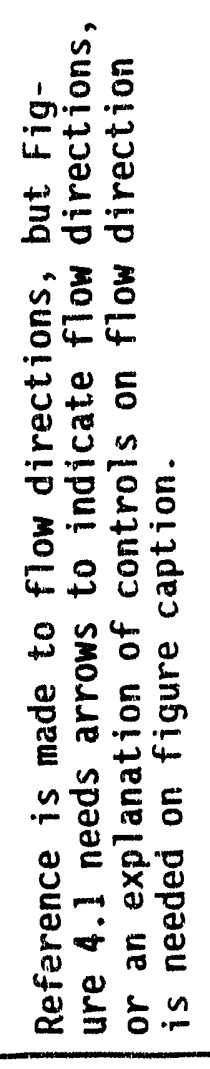 & $\begin{array}{l}\dot{x} \\
\dot{z} \\
0 \\
\dot{z} \\
\dot{v}\end{array}$ \\
\hline$\frac{5}{\sqrt[5]{\frac{2}{\pi}}}$ & 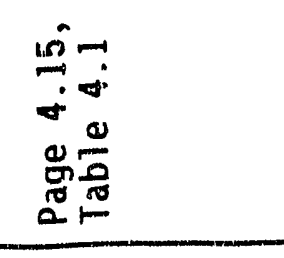 & 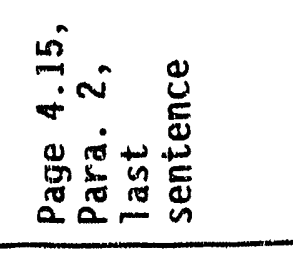 & 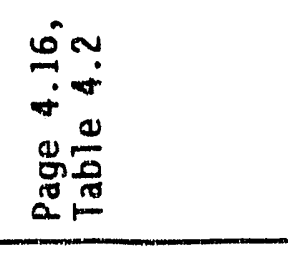 & 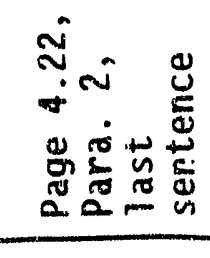 & 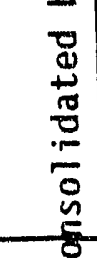 \\
\hline 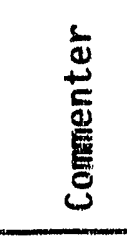 & 兑 & 吕 & $\begin{array}{l}\frac{\alpha}{2} \\
\frac{\alpha}{2} \\
\frac{\alpha}{2}\end{array}$ & 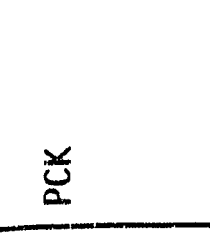 & 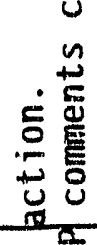 \\
\hline 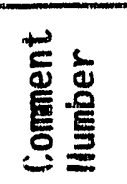 & $\stackrel{\mathscr{O}}{=}$ & $\stackrel{8}{9}$ & : & in & $\begin{array}{l}205 \\
200 \\
20\end{array}$ \\
\hline
\end{tabular}


\pm
4
4
$\vdots$
\pm
0
0
0
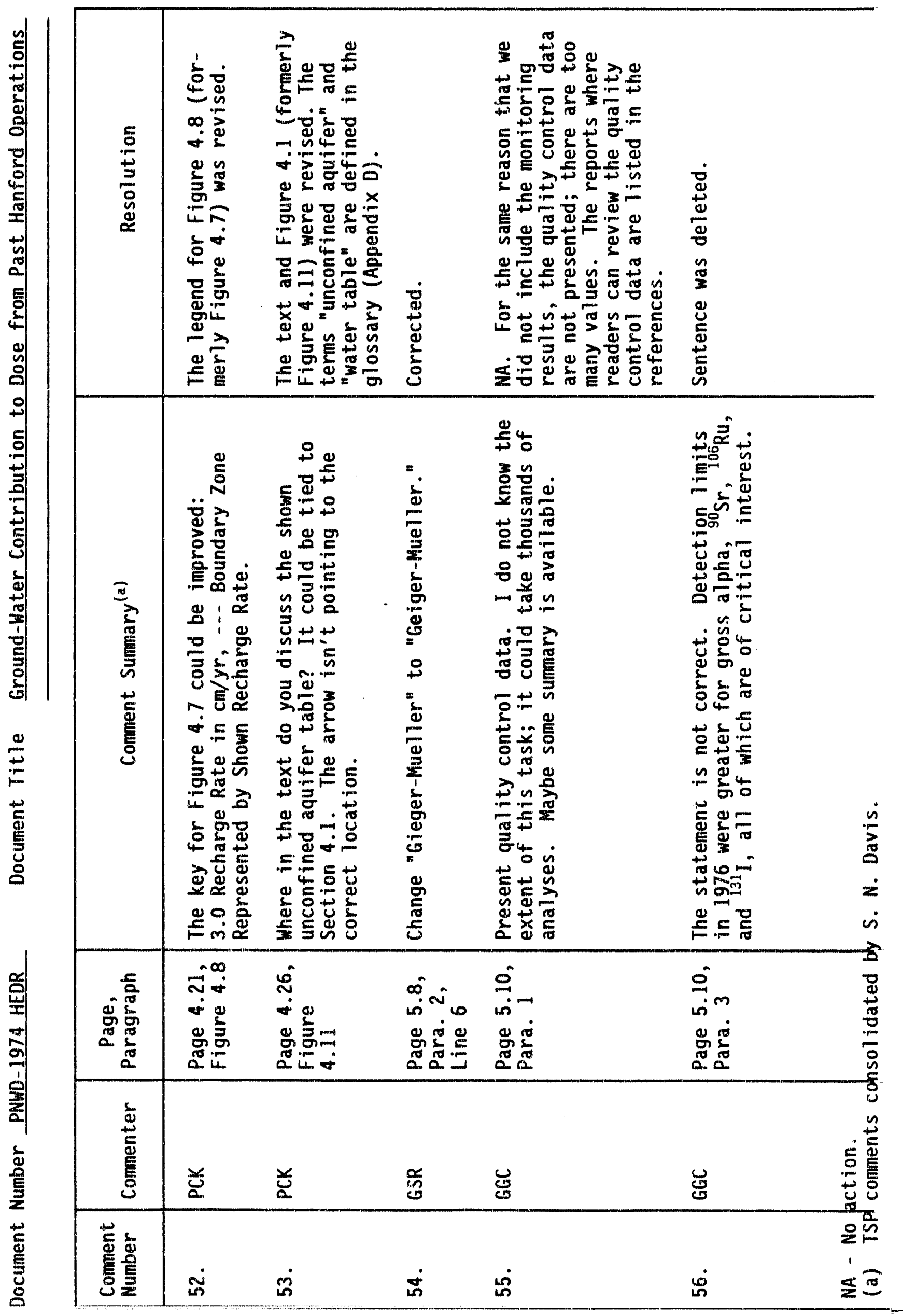

E. 14 


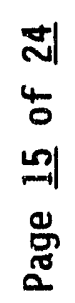

\begin{tabular}{|c|c|c|c|c|}
\hline 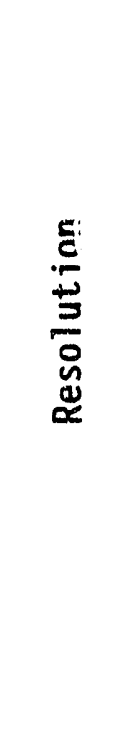 & 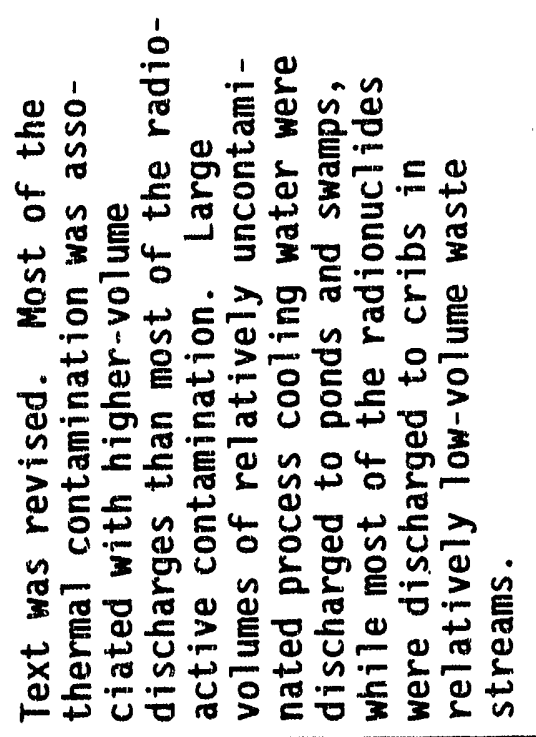 & 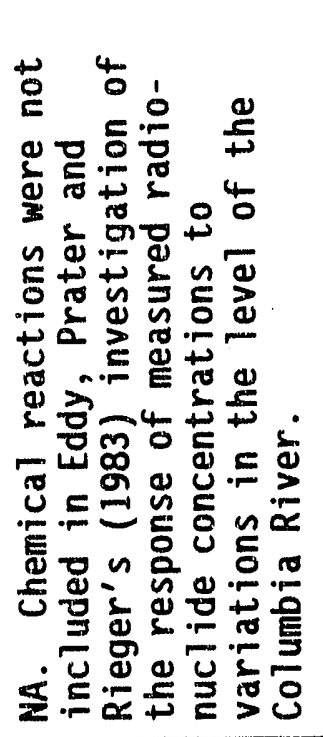 & 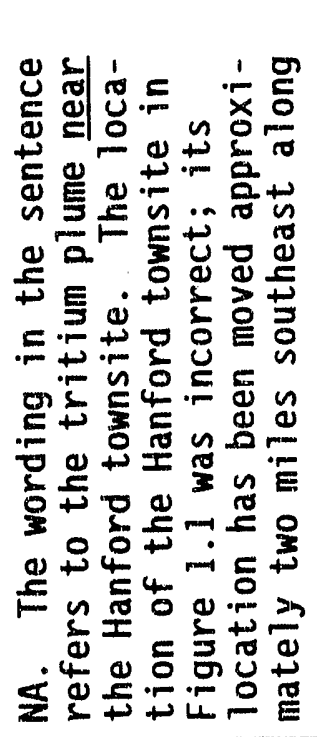 & . \\
\hline 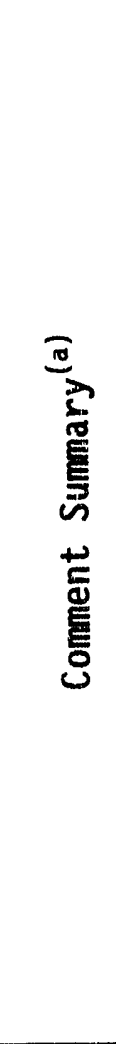 & 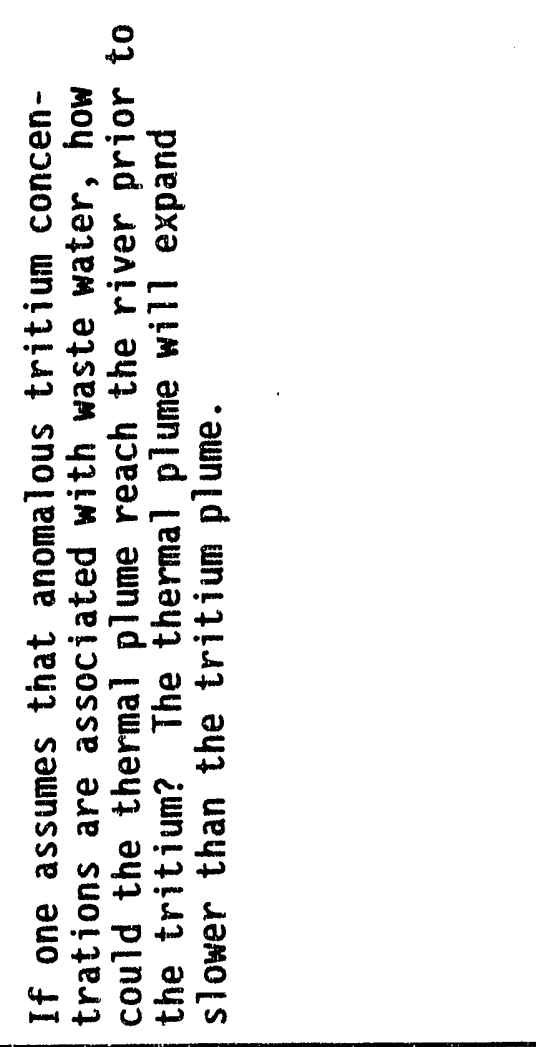 & 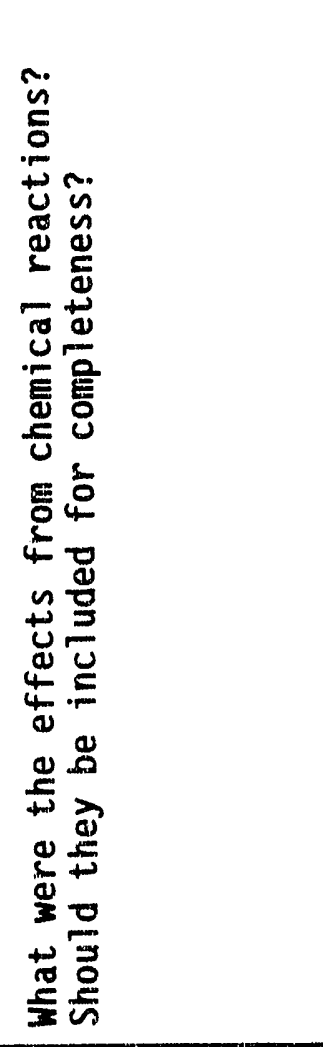 & 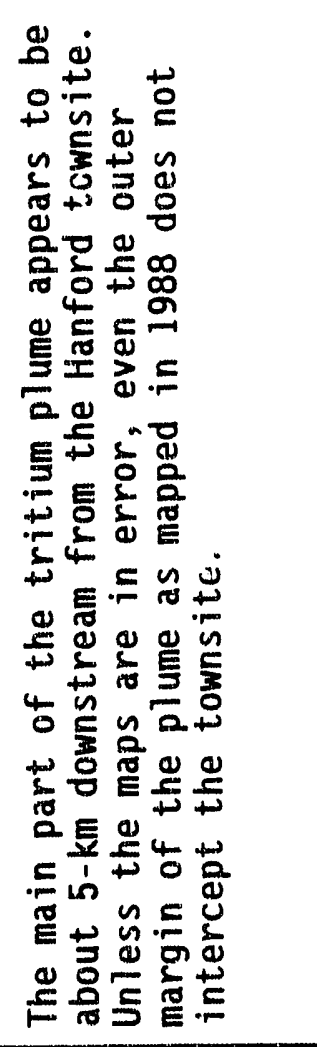 & 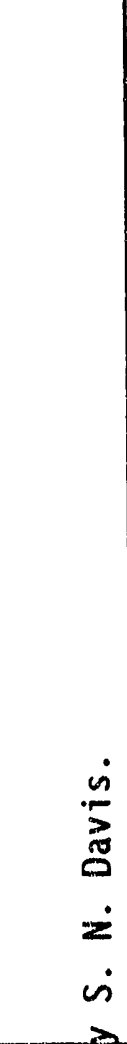 \\
\hline 总 & 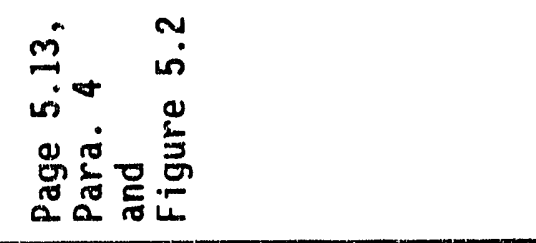 & 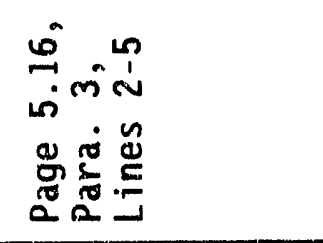 & 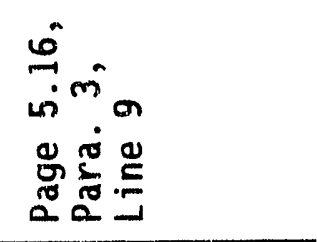 & 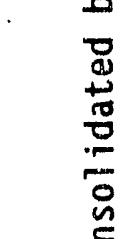 \\
\hline 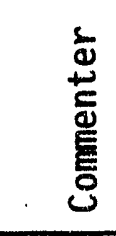 & $\overleftrightarrow{0}$ & $\underset{⿱ n}{0}$ & 比 & 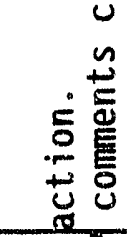 \\
\hline 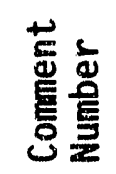 & in & 需 & 品 & $\begin{array}{l}0=1 \\
\Sigma 00\end{array}$ \\
\hline
\end{tabular}




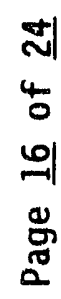

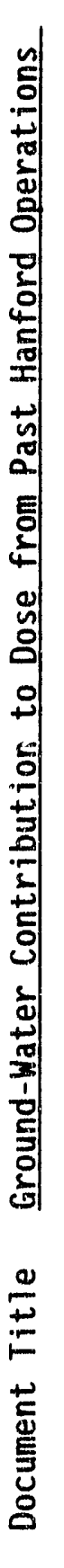

\begin{tabular}{|c|c|c|c|c|c|c|}
\hline 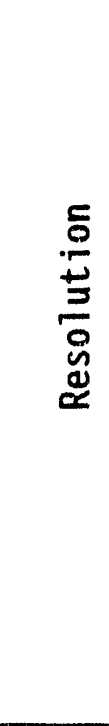 & 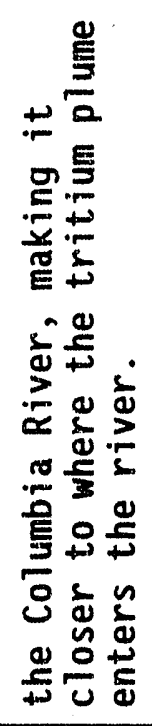 & 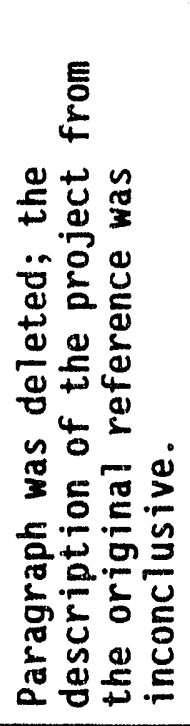 & 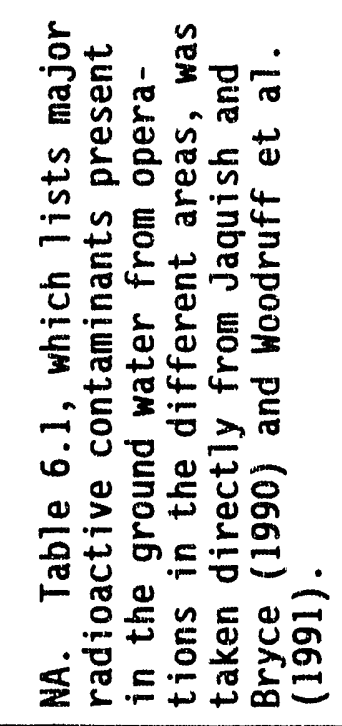 & 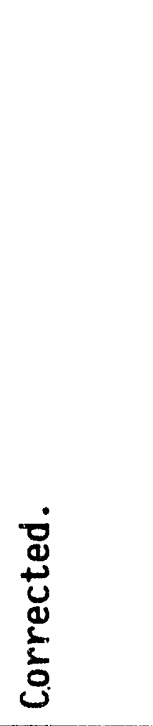 & 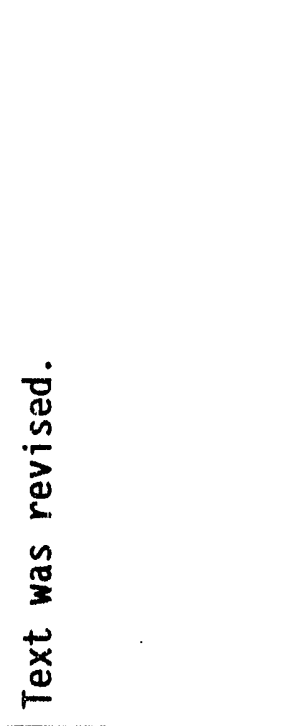 & \\
\hline 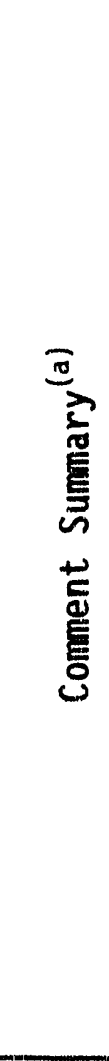 & & 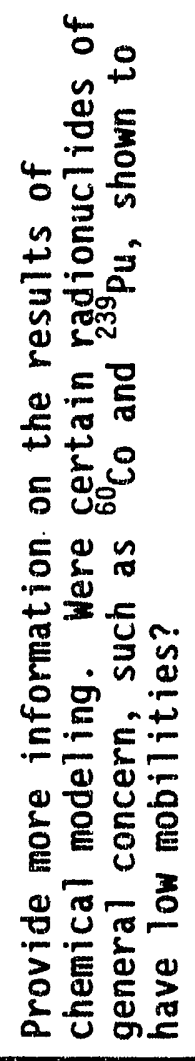 & 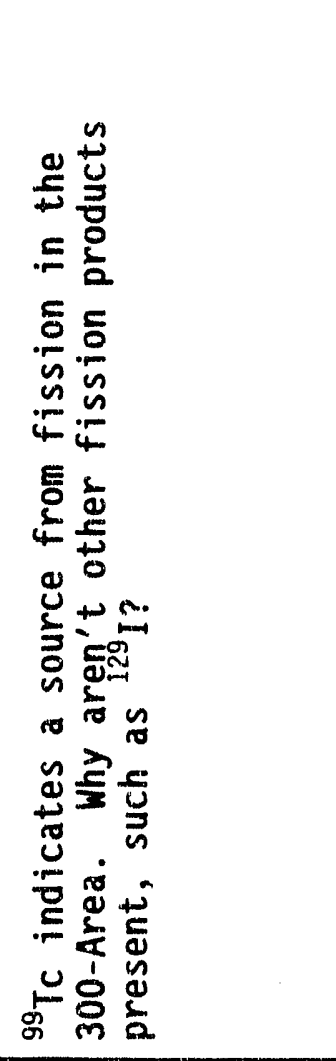 & 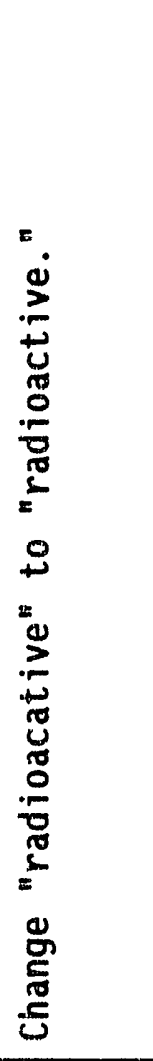 & 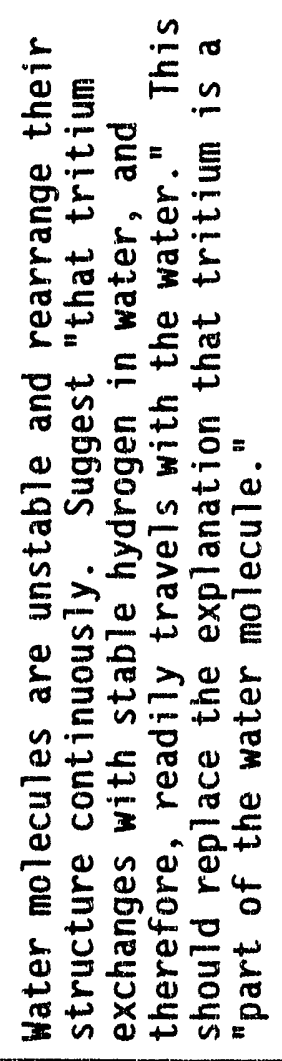 & $\begin{array}{l}\dot{n} \\
\dot{z} \\
\dot{a} \\
\dot{z} \\
\dot{n}\end{array}$ \\
\hline 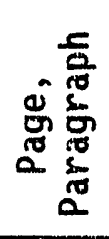 & & 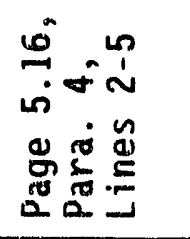 & 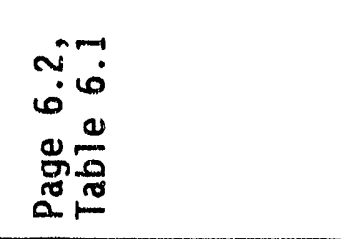 & 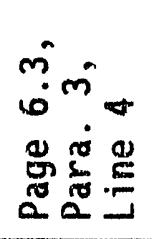 & 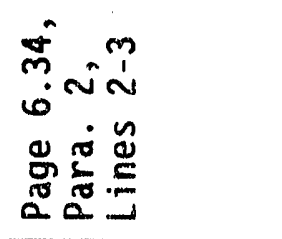 & 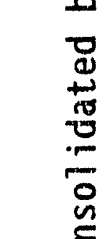 \\
\hline 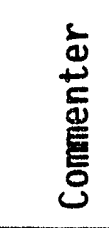 & & 总 & 笭 & $\frac{\frac{x}{2}}{2}$ & $\frac{\frac{x}{x}}{2}$ & 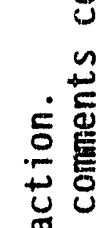 \\
\hline 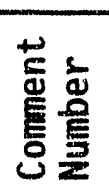 & & 8 & $\dot{0}$ & ஸ் & 8 & 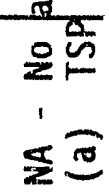 \\
\hline
\end{tabular}




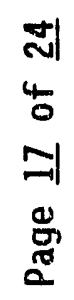

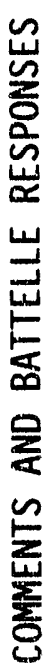

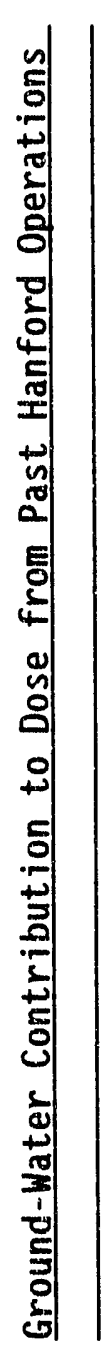

\begin{tabular}{|c|c|c|c|c|}
\hline 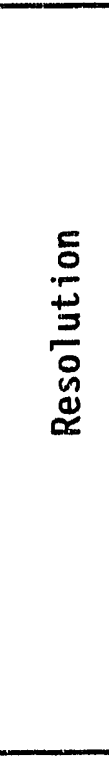 & 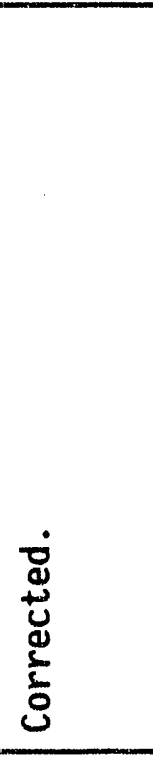 & 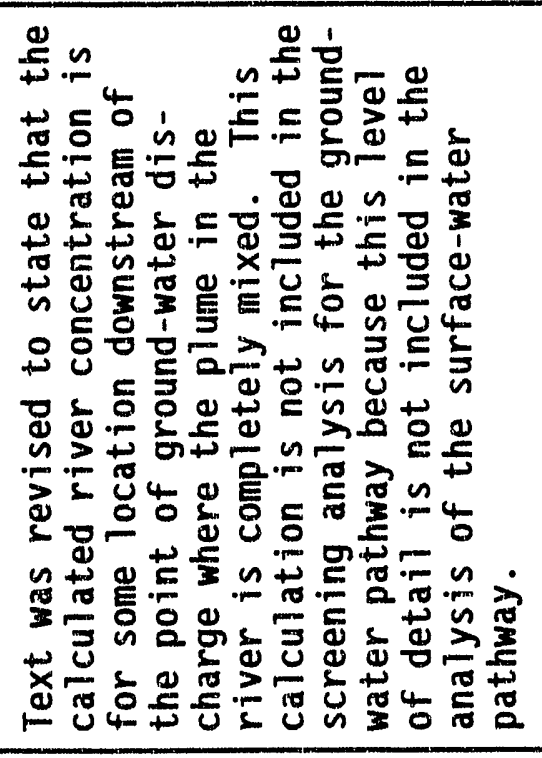 & 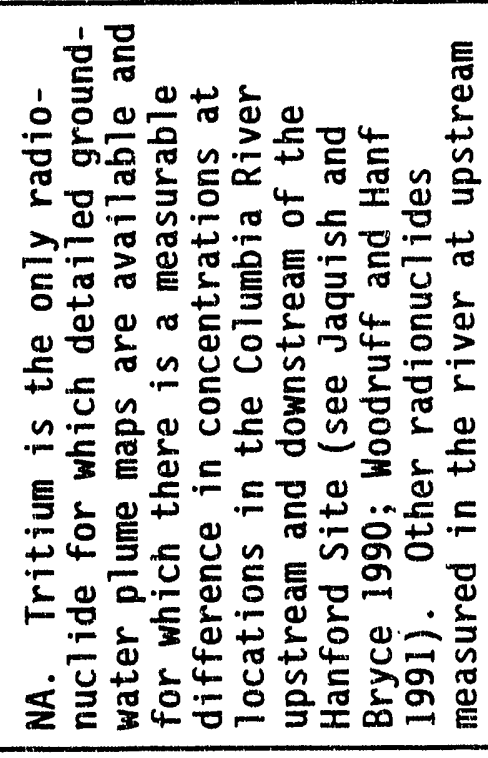 & \\
\hline 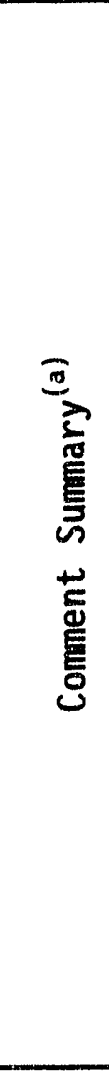 & 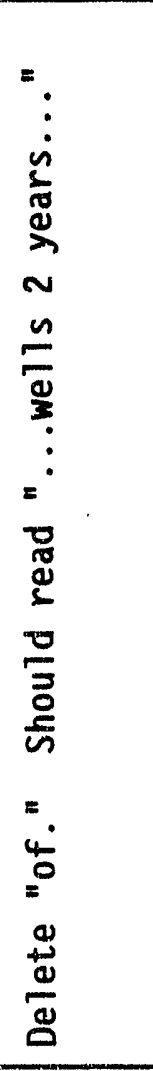 & 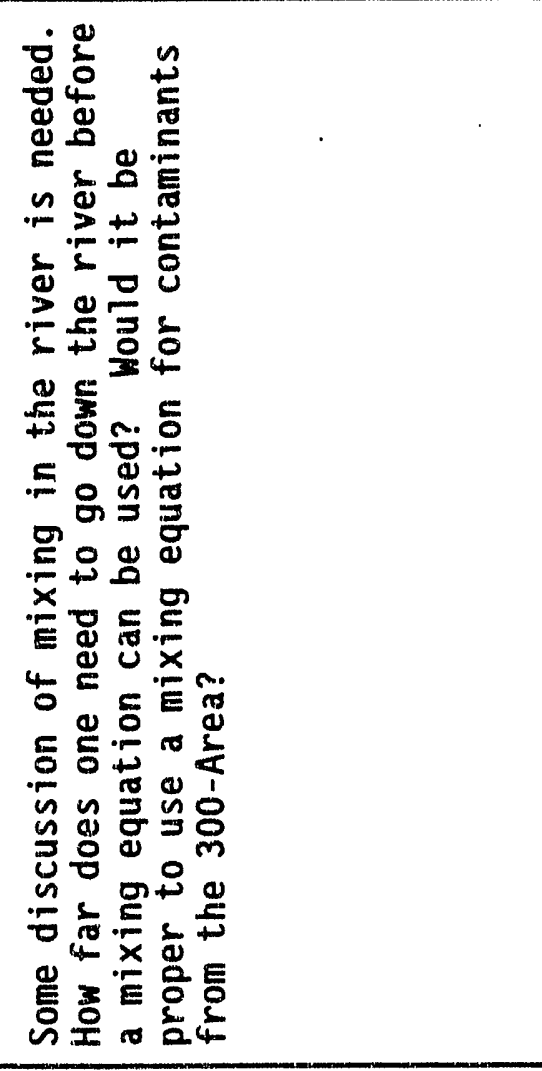 & 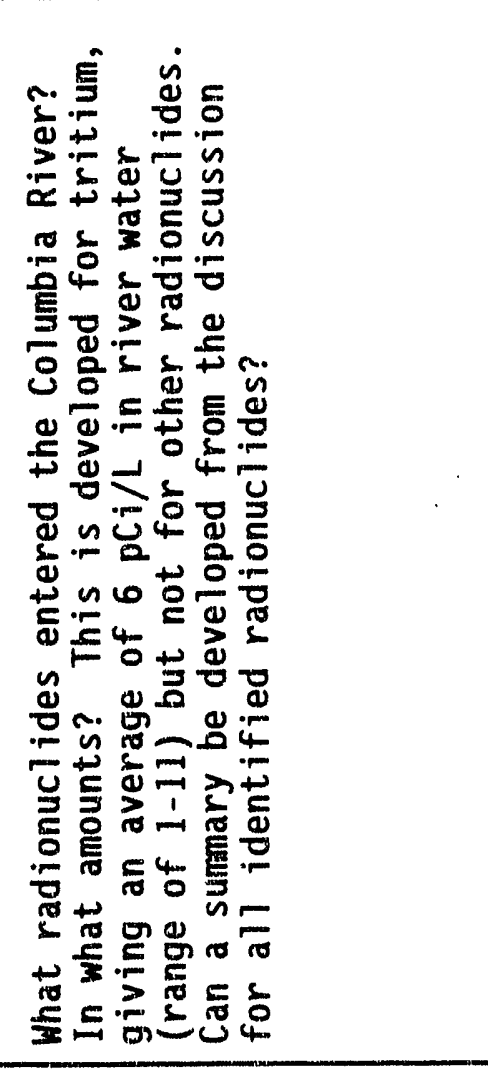 & $\begin{array}{l}\dot{n} \\
\dot{z} \\
0 \\
\dot{z} \\
\dot{v} \\
\dot{z}\end{array}$ \\
\hline 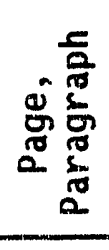 & 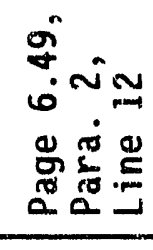 & 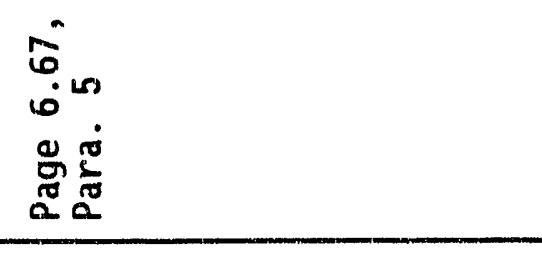 & 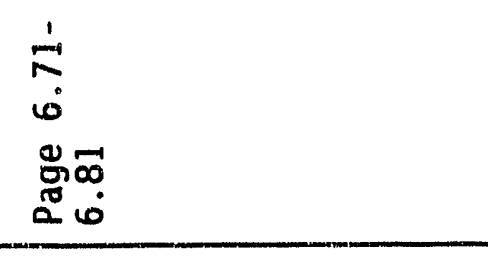 & 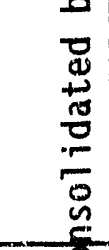 \\
\hline 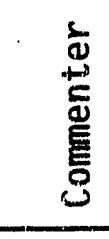 & $\frac{\alpha}{2}$ & $\frac{\frac{\alpha}{2}}{2}$ & 弟 & 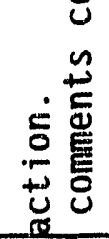 \\
\hline 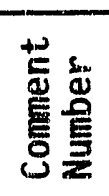 & I & 8 & 8 & 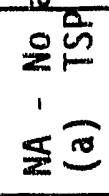 \\
\hline
\end{tabular}




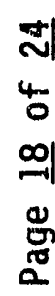
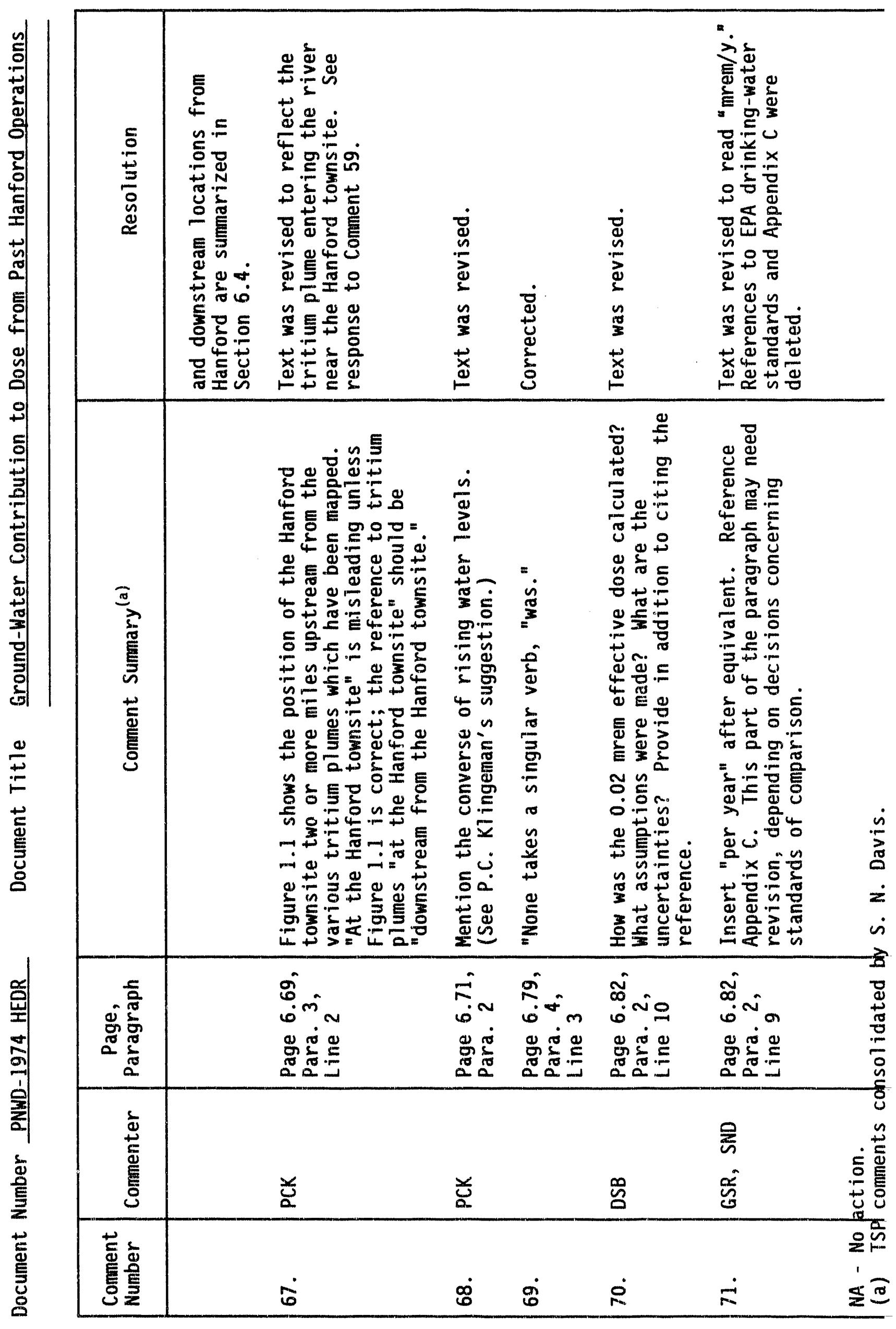


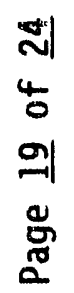

\begin{tabular}{|c|c|c|c|c|c|c|c|}
\hline 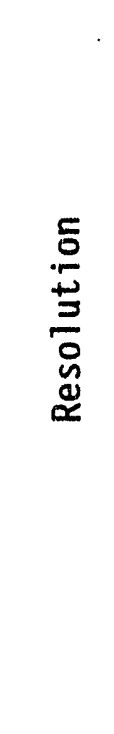 & 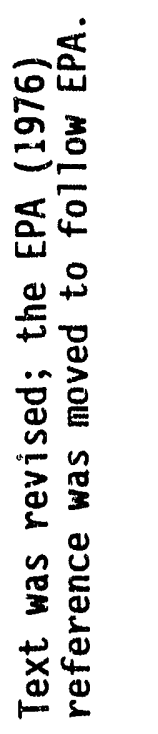 & 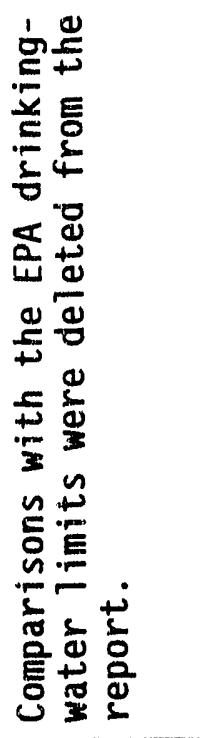 & 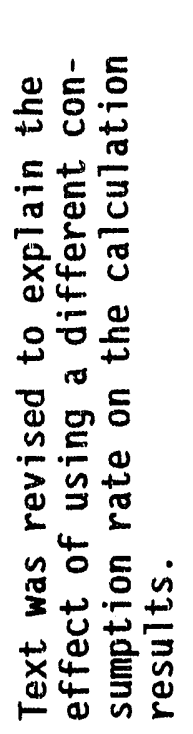 & 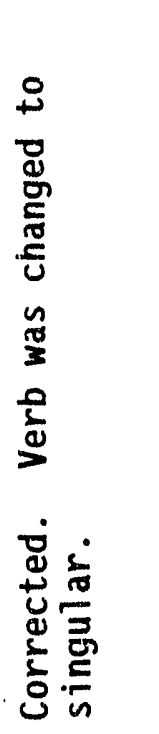 & 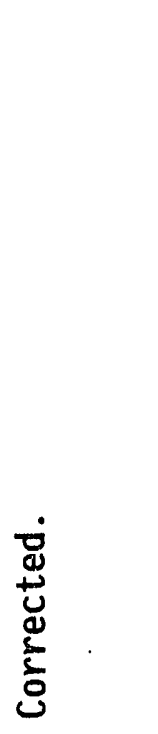 & 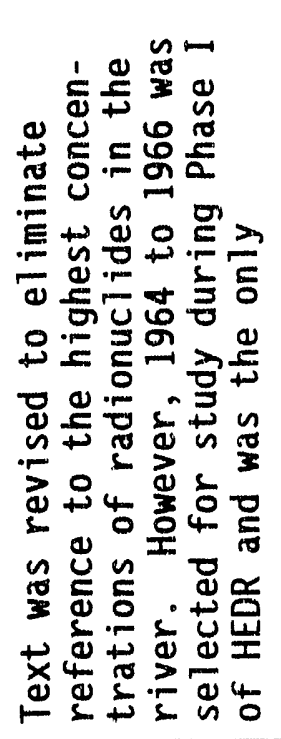 & \\
\hline 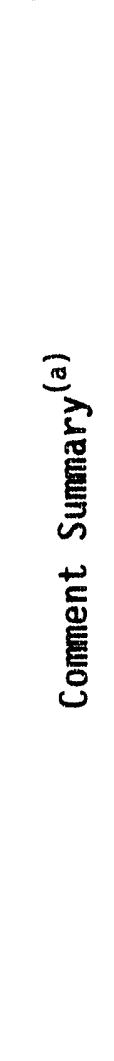 & 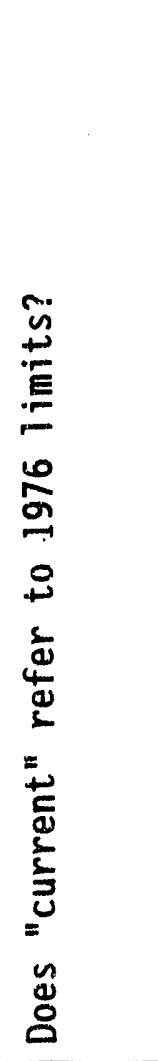 & 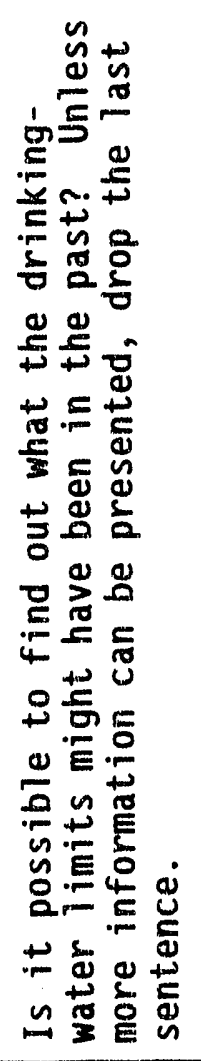 & 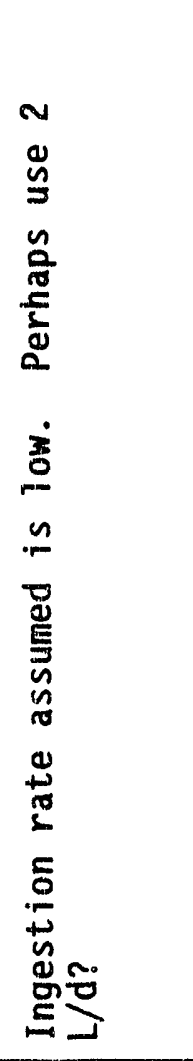 & 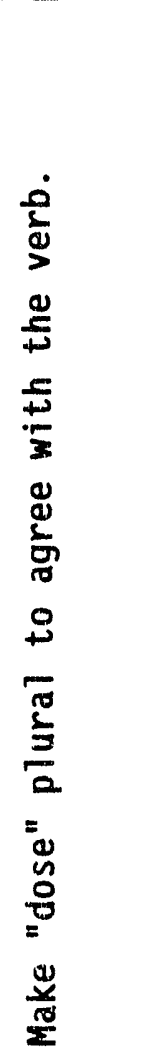 & 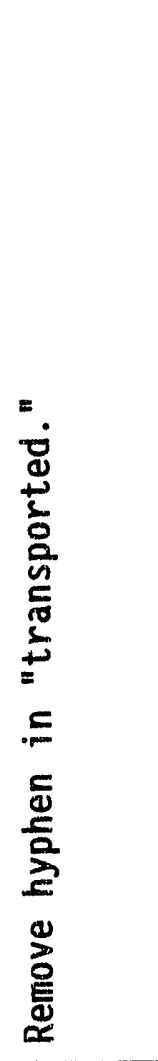 & 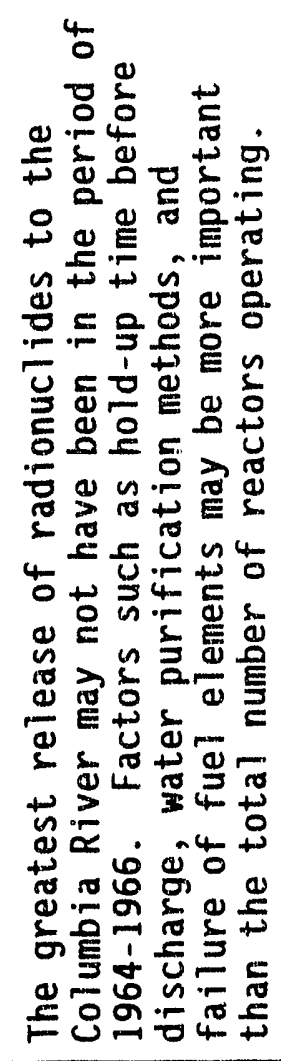 & $\begin{array}{l}\dot{y} \\
\dot{\vec{n}} \\
\dot{a} \\
\dot{z} \\
\dot{v}\end{array}$ \\
\hline 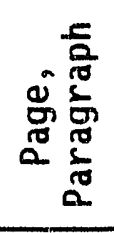 & 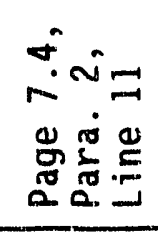 & 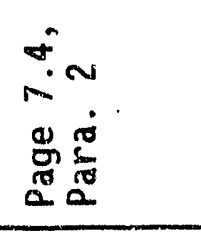 & 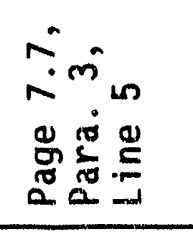 & 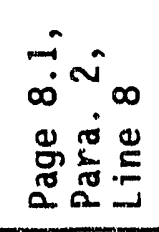 & 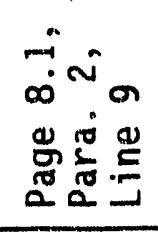 & 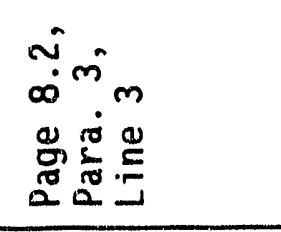 & 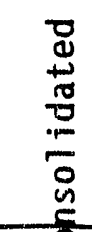 \\
\hline 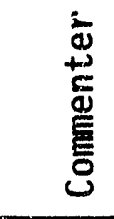 & 号 & 窂 & $\frac{\frac{\alpha}{2}}{2}$ & $\ddot{a}$ & 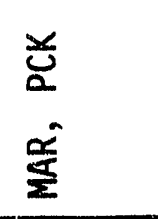 & $\frac{a}{\frac{1}{2}}$ & 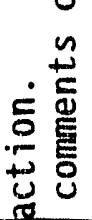 \\
\hline 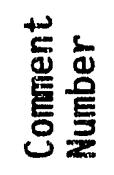 & $\approx$ & $m$ & $\stackrel{\nabla}{\pi}$ & 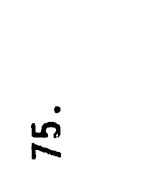 & I0 & $\Sigma$ & $\begin{array}{l}\text { 운 } \\
1 \\
\vdots 00\end{array}$ \\
\hline
\end{tabular}




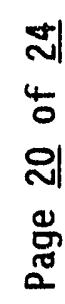

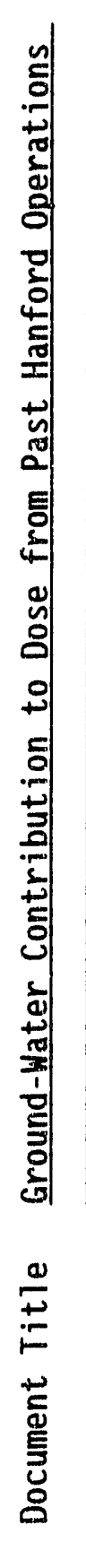

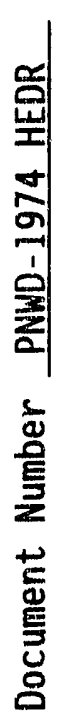

\begin{tabular}{|c|c|c|c|c|c|}
\hline 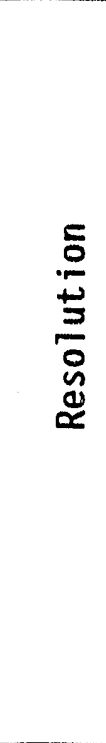 & 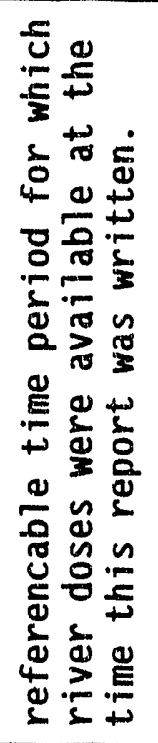 & 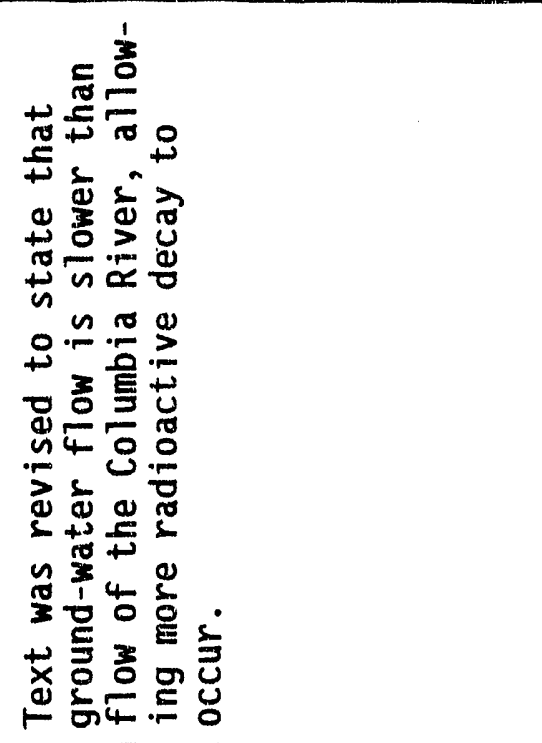 & 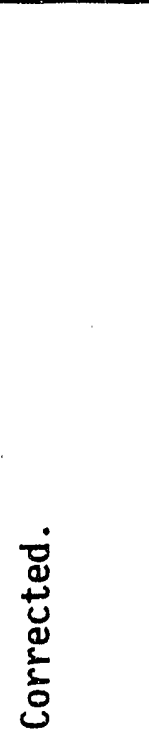 & 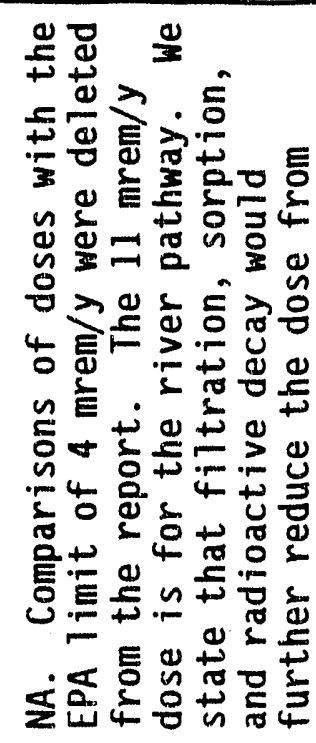 & \\
\hline 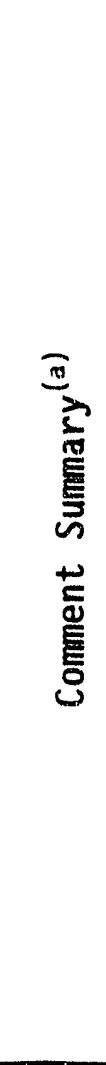 & & 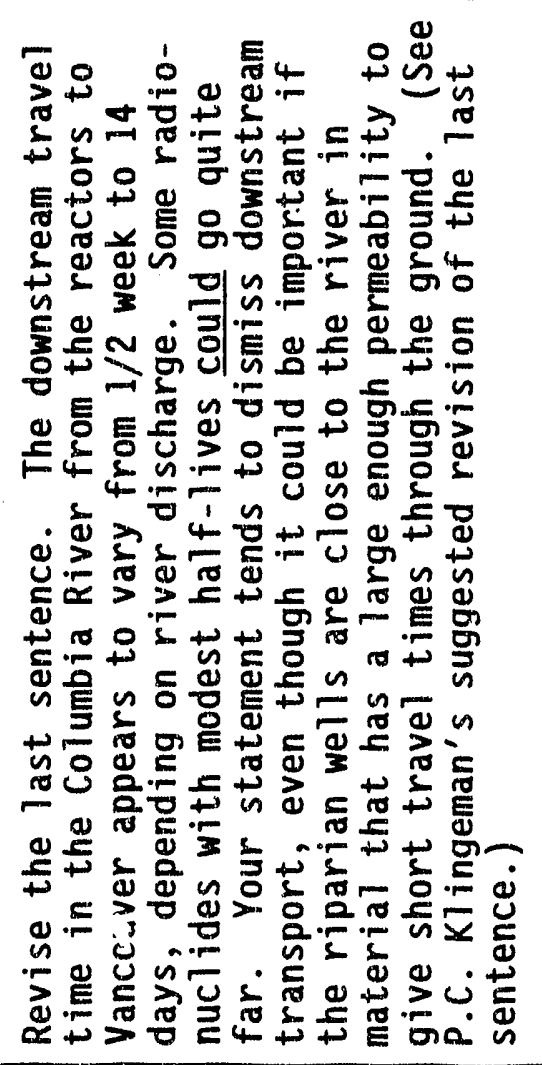 & 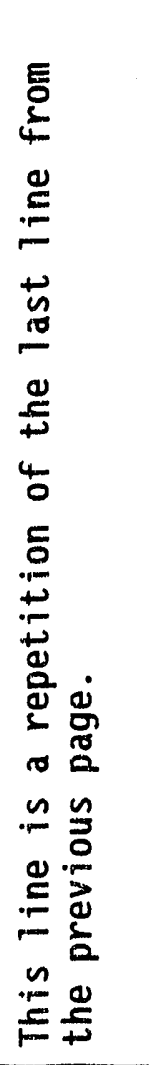 & 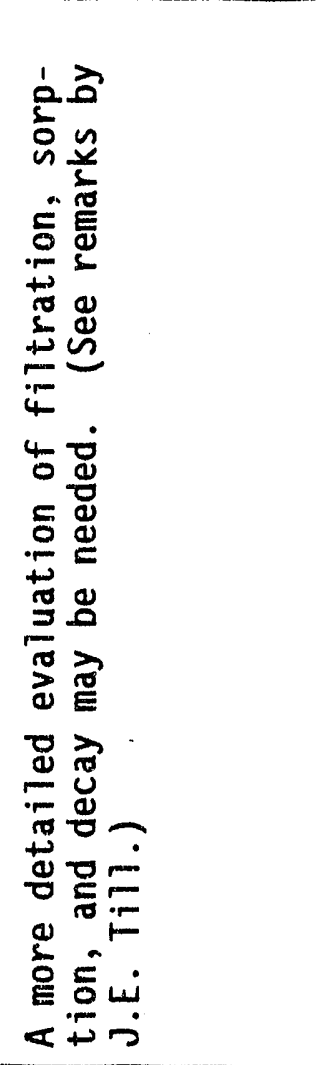 & $\begin{array}{l}\dot{\sim} \\
\dot{\pi} \\
\stackrel{0}{0} \\
\dot{z} \\
\dot{\text { s }}\end{array}$ \\
\hline 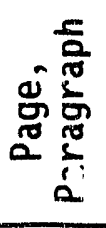 & & 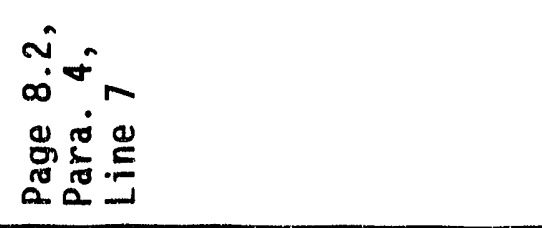 & 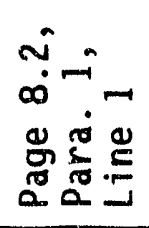 & 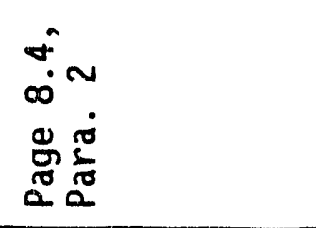 & 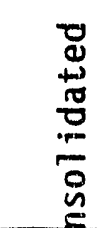 \\
\hline 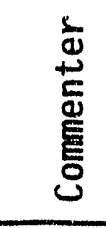 & & 弟 & $\bar{a}$ & 岇 & 莣 \\
\hline 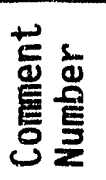 & & $\stackrel{\infty}{\sim}$ & $\pi$ & ంీ & 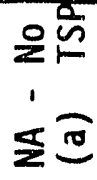 \\
\hline
\end{tabular}




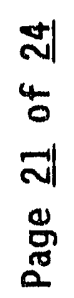

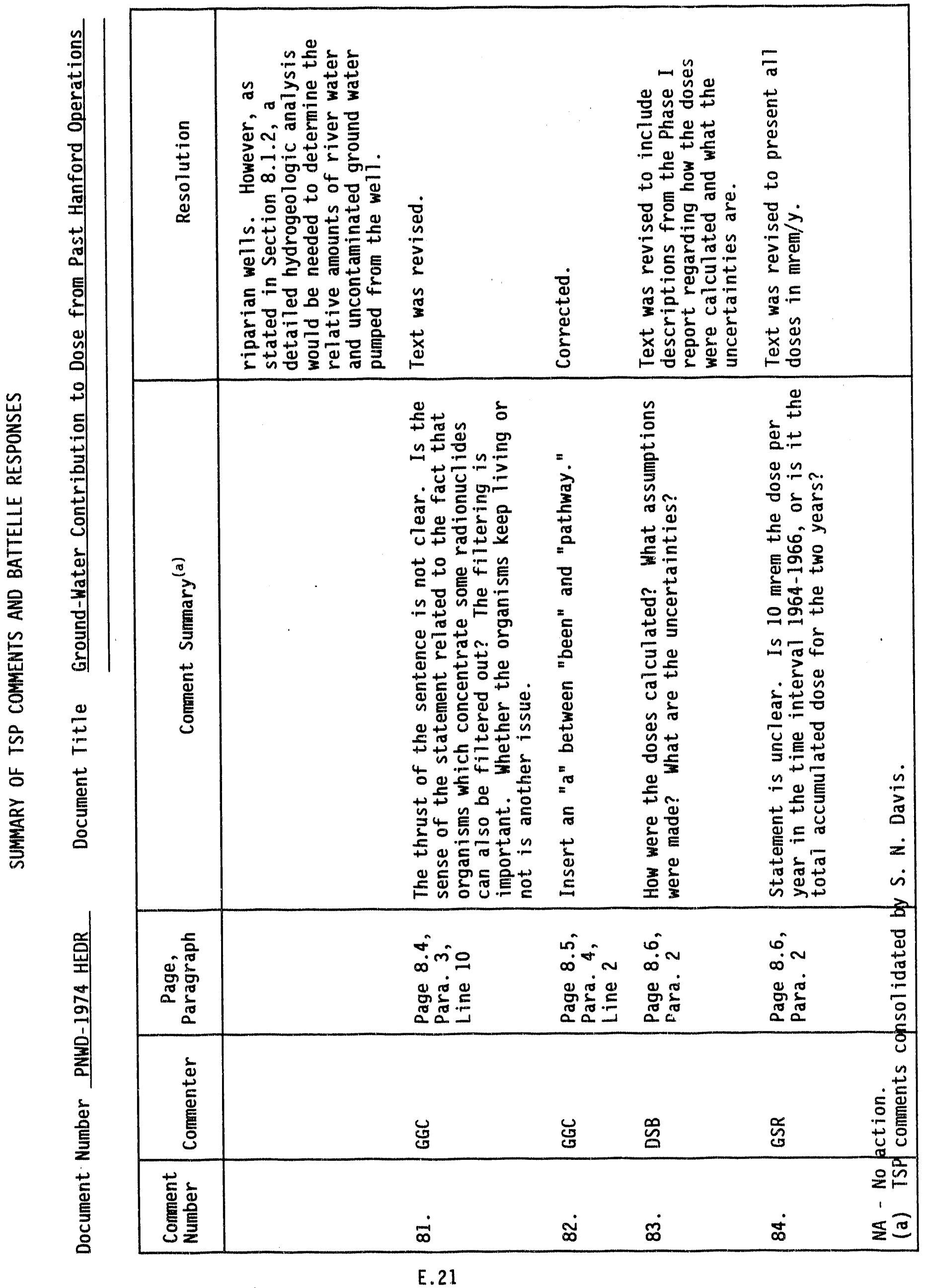




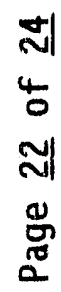

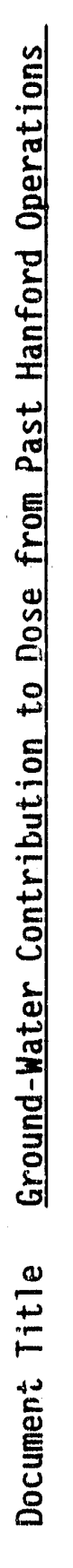

\begin{tabular}{|c|c|c|c|c|c|c|}
\hline 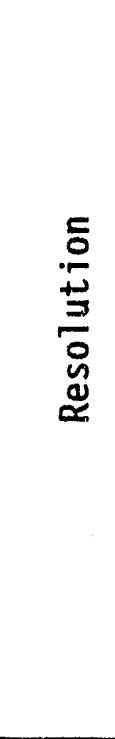 & 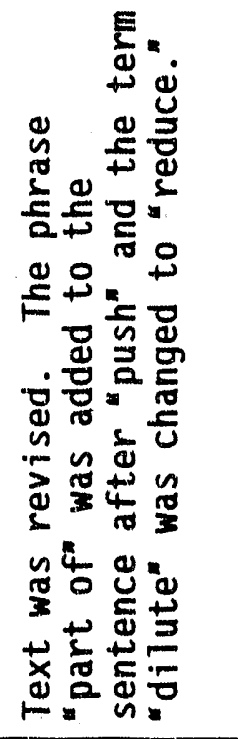 & 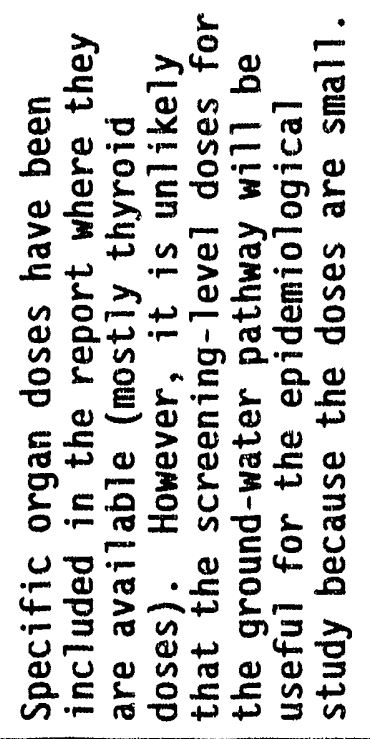 & 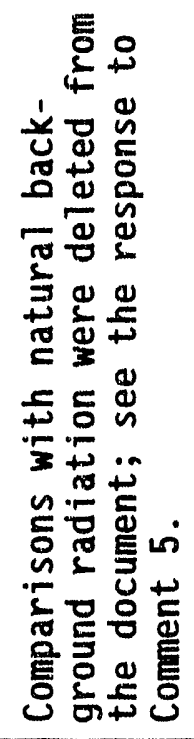 & 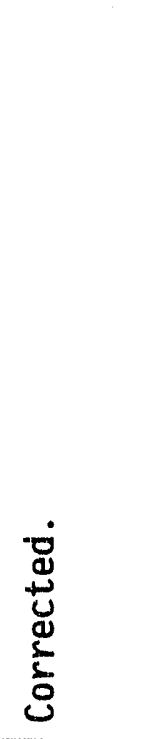 & 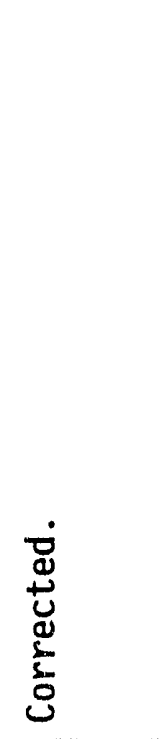 & \\
\hline 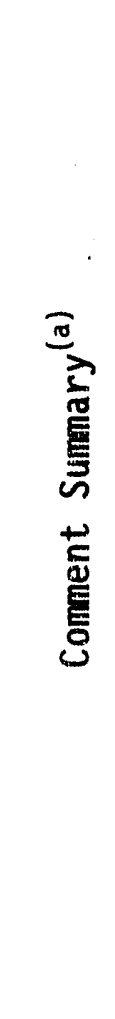 & 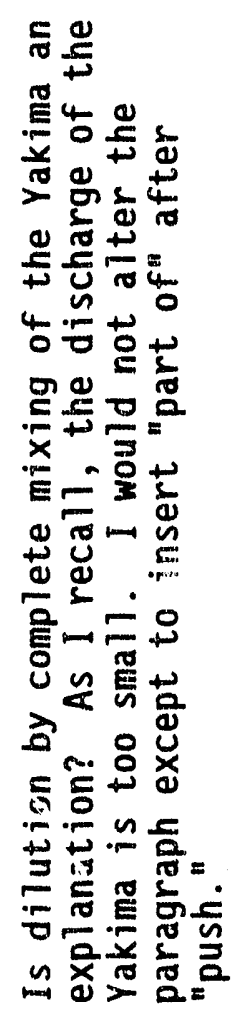 & 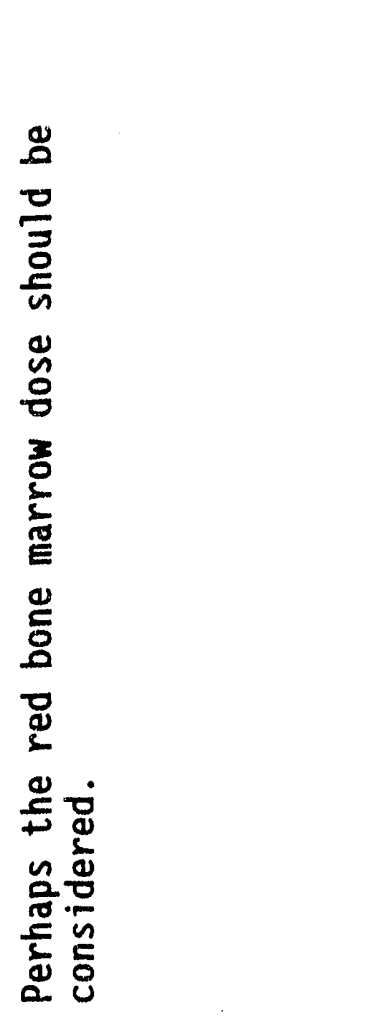 & 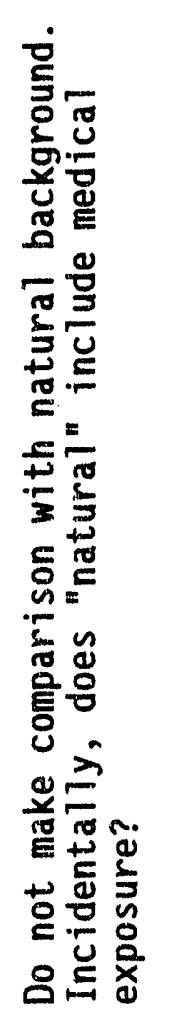 & 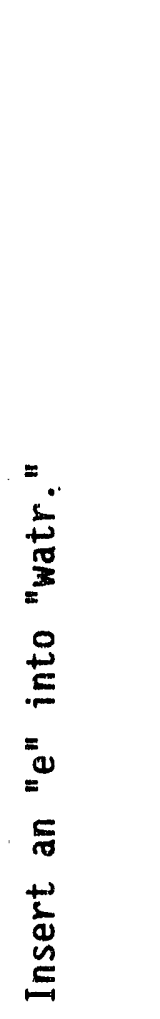 & 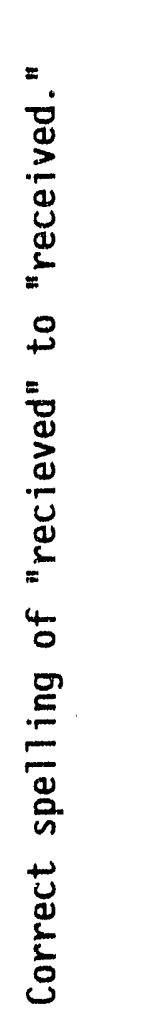 & 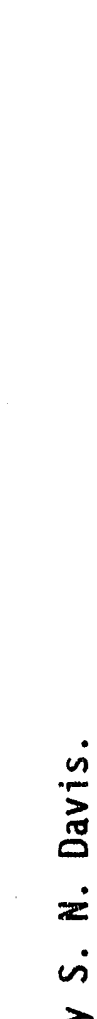 \\
\hline 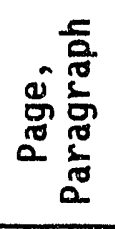 & 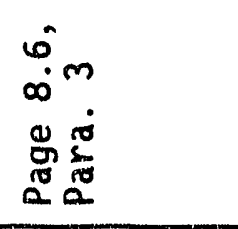 & 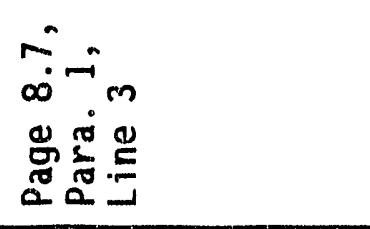 & 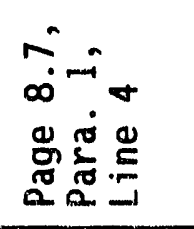 & 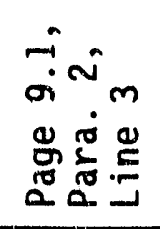 & 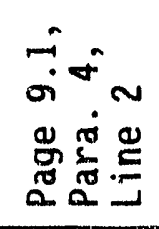 & 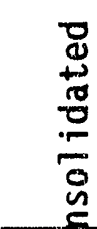 \\
\hline 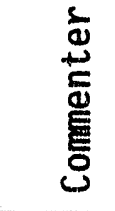 & 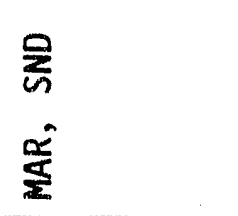 & $\begin{array}{l}\tilde{\omega} \\
\hat{\alpha} \\
\frac{\alpha}{2}\end{array}$ & $\begin{array}{l}\text { 惫 } \\
\text { 空 }\end{array}$ & 总 & 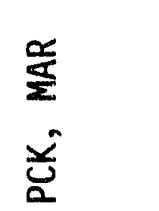 & 总 \\
\hline 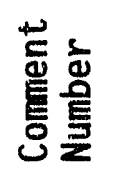 & $\stackrel{L}{\infty}$ & $\mathscr{\infty}$ & $\infty$ & $\stackrel{\infty}{\infty}$ & ळి & $\begin{array}{l}\frac{\tilde{n}}{\llcorner} \\
\dot{5} \Xi\end{array}$ \\
\hline
\end{tabular}




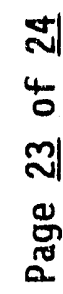
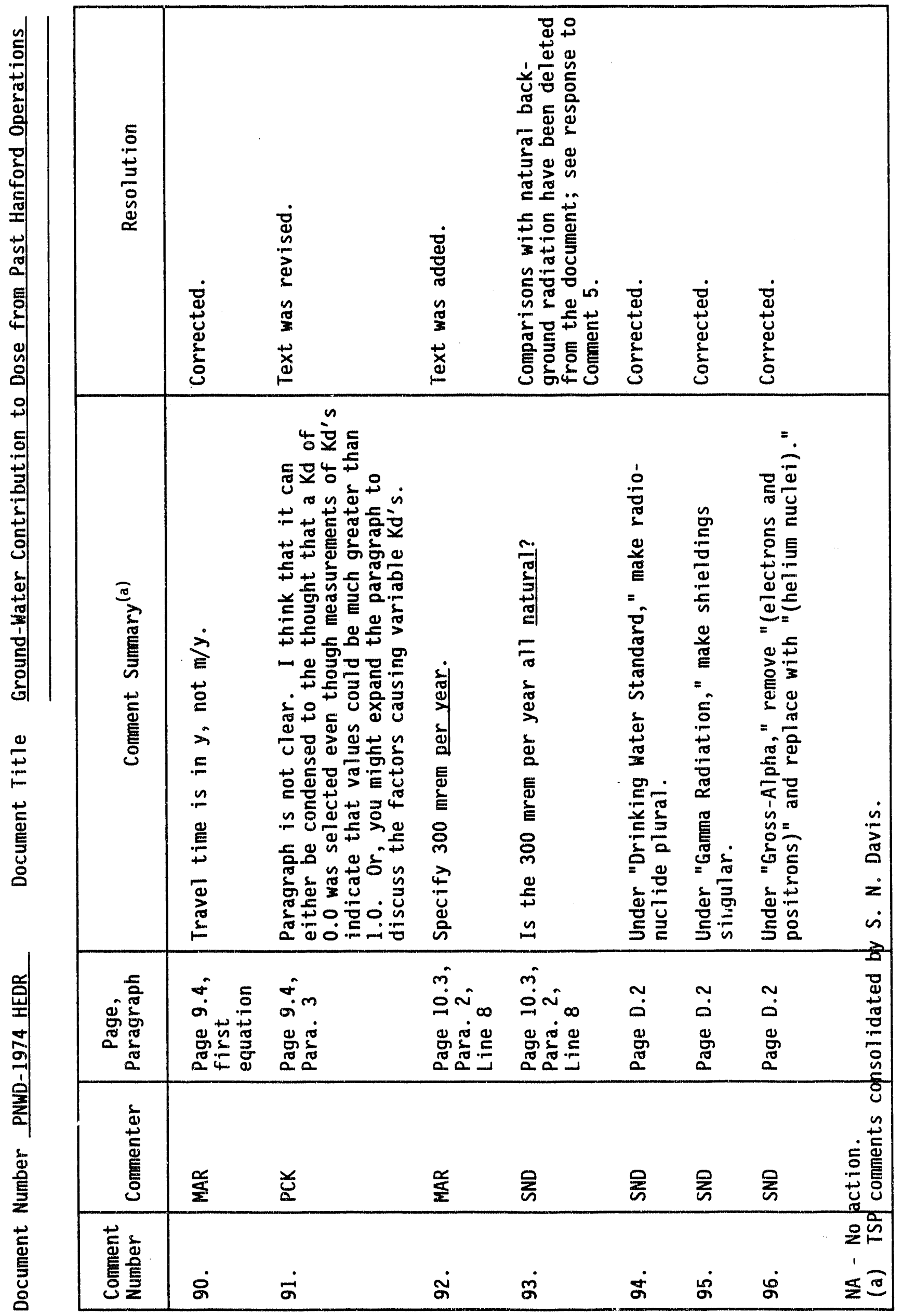

E. 23 


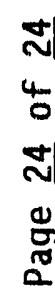

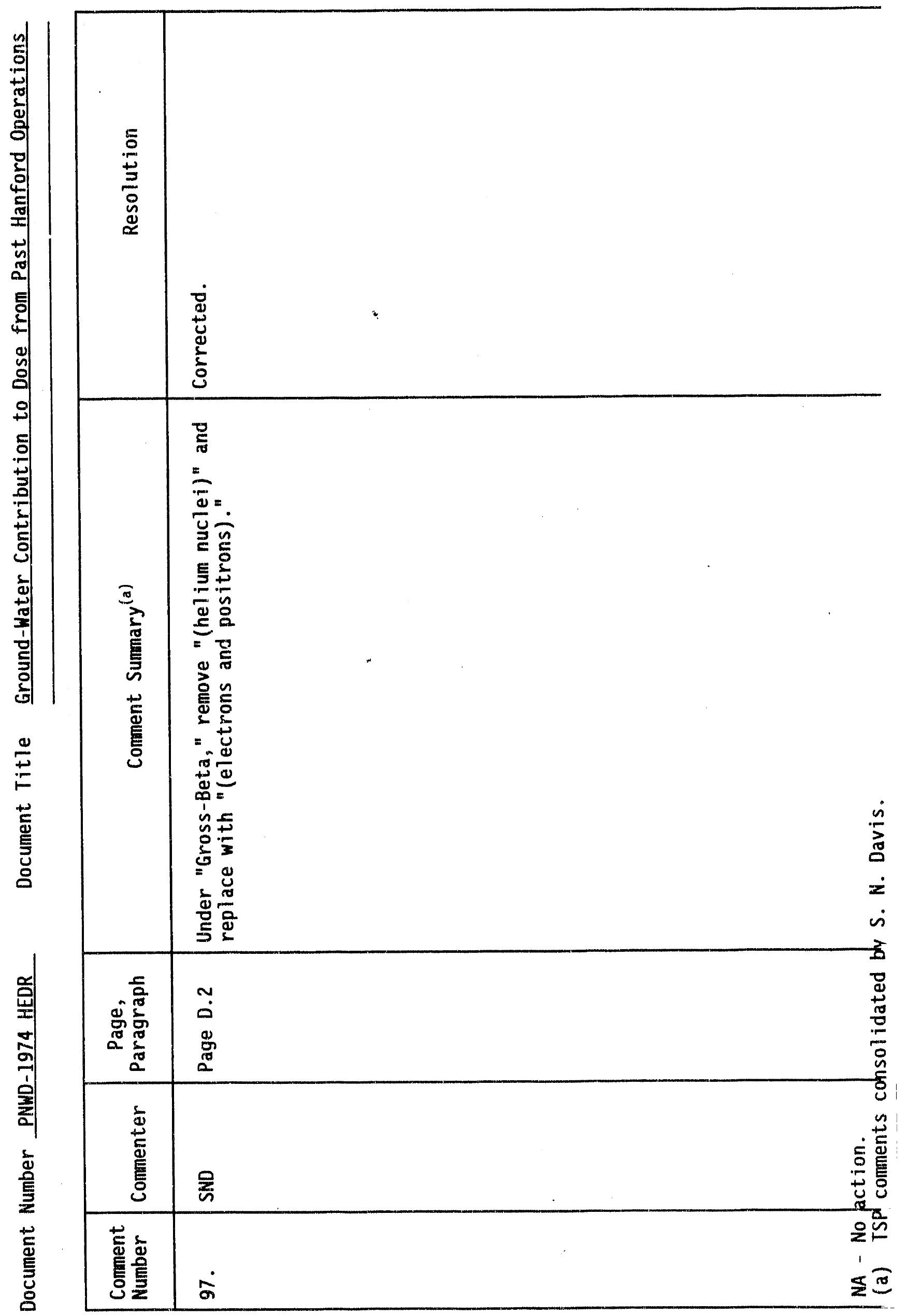


DISTRIBUTION

No. of

Copies

\section{OFFSITE}

Technical Steering Panel

D. S. Barth

University of Nevadi

4505 Maryland Parkway

Las Vegas, NV 89154

W. A. Bishop

2503 Wedgewood Court S.E.

Olympia, WA 98501

M. L. Blazek

Oregon Department of Energy

625 Marion Street N.E.

Salem, OR 97310

G. G. Caldwell

Director

Tulsa City-County Health Dept.

4616 East 15th Street

Tulsa, OK 74112

S. N. Davis

Dept. of Hydrology and Water Resources

Bullding II

Univer sity of Arizona

Tucson, AZ 85721

11. 3. Germond

224 Iron Mountain B1vd.

Lake Oswego, OR 97034

P. C. Klingeman

Civil Engineering Dept.

Appejin Hall 202

Oregon State University

Corvallis, OR 97331-2302
No. of

Copies

K. J. Kopecky

Fred Hutchinson Cancer

Research Center

1124 Columbia Street

Seattle, WA 98104

P. D. McGavran

Dept. of Health and Welfare

450 W. State Street, 4th Floor

Boise, ID 83720-5450

R. L. Morrill

Dept. of Geography, DP-10

University of Washington

Seattle, WA 98195

A. H. Murphy

Dept. of Atmospheric Sciences

Oregon State University

Corvallis, OR 97331-2209

D. W. Price

Agricultural Economics

Hulbert Hall Room 211

Washington State University

Pullman, WA 99164-6210

M. A. Robkin

Radiological Sciences, SB-75

University of Washington

Seattle, WA 98195

G. S. Roessler

Route 1 Box $139 \mathrm{H}$

Elysian, MN 56028

B. Shleien

2421 Homestead Drive

Silver Springs, MD 20902 
No. of

Copies

A. P. Slickpoo, Sr. 809 Nez Perce Lane

P.0. Box 331

Kamiah, ID 83536

J. E. Ti11

Route 2 Box 122

Neeses, SC 29107

D. E. Walker, Jr.

P.0. Box 4147

Boulder, CO 80306

other

2 DOE Office of Scientific and Technical Information

Technical Information Center

P.0. Box 62

Oak Ridge, TN 37830

B. G. Brooks, EH-421

Department of Energy

Room J-112

Germantown, MD 20545

18 K. Charlee

Office of Nuclear Waste Mgmt.

Department of Ecology

719 Sleater Kinney Road, S.E.

Suite 200

Olympia, WA 98504

M. R. Donnelly

Public Health Service

Centers for Disease Control

2201 Sixth Ave.

Mai1 Stop RX-22

Seattle, WA 98121
No. of

Copies

A. W. Conklin

Division of Radiation Protection

Washington State Department of Health

Airindustrial Center

Building 5

LF -13

Olympia, WA 98504

J. L. Erickson

Division of Radiation Protection

Washington State Department of Health

Airindustrial Center

Building 5

LE-13

OTympia, WA 98504

\section{E. Sewell}

Centers for Disease Control

$1600 \mathrm{Cl}$ ifton Road

Atlanta, GA 30333

D. R. Sherwood

Environmental Protection Agency

Region $X$

Richland, WA 99352

J. Thomas

HEAL

1720 N. Ash

Spokane, WA 99205 
No. of

Copies

ONSITE

\section{DOE Richland Field Office}
R. F. Brich, TSD
A5-55
R. E. Gerton
A4-02
R. D. Izatt
A5- 15
M. W. Tiernan
A5-55
Public Reading Room (5) Al-65

3 Westinghouse Hanford Company
G. D. Carpenter
B2-16
R. E. Lerch
B2 - 35
H. E. McGuire
B3 -63

44 Battelle Pacific Northwest Laboratories
M. P. Dergeron
K6-77
R. W. Bryce
K6-96
S. D. Cannon
K1-25
J. M. Daer (5)
D. H. Denham
K1-25
P. G. Doctor
W. T. Farris
M. D. Freshley (5)
R. 0. Gilbert
W. A. Glass
$\mathrm{K} 6-15$
K6-96
K3-54
K6-77
K7 -34
K4-13

No. of

Copies
K1-33

K1-77

K6-42

K3-54

K6-77

K6-96

$\mathrm{K} 1-25$

K3-54

$\mathrm{K} 6-03$

K $6-77$

$\mathrm{K} 1-25$

K7 -34

$\mathrm{K} 6-91$

K1-30

K6-96

K6- 09

K6-54

K1-06

K3-70

P8-55

Routing
R. M. Ecker
J. W. Falco
M. J. Graham
P. M. Irving
R. L. Skaggs
P. C. Hays (last)
MSL/Sequim
K6-78
K6-80
K6-96
K6-77
$\mathrm{K} 6-86$ 

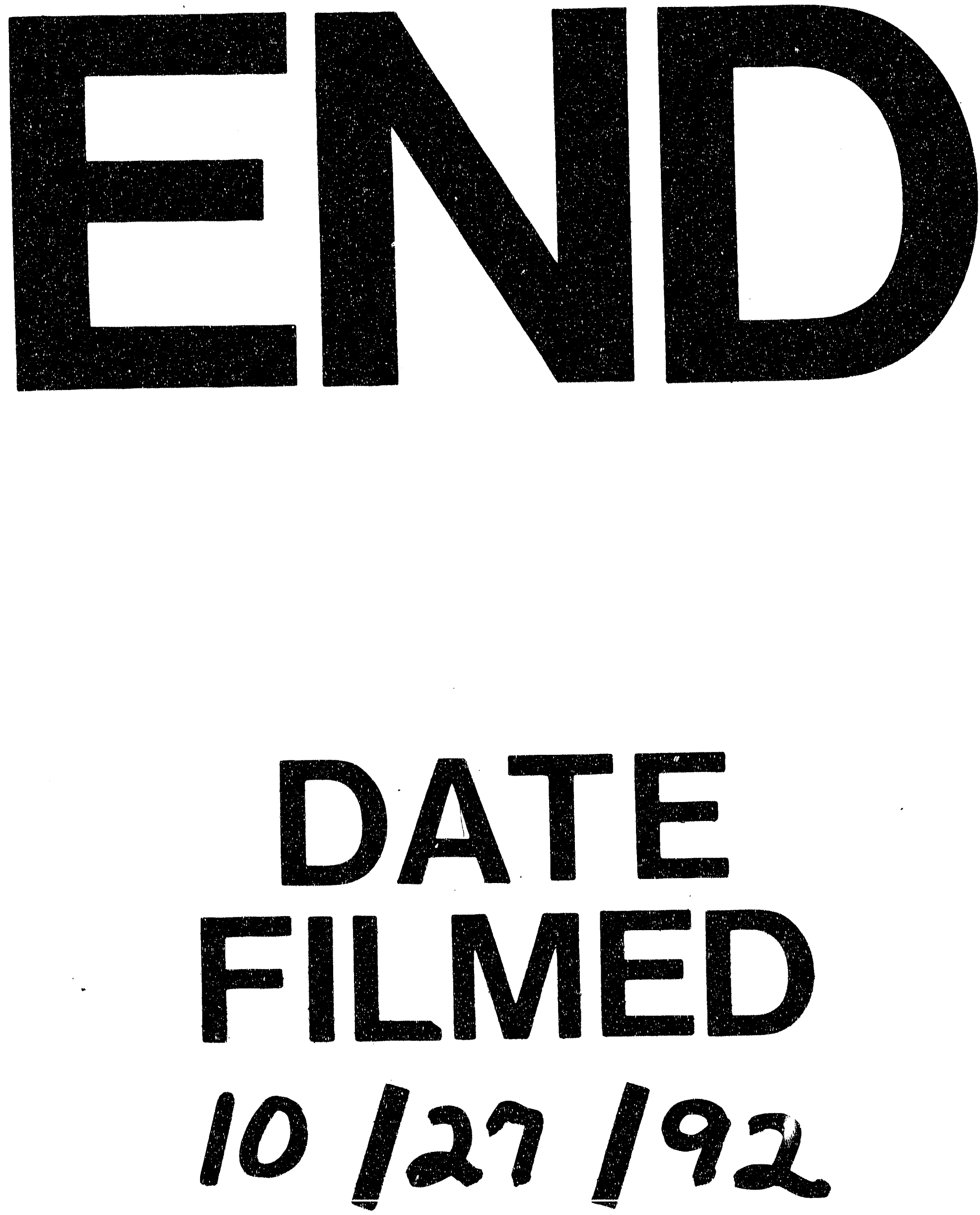
